Serviço de Pós-Gradução EESC/USP

EXEMPLAF REVISADO

Data de entrada no Serviço:.......................

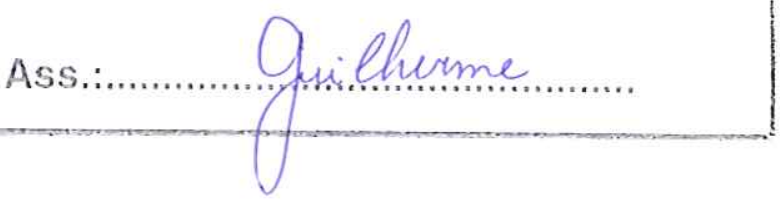

\title{
UMA CONTRIBUIÇÃO AO ESTUDO DO TORNEAMENTO COM ALTA VELOCIDADE
}

\section{Tadeu Tomio Sudo}
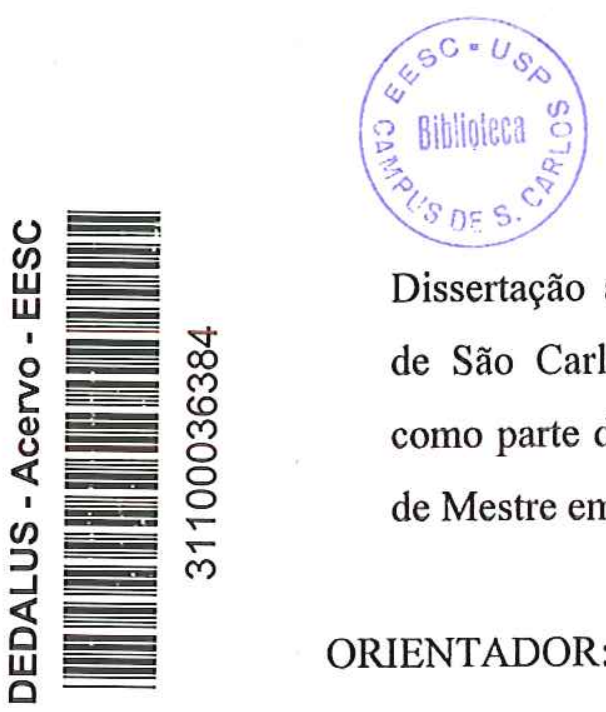

Dissertação apresentada à Escola de Engenharia de São Carlos, da Universidade de São Paulo, como parte dos requisitos para obtenção do título de Mestre em Engenharia Mecânica.

ORIENTADOR: Prof. Dr. Reginaldo Teixeira Coelho

São Carlos 
Candidato: Engenheiro TADEU TOMIO SUDO

Dissertação defendida e aprovada em 08.05.2001 pela Comissão Julgadora:

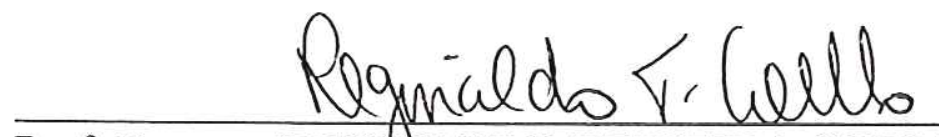

Prof. Doutor REGISALDO TEIXEIRA COELHO (Orientador) (Escola de Engenharia de São Carlos - Universidade de São Paulo)

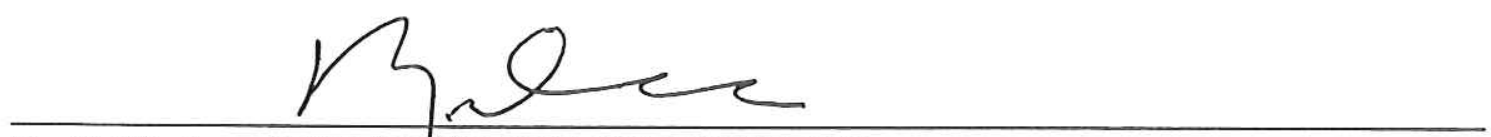

Prof. Titular ROSALVO TIAGO RUFFINO

(Escola de Engqnharia de São Carlos - Universidade de São Paulo)

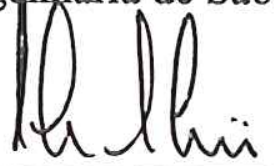

Prof. Doutor KLAUS SCHÜ/TZER

(Universidade Metodista de Piracicaba - UNIMEP)

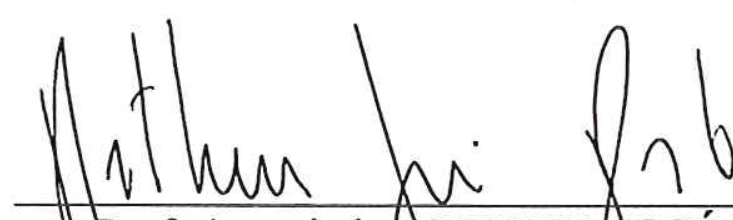

Prof. Associado ARTHUR JOSÉ VIEIRA PORTO

Coordenador do Progranta de Pós-Graduação em Engenharia Mecânica

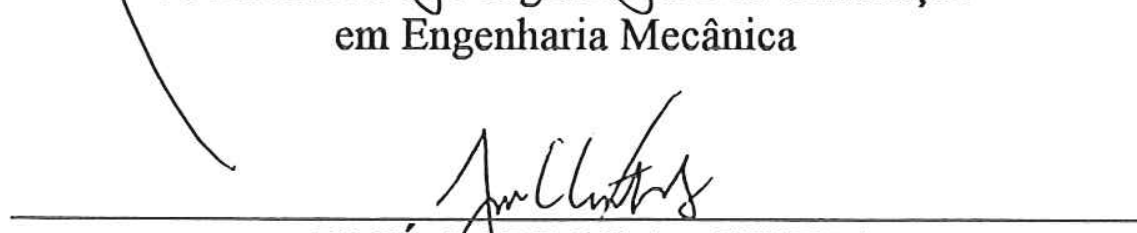

JOSÉ CA RLOS A. CINTRA

Presidente da Conissão de Pós-Graduação da EESC 
Aos meus pais, Yutaka e Yoko À minha noiva, Grace 
Agradecimentos

Ao professor Reginaldo Teixeira Coelho pela excelente orientação, amizade, compreensão e confiança durante a elaboração deste trabalho.

Aos professores João Fernando Gomes de Oliveira, Rosalvo Tiago Ruffino e Luiz Carlos Casteletti pela cooperação na elaboração deste trabalho.

Aos amigos do Grupo de Otimização de Processos de Fabricação Aldo, Alexandre, Carlos, "Dinho”, Fábio, Giuliano, Jalon, João Chagas e Leonardo.

À empresa ITW Chemical Products Ltda., pelo aparelho Aplicador AccuLube $^{\circledR}$

À empresa Auto Pira S/A Ind. e Comércio de Peças, pelos volantes fornecidos.

Aos técnicos Ronaldo, Sr. Adão e "Tico" (Departamento de Materiais) pela colaboração e ajuda.

Às secretárias da pós-graduação Ana Paula e Elizabeth, à Irene e demais funcionários da secretária da Engenharia Mecânica pela atenção.

A todos os colegas, professores e funcionários do Departamento de Engenharia Mecânica da EESC-USP pela colaboração.

À Coordenadoria de Aperfeiçoamento de Pessoal de Nível Superior - CAPES, pelo auxílio concedido. 


\section{SUMÁRIO}

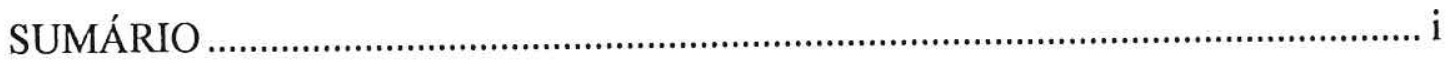

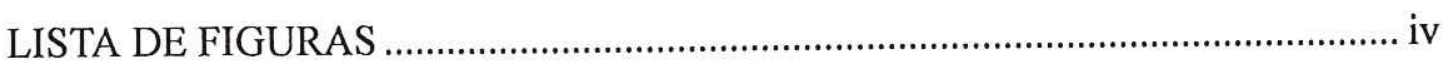

LISTA DE TABELAS .................................................................................... vii

LISTA DE ABREVIATURAS E SIGLAS …........................................................ viii

LISTA DE SÍMBOLOS .................................................................................. ix

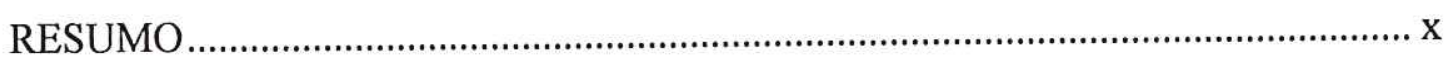

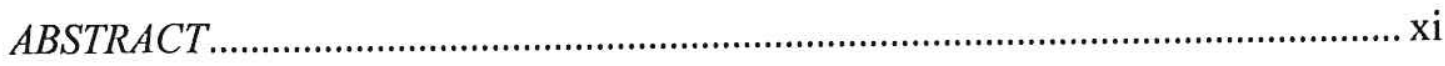

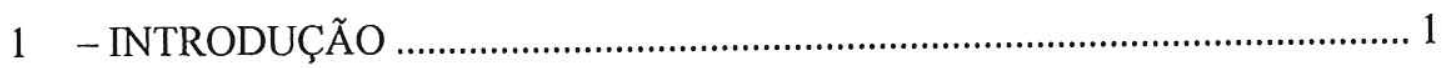

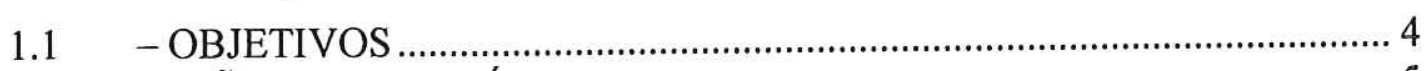

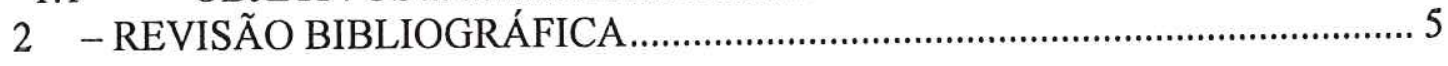

$2.1 \quad$ - FERRO FUNDIDO …..................................................................... 5

2.1.1 - Principais características dos ferros fundidos cinzentos ........................ 7

2.2 - MATERIAIS PARA FERRAMENTAS ................................................. 8

2.2 .1 - Aço Rápido ....................................................................................... 13

2.2.2 - Aço Rápido com Cobertura …............................................................ 14

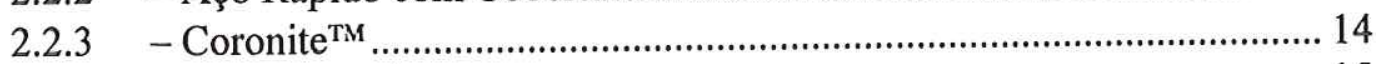

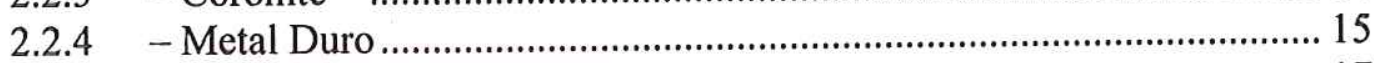

2.2.5 - Metal Duro com Cobertura ................................................................ 17

2.2 .6 - Cermet.......................................................................................... 20

2.2.7 - Material Cerâmico ................................................................................ 22

2.2.8 - Nitreto Cúbico de Boro Policristalino (PCBN) .................................... 28

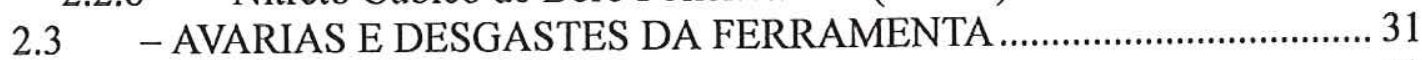

2.3.1 - Temperatura de Corte ....................................................................... 32

2.3.2 - Mecanismos de desgaste da ferramenta .............................................. 34

2.3.3 - Tipos de avarias e desgastes da ferramenta ........................................ 38

2.3.4 - Medição dos desgastes da ferramenta................................................ 41

2.4 -DESGASTE E VIDA DA FERRAMENTA ............................................. 42

2.4.1 - Rugosidade Superficial da peça usinada .............................................. 43

2.5 - USINAGEM COM ALTA VELOCIDADE ...........................................4 45

2.6 - USINABILIDADE DE FERRO FUNDIDO .........................................47

2.6.1 - Usinabilidade ................................................................................. 47

2.6.2 - Usinabilidade de Ferro Fundido Cinzento ........................................ 48

2.6.2.1 - Metal Duro ........................................................................ 51

2.6.2.2 - Metal Duro com Cobertura .................................................... 51

2.6.2.3 - Cermet........................................................................ 51

2.6.2.4 - Material Cerâmico ……........................................................ 52

2.6.2.5 - Nitreto Cúbico de Boro Policristalino (PCBN) ....................... 56

2.7 - FLUIDOS DE CORTE ....................................................................... 57

2.7.1 - Efeitos biológicos e outras desvantagens dos fluidos de corte líquidos. 
2.7.2 - Outros sistemas de refrigeração/lubrificação...................................... 62

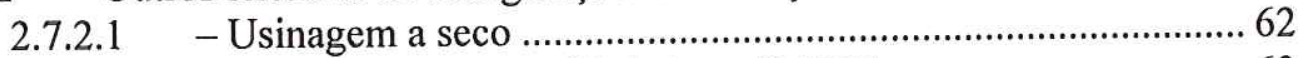

2.7.2.2 - Minimal Quantity of Lubricant (MQL)................................... 63

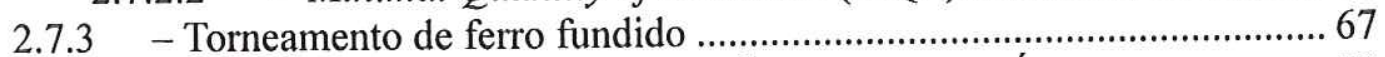

2.8 - TÓPICOS PRINCIPAIS DA REVISÃO BIBLIOGRÁFICA ................... 70

3 - TRABALHO EXPERIMENTAL .................................................................. 71

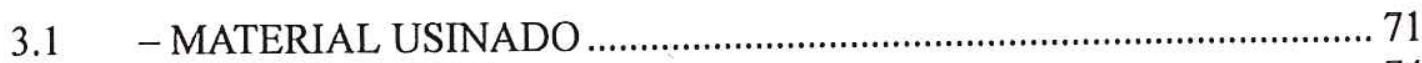

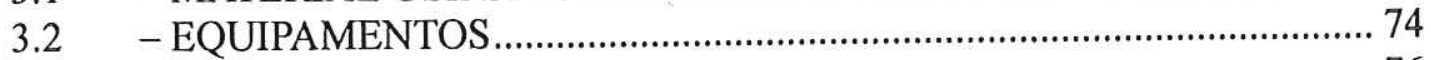

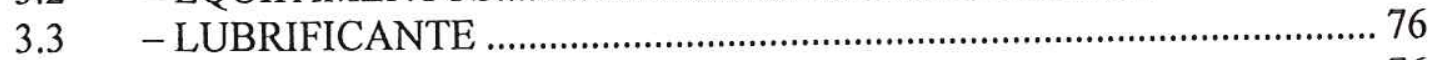

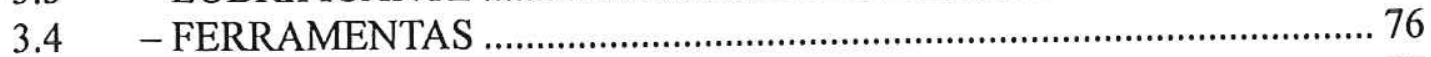

3.4.1 - Insertos de Cerâmica........................................................................... 77

3.4.2 - Insertos de Metal Duro...................................................................... 78

3.5 - PORTA FERRAMENTAS .................................................................... 79

3.6 - PLANEJAMENTO e PROCEDIMENTO EXPERIMENTAL …............. 79

3.6.1 - Preparação do corpo de prova............................................................. 79

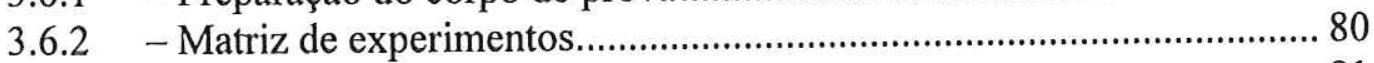

3.6.3 - Montagem da Banca de Ensaios .......................................................... 81

3.6.3.1 - Montagem do equipamento de MQL ..................................... 81

3.6.4 - Medição do desgaste de flanco dos insertos ........................................ 83

3.6.5 - Medição da rugosidade superficial ..................................................... 83

3.6.6 - Preparação dos insertos para análise no microscópio eletrônico de

varredura (SEM) ........................................................................................ 85

3.6.7 - Preparação das amostras para análise de microestrutura do material

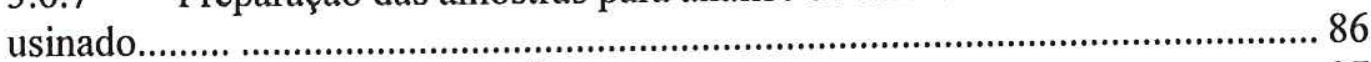

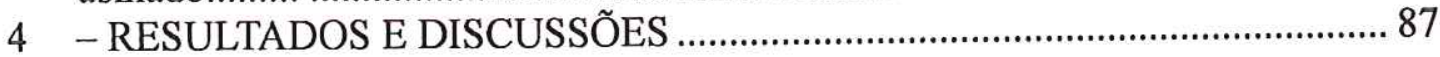

4.1 - RESULTADOS DE DESGASTE DOS INSERTOS E RUGOSIDADE SUPERFICIAL DO MATERIAL USINADO ….................................................... 87

4.1.1 - Investigação do efeito da velocidade de corte usando-se insertos de metal duro

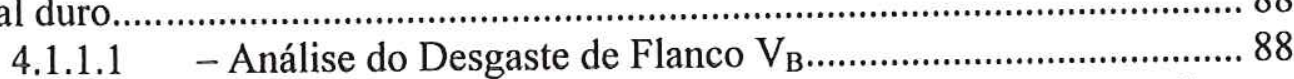

4.1.1.2 - Relação entre Desgaste de Flanco Médio $V_{B}$ e Desgaste de

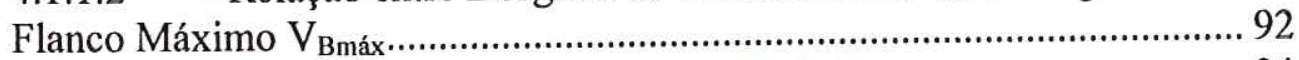

4.1.1.3 - Análise da Rugosidade Superficial Ra................................... 94

4.1.1.4 - Curva de Desgaste do inserto de metal duro em função da velocidade de corte ........................................................................................ 96

4.1.2 - Investigação do efeito do avanço f no desgaste de insertos de

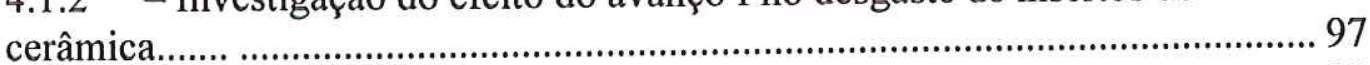

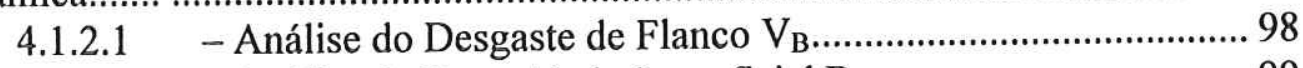

4.1.2.2 - Análise da Rugosidade Superficial Ra................................... 99

4.1.3 - Investigação do efeito da vazão de óleo e de ar na lubrificação MQL99

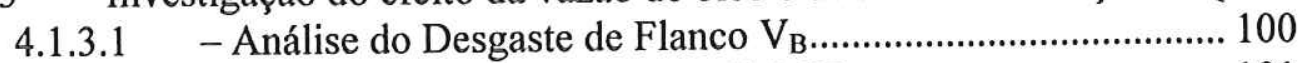

4.1.3.2 - Análise da Rugosidade Superficial Ra................................. 101

4.1.4 - Resumo dos resultados de desgaste de flanco................................... 101

4.1.5 - Resumo dos resultados de rugosidade superficial Ra ....................... 102

4.2 - ANÁLISE DE DESGASTE DOS INSERTOS ...................................... 102

4.2.1 - Metal Duro (velocidade de corte $1000 \mathrm{~m} / \mathrm{min}$ e avanço 0,08 $\mathrm{mm} /$ volta) 
4.2.2 - Metal Duro (velocidade de corte $1350 \mathrm{~m} / \mathrm{min}$ e avanço 0,08 $\mathrm{mm} /$ volta).

4.2.3 - Metal Duro e Cerâmica (velocidade de corte $1700 \mathrm{~m} / \mathrm{min}$ e avanço

$0,08 \mathrm{~mm} /$ volta) 105

4.2.4 - Cerâmica (velocidade de corte $1700 \mathrm{~m} / \mathrm{min}$ e avanço 0,10 $\mathrm{mm} /$ volta). 108

4.2.5 - Resumo sobre a análise de desgaste................................................111

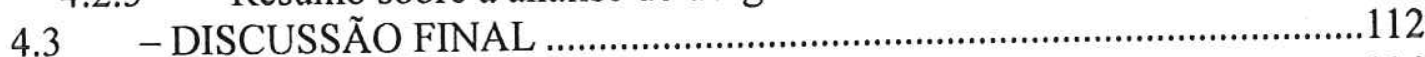

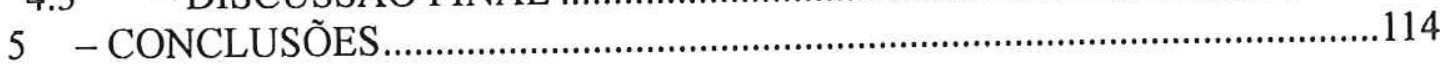

6 - SUGESTÕES PARA TRABALHOS FUTUROS.........................................115

ANEXO A - Principais características dos ferros fundidos ......................................116

ANEXO B - Principais características dos fluidos de corte.....................................119

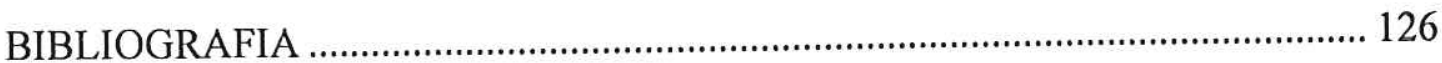

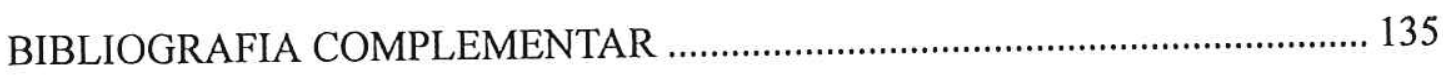

APÊNDICE I - Vantagens e desvantagens dos processos CVD e PVD................... 136

APÊNDICE II - Cálculo teórico da rugosidade Ra ideal ........................................ 137

APÊNDICE III - Dimensões do Volante .................................................................. 139

APÊNDICE IV - Programa CNC .................................................................... 140

APÊNDICE V - Dimensões dos insertos e porta ferramentas ................................ 141

APÊNDICE VI - Conversão de L $f$ para L $c$............................................................. 142

APÊNDICE VII - DADOS DO FABRICANTE DOS VOLANTES........................ 144 


\section{LISTA DE FIGURAS}

Figura 1 - Seleção adequada de ferramenta de corte (KATBI, 1996) ......................... 10

Figura 2 - Superfícies típicas de desgaste (KENDALL, 1989)................................ 32

Figura 3 - Distribuição de temperatura na ponta de uma ferramenta de metal duro

(DINIZ et al., 1999)

Figura 4 - Alguns dos tipos de avarias e desgastes mais comuns (DINIZ et al., 1999)

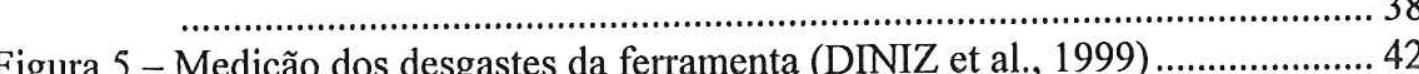

Figura 6 - Variáveis do processo relacionadas com a tecnologia HSM (SCHULZ, 1997)

Figura 7 - Principais propriedades das ferramentas versus condições de usinagem

(KOMANDURI \& SAMANTA, 1989) ................................................ 48

Figura 8 - Aplicações de usinagem de ferro fundido (100 a $300 \mathrm{HB}$ ). Sialon II é produto da Kennametal Inc. (KOMANDURI \& SAMANTA, 1989)....... 50

Figura 9 - Efeitos da estrutura $\mathrm{em}_{\mathrm{c}}$ de torneamento de ferro fundido cinzento (CHIAVERINI, 1984).

Figura 10 - Efeito de $\mathrm{v}_{\mathrm{c}}$ na vida da ferramenta para $\mathrm{V}_{\mathrm{B}}=0,2 \mathrm{~mm}$ (ferro fundido cinzento). Condições: $f=0,1 \mathrm{~mm} /$ volta e $a_{p}=1,0 \mathrm{~mm}$ (HEATH, 1989)........ 56

Figura 11 - Aplicações de fluido no sistema MQL .................................................. 64

Figura 12 - Diagrama esquemático de um sistema MQL (HEISEL et al., 1998) ..... 65

Figura 13 - Tamanho das partículas geradas no sistema MQL (HEISEL et al., 1998)

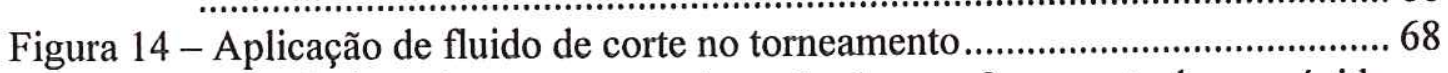

Figura 15 - Distribuição de temperatura da seção de uma ferramenta de aço rápido após usinagem de ferro fundido com $\mathrm{v}_{\mathrm{c}}=183 \mathrm{~m} / \mathrm{min}$ com diferentes aplicações de fluido de corte (TRENT, 1991)

Figura 16-Distribuição de temperatura na superfície de saída da Figura 15 (TRENT, 1991)

Figura 17 - Microestrutura do ferro fundido cinzento GG25, mostrando veios de grafita do tipo A (sem ataque, aumento $100 \mathrm{x}$ ). Exemplo de veios de tamanho $\mathrm{n}^{\circ} 4$.

Figura 18 - Microestrutura de uma matriz perlítica do ferro fundido cinzento GG25, mostrando os constituintes perlita e veios de grafita. Ataque: nital 2\% ... 73

Figura 19 - Aplicador Accu-Lube ${ }^{\circledR}$ de Micro-Lubrificação ........................................ 75

Figura 20 - Dispositivo para fixação do volante na placa do torno............................ 79

Figura 21 - Montagem do ensaio experimental com MQL (1 bocal)......................... 82

Figura 22 - Medição de rugosidade no volante usinado............................................ 84

Figura 23 - Inserto colado em suporte de alumínio para fixação no microscópio eletrônico de varredura ............................................................................. 85

Figura 24 - Gráfico do Desgaste de Flanco $V_{B}$ no torneamento a seco de GG25 com inserto de metal duro

Figura 25 - Gráfico do Desgaste de Flanco $\mathrm{V}_{\mathrm{B}}$ no torneamento com MQL (vazão de óleo $12 \mathrm{ml} / \mathrm{h}$ e vazão de ar $18 \mathrm{~m}^{3} / \mathrm{h}$ ) de GG25 com inserto de metal duro 90

Figura 26-Razão entre $V_{B}$ do torneamento a seco e com MQL (vazão de óleo 12 $\mathrm{ml} / \mathrm{h}$ e vazão de $\operatorname{ar} 18 \mathrm{~m}^{3} / \mathrm{h}$ ) para $\mathrm{v}_{\mathrm{c}} 1700 \mathrm{~m} / \mathrm{min}$ em função do percurso de avanço $\mathrm{L} f$....... 
Figura 27 - Gráfico do Desgaste de Flanco $V_{B}$ no torneamento a seco e com MQL (vazão de óleo $12 \mathrm{ml} / \mathrm{h}$ e vazão de $\operatorname{ar} 18 \mathrm{~m}^{3} / \mathrm{h}$ ) de $\mathrm{GG} 25 \mathrm{com}$ inserto de metal duro

Figura 28 - Gráfico comparativo do Desgaste de Flanco $V_{B}$ e $V_{B \max }$ no torneamento de GG25 com inserto de metal duro com $\mathrm{v}_{\mathrm{c}} 1000 \mathrm{~m} / \mathrm{min}$ (a seco)

Figura 29 - Gráfico comparativo do Desgaste de Flanco $V_{B}$ e $V_{B \max }$ no torneamento de GG25 com inserto de metal duro com $v_{c} 1350 \mathrm{~m} / \mathrm{min}$ (a seco) ........... 93

Figura 30 - Gráfico comparativo do Desgaste de Flanco $V_{B}$ e $V_{B \max }$ no torneamento de GG25 com inserto de metal duro com $\mathrm{v}_{\mathrm{c}} 1700 \mathrm{~m} / \mathrm{min}$ (com MQL: vazão de óleo $12 \mathrm{ml} / \mathrm{h}$ e vazão de $\operatorname{ar} 18 \mathrm{~m}^{3} / \mathrm{h}$ ).

Figura 31 - Gráfico da Rugosidade Superficial Ra no torneamento a seco de GG25 com inserto de metal duro

Figura 32 - Gráfico da Rugosidade Superficial Ra no torneamento com MQL (vazão de óleo $12 \mathrm{ml} / \mathrm{h}$ e vazão de ar $18 \mathrm{~m}^{3} / \mathrm{h}$ ) de GG25 com inserto de metal duro

Figura 33 - Curva de vida do inserto de metal duro em função do desgaste de flanco $\mathrm{V}_{\text {B }}$ para Lf $168 \mathrm{~mm}$ (MQL: vazão de óleo $12 \mathrm{ml} / \mathrm{h}$ e vazão de ar $18 \mathrm{~m}^{3} / \mathrm{h}$ )

Figura 34 - Curva de vida do inserto de metal duro em função da rugosidade superficial Ra para Lf 168 mm (MQL: vazão de óleo $12 \mathrm{ml} / \mathrm{h}$ e vazão de ar $18 \mathrm{~m}^{3} / \mathrm{h}$ ).

Figura 35 - Gráfico do Desgaste de Flanco $V_{B}$ no torneamento de GG25 com inserto de cerâmica com velocidade de corte $1700 \mathrm{~m} / \mathrm{min}$ para diferentes avanços (a seco) 98

Figura 36 - Gráfico da Rugosidade Superficial Ra no torneamento de GG25 com inserto de cerâmica com velocidade de corte $1700 \mathrm{~m} / \mathrm{min}$ para diferentes avanços (a seco)

Figura 37 - Gráfico da influência da vazão de óleo e de ar no Desgaste de Flanco $V_{B}$ no torneamento com MQL de GG25 com inserto de cerâmica

Figura 38 - Gráfico da influência da vazão de óleo e de ar na Rugosidade Superficial no torneamento com MQL de GG25 com inserto de cerâmica

Figura 39 - Inserto de metal duro 3015 desgastado no torneamento a seco de ferro fundido cinzento GG25 ( $\left.\mathrm{v}_{\mathrm{c}} 1000 \mathrm{~m} / \mathrm{min}\right)$

Figura 40 - Inserto de metal duro 3015 desgastado no torneamento a seco de ferro fundido cinzento GG25 ( $\left.\mathrm{v}_{\mathrm{c}} 1350 \mathrm{~m} / \mathrm{min}\right)$

Figura 41 - Inserto de metal duro 3015 desgastado no torneamento com MQL (vazão de óleo $12 \mathrm{ml} / \mathrm{h}$ e vazão de ar $\left.18 \mathrm{~m}^{3} / \mathrm{h}\right)$ de ferro fundido cinzento GG25 ( $\mathrm{v}_{\mathrm{c}}$ $1350 \mathrm{~m} / \mathrm{min}$ )

Figura 42 - Inserto de metal duro 3015 desgastado no torneamento a seco de ferro fundido cinzento GG25 ( $\left.\mathrm{v}_{\mathrm{c}} 1700 \mathrm{~m} / \mathrm{min}\right)$ 106

Figura 43 - Inserto de metal duro 3015 desgastado no torneamento com MQL (vazão de óleo $12 \mathrm{ml} / \mathrm{h}$ e vazão de ar $\left.18 \mathrm{~m}^{3} / \mathrm{h}\right)$ de ferro fundido cinzento GG25 ( $\mathrm{v}_{\mathrm{c}}$ $1700 \mathrm{~m} / \mathrm{min}$ )

Figura 44 - Inserto de cerâmica CC650 desgastado no torneamento a seco de ferro fundido cinzento GG25 ( $\left.\mathrm{v}_{\mathrm{c}} 1700 \mathrm{~m} / \mathrm{min}\right)$

Figura 45 - Inserto de cerâmica CC650 desgastado no torneamento a seco de ferro fundido cinzento GG25 ( $\mathrm{v}_{\mathrm{c}} 1700 \mathrm{~m} / \mathrm{min}$ e avanço $0,10 \mathrm{~mm} /$ volta $) . . . . . .109$ 
Figura 46 - Inserto de cerâmica CC650 desgastado no torneamento de ferro fundido cinzento GG25 (lubrificação MQL: vazão de óleo $10 \mathrm{ml} / \mathrm{h}$ e vazão de ar $\left.9 \mathrm{~m}^{3} / \mathrm{h}\right)\left(\mathrm{v}_{\mathrm{c}} 1700 \mathrm{~m} / \mathrm{min}\right.$ e avanço $0,10 \mathrm{~mm} /$ volta $)$

Figura 47 - Inserto de cerâmica CC650 desgastado no torneamento de ferro fundido cinzento GG25 (lubrificação MQL: vazão de óleo $20 \mathrm{ml} / \mathrm{h}$ e vazão de ar 9 $\left.\mathrm{m}^{3} / \mathrm{h}\right)\left(\mathrm{v}_{\mathrm{c}} 1700 \mathrm{~m} / \mathrm{min}\right.$ e avanço $0,10 \mathrm{~mm} /$ volta $)$.

Figura 48 - Gráfico de Ra em função do avanço (f) e raio de ponta da ferramenta $\left(\mathrm{r}_{\varepsilon}\right)$

Figura 49 - Detalhes do volante de ferro fundido cinzento GG25 utilizado nos ensaios.

Figura 50 - Dimensões do inserto de Cerâmica CC 650 código SNGA 120408 T01020 da Sandvik

Figura 51 - Dimensões do inserto de Metal Duro GC 3015 código SNMA 120408-

KR da Sandvik

Figura 52 - Dimensões do porta ferramentas CSSNL-2525M-12IC da Sandvik.... 141 


\section{LISTA DE TABELAS}

Tabela 1 - Alguns exemplos de materiais cerâmicos (BAUMGARTEN, 1988)....... 23

Tabela 2 - Principais cerâmicas e suas composições e aplicações (MEHROTRA,

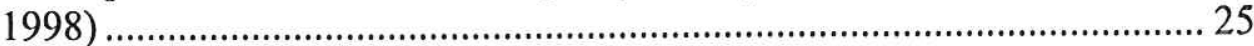

Tabela 3 - Ponto de amolecimento de alguns materiais para ferramenta .................. 34

Tabela 4 - Propriedades mecânicas do ferro fundido cinzento GG25 (DIN 1691)... 74

Tabela 5 - Valores da rugosidade superficial Ra do corpo de prova antes do ensaio 74

Tabela 6 - Condições de usinagem para torneamento de acabamento ....................... 77

Tabela 7 - Condições de usinagem recomendados pelo fabricante do inserto de cerâmica CC650 ........................................................................................... 77

Tabela 8 - Condições de usinagem recomendadas pelo fabricante do inserto de metal

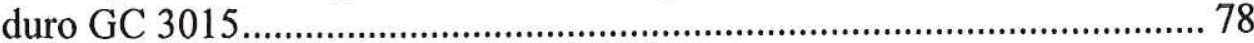

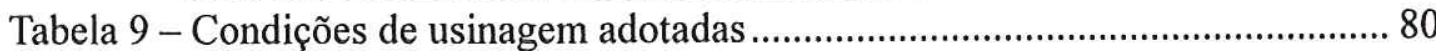

Tabela 10 - Matriz de Experimentos .......................................................................... 81

Tabela 11 - Valores de Ra ideal em função do raio de ponta do inserto e avanço .... 85

Tabela 12 - Comparações entre os insertos utilizados e do fabricante dos volantes 113

Tabela 13 - Vantagens e desvantagens do processo CVD (PEYRE \&

VINTERHOLLER, 1994).................................................................... 136

Tabela 14 - Vantagens e desvantagens do processo PVD (PEYRE \&

VINTERHOLLER, 1994) ....................................................................... 136

Tabela 15 - Tabela de conversão $\mathrm{L} f$ para $\mathrm{L} c$........................................................... 143 


\section{LISTA DE ABREVIATURAS E SIGLAS}

\begin{tabular}{ll} 
ABNT & - Associação Brasileira de Normas Técnicas \\
AFS & - American Foundrymen's Society \\
AISI & - American Iron and Steel Institute \\
ASM & - American Society for Metals \\
ASTM & - American Society for Testing Materials \\
CVD & - Chemical Vapour Deposition \\
DIN & - Deutsches Institut für Normung \\
HSC & - High Speed Cutting \\
HSM & - High Speed Machining \\
ISO & - International Standards Organization \\
MCD & - Monocrystalline Diamond \\
MQL & - Minimal Quantity of Lubricant \\
PA-CVD & - Plasma-Assisted Chemical Vapour Deposition Process \\
PCBN & - Polycrystalline Cubic Boron Nitride \\
PCD & - Polycrystalline Diamond \\
PECVD & - Plasma-Enhanced Chemical Vapour Deposition \\
PVD & - Physical Vapour Deposition \\
RMS & - Root Mean Square Average \\
SAE & - Society of Automotive Engineers \\
UHSM & - Ultra High Speed Machining \\
\hline
\end{tabular}




\section{LISTA DE SÍMBOLOS}

$$
\begin{array}{ll}
\alpha & \text { - Ângulo de Folga (graus) } \\
\gamma & \text { - Ângulo de Saída (graus) } \\
\mathrm{a}_{\mathrm{p}} & \text { - Profundidade ou largura de usinagem (mm) } \\
\mathrm{f} & \text { - Avanço (mm/volta) } \\
\mathrm{HB} & \text { - Dureza Brinell } \\
\mathrm{HRc} & \text { - Dureza Rockwell C } \\
\mathrm{HV} & \text { - Dureza Vickers } \\
\mathrm{KB} & \text { - Largura do desgaste de cratera (mm) } \\
\mathrm{KM} & \text { - Distância do centro da cratera à aresta de corte (mm) } \\
\mathrm{KT} & \text { - Profundidade do desgaste de cratera (mm) } \\
\mathrm{r}_{\varepsilon} & \text { - Raio de ponta da ferramenta (mm) } \\
\mathrm{Ra}_{\mathrm{m}} & \text { - Rugosidade Média Aritmética ( } \mu \mathrm{m}) \\
\mathrm{V}_{\mathrm{B}} & \text { - Largura Média do Desgaste de Flanco (mm) } \\
\mathrm{VB}_{\mathrm{C}} & \text { - Desgaste de Entalhe na superfície de folga (mm) } \\
\mathrm{V}_{\mathrm{Bmax}} & \text { - Largura Máxima do Desgaste de Flanco (mm) } \\
\mathrm{VB}_{\mathrm{N}} & \text { - Desgaste de Entalhe na superfície de folga (mm) } \\
\mathrm{V}_{\mathrm{c}} & \text { - Velocidade de Corte (m/min) }
\end{array}
$$




\section{RESUMO}

SUDO, T.T. (2001). Uma contribuição ao estudo do torneamento com alta velocidade. São Carlos, 2001. 144p. Dissertação (Mestrado) - Escola de Engenharia de São Carlos, Universidade de São Paulo.

O material metálico ferro fundido cinzento é muito utilizado industrialmente, principalmente na área automobilística. Usinagem com alta velocidade tem sido uma tendência atual para aumentar a produtividade, com a possibilidade de se obter ótima qualidade superficial, possivelmente eliminando processos subseqüentes. Aliado à questão de qualidade ambiental, as operações de usinagem têm-se voltado para usinagem a seco ou com mínima quantidade de lubrificante (MQL - minimal quantity of lubricant). Este trabalho estuda o torneamento com alta velocidade de ferro fundido cinzento GG25 através de usinagem a seco e com MQL. Utiliza-se, em operação de faceamento, ferramenta de cerâmica mista $\left(\mathrm{Al}_{2} \mathrm{O}_{3}+\mathrm{TiC}\right)$ e metal duro com cobertura $\left(\mathrm{TiCN} / \mathrm{Al}_{2} \mathrm{O}_{3} / \mathrm{TiN}\right)$, usando velocidades de corte muito acima dos valores tradicionais. Comparativamente o desgaste é significativamente menor na cerâmica. O tipo de desgaste predominante é o desgaste de flanco. Os principais mecanismos de desgaste encontrados são abrasão mecânica e delaminação. O aumento do avanço diminui o desgaste de flanco. Existe uma razão entre a vazão de óleo e a vazão de ar na lubrificação MQL que viabiliza sua aplicação com relação ao desgaste de flanco. Em todas as condições testadas, o sistema MQL mostra ser capaz de reduzir a rugosidade superficial $\mathrm{Ra}$.

Palavras-chave: ferro fundido cinzento; GG25; cerâmica; metal duro; usinagem a seco; MQL; usinagem com alta velocidade; torneamento com alta velocidade. 


\section{ABSTRACT}

SUDO, T.T. (2001). A contribution to the study of high speed turning. São Carlos, 2001. 144p. Dissertação (Mestrado) - Escola de Engenharia de São Carlos, Universidade de São Paulo.

The gray cast iron material is very used industrially, mainly in the automotive industry. High speed machining is the current tendency to increase the productivity, with the possibility of obtaining good surface quality, possibly eliminating subsequent operations. Due to regulations on the subject of environmental quality, the machining operations have been turned to dry machining or minimal quantity of lubricant (MQL). This work studies the turning process at high speed of gray cast iron GG25 with dry machining and MQL techniques. The operation uses face turning with coated carbide $\left(\mathrm{TiCN} / \mathrm{Al}_{2} \mathrm{O}_{3} / \mathrm{TiN}\right)$ and mixed alumina ceramic $\left(\mathrm{Al}_{2} \mathrm{O}_{3}+\mathrm{TiC}\right)$ with cutting speeds much higher than the traditional recommended values. Comparatively, the wear is significantly smaller in the mixed alumina ceramic tools. The predominant type of wear is the flank wear. The main wear mechanisms are mechanical abrasion and delamination. The increase of feed values shows some reduction on the flank wear. It seems to exist an ideal ratio of oil to air in the MQL system, which makes possible its application for reducing flank wear on the tools. In all conditions tested, the MQL system shows to be able to reduce surface roughness (Ra).

Key Words: gray cast iron; GG25; ceramic; carbide; dry machining; MQL; high speed machining; high speed turning. 


\section{1 - INTRODUÇÃO}

A evolução histórica do homem baseia-se principalmente nos materiais e nos instrumentos utilizados. Observa-se que, neste século, muitos materiais são aperfeiçoados, mas os princípios básicos dos instrumentos de trabalho são utilizados até hoje. Algumas operações tais como, desbastar, cortar e furar, utilizam-se desde o passado. A partir de certo momento, há necessidade de aumentar a produção de tais instrumentos, forçando o homem a criar outros, capazes de repetir mecanicamente os movimentos idealizados por ele para obter as formas desejadas das peças; surgem os protótipos de máquinas-ferramentas. O torno é uma das primeiras e das mais importantes máquinas-ferramentas, pois dele derivam outras máquinas.

A história do homem é a história do domínio da tecnologia dos materiais, portanto, alguns de seus períodos se confundem com os materiais mais usados: Idade da Pedra, Idade do Bronze, Idade do Ferro ou com atividades econômicas relacionadas ao domínio dessa tecnologia, como a Revolução Industrial.

A partir do desenvolvimento da cerâmica, o homem percebe que pode ter um controle maior das formas desejadas, ocorre um grande salto tecnológico, pois pode fazer o mesmo com os metais. Tudo começa com o cobre, depois o bronze e finalmente o ferro. Surgem então alguns processos de fabricação: fundição, forjamento, limagem, afiação, etc. Neste contexto, o metal de maior importância é o ferro, ocorrem vários aperfeiçoamentos de técnicas de produção e no começo a qualidade depende muito do profissional ferreiro.

Atualmente, apesar da grande variedade de materiais metálicos e não-metálicos, utilizase muito o ferro fundido em larga escala, principalmente na industria automobilística (ROTBERG et al., 1997).

O processo de torneamento é muito utilizado na industria, pode-se também utilizar para aplicações em ultraprecisão, pois é mais fácil controlar uma ferramenta com uma aresta de corte do que múltiplas (usinagem por abrasão, por exemplo). O desenvolvimento de materiais para ferramenta possibilita obter medidas com precisão. THOMPSON et al. (1982) desenvolvem um torno com ferramenta de diamante, usina alumínio e obtém rugosidade superficial RMS de 25 a $40 \mathrm{~nm}$ e precisão de $0,25 \mu \mathrm{m}$ (dimensional e de contorno). BYRNE 
et al. (1997) usinam liga AlSi9, com ferramenta MCD (monocrystalline diamond) obtém $\mathrm{R}_{\mathrm{a}}$ mínimo de $0,08 \mu \mathrm{m}$ e com PCD (polycristalline diamond) $\mathrm{R}_{\mathrm{a}}$ mínimo de $0,22 \mu \mathrm{m}$.

“... há 20 anos, todos estavam convencidos de que a retificação iria substituir o fresamento, o torneamento e a furação. Aconteceu exatamente o oposto porque a retificação é uma operação confusa e inflexível. Por outro lado, as máquinas-ferramenta podem manter tolerâncias mais apertadas a velocidades de corte mais elevadas do que no passado e as ferramentas de corte acompanharam essa evolução, tornando-se mais robustas e precisas" (KOELSCH, 2000). O processo de retificação de precisão é o menos dominado e o menos conhecido dos processos de fabricação, e seu desempenho depende extremamente da habilidade e experiência do operador (OLIVEIRA, 1998).

Segundo MACHADO (1988), devido à grande quantidade de materiais para ferramentas no mercado, deve-se conhecer o processo e entender os mecanismos de desgaste das ferramentas para realizar uma ótima escolha, visando economia.

Estudo do fenômeno de contato no qual dominam os mecanismos de desgaste é o grande interesse para "experts" em desenvolvimento de materiais para ferramenta e também para procura de novas aplicações destes materiais devido à necessidade de aumento da produtividade dos processos de usinagem (MEHROTRA, 1998) (KLIMENKO et al., 1992).

$\mathrm{Na}$ industria moderna, tempo é um dos fatores mais importantes dentre os que influenciam o custo de produção, portanto existe uma grande necessidade da diminuição do tempo de produção das peças, diminuindo principalmente tempos de usinagem e número de operações de usinagens, sem acréscimo excessivo ao custo da ferramenta (FERRARESI, 1977). Segundo FERRARESI (1977), às vezes torna-se conveniente diminuir a vida da ferramenta, de modo a reduzir todos os outros fatores que influenciam o custo (custo por hora da máquina, custo por hora da mão-de-obra indireta, etc), conclui-se que o ideal é utilizar as velocidades de corte mais elevadas. Mas deve-se considerar outro fator numa operação econômica, a quantidade de material removido por unidade de tempo, onde um material de ferramenta ideal é aquele que permite remover a mesma quantidade de material em qualquer velocidade. Para TRENT (1991) o custo de usinagem depende muito da taxa de remoção de material e pode-se reduzir com o aumento da velocidade de corte e/ou avanço, mas há limites em relação à vida da ferramenta por causa do calor gerado na aresta de corte.

Atualmente, devido à qualidade das ferramentas de corte, permite-se aplicação de velocidades de corte altíssimas e avanços excepcionais em diferentes processos de usinagem, chamados de HSM (High Speed Machining) e UHSM (Ultra High Speed Machining) (MACHADO, 1988). 
Além disso, como as necessidades do mercado de produtos industriais são diversificadas e o ciclo de vida desses produtos é encurtado, a industria está desenvolvendo o sistema de manufatura ágil, isto é, fabrica somente o produto solicitado e na quantidade necessária, de acordo com a demanda atual (TOMITA, 1999).

A usinagem altamente eficiente é a chave para obtenção de resultados bem-sucedidos do sistema de manufatura ágil para melhorar a flexibilidade até seu limite, sem reduzir a produtividade. Os principais métodos práticos para melhorar a efíciência da usinagem são (TOMITA, 1999):

- aumento da velocidade de corte, o que equivale à usinagem com alta velocidade;

- integração de diversos processos de usinagem em um processo e

- desenvolvimento de um novo método de usinagem pela melhoria radical da usinagem tradicional.

Além disso, a proteção ao meio ambiente assume cada vez maior importância nas técnicas de fabricação. Por exemplo, os fluidos de corte necessários para a usinagem convencional recebem aditivos. Os principais são cloro, enxofre e fósforo. O cloro, por exemplo, libera dioxinas nocivas em temperaturas elevadas (NAKÄGAWA, 2000).

Para atender as normas da série ISO 14000 (Gerenciamento Ambiental), isto é, controle cada vez mais rigoroso da produção sem causar danos ao meio ambiente e garantia da segurança, os atuais custos dos fluidos de corte e seus cuidados (por exemplo, evitar o desenvolvimento bacteriano, armazenamento e eliminação dos fluidos) podem chegar a $15 \%$ dos custos da produção (NAKAGAWA, 2000). Um estudo conduzido pela DaimlerChrysler AG afirma que estes custos podem chegar a $17 \%$, sendo que apenas 2 a $4 \%$ dos custos totais de produção são representados pela ferramenta (NOVASKI \& DÖRR, 1999).

A lubrificação é prejudicial até em termos de refundição dos cavacos, pois estes estão contaminados com fluidos de corte, devendo eliminá-los, adiciona-se custos (NOVASKI \& DÖRR, 1999).

Hoje não existe a possibilidade de eliminação total dos fluidos de corte em todos os processos de usinagem. Estudos recentes chamados de MQL (minimal quantity of lubricant), que é a utilização de mínima quantidade de lubrificação $(<100 \mathrm{ml} / \mathrm{h}$, NOVASKI \& DÖRR, 1999) ou a própria usinagem a seco com o desenvolvimento de materiais para ferramentas, visam a eliminação total ou quase total dos fluidos de corte.

Portanto, atualmente o objetivo é aumentar a produtividade com o aumento da velocidade de corte (HSM) e minimizar o consumo de fluido de corte (MQL) comparado aos métodos convencionais. 


\section{1 - OBJETIVOS}

Neste trabalho o objetivo é a investigação do processo de torneamento com altas velocidades de corte (HSM), aplicado a volantes de motor de combustão interna fabricados com ferro fundido cinzento GG25. Dois tipos de materiais para ferramentas de corte são utilizados, em operação de faceamento com velocidades de corte muito acima dos valores tradicionais. Ensaios são realizados a seco e com a tecnologia MQL (minimal quantity of lubricant), usando-se diferentes valores de vazão de ar e de óleo. O desgaste das ferramentas é medido e analisado em microscópio eletrônico de varredura. A rugosidade superficial também é medida e analisada. 


\section{2 - REVISÃO BIBLIOGRÁFICA}

Os processos de fabricação de materiais metálicos podem ser chamados de processos de conformação dos metais e têm como objetivo a modificação de um corpo para obtenção de uma forma definida. Segundo BRESCIANI FILHO et al. (1986), podem ser divididos em dois grupos: processos mecânicos (as modificações de forma são provocadas pela aplicação de tensões externas) e processos metalúrgicos (as modificações de forma estão relacionadas com altas temperaturas).

Os processos mecânicos são classificados pela geração ou não de cavacos e os processos metalúrgicos pela fusão ou não dos metais.

As peças metálicas obtidas por alguns processos de fabricação primários, tais como fundição, forjamento, etc, geralmente necessitam de determinado acabamento ou não permitem obter certas características, tais como, saliências ou reentrâncias, furos passantes, furos roscados, etc. Os processos de usinagem possibilitam atender estes objetivos, apresentando as melhores condições de custo e produtividade.

\section{$2.1-$ FERRO FUNDIDO}

De todos os materiais à disposição da indústria, certamente o ferro fundido e o aço são os mais utilizados. Estão em aproximadamente $25 \%$ das aplicações em metais na industria, principalmente como fundidos (DeBENEDICTIS, 1997). Além da indústria mecânica, eles estão presentes na construção civil em edifícios, viadutos e pontes, ajudando a manter unidas as estruturas de concreto; na indústria elétrica, na fabricação de motores que auxiliam a movimentar máquinas e equipamentos industriais.

O elemento metálico Ferro é o segundo dos metais mais abundantes da crosta terrestre $(A l=7,5 \%$ e $F e=4,7 \%$, embora não ocorra puro na natureza, exceto nos meteoritos. Encontra-se na natureza na forma de minérios de ferro (hematita - mais comum, magnetita, braunita, limonita, siderita, pirita e calcopirita).

Ferro fundido é uma liga ternária (ferro-carbono-silício), com teores de carbono geralmente acima de $2,0 \%$, em quantidade superior à que pode ser retida em solução sólida 
na austenita, de modo a resultar carbono parcialmente livre, na forma de veios ou lamelas da grafita (CHIAVERINI, 1984), contendo teor de silício entre 1 a 3\% (ASM, 1978). Pode-se obter amplas variações nas propriedades pela variação de teor do carbono e silício, pela adição de vários elementos metálicos e não-metálicos, e pela forma de fundição e tratamento térmico. Na presença de fósforo com teor $>0,20 \%$ forma-se steadita, um constituinte duro, que reduz a vida da ferramenta na usinagem (ASM, 1989b).

As propriedades mecânicas (resistência, ductilidade e módulo de elasticidade) dependem fortemente da estrutura e da distribuição dos constituintes microestruturais, e as propriedades fisicas (condutividade térmica e capacidade de amortecimento) também são fortemente influenciadas pela microestrutura. Em qualquer ferro fundido, a característica microestrutural de efeito mais significante nessas propriedades é a grafita pura (ASM, 1978).

Os ferros fundidos constituem um grupo de ligas de importância fundamental para a industria, pois mediante introdução de elementos de liga, aplicação de tratamentos térmicos adequados e pelo desenvolvimento do ferro fundido nodular, é viável seu emprego em aplicações antes exclusivas dos aços (CHIAVERINI, 1984). Segundo DeBENEDICTIS (1997), nos recentes anos aumenta-se a rigidez e ductilidade com adição de silício, cromo, molibdênio e cobre, resultando em classes de ferro fundido com dureza de 150 a $300 \mathrm{HB}$.

Existem classificações dos ferros fundidos segundo grupos mais detalhados (BRESCIANI FILHO, 1988), mas a maioria das classificações baseia-se em cinco tipos de ligas, conforme a forma como o carbono se apresenta na massa metálica solidificada, após o processo de fundição para a fabricação de peças (cementita $\mathrm{Fe}_{3} \mathrm{C}$ ou carbono na condição de grafita de diferentes morfologias - veios ou nódulos): ferro fundido branco; ferro fundido mesclado; ferro fundido maleável; ferro fundido nodular e ferro fundido cinzento. No ANEXO A, estão as principais características desses ferros fundidos.

Segundo BOEHS et al. (2000), a clássica fundição em moldes de areia, é uma técnica de fundição que geralmente proporciona defeitos na microestrutura e conseqüentemente redução nas propriedades mecânicas dos fundidos. Existe uma técnica alternativa denominada fundição contínua, que vaza continuamente o ferro no estado líquido, em uma matriz de grafita, envolvida por uma camisa de água que tem a função de promover o resfriamento contínuo dessa matriz.

Esta técnica pode produzir ferro fundido cinzento, nodular e bainítico. Apresenta as seguintes vantagens (BOEHS et al., 2000): redução de porosidade; diminuição da quantidade de rechupes; microestrutura mais fina e necessidade de menos sobremetal para remoção da superfície bruta de fundição das peças que são usinadas. 


\subsection{1 - Principais características dos ferros fundidos cinzentos}

Usualmente contém 2 a $4 \%$ de C e 1 a $3 \%$ de Si (ASM, 1978). Apresenta a grafita precipitada na forma de flocos ou veios, que confere uma aparência acinzentada na fratura de um corpo de prova. As condições de fundição podem alterar a forma da grafita precipitada, e a morfologia da grafita tem notável influência nas propriedades mecânicas do material. A matriz pode ser de natureza predominantemente ferrítica ou perlítica, que depende da velocidade de resfriamento, do teor de silício e do teor de carbono equivalente (carbono equivalente $=$ teor de carbono $+1 / 3$ teor de silício e fósforo) (BRESCIANI FILHO, 1988). Resfriamento mais rápido pode produzir mottled iron, onde o carbono está presente na forma de cementita e grafita; já resfriamento muito lento de ferro fundido contendo grandes porcentagens de silício e carbono, normalmente produz tanto cementita como perlita com flocos grosseiros de grafita (ASM, 1978). O cromo e o cobre são formadores de perlita, enquanto molibdênio tende diminuir o espaçamento lamelar (HEATH, 1989). A adição de elementos de liga pode permitir a obtenção de estrutura martensítica após tratamento térmico (BRESCIANI FILHO, 1988).

Segundo EZUGWU et al. (1995), é capaz de ter perlita com resistência variável dependendo do seu espaçamento intergranular. Resfriamento lento (aproximadamente $3^{\circ} \mathrm{C} / \mathrm{min}$ ) do começo ao fim da transformação resulta em espaçamento grosseiro da perlita $\mathrm{e}$ uma dureza de aproximadamente $210 \mathrm{HB}$, enquanto resfriamento rápido resulta em uma estrutura muito mais fina e aumenta a dureza para $450 \mathrm{HB}$.

Segundo HEATH (1989), a velocidade de resfriamento depende da seção transversal da peça e das técnicas de fundição. Numa regra geral, fundido com resfriamento rápido e com pequenas seções transversais tem menor tendência para formação de ferrita livre. Porém, com resfriamento muito rápido, podem ocorrer resfriamento localizado e formar ferro fundido branco e carbonetos intercelulares (HEATH, 1989).

Apresenta como elementos fundamentais de liga o carbono e o silício, onde na estrutura uma parcela relativamente grande do carbono está no estado livre (grafita) e outra parcela no estado combinado cementita $\left(\mathrm{Fe}_{3} \mathrm{C}\right)$.

Segundo BRESCIANI FILHO (1988) e CHIAVERINI (1984), suas propriedades dependem muito dos veios de grafita presentes, sendo as seguintes: boa resistência mecânica (resistência à tração/compressão e dureza); resistência ao desgaste (devido à elevada dureza); tem boa usinabilidade (provocada pelo efeito de quebra do cavaco) e da lubrificação da grafita; fácil fusão e moldagem; metal anti-frição e capacidade para amortecimento de vibrações. 
A dureza do ferro fundido cinzento é um valor intermediário entre a dureza da grafita e a dureza da matriz metálica dura. Portanto variação no tamanho e distribuição da grafita causa variações na dureza (ASM, 1978).

Os ferros fundidos cinzentos são empregados nas indústrias automobilística, de equipamentos agrícolas, de máquinas, na mecânica pesada, na fabricação de blocos e cabeçotes de motor, carcaças, platôs de embreagem, suportes, barras e barramentos para máquinas industriais.

\section{2 - MATERIAIS PARA FERRAMENTAS}

Com a introdução de novos materiais e novas tecnologias de fabricação ocorre neste século um grande desenvolvimento das ferramentas de corte.

$\mathrm{Na}$ década de 80 , análises e comparações das condições de corte que as industrias adotam, mostram condições inferiores das recomendadas, por causa da ausência de equipamentos que apresentem altas velocidades de corte, sistema de manufatura rígida, potência e precisão, que assegurem possibilidades ótimas para usar ferramentas de materiais cerâmicos e ultraduros (GARIBOV \& RYNSKOV, 1990). Para MACHADO (1988), nos anos 80 há um grande crescimento do número de ferramentas disponíveis no mercado, não por causa da grande quantidade de materiais similares, mas por causa do avanço tecnológico visando o aumento da produtividade.

Segundo KOELSCH (2000) e DINIZ et al. (1999), para os materiais para ferramentas quatro propriedades são importantes, cada uma com maior ou menor importância: dureza a quente, resistência ao desgaste (desgaste por abrasão, propriedade muito ligada à dureza a quente do material), tenacidade (resistência aos choques inerentes do processo) e estabilidade química (evitar o desgaste por difusão, bastante importante em altas velocidades de corte). EZUGWU et al. (1995) complementam a necessidade de resistência suficiente para evitar falha por fratura. Segundo ANGUS (1976), não existe uma relação clara entre dureza e resistência ao desgaste.

A busca de ferramentas com maior dureza e maior resistência ao desgaste está ligada à necessidade de velocidades de corte cada vez mais altas para atender o aumento da produtividade, mas com isso a tenacidade do material da ferramenta diminui.

Nenhuma classe de material para ferramenta apresenta todos estas características, conseqüentemente, a escolha do material depende de vários fatores (DINIZ et al., 1999) (EZUGWU et al., 1995). 
Há muito tempo tem sido aceito como regra geral na industria de metal duro que algo em torno de $80 \%$ de todos os insertos são de alguma forma mal aplicados (KATBI, 1996).

Segundo DINIZ et al. (1999), para seleção criteriosa do material da ferramenta, deve-se ponderar uma série de fatores, que influenciam nas propriedades requisitadas anteriormente:

- material a ser usinado (dureza e tipo de cavaco formado);

- processo de usinagem;

- condições da máquina-ferramenta (potência, rotações, estado de conservação, etc);

- forma e dimensões da ferramenta (formas não padronizadas, muitas vezes são feitas de aço rápido ou de metal duro que possa ser soldado ao suporte);

- custo do material da ferramenta (relação custo-benefício);

- condições de usinagem (operações de acabamento em peças já usinadas anteriormente e que não apresentam excentricidade, camada endurecida, etc, exigem ferramentas mais resistentes ao desgaste e não precisam de muita tenacidade; em operações de desbaste em peças que apresentam camada endurecida, excentricidade, etc, a ferramenta deve apresentar maior tenacidade, em detrimento da resistência ao desgaste, sendo fundamental a dureza a quente, resistência ao choque térmico e tenacidade);

- condições da operação (se o corte é interrompido e/ou o sistema máquina-ferramentadispositivo de fixação-peça for pouco rígido, exige-se uma ferramenta mais tenaz).

Segundo EZUGWU et al. (1995), o melhor material para dada operação não é necessariamente aquele que proporciona maior vida da ferramenta ou é de menor custo. Confiabilidade e previsibilidade do desempenho são também importantes na escolha das ferramentas de corte, particularmente com o aumento da automação industrial. A habilidade de predizer, com precisão e eficientemente, o desempenho da ferramenta durante a operação de usinagem melhora a usinagem dos componentes, reduz-se, assim, significativamente, o custo de usinagem (o qual às vezes pode ser tão alto quanto $70 \%$ do custo total de fabricação).

Para alguns, desempenho, significa "peças por aresta de corte" ou "centavos por peça", enquanto para outros pode significar bons acabamentos, excelente tenacidade ou algumas outras centenas de características. Desempenho no ambiente competitivo atual é a soma de iguais partes de confiabilidade, previsibilidade e produtividade (Figura 1) (KATBI, 1996). 


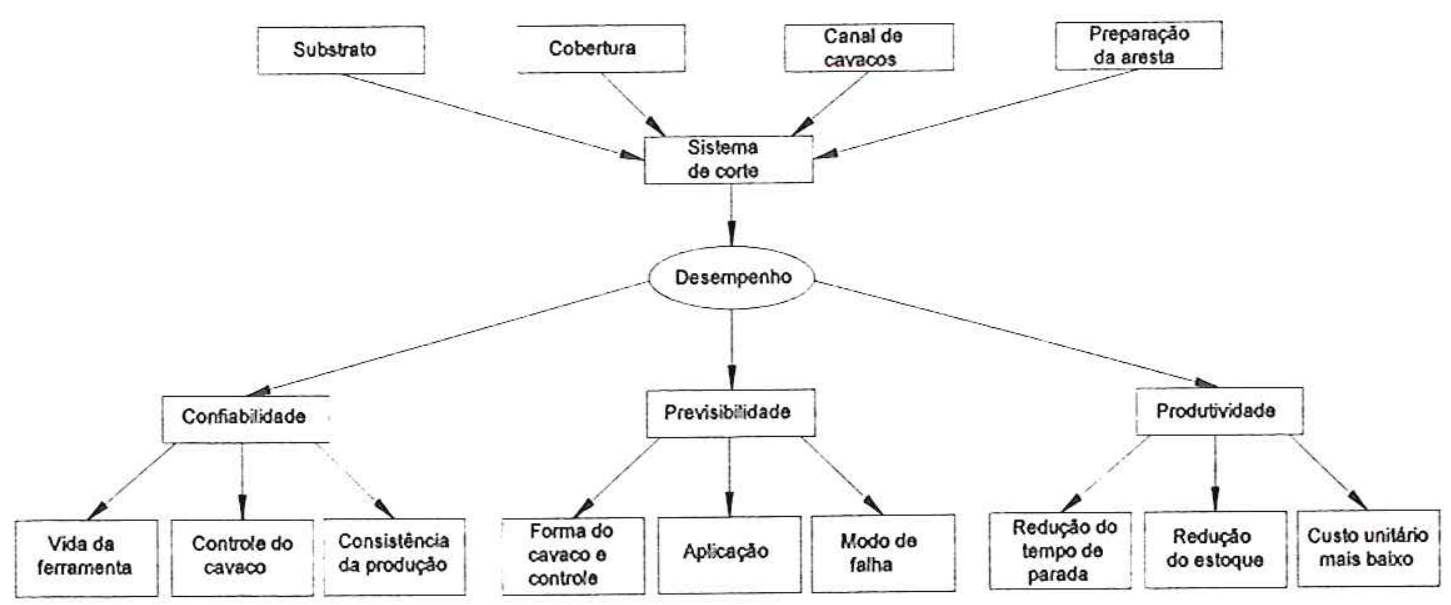

Figura 1 - Seleção adequada de ferramenta de corte (KATBI, 1996)

Para a seleção correta de uma ferramenta para uma aplicação particular é necessário começar com as expectativas corretas. Por exemplo, nos EUA práticas tradicionais enfatizam várias medições relacionadas à velocidade: quantas peças por aresta ou por hora podem ser produzidas. Entretanto no Japão, verifica-se a valorização da confiabilidade e previsibilidade, reflexo do grau de dependência quanto a processos de produção sem supervisão humana (KATBI, 1996).

Uma vez definido o desempenho ótimo, pode-se iniciar o processo de seleção da ferramenta, considerando cinco fatores principais (KATBI, 1996):

a) SUBSTRATO: principal componente estrutural da ferramenta. A tecnologia atual torna possível variar seletivamente a quantidade de ligante em diferentes áreas do substrato para obter uma combinação de propriedades. O controle do tamanho de grão também é importante (KATBI, 1996).

b) COBERTURA: fornece resistência ao desgaste, lubricidade, isolamento térmico e resistência ao ataque químico pelo material usinado em temperaturas elevadas (KATBI, 1996).

Segundo SCHULZ et al. (2000), as coberturas usadas em ferramentas de corte, de acordo com suas propriedades, podem ser classificadas em:

- endurecedoras: coberturas com alta dureza (freqüentemente acima de $2500 \mathrm{HV}$ ), proporcionam reduzido desgaste por abrasão e pequena adesão do material usinado (SCHULZ et al., 2000) e

- lubrificantes: possuem como base uma cobertura de material duro, sobre o qual é depositada uma cobertura de material macio (por exemplo, dissulfeto de molibdênio $\mathrm{MoS}_{2}$ ) ou uma segunda cobertura de material duro com propriedades lubrificantes 
(por exemplo, carbono contendo metal - WC/C). O objetivo é redução do atrito, para possibilitar usinagem a seco e usinagem com mínima quantidade de lubrificante (MQL) (SCHULZ et al., 2000) (HUSTON et al., 1998).

Os materiais de cobertura mais comuns são o carboneto de titânio (TiC), nitreto de titânio (TiN), carbonitreto de titânio (TiCN) e o óxido de alumínio $\left(\mathrm{Al}_{2} \mathrm{O}_{3}\right)(\mathrm{KATBI}$, 1996) (PEYRE \& VINTERHOLLER, 1994). Coberturas cerâmicas à base de óxido de alumínio $\left(\mathrm{Al}_{2} \mathrm{O}_{3}\right)$, diamante policristalino (PCD) e nitreto cúbico de boro ( $\mathrm{CBN}$ ), geralmente são usadas apenas em combinação com outros tipos de coberturas (SCHULZ et al., 2000). Segundo TAKATSU (1990), de um modo geral a resistência ao desgaste térmico obedece à seguinte classificação: $\mathrm{Al}_{2} \mathrm{O}_{3}>\mathrm{TiN}>\mathrm{TiCN}>\mathrm{TiC}$, porém no desgaste abrasivo esta ordem inverte.

A aplicação destas coberturas pode ser realizada por dois métodos principais: deposição química a vapor (CVD, coberturas de 10 a $15 \mu \mathrm{m}$ ) e deposição física a vapor (PVD, coberturas de 2 a $5 \mu \mathrm{m}$ e temperaturas de aplicação muito mais baixa que CVD) (KATBI, 1996). Segundo TEETER (1994), o processo PVD é executado de maneira mais limpa, sem subprodutos de reação a temperatura abaixo de $510^{\circ} \mathrm{C}$. No APÊNDICE I, encontram-se as vantagens e desvantagens desses processos. Para juntar as vantagens dos dois processos, pode-se combinar, por exemplo, aplicação de TiCN por CVD e depois TiN por PVD (PEYRE \& VINTERHOLLER, 1994). Novos materiais para cobertura, tais como, TiAlN e $\mathrm{TiB}_{2}$ estão sendo aplicados pelo processo PVD (HUSTON et al., 1998).

No caso de torneamento (corte contínuo), a cobertura constitui uma barreira térmica e deve apresentar boas propriedades de atrito e resistência à oxidação (PEYRE \& VINTERHOLLER, 1994).

c) QUEBRA-CAVACOS: modificação da forma do cavaco, influência nas forças de corte e na vida útil da ferramenta. Segundo KATBI (1996), o projeto do quebra-cavacos é o principal determinante da capacidade de avanço e profundidade de usinagem.

d) PREPARAÇÃO DA ARESTA DE CORTE: quanto mais polida, mais forte é a aresta de corte (KATBI, 1996).

e) FORMA: existem diversas geometrias de ferramentas, portanto, com diferentes ângulos das arestas de corte.

Para MACHADO (1988), as ferramentas de corte passam por três grandes impactos em sua história: a introdução do aço rápido, do metal duro e da cerâmica. 
Segundo DINIZ et al. (1999) e FERRARESI (1977), não existe uma classificação geral de materiais para ferramentas. Entretanto, com base nos seus característicos químicos, eles podem ser agrupados da seguinte maneira (ordem crescente de dureza a quente e resistência ao desgaste por abrasão): aço rápido, aço rápido com cobertura, Coronite ${ }^{\mathrm{TM}}$, metal duro, metal duro com cobertura, material cerâmico, nitreto cúbico de boro policristalino (PCBN) e diamante (MCD e PCD).

O diamante e o PCBN são os dois materiais mais duros conhecidos e comumente são chamados de materiais ultraduros (VASILASH, 1996) (HEATH, 1989) (MACHADO, 1988), sendo principalmente usados na usinagem de acabamento e semi-acabamento (ZLENKO et al., 1990).

Ferramentas de materiais sintéticos ultraduros (diamante sintético e nitreto cúbico de boro) e cerâmicas são usadas por mais de 25 anos na manufatura de peças automotivas, onde permite um aumento significativo da produtividade, da qualidade, das condições de usinagem e do tempo de vida da ferramenta em operações de acabamento e semi-acabamento de peças metálicas. Dados das principais industrias soviéticas do ramo automobilístico mostram que estes tipos de ferramenta são usados com sucesso nas seguintes operações: torneamento externo de pistões, volantes, rolamentos de esferas, cubos de rodas; face superior de pistões, engrenagens, excêntricos, faces e largura de canais em pistões; furações em pistões, caixas, bielas, luvas cilíndricas, cavidade de cilindros e cabeçotes, tambores de freio, capas de rolamentos; fresamento de face de cabeçotes, usinagens gerais de cabeçotes, caixas de rolamentos (GARIBOV \& RYNSKOV, 1990).

Segundo ROTBERG et al. (1997), em torneamento de alta velocidade de ferro fundido os materiais típicos para ferramentas são: metal duro revestido com multicamadas de cerâmica, cerâmica à base de alumina $\left(\mathrm{Al}_{2} \mathrm{O}_{3}\right)$, cerâmica à base de nitreto de silício $\left(\mathrm{Si}_{3} \mathrm{~N}_{4}\right) \mathrm{e}$ nitreto cúbico de boro policristalino (PCBN).

O diamante é carbono puro, portanto, inadequado para usinagens de materiais que reajam com o carbono, tais como o ferro, superligas de níquel ou cobalto, etc. Ocorre difusão do material da ferramenta para peça e desgasta-se rapidamente a ferramenta quando a temperatura da aresta de corte atinge cerca de $600^{\circ} \mathrm{C}$. Segundo HEATH (1989), o diamante é recomendado para usinagem de materiais não-ferrosos, tais como, ligas de alumínio, ligas de cobre, plásticos abrasivos, compostos de vidro e fibra de carbono, cerâmicas a verde, metal duro, madeiras, plásticos, pedras naturais e concretos. 


\subsection{1 - Aço Rápido}

Em 1905, Taylor e White desenvolvem o primeiro aço rápido $(0,67 \% \mathrm{C}, 18,91 \% \mathrm{~W}$, $5,47 \% \mathrm{Cr}, 0,11 \% \mathrm{Mn}, 0,29 \mathrm{~V}$ e apropriado tratamento térmico) (TRENT, 1991) (MACHADO, 1988).

$\mathrm{Na}$ época é o material de ferramenta que suporta as maiores velocidades de corte. É um material tenaz, de elevada resistência ao desgaste, elevada dureza a quente (comparado com aço carbono usado para ferramentas) e alta dureza em temperatura ambiente, pode-se utilizálo até temperaturas de corte de $600^{\circ}$. Sua dureza a quente é proporcional à quantidade de elementos de liga dissolvidos durante o tratamento térmico e que depois permanecem dissolvidos. A resistência à abrasão depende do tipo e número de carbonetos duros que se formam. A tenacidade depende dos elementos de liga e do grau de dissolubilidade destes. Geralmente quando tem resistência à abrasão, tem pouca tenacidade (DINIZ et al., 1999). Nos aços rápidos normalmente não ocorre desgaste por difusão, por não serem utilizados em altas velocidades de corte.

As normas AISI e SAE classificam o aço rápido em duas categorias: categoria "T" (base de tungstênio W ou W-Co) e categoria "M" (base de molibdênio Mo ou Mo-Co).

Os elementos de liga mais comuns nos aços rápidos são: carbono (aumenta a dureza e possibilita a formação de carbonetos), tungstênio (forma carbonetos que elevam resistência ao desgaste e dureza a quente), molibdênio (mesmo efeito do tungstênio), vanádio (forma o carboneto mais duro nos aços rápidos, e aços com alto teor de carbono e vanádio tem a melhor resistência ao desgaste), nióbio (característica semelhante ao vanádio e é mais barato no Brasil), cromo (junto com o carbono é o principal responsável pela alta temperabilidade) e cobalto (aumenta a dureza a quente) (DINIZ et al., 1999) (FERRARESI, 1977).

As aplicações dos aços rápidos são principalmente em fresas, cossinetes, brochas, matrizes a até ferramentas de barras para aplicações em torneamento de peças de diâmetros reduzidos (MACHADO, 1988).

Devido às características do cobalto, aços rápidos ao cobalto são mais recomendados para cortes em desbaste pesado e para a usinagem de materiais que apresentam cavacos curtos como o ferro fundido, onde a temperatura se eleva bastante devido à impossibilidade de utilização de fluido de corte. 


\subsection{2 - Aço Rápido com Cobertura}

Pode-se aumentar o desempenho e a economia de uma ferramenta de corte através da aplicação de uma fina cobertura resistente ao desgaste sobre a superfície da ferramenta (LIM et al., 1995).

Segundo DINIZ et al. (1999), para diversas ferramentas de usinagem tais como brocas, machos, alargadores, brochas, cortadores de dentes de engrenagens e alguns tipos de fresas, onde a aplicação de materiais mais resistentes que o aço rápido é muito restrito, como o metal duro e a cerâmica, devido à forma, dimensão e as condições de emprego, desenvolvem-se melhorias no aço rápido, principalmente através da aplicação de uma camada de cobertura de um material mais resistente ao desgaste como o nitreto de titânio e o carbonitreto de titânio, através do processo PVD (deposição física a vapor) a uma temperatura na faixa de 450 a $500^{\circ} \mathrm{C}$.

Outras camadas utilizadas são: TiC, $\mathrm{HfN}$ e $\mathrm{Al}_{2} \mathrm{O}_{3}$ (LIM et al., 1995) (TRENT, 1991) (MACHADO, 1988). PEYRE \& VINTERHOLLER (1994) acrescentam as camadas de CrC e CrN. A cobertura mais utilizada é TiN (DINIZ et al., 1999) (LIM et al., 1995) (TRENT, 1991).

O processo CVD (deposição química a vapor) exige que as ferramentas sejam aquecidas a temperaturas elevadas (próximas de $1000^{\circ} \mathrm{C}$ ), e provoca alterações metalúrgicas nos aços rápidos, tais como revenimento. O mesmo não acontece com o processo PVD (DINIZ et al., 1999) (TEETER, 1994) (TRENT, 1991) (MACHADO, 1988).

\subsection{3 - Coronite ${ }^{\mathrm{TM}}$}

Material para ferramenta recente (desenvolvido pela Sandvik Coromant), utiliza-se principalmente em fresas de topo, que são ferramentas de pequeno diâmetro que, quando fabricadas de aço rápido não propiciam a eficiência que se deseja e de metal duro podem não atingir as altas velocidades de corte necessárias para a eficiência desse material. Composto de finas partículas de nitreto de titânio $(0,1 \mu \mathrm{m}$ de diâmetro e 35 a $60 \%$ do volume do material) numa matriz de aço temperado (DINIZ et al., 1999). 


\subsection{4 - Metal Duro}

O metal duro é um produto da metalurgia do pó feito de partículas duras ( 1 a $10 \mu \mathrm{m})$ de carbonetos de metais refratários (carbonetos de tungstênio, titânio, tântalo e nióbio), sinterizados com um ou mais metais do grupo do ferro (ferro, níquel ou cobalto), forma-se um corpo de alta dureza e resistência à compressão. Os carbonetos ocupam de 60 a 95\% do volume do material e o metal aglomerante normalmente é o cobalto. Quanto menor o tamanho das partículas duras, melhores as propriedades mecânicas (GERDES, et al., 1996). O metal duro é melhor que o aço rápido em termos de resistência a abrasão extrema (ASM, 1978).

A grande aplicação destes materiais deve-se ao fato de possuir a combinação de resistência ao desgaste, resistência mecânica e tenacidade em altos níveis (MARCONDES, 1990) (MACHADO, 1988) (FERRARESI, 1977).

Cerca de metade do potencial mundial entre os materiais de ferramentas de corte, medido em valor monetário, tende para o metal duro. Do restante, cerca de $40 \%$ favorecem o aço rápido e $10 \%$ os materiais avançados. Situação inversa que 10 anos atrás, quando o metal duro ocupa a posição do aço rápido (KOELSCH, 2000).

Com a evolução das classes de metal duro, melhora-se a resistência ao desgaste, a tenacidade e a dureza a quente (alta dureza e estabilidade química em alta temperatura), o qual possibilita a ascensão do metal duro, devido a quatro avanços tecnológicos: diminuições do tamanho de grão, melhores ligantes, gradientes de concentração de cobalto e novas coberturas (KOELSCH, 2000).

As principais características do metal duro são:

- O metal duro pode usinar qualquer tipo de metal, desde que sua dureza não ultrapasse 45 HRc (DINIZ et al., 1999);

- Algumas características podem ser controladas, tais como, pode-se ter metal duro de elevada tenacidade, como também metal duro com alta resistência ao desgaste ou dureza a quente (DINIZ et al., 1999);

- Trabalha com eficiência em altas velocidades de corte e resiste mais as altas temperaturas de corte que qualquer aço rápido (DINIZ et al., 1999);

- A porosidade e a microestrutura também podem ser controladas, afetando-se a capacidade de corte (DINIZ et al., 1999) (FERRARESI, 1977);

- À medida que a quantidade de cobalto diminui e aumenta a porcentagem de carbonetos, a dureza a quente aumenta e a tenacidade (resistência à ruptura transversal) diminui (DINIZ et al., 1999); 
- Geralmente quanto mais cobalto, a ferramenta possui maior resistência à quebra e maior resistência ao impacto. Em contrapartida, a ferramenta torna-se mais macia e não opera em elevadas temperaturas de corte. E quanto mais duro o carboneto, a ferramenta suporta mais calor e elevadas velocidades de corte (KOELSCH, 2000);

- Existem gradientes de concentração de cobalto nas ferramentas, isto é, concentrações diferenciadas de cobalto na superficie e no núcleo (KOELSCH, 2000);

- Atualmente usa-se níquel como ligante para usinar em temperaturas mais elevadas (KOELSCH, 2000);

- O coeficiente de dilatação térmica é cerca de metade do aço em temperaturas desde a ambiente até $675^{\circ} \mathrm{C}$. Quando o porta ferramentas for de aço e a fixação por meio de solda deve-se tomar precauções na solda, para possibilitar espaço da dilatação diferenciada do metal duro e do porta ferramentas (DINIZ et al., 1999) (MARCONDES, 1990) (FERRARESI, 1977);

- Metal duro com alto teor de cobalto tem melhores propriedades para solda que metal duro com baixo teor (MARCONDES, 1990);

- Com relação ao tamanho de grão das partículas duras:

- partículas grandes produzem maior tenacidade, enquanto partículas pequenas auxiliam na obtenção de um metal duro mais duro e resistente (DINIZ et al., 1999);

- grãos submícron conferem maior densidade e tenacidade à fratura (KOELSCH, 2000);

- um tamanho de grão mais uniforme e pequeno melhora a resistência à compressão e a resistência à deformação (KOELSCH, 2000);

- grãos mais finos criam aresta de corte mais fina (KOELSCH, 2000);

- carboneto de cromo $\left(\mathrm{Cr}_{3} \mathrm{C}_{2}\right)$ e carboneto de vanádio (VC) inibe o crescimento dos grãos (KOELSCH, 2000).

Segundo a norma ISO R513 (SANTHANAM \& TIERNEY, 1989), os tipos de metal duro são classificados em três grupos:

- P (sub-grupos P01 a P50):

- constituído de metais duros de elevado teor de TiC-TaC (DINIZ et al., 1999) e às vezes $\mathrm{NbC}$ (MACHADO, 1988);

- elevada dureza a quente e resistência ao desgaste (mais resistente em relação ao desgaste de cratera que as classes $\mathrm{M} \mathrm{e} \mathrm{K}$ - principalmente difusão, pois o complexo de ferro e titânio é muito mais resistente que o de ferro-tungstênio) (DINIZ et al., 
1999). Adição de TiC e TaC elimina a tendência para formação de aresta postiça de corte e, freqüentemente melhora a resistência à oxidação (KOELSCH, 2000);

- recomendação: aços e materiais dúcteis em geral (materiais que produzem cavacos contínuos) (KOELSCH, 2000) (DINIZ et al., 1999) (MARCONDES, 1990) (MACHADO, 1988) (FERRARESI, 1977).

- M (sub-grupos M10 a M40):

- propriedades intermediárias entre os grupos P e K (DINIZ et al., 1999) (MACHADO, 1988);

- recomendação: ferramentas de múltiplas aplicações (DINIZ et al., 1999).

- K (sub-grupos K01 a K40):

- primeiro tipo de metal duro (KOELSCH, 2000) (DINIZ et al., 1999);

- composto por carbonetos de tungstênio aglomerados pelo cobalto (WC + Co puros) (DINIZ et al., 1999) (MACHADO, 1988);

- possui melhor dureza e tenacidade que a classe P (KOELSCH, 2000);

- desvantagem: não resiste ao desgaste de cratera (KOELSCH, 2000) (DINIZ et al, 1999);

- recomendação: ferros fundidos e latões (materiais frágeis que formam cavacos curtos) (DINIZ et al., 1999) (MARCONDES, 1990) (MACHADO, 1988) (FERRARESI, 1977). É instável com o aço, pois o carbono da ferramenta flui para os cavacos austeníticos e cria uma cratera ao longo da aresta de corte (KOELSCH, 2000).

Para melhorar as propriedades mecânicas do metal duro é necessário diminuir os grãos, mas na sinterização convencional ocorrem altas pressões onde ocorre excessivo crescimento de grão. Portanto desenvolve-se uma nova tecnologia de sinterização sem pressão e com moderadas temperaturas chamada Microwave Sintering. Metal duro com conteúdo muito baixo de metal aglomerante espera-se ter uma excelente resistência à corrosão e elevada dureza (GERDES et al., 1996).

\subsection{5 - Metal Duro com Cobertura}

$\mathrm{O}$ inserto de metal duro com cobertura surge antes do aço rápido com cobertura (MACHADO, 1988). As coberturas de carboneto de titânio (TiC) são introduzidas comercialmente em 1969 (GRAHAM, 1994). 
Os insertos de metal duro com cobertura possuem de uma a três camadas que aumentam a resistência ao desgaste das superficies que entram em contato com o cavaco e a peça, e o núcleo permanece com a tenacidade característica do metal duro mais simples (WC $+\mathrm{Co}$ ) (DINIZ et al., 1999) (MACHADO, 1988). Com isso pode-se conciliar em um mesmo material, a tenacidade, a resistência ao desgaste e a dureza a quente (DINIZ et al., 1999) (PEYRE \& VINTERHOLLER, 1994) (ZHOU et al., 1988), que segundo GRAHAM (1994), torna o uso deste material bem flexível. Tudo isso é possível através dos processos de CVD e PVD (ENDLER et al., 1994) (PEYRE \& VINTERHOLLER, 1994). Normalmente a cobertura é de carboneto de titânio, óxido de alumínio, nitreto de titânio, carbonitreto de titânio, carboneto de háfnio e nitreto de háfnio, sendo os três primeiros mais usados (DINIZ et al., 1999) (ENDLER et al., 1994) (GRAHAM, 1994) (MACHADO, 1988) (ZHOU et al., 1988).

Existe uma linha de pesquisa para descobrir meios de aumentar o conteúdo de alumínio em coberturas de nitreto de titânio alumínio (TiAIN) pelo processo PVD, pois se acredita que o aluminio na cobertura forma uma camada de óxido de alumínio muito fina e transitória conforme penetra no corte e fica quente (KOELSCH, 2000).

Segundo DINIZ et al. (1999), geralmente as camadas de cobertura são aplicadas utilizando-se o processo CVD e depositadas conforme abaixo:

- a primeira camada é o carboneto de titânio ou carbonitreto de titânio, pode-se às vezes ser a única camada de cobertura;

- insertos com duas camadas de cobertura: a segunda camada é de óxido de alumínio ou nitreto de titânio;

- insertos com três camadas de cobertura: uma camada de TiN recobre uma camada intermediária de $\mathrm{Al}_{2} \mathrm{O}_{3}$, sendo a primeira camada de TiC.

As principais características destas camadas são:

- carboneto de titânio (TiC): excelente resistência ao desgaste por abrasão, afinidade fisico-química com o metal duro, dureza de $3000 \mathrm{HV}$, baixa tendência de soldagem com o material da peça (dificulta desgaste por adesão e formação de aresta postiça de corte), baixo coeficiente de dilatação térmica (DINIZ et al., 1999). Segundo GRAHAM (1994), devido à sua dureza em temperaturas baixas e intermediárias, é mais eficaz em velocidades médias, onde a abrasão mecânica é o principal mecanismo de quebra. Espessura de camada de 4 a $8 \mu \mathrm{m}$ (DINIZ et al., 1999); 
- carbonitreto de titânio ( $\mathrm{TiCN}$ ): possui propriedades similares ao TiC, porém tem coeficiente de atrito mais baixo (DINIZ et al., 1999). Possui melhor dureza que TiN (JINDAL et al., 1999);

- óxido de alumínio $\left(\mathrm{Al}_{2} \mathrm{O}_{3}\right)$ : estabilidade térmica em temperaturas elevadas (material cerâmico refratário), alta resistência ao desgaste por abrasão, dificulta o desgaste por difusão, alta resistência a ataques químicos e à oxidação, principal responsável pela baixa tendência de formação de desgaste de cratera (DINIZ et al., 1999) (GRAHAM, 1994). Sua resistência ao desgaste de cratera é mais que o dobro do TiC e TiN, e é diretamente proporcional à espessura da cobertura (GRAHAM, 1994). Possui comportamento oposto da camada de TiN, TiCN e outras mais comuns, ao invés de tornar mais condutor térmico à medida que fica quente, torna-se menos condutor e atua como uma barreira térmica (KOELSCH, 2000). Segundo GRAHAM (1994), devido a essas características é a cobertura que oferece o maior potencial para a melhora da produtividade. Desvantagens: pequena resistência a choques térmicos e mecânicos (DINIZ et al., 1999);

- nitreto de titânio (TiN): reduz o coeficiente de atrito entre a ferramenta e o cavaco (DINIZ et al., 1999) (TEETER, 1994), quimicamente mais estável que o TiC (menor tendência à difusão com aços) (DINIZ et al., 1999) e possui maior resistência ao desgaste de cratera que o TiC (PEYRE \& VINTERHOLLER, 1994). Preferido em baixas velocidades, por ser mais eficaz na prevenção de formação de aresta postiça de corte (GRAHAM, 1994). Espessura de camada de 5 a $7 \mu \mathrm{m}$ (DINIZ et al., 1999).

A espessura total das camadas varia entre 2 a $12 \mu \mathrm{m}$. Quando aumenta a espessura da cobertura, a resistência ao desgaste aumenta, porém diminui a tenacidade e aumenta a tendência ao lascamento das arestas.

Segundo RICHTER et al. (1996), normalmente as coberturas afetam não somente a dureza superficial, mas também a tenacidade. Através do processo CVD, diminui a resistência do metal base pela introdução de tensões de tração na superficie (RICHTER et al., 1996) (PEYRE \& VINTERHOLLER, 1994), enquanto que pelo processo PVD resulta em tensões de compressão (JINDAL et al., 1999) (RICHTER et al., 1996) (PEYRE \& VINTERHOLLER, 1994). Segundo JINDAL et al. (1999), este efeito de tensões residuais de compressão do processo PVD aumenta a vida da ferramenta, retarda o desgaste abrasivo e de entalhe, sendo que este efeito é menos importante no torneamento contínuo que em operações de fresamento. 
Atualmente segundo KOELSCH (2000), existe uma linha de pesquisa para depositar camadas mais espessas de óxido de alumínio a partir da deposição química de vapor de temperatura média (MTCVD), a qual deposita o isolador duro a temperaturas muito mais baixas e com menos distorção do substrato que os processos convencionais CVD.

As principais áreas de aplicação são operações de acabamento e semi-acabamento de aços e ferros fundidos (torneamento e fresamento), devido à alta resistência ao desgaste (ZHOU et al., 1988); e usinagem com alta velocidade de corte de aços-liga, ferros fundidos, superligas e aços inoxidáveis (MACHADO, 1988).

\subsection{6 - Cermet}

Cermet é uma classe de materiais para ferramenta que cresce em termos de importância e do seu lugar no mercado. Modernas ferramentas de cermet aumentam o campo de aplicação, sendo superiores na usinagem de acabamento de aços e ferros fundidos que ferramentas de metal duro sem cobertura (RICHTER, et al., 1996) (ENDLER et al., 1994). Surge na metade da década de 50, mas somente na década de 80 é utilizada mais amplamente (TAKATSU, 1990).

O Cermet contém uma fase cerâmica e uma fase metálica (DINIZ et al., 1999) (FERRARESI, 1977). O componente cerâmico proporciona alta dureza a quente e resistência à oxidação, enquanto o componente metálico acentua a resistência ao choque térmico e a ductilidade (GRUSS, 1989), e também tem pouca tendência à difusão (MACHADO, 1988). É composto de partículas duras de TiC, TiN e/ou TiCN e geralmente o Ni como elemento de ligação (DINIZ et al., 1999) (MACHADO, 1988). Pode ocorrer também a presença de outros elementos, tais como Al, Co, Mo ou compostos de $\mathrm{Mo}_{2} \mathrm{C}, \mathrm{TaC}, \mathrm{NbC}, \mathrm{WC}, \mathrm{AlN}$, TaN e outros (MACHADO, 1988).

Suas principais aplicações são o superacabamento de aços, com altas velocidades e baixos avanços, embora também possam ser usadas nas operações de desbaste (MACHADO, 1988).

SIGL et al. (1994) apresentam o componente $\mathrm{TiB}_{2}$ e afirmam ser um promissor componente de partículas duras para operações de usinagem. $\mathrm{OTiB}_{2}$ é um material refratário com excepcional dureza em altas temperaturas e considerável estabilidade química. Apesar de sua microestrutura grosseira e aglutinante (ligas de ferro) com resistência limitada em altas temperaturas, cermets de $\mathrm{TiB}_{2}$ igualam ou ultrapassam materiais de ferramentas convencionais, particularmente quando cargas limitadas de temperatura se desenvolvem. Cermets de $\mathrm{TiB}_{2}$ combinam excelente dureza e considerável tenacidade à fratura. 
DINIZ et al. (1999) classificam o cermet como material cerâmico. Suas propriedades são intermediárias entre os cerâmicos e os metais duros (DINIZ et al., 1999) (MACHADO, 1988), sendo mais resistente ao desgaste que o metal duro (DINIZ et al., 1999). Normalmente é recomendado na usinagem de acabamento fino de aços moles (velocidades de corte bem altas) e não recomendado na usinagem de aço endurecido, pois sua dureza a quente não é suficiente (DINIZ et al., 1999).

Comparações entre cermet e metal duro:

- Cermet à base de TiC permite velocidades de corte mais altas que metal duro à base de WC devido ao TiC ser termicamente mais estável que o WC;

- A dureza do cermet TiCN é comparável à do metal duro;

- A resistência mecânica do metal duro é de 15 a $25 \%$ maior que a resistência do cermet TiCN. Como resultado a taxa de avanço e a profundidade de usinagem para o cermet devem ser bem selecionadas especialmente na operação de desbaste;

- A variação de tenacidade do cermet TiCN é menor que do metal duro, portanto, limita-se o uso deste cermet em operações de desbaste pesado. Entretanto, a resistência à fratura do cermet a base de TiC pode ser a mesma do carboneto de tungstênio-cobalto (WC-Co), quando são equivalentes o volume de ligante e o tamanho de grão do carboneto;

- A resistência ao choque térmico do cermet TiCN é menor que a do metal duro e restringe o uso de refrigerante em aplicações de desbaste.

Também existe cermet com as mesmas coberturas do metal duro. O metal duro com cobertura obtido pelo processo CVD e PVD resulta em notável aumento da resistência ao desgaste (ENDLER et al., 1994), pois as coberturas (TiC, $\mathrm{TiCN}, \mathrm{Al}_{2} \mathrm{O}_{3}$ e TiN) são mais duras e quimicamente mais estáveis que o carboneto de tungstênio (material base mais usado nos insertos) (RICHTER et al., 1996). Pela lógica, a cobertura para cermets não oferece vantagens, pois estes materiais já estão em sua composição, mas através da cobertura consegue-se suprimir a difusão e a interação entre o cavaco e a ferramenta, e melhorar o desempenho (RICHTER et al., 1996).

SAHM \& SCHNEIDER (1996) consideram o cermet com cobertura como um dos materiais de corte mais apropriados para a usinagem a seco.

Segundo RICHTER et al. (1996) e ENDLER et al. (1994), a aplicação de cobertura no cermet pelo processo CVD está usualmente associado com altas temperaturas de deposição (aproximadamente $1000^{\circ} \mathrm{C}$ ) que conduzem para formação de fases intermetálicas frágeis, e diminui a qualidade e resistência ao desgaste das camadas e da composição da camada base. Portanto reduz-se a vida da ferramenta (RICHTER et al., 1996). 
As propriedades mecânicas do metal base e da cobertura são significativamente influenciadas pelo processo de cobertura. A diminuição da resistência à ruptura transversal com o aumento da temperatura de deposição é causada muito mais pelas mudanças metalúrgicas do metal base que pela cobertura dura e frágil. Aumenta-se a temperatura de deposição e melhora a resistência à adesão mas diminui a dureza e a resistência ao desgaste (RICHTER et al., 1996).

Cermet com cobertura de $\mathrm{TiN}_{\mathrm{x}}$ obtido em baixas temperaturas pelo processo PVD tem maior resistência ao desgaste em ensaios de corte contínuo em aço com e sem liga (RICHTER et al., 1996) (ENDLER et al., 1994).

Temperaturas mais baixas de deposição são possiveis através dos processos PECVD (Plasma-Enhanced Chemical Vapour Deposition) (ENDLER et al., 1994) e PA-CVD (Plasma-Assisted Chemical Vapour Deposition Process) (RICHTER et al., 1996) (PEYRE \& DUCHATEAU, 1995) (PEYRE \& VINTERHOLLER, 1994).

ENDLER et al. (1994) ensaiam este processo com cobertura de nitreto de titânio da seguinte forma: deposita-se TiN através de uma mistura gasosa de $\mathrm{TiCl}_{4}, \mathrm{~N}_{2}, \mathrm{H}_{2}$ e ar, com temperaturas na faixa de $500-700^{\circ} \mathrm{C}$ e pressão de 330 e $450 \mathrm{~Pa}$. Um exame metalográfico revela uma camada homogênea de $\mathrm{TiN}_{\mathrm{x}}$ sem fases intermediárias na camada e com pressão de $330 \mathrm{~Pa}$ e $500-700^{\circ} \mathrm{C}$ obtém estrutura "colummar", mas com pressão de $450 \mathrm{~Pa}$ e $700^{\circ} \mathrm{C}$, obtém estrutura granular. A estrutura granular reduz a extensão de trincas e melhora a resistência ao desgaste.

Segundo RICHTER et al. (1996), para ter desempenho ótimo das ferramentas com cobertura, a temperatura assim como a composição e a espessura da cobertura têm que ser cuidadosamente ajustadas para a peça e as condições de trabalho.

\subsection{7 - Material Cerâmico}

Cerâmica é um material inorgânico e não-metálico, submetido a altas temperaturas durante sua fabricação ou uso, e segundo BAUMGARTEN (1988), sua estrutura após queima (sinterização) apresenta-se inteira ou parcialmente cristalizada. As primeiras cerâmicas a base de alumina são usadas em algumas aplicações em 1905, e patentes baseadas nesta tecnologia são publicadas na Inglaterra e Alemanha por volta de 1912 (KOMANDURI \& SAMANTA, 1989). Até a década de 80 , aplica-se somente a cerâmica a base de alumina com sucesso na industria (TRENT, 1991), e segundo DINIZ et al. (1999), somente a partir da década de 80 seu uso é mais intenso devido aos desenvolvimentos no campo das propriedades das cerâmicas e avanços na tecnologia do processo de sinterização das 
cerâmicas. As cerâmicas são usadas para aumentar significativamente a produtividade nas operações de corte (MEHROTRA, 1998).

Os materiais cerâmicos tornam-se importantíssimos na sociedade industrial moderna. Em todos os países altamente desenvolvidos (tais como Estados Unidos e Japão), a cerâmica é um dos campos de maiores investimentos, tanto financeiros como em número de pesquisas em atividade (BAUMGARTEN, 1988).

As cerâmicas são classificadas em óxidos e não-óxidos (BAUMGARTEN, 1988). Na Tabela 1 tem-se exemplos de alguns materiais cerâmicos.

Tabela 1 - Alguns exemplos de materiais cerâmicos (BAUMGARTEN, 1988)

\begin{tabular}{|c|c|c|c|}
\hline Óxidos & Nitretos & Carbonetos & Boretos \\
\hline $\mathrm{Al}_{2} \mathrm{O}_{3}$ & $\mathrm{Si}_{3} \mathrm{~N}_{4}$ & $\mathrm{WC}$ & $\mathrm{TiB}_{2}$ \\
\hline $\mathrm{Al}_{2} \mathrm{O}_{3}+\mathrm{ZrO}_{2}$ & $\mathrm{AlN}$ & $\mathrm{B}{ }_{4} \mathrm{C}$ & $\mathrm{ZrB}_{2}$ \\
\hline $\mathrm{ZrO}_{2}$ & $\mathrm{HfN}$ & $\mathrm{SiC}$ & $\mathrm{TaB}_{2}$ \\
\hline $\mathrm{TiO}_{2}$ & $\mathrm{TiN}$ & $\mathrm{TiC}$ & $\mathrm{NbB}_{2}$ \\
\hline
\end{tabular}

Aplicações de materiais cerâmicos podem normalmente aumentar a produtividade de corte dos materiais de 3 a 4 vezes acima do obtido com ferramentas convencionais de metal duro com cobertura (MEHROTRA, 1998). Existe significativo aumento da taxa de remoção de material em comparação ao metal duro na usinagem de ferro fundido, aços, superligas e materiais endurecidos (MEHROTRA, 1998). Se a máquina operatriz permite obter precisão e baixa rugosidade da peça usinada, pode-se eliminar subseqüente retificação, e a forma circular do inserto é a que obtém pior acabamento (SAMOILOV, 1990).

As propriedades interessantes da cerâmica para ferramenta de usinagem são: dureza a quente, dureza a frio, resistência ao desgaste, excelente estabilidade química, baixo coeficiente de atrito, não possui afinidade fisico-química com materiais ferrosos (dificulta a difusão) e redução da resistência à oxidação do desgaste da ferramenta em altas temperaturas de corte. E segundo KOMANDURI \& SAMANTA (1989), estas propriedades permitem usar as cerâmicas em usinagens de alta velocidade $(>300 \mathrm{~m} / \mathrm{min})$ até mesmo de metais de dificil usinagem e grandes taxas de remoção de material são possíveis com cortes ininterruptos ou setups de máquinas mais rígidos. Porém existem propriedades desfavoráveis, tais como: baixa condutividade térmica, baixa resistência ao choque térmico e principalmente baixa tenacidade (facilita trincamento e quebra da ferramenta). Segundo DINIZ et al. (1999), esta última característica restringe o uso da cerâmica no passado. A baixa resistência ao choque 
térmico depende da tenacidade à fratura, módulo de Young, coeficiente de expansão térmica e condutividade térmica (LO CASTO et al., 1993) (KOMANDURI \& SAMANTA, 1989).

Incorreta seleção e aplicação das cerâmicas podem ser a maior causa de risco de fratura prematura da ferramenta (D'ERRICO et al., 1997).

Em comparação ao metal duro, as ferramentas cerâmicas são mais refratárias e mais duras, mas possuem menor tenacidade à fratura e menor resistência à ruptura transversal.

Os processos de produção das cerâmicas consistem de dois métodos (KOMANDURI \& SAMANTA, 1989):

- Sem pressão (ou prensado a frio): o pó é moldado a verde e depois sinteriza-se para conseguir a densidade necessária;

- Com pressão: a forma é conseguida durante a sinterização de duas maneiras:

- Hot pressing: envolve aquecimento do pó dentro de uma matriz, juntamente com aplicação simultânea de uma pressão uniaxial. Embora seja mais caro, essas cerâmicas têm tamanho de grão mais fino, alta densidade e maior tensão de ruptura transversal do que produtos prensados a frio;

- Hot isostatic pressing: utiliza-se para reduzir o tamanho dos poros fechados em cerâmicas de alto desempenho. Este processo expõe produtos sinterizados ou não a um gás pressurizado aquecido.

Para produzir tenacidade razoável é importante que a cerâmica tenha um grão muito pequeno (menor que $5 \mu \mathrm{m}$ ) e sinteriza-se essencialmente até a máxima densidade, isto é, contendo menos que $2 \%$ de porosidade (TRENT, 1991). NARUTAKI et al. (1997) acrescentam a necessidade de contornos de grãos os mais puros possíveis.

Devido à sua fragilidade, deve-se tomar alguns cuidados na usinagem:

- Para evitar quebra ou lascamento da aresta de corte, os insertos possuem um chanfro na região da aresta de corte cuja dimensão varia de 0,05 a $0,3 \mathrm{~mm}$, com ângulos entre $20 \mathrm{e}$ $30^{\circ}$, sendo que o ângulo do chanfro não seja muito grande pois ele tende aumentar os esforços de corte (DINIZ et al., 1999). Segundo ROTBERG et al. (1997), ocorre aumento significativo da relação entre a força de avanço e a força de corte, principalmente com o aumento do desgaste da ferramenta;

- Ou pode realizar um microscópico arredondamento da aresta de corte (honing ou retifica) (KOMANDURI \& SAMANTA, 1989);

- Usinagem de um chanfro na peça antes de iniciar a usinagem, para que o primeiro contato ferramenta-peça seja suave; 
- Nas operações de desbaste, os insertos de cerâmica costumam ser mais espessos que os insertos de metal duro (exceto as de $\mathrm{Si}_{3} \mathrm{~N}_{4}$, por serem mais dúcteis).

As cerâmicas são usadas inicialmente com ângulo de saída negativo e aresta chanfrada, embora melhoramentos nas técnicas de fabricação, propriedades mecânicas e máquinasferramenta mais rígidas permitam um ângulo de saída positivo (KOMANDURI \& SAMANTA, 1989).

Normalmente classificam-se as ferramentas de cerâmica em duas categorias (MEHROTRA, 1998) (MACHADO, 1988): à base de alumina $\left(\mathrm{Al}_{2} \mathrm{O}_{3}\right.$ - óxido de alumínio ou corindon) e à base de nitreto de silício $\left(\mathrm{Si}_{3} \mathrm{~N}_{4}\right)$.

As cerâmicas à base de alumina geralmente têm alta resistência ao desgaste, enquanto as cerâmicas à base de nitreto de silício têm alta resistência à fratura (MEHROTRA, 1998).

A Tabela 2 lista alguns tipos de cerâmicas e suas principais composições e aplicações (MEHROTRA, 1998).

Tabela 2 - Principais cerâmicas e suas composições e aplicações (MEHROTRA, 1998)

\begin{tabular}{|c|c|c|}
\hline Tipo de Cerâmica & Composição & Aplicações \\
\hline Nitreto de Silício & $\mathrm{Si}_{3} \mathrm{~N}_{4}$ & $\begin{array}{l}\text { usinagem de desbaste de ferro fundido } \\
\text { e superligas }\end{array}$ \\
\hline Sialon & $\mathrm{Si}_{3} \mathrm{~N}_{4}+\mathrm{Al}_{2} \mathrm{O}_{3}$ & $\begin{array}{l}\text { usinagem de desbaste de ferro fundido } \\
\text { e superligas }\end{array}$ \\
\hline $\begin{array}{l}\text { Compostos de } \\
\text { Nitreto de Silício }\end{array}$ & $\mathrm{Si}_{3} \mathrm{~N}_{4}+\mathrm{TiC}, \mathrm{TiN}, \mathrm{ZrO}_{2}$, etc. & $\begin{array}{l}\text { usinagem de desbaste de ferro fundido } \\
\text { e superligas }\end{array}$ \\
\hline Whisker & $\mathrm{Al}_{2} \mathrm{O}_{3}+\mathrm{SiC}_{\mathrm{w}}$ & usinagem de acabamento de superligas \\
\hline $\begin{array}{c}\text { Preta ou } \\
\text { hot pressing }\end{array}$ & $\mathrm{Al}_{2} \mathrm{O}_{3}+\mathrm{TiC}$ & $\begin{array}{l}\text { usinagem de acabamento de aços e } \\
\text { ferro fundido; torneamento dificil }\end{array}$ \\
\hline $\begin{array}{c}\text { Branca ou } \\
\text { cold pressing }\end{array}$ & $\mathrm{Al}_{2} \mathrm{O}_{3}+\mathrm{ZrO}_{2}$ & $\begin{array}{l}\text { usinagem de acabamento de aços e } \\
\text { ferro fundido }\end{array}$ \\
\hline
\end{tabular}

Principais características das cerâmicas:

a) À BASE DE ALUMINA ( $\mathrm{Al}_{2} \mathrm{O}_{3}$ - óxido de alumínio ou corindon):

- CERÂMiCA PURA (branca ou cinza) - constituída somente de óxidos (mínimo de 98\%):

- alumina pura: finos grãos de $\mathrm{Al}_{2} \mathrm{O}_{3}$ sinterizados; pode-se ter $\mathrm{MgO}$ para inibir o crescimento de grão e óxido de cromo, titânio e níquel para aumentar a 
resistência mecânica (DINIZ et al., 1999) (MACHADO, 1988). Mas o MgO promove a fratura intercristalina e resulta em redução da resistência (NARUTAKI et al., 1997);

- alumina com baixos percentuais de óxido de zircônio $\left(\mathrm{ZrO}_{2}\right)$, que aumenta a tenacidade (DINIZ et al., 1999) (LO CASTO, et al., 1993) (TÖNSHOFF \& WOBKER, 1991), tenacidade à fratura (MEHROTRA, 1998) e resistência ao choque térmico (LO CASTO, et al., 1993). Porém a tenacidade diminui com o aumento da temperatura. A dureza também é reduzida quando aumenta o teor de $\mathrm{ZrO}_{2}$ (KOMANDURI \& SAMANTA, 1989).

Propriedades: ótima estabilidade química, baixa tenacidade, baixa dureza a quente $\mathrm{e}$ péssima resistência ao choque térmico (DINIZ et al., 1999).

Recomendações: operações de acabamento (baixa tenacidade) de peças endurecidas e ferro fundido (onde a temperatura atingida é alta e a estabilidade química dificulta o desgaste por difusão) (DINIZ et al., 1999). Geralmente exigem máquinas com alto grau de rigidez (MACHADO, 1988).

- CERÂMiCA MISTA - contém, além da alumina, carboneto de titânio (TiC) ou nitreto de titânio (TiN).

Propriedades: dureza a quente um pouco melhor (DINIZ et al., 1999) (KATSUMURA et al., 1993) (BHATTACHARYYA et al., 1989) e estabilidade química um pouco pior que a cerâmica pura (DINIZ et al., 1999); baixa tenacidade, mas melhor que a cerâmica pura (KATSUMURA et al., 1993) (TRENT, 1991). Segundo KOMANDURI \& SAMANTA (1989), a principal causa das falhas das ferramentas $\mathrm{Al}_{2} \mathrm{O}_{3}$-TiC deve-se à baixa resistência ao choque térmico. A adição de TiC melhora a resistência à fratura (MEHROTRA, 1998), melhora a resistência ao choque térmico (LO CASTO et al., 1993), melhora a resistência ao desgaste por atrito (BHATTACHARYYA et al., 1989) e reduz o desgaste por difusão (BHATTACHARYYA et al., 1989). As partículas de TiC e TiN ajudam na interrupção do movimento de deslocamento durante operações de altas velocidades de corte (LO CASTO et al., 1993).

Recomendações: torneamento de acabamento de aços endurecidos (DINIZ et al., 1999) (MACHADO, 1988), desbaste e acabamento de aços laminados (velocidade de 3 a 6 vezes maior que o metal duro) (MACHADO, 1988), acabamento e superacabamento na operação de fresamento de materiais fundidos (MACHADO, 1988). De acordo com TAKAHASHI (1998), a cerâmica branca $\mathrm{Al}_{2} \mathrm{O}_{3}$-TiC tem excelente resistência ao desgaste na usinagem de alta velocidade e segundo 
KATSUMURA et al. (1993), utiliza-se principalmente a cerâmica $\mathrm{Al}_{2} \mathrm{O}_{3}$-TiC (hot pressing) na usinagem de ferro fundido cinzento e tem poucas aplicações com outros materiais.

- CERÂMICA REFORÇADA COM "WHISKERS" - constituída por inclusões de monocristais de $\mathrm{SiC}$ ("whiskers" - 25 a $45 \%$ em volume) em uma matriz cerâmica $\left(\mathrm{Al}_{2} \mathrm{O}_{3}\right)$.

Propriedades: boas propriedades mecânicas (resistência e tenacidade) e condutividade térmica (LO CASTO, et al., 1993); segundo DINIZ et al. (1999), todas as suas propriedades têm um nível intermediário e provavelmente devido a isto, é a menos utilizada; a adição de $\mathrm{SiC}_{\mathrm{w}}$ melhora a resistência a fratura (MEHROTRA, 1998); tem melhor desempenho que as cerâmicas à base de alumina na usinagem com fluido de corte, devido ao menor coeficiente de expansão térmico (D'ERRICO et al., 1997).

Recomendações: usinagem de aços duros, aços inoxidáveis e principalmente ligas de níquel (superligas) (MACHADO, 1988).

b) À BASE DE NITRETO DE SILÍCIO $\left(\mathrm{Si}_{3} \mathrm{~N}_{4}\right)$ : cristais de $\mathrm{Si}_{3} \mathrm{~N}_{4}$ com uma fase intergranular de $\mathrm{SiO}_{2}$ sinterizados na presença da alumina (sialon) e/ou óxido de ítrio $\left(\mathrm{Y}_{2} \mathrm{O}_{3}\right)$ e manganês (MgO) (DINIZ et al., 1999) (MACHADO, 1988) (ASM, 1989b). A adição de $\mathrm{Al}_{2} \mathrm{O}_{3}, \mathrm{TiC}$, TiN, $\mathrm{ZrO}_{2}$, etc, aumenta a resistência ao desgaste (MEHROTRA, 1998). Existe a possibilidade de modificação da estrutura e da composição para obter ferramentas de corte mais produtivas (GNESIN \& YAROSHENKO, 1994).

Propriedades: combinação única de excelentes propriedades mecânicas em altas temperaturas e ótima resistência à oxidação e ao choque térmico; ótima dureza a quente; boa tenacidade; péssima estabilidade química (principalmente para metais ferrosos, segundo KONYASHIN, 1996). Com adição de $\mathrm{Al}_{2} \mathrm{O}_{3}$, TiC e TiN pretende-se o aumento da resistência ao desgaste, mas a adição de $\mathrm{Al}_{2} \mathrm{O}_{3}$ diminui a resistência à fratura (MEHROTRA, 1998). Segundo KOMANDURI \& SAMANTA (1989), em comparação ao $\mathrm{Al}_{2} \mathrm{O}_{3}-\mathrm{TiC}$, possui superior resistência de ruptura transversal e tenacidade à fratura, dobro da condutividade térmica, porém metade do coeficiente de expansão térmica, que resulta em menor sensibilidade a mudanças de temperaturas, que segundo D'ERRICO et al. (1997), proporciona um ótimo desempenho na usinagem com fluido de corte. Devido a estas excelentes propriedades mecânicas, estas ferramentas conseguem rápido crescimento em aplicações industriais (GNESIN \& YAROSHENKO, 1994).

Recomendações: usinagem de ferro fundido (cavaco curto não tende a causar difusão na superficie de saída da ferramenta); operações de desbaste, onde ocorre variação térmica 
(causada pela variação da profundidade de usinagem de peças excêntricas) ou em fresamento (resistência ao choque e tenacidade) (DINIZ et al., 1999) (MEHROTRA, 1998). A taxa de desgaste de dissolução é 16 vezes maior que do metal duro (WC), portanto, tem baixa resistência ao desgaste com aços (YAMANE et al., 1990).

MACHADO (1988) cita uma cerâmica a base de diboreto de titânio $\left(\mathrm{TiB}_{2}\right)$ (um estudo japonês), que possui excelente dureza, resistência e tenacidade em elevadas temperaturas.

Cerâmicas à base de alumina são geralmente providas de superior resistência ao desgaste e são normalmente usadas em aplicações de acabamentos, enquanto cerâmicas à base de nitreto de silício têm maior tenacidade e são aplicadas em operações de desbaste (MEHROTRA, 1998). SILVA et al. (1999) afirmam que as cerâmicas à base de alumina são mais resistentes ao desgaste de cratera que cerâmicas à base de nitreto de silício.

TAKAHASHI (1998) acrescenta que as cerâmicas à base de alumina são utilizadas na usinagem de alta velocidade de aços e materiais de baixa usinabilidade por causa de sua alta estabilidade química e térmica, propriedades estas superiores que nas ferramentas de metal duro com coberturas e cermets.

NARUTAKI et al. (1997) apresentam uma nova cerâmica de alumina que utiliza alumina em pó muito pura $(99,99 \%)$ e tamanho de grão $(0,22 \mu \mathrm{m})$ sinterizada em baixa temperatura $\left(1230^{\circ} \mathrm{C}\right)$; sem praticamente aglutinante, necessidade de hot isostatic pressing e quaisquer aditivos. Portanto o uso de grãos finos possibilita baixas temperaturas de sinterização e a não utilização de inibidores de crescimento de grãos deixa os contornos de grãos livres de impurezas. Segundo o experimento, esta nova cerâmica de alumina é mais resistente ao desgaste e a fratura (em comparação ao choque mecânico e térmico) que alumina convencional no torneamento e fresamento a seco de ferro fundido cinzento FC250-CC e aço carbono S45C (ou AISI 1045).

\subsection{8 - Nitreto Cúbico de Boro Policristalino (PCBN)}

Nitreto cúbico de boro é o material mais duro depois do diamante. A General Eletric Co. (USA) produz com sucesso pela primeira vez em 1957. Desenvolve-se sua sintetização após a obtenção do diamante artificial. Obtém-se este material sintético pela seguinte reação química (DINIZ et al., 1999) (HEATH, 1989):

$$
\mathrm{BCl}_{4}+\mathrm{NH}_{3} \rightleftarrows \mathrm{BN}+3 \mathrm{HCl}
$$


$\mathrm{O}$ composto $\mathrm{BN}$ tem estrutura cúbica hexagonal (similar à grafite, com números aproximadamente iguais de átomos de boro e nitrogênio, organizados alternadamente) e pode transformar-se em estrutura cúbica, conhecida como CBN (similar ao diamante), como ocorre com o carbono, através de um processo com pressões de 5000 a $9000 \mathrm{MPa}$ e temperaturas de 1500 a $1900^{\circ} \mathrm{C}$, na presença de um catalisador (geralmente o lítio).

A General Eletric Co. também produz as primeiras plaquetas (blanks) de PCBN em meados dos anos 70 sob o nome comercial de Borazon Compact ${ }^{\mathrm{TM}}$, através da sinterização de uma camada de $0,5 \mathrm{~mm}$ de espessura de partículas de nitreto cúbico de boro com a presença de uma fase ligante, simultaneamente fixada sobre uma base de metal duro. Estas plaquetas são posteriormente soldadas a um inserto intercambiável de metal duro ou soldados diretamente a um porta ferramentas de aço (DINIZ et al., 1999) (MACHADO, 1988).

Atualmente existe uma linha de pesquisa para depositar coberturas de PCBN em metal duro pelo processo CVD. A fabricante Sandvik oferece um tipo de cobertura PCBN, resultado de três anos de testes em aplicações selecionadas. A técnica é comprimir a camada de PCBN no inserto de metal duro bruto durante o processo de sinterização, obtendo camada de 1,016 a $2,032 \mathrm{~mm}$ de profundidade. Este tipo de ferramenía : $:=\mathrm{m}$ bom desempenho no torneamento de peças endurecidas, usinagem de ferro fundido e ligas de alta temperatura comumente usadas na industria aeroespacial. O principal benefício desta camada sinterizada é a segurança da aresta de corte, pois normalmente aplicações de PCBN envolvem muito calor, que no caso de PCBN soldado, pode amolecer a solda o suficiente para lascar ou quebrar repentinamente o PCBN (KOELSCH, 2000).

Comercialmente existem diferentes tipos de PCBN, cada fabricante utiliza diferentes materiais de segunda-fase, distribuição de tamanho de partículas e concentração de partículas finas de CBN. Portanto, é dificil generalizar propriedades mecânicas, técnicas de fabricação e desempenho em usinagem (HEATH, 1989). Entretanto pode-se dividir os PCBNs em duas amplas categorias, segundo suas aplicações (DINIZ et al., 1999) (HEATH, 1989):

- usinagem de desbaste ( $a_{p}$ entre 0,5 e $8 \mathrm{~mm}$ ):

- maior concentração de nitreto cúbico de boro ( $90 \%$ em volume), aumenta a ligação cristal com cristal e conseqüentemente aumenta sua tenacidade;

- devido à alta concentração de CBN não é interessante quando $\mathrm{a}_{\mathrm{p}}<0,5 \mathrm{~mm}$;

- maior dureza entre os PCBNs devido ao alto teor de nitreto cúbico de boro;

- eficiência quando o mecanismo predominante de desgaste é a abrasão e/ou quando ocorrem grandes forças de corte ou corte interrompido, como torneamento e fresamento de ferro fundido cinzento (dureza entre 45 a $65 \mathrm{HRc}$ ); 
- não possuem boas características químicas e térmicas, comparadas às cerâmicas.

- usinagem de acabamento $\left(\mathrm{a}_{\mathrm{p}}<0,5 \mathrm{~mm}\right)$ :

- adição de uma fase cerâmica, em conseqüência possui menor tenacidade e dureza, mas melhor estabilidade química e térmica que PCBNs de desbaste;

- apesar de menores tenacidade e dureza, consegue-se manter a integridade da aresta de corte, obtendo tolerâncias apertadas e bom acabamento superficial ao longo da vida da ferramenta.

Características básicas do PCBN:

- química e termicamente mais estável que o diamante, podendo usinar ligas ferrosas (HEATH, 1989);

- baixa condutividade elétrica (HEATH, 1989);

- altos valores de condutividade térmica (HEATH, 1989);

- tenacidade similar ao material cerâmico baseado em nitretos e cerca de duas vezes a da alumina;

- dureza somente superada pelo diamante, sendo duas vezes a dureza da alumina;

- em operações de acabamento, a resistência ao desgaste do PCBN aumenta com a redução do teor de $\mathrm{CBN}$ e as velocidades de corte são superiores em operações de desbaste (HEATH, 1989).

Geralmente as ferramentas de PCBN são empregadas na usinagem de: aços duros (45 a 65 HRc) em condições difíceis, tais como corte interrompido; aços ferramentas; aços rápidos; ligas ferrosas resistentes a altas temperaturas a base de níquel e cobalto; metais duros e revestimentos duros com altas porcentagens de carboneto de tungstênio ou $\mathrm{Cr}-\mathrm{Ni}$, aplicadas por soldagem de deposição ou jato de material liquefeito por chama.

Segundo DINIZ et al. (1999), alguns cuidados devem ser tomados na utilização de ferramentas de PCBN:

- não utilizar PCBN em materiais fáceis de serem usinados com outros materiais de ferramenta;

- maior rigidez possível do sistema máquina-ferramenta-dispositivo de fixação-peça;

- geometria da ferramenta deve ser negativa (normalmente $\gamma=-5^{\circ}$ ) para garantir resistência aos choques, com ângulo de folga $\alpha=5$ a $9^{\circ} \mathrm{e}$ o maior ângulo possivel lateral de posição (no mínimo $15^{\circ}$ ) para minimizar trincas na aresta;

- aresta de corte chanfrada $\left(0,1 \mathrm{~mm}\right.$ x 20 a $\left.45^{\circ}\right)$, para direcionar os esforços de corte para o centro da ferramenta e, assim, diminuir a possibilidade de quebra da aresta. 
Utilização de fluido de corte:

- segundo DINIZ et al. (1999), sempre que possível utilizar fluído de corte, com exceção do ferro fundido;

- segundo HEATH (1989), geralmente para operações de desbaste não é necessário fluido de corte e não é recomendado para fresamento. Embora em operações de acabamento recomenda-se refrigeração abundante, onde aumenta ligeiramente a vida da ferramenta com relação ao desgaste de flanco $\mathrm{V}_{\mathrm{B}}$.

Segundo MACHADO (1988), a limitação da aplicação do PCBN é seu alto custo de fabricação, tendo preço médio de mercado em torno de US\$ 150 cada unidade (cerca de 30 vezes o preço do metal duro e de 3 a 5 vezes o da cerâmica).

\section{3 - AVARIAS E DESGASTES DA FERRAMENTA}

Materiais metálicos possuem irregularidades em suas superficies, conhecidas como erros microgeométricos ou rugosidade, na forma de picos e vales. Na interface entre dois materiais, criam-se minúsculas áreas de contato e no caso de duas superficies metálicas a transmissão de calor entre elas aumenta à medida que aumenta esta área de contato (AGOSTINHO et al., 1977). Quando existe movimento relativo ocorre perda de material de ambas as superficies, normalmente na de menor dureza a perda é mais pronunciada. Na usinagem dos metais a ação de corte e o atrito do cavaco contra a ferramenta aumentam a temperatura na interface, o que acelera os processos físicos e químicos associados ao desgaste da ferramenta. Com o desgaste, a geometria da ferramenta tende mudar. Esta mudança de geometria tem influência na força de corte, na potência consumida, no acabamento superficial obtido, na acuracidade dimensional e na estabilidade dinâmica do processo (com a ferramenta gasta aparece chatter no processo, isto é, vibrações leves).

Para uma ferramenta de corte, a perda de material é indesejável e deve ser minimizada. Portanto é conveniente conhecer como se processa o desgaste, a fim de evitá-lo. Como no processo de usinagem existe uma geração intensa de calor, a temperatura tem grande importância no desgaste da ferramenta. A temperatura do material da ferramenta na zona onde ocorre o desgaste é determinada pela diferença entre a taxa de energia térmica gerada e taxa de energia térmica dissipada. A dissipação da energia é uma função das propriedades termo-condutivas do material da ferramenta e do material da peça (KENDALL, 1989). O desenvolvimento e a seleção básica de materiais de ferramenta são baseados na sua 
habilidade de manter a dureza, tenacidade e a estabilidade química a altas temperaturas. Mesmo os melhores materiais para ferramenta podem ter suas propriedades modificadas com o aumento da temperatura.

A Figura 2 mostra uma vista da formação de cavaco com condições de tensão e deformação presentes no material e no cavaco. O desgaste da ferramenta de corte está localizado sobre as superfícies específicas onde tensão, deformação, velocidade e temperatura estão acima dos níveis críticos. É importante entender onde estas condições críticas existem e como elas interagem para causar o desgaste da ferramenta (KENDALL, 1989).

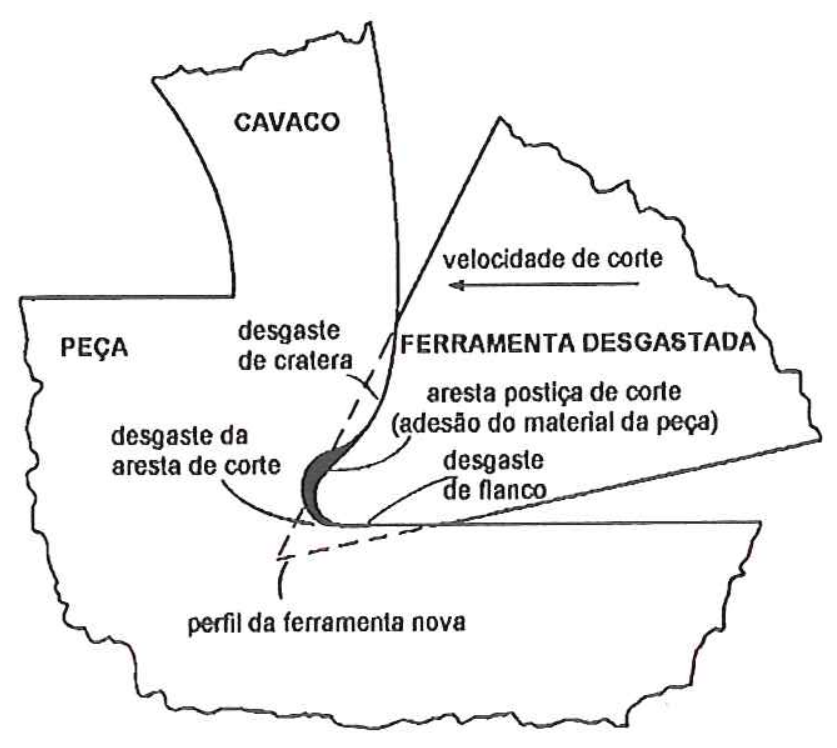

Figura 2 - Superfícies típicas de desgaste (KENDALL, 1989)

\subsection{1 - Temperatura de Corte}

Experimentalmente, verificou-se que de 87 a $90 \%$ de todo o trabalho de usinagem transformam-se em calor (FERRARESI, 1977). Segundo TRENT (1991), o trabalho realizado na formação de cavaco e o movimento do cavaco e da superfície recém usinada sobre a ferramenta é quase totalmente convertido em calor, por causa do valor muito alto de tensão plástica, é improvável que mais que $1 \%$ do trabalho realizado seja armazenado como energia elástica, os restantes $99 \%$ são convertidos em calor para o cavaco, a ferramenta e a peça. Portanto, DINIZ et al. (1999) e TRENT (1991) afirmam que praticamente toda a energia mecânica associada à formação do cavaco se transforma em energia térmica. Os efeitos de formação e transmissão do calor no corte de metais são muitos complexos, pois ocorrem mudanças nas características físicas e mecânicas dos metais (FERRARESI, 1977). 
Para TRENT (1991) muitos dos problemas econômicos e técnicos de usinagem são causados diretamente ou indiretamente pela ação do calor.

O calor é primeiramente reconhecido por F. W. Taylor em 1907 em seu artigo "On the art of cutting metals", no desenvolvimento de novos aços rápidos (TRENT, 1991).

Segundo DINIZ et al. (1999) e FERRARESI (1977), as principais fontes de calor no processo da formação do cavaco em ordem decrescente de geração são devidas: a) à deformação plástica e ao cisalhamento do cavaco na região de cisalhamento; b) ao atrito do cavaco com a superfície de saída da ferramenta e c) ao atrito da superfície da peça com a superfície de folga da ferramenta.

A quantidade de calor produzida é dissipada através do cavaco, da peça, da ferramenta, do meio ambiente e do fluido de corte. As porcentagens de calor dependem do tipo de usinagem, do material da peça e da ferramenta, das condições de usinagem e da forma da ferramenta (DINIZ et al., 1999) (FERRARESI, 1977).

Segundo TRENT (1991), para cavacos contínuos a mais importante fonte de calor responsável pelo aumento de temperatura da ferramenta é identificada na região de zona de fluxo onde o cavaco está aderido à superfície de saída da ferramenta. A quantidade de calor necessária para aumentar a temperatura da camada fina da zoria de fluxo é uma pequena fração da energia total consumida na usinagem, e o volume de metal aquecido na zona de fluxo varia consideravelmente. Então, não há relação direta entre forças de corte ou potência consumida e a temperatura próxima à aresta de corte.

O calor dissipado pela ferramenta é pequeno e diminui aumentando a velocidade de corte. Porém como a região da ferramenta que recebe este calor (região de contato ferramenta-peça e cavaco-ferramenta) é reduzida e não muda com o tempo, como acontece com a peça, desenvolvem-se altas temperaturas (até $1200^{\circ} \mathrm{C}$ - Figura 3) contribuindo para o desgaste da ferramenta (DINIZ et al., 1999) (FERRARESI, 1977).
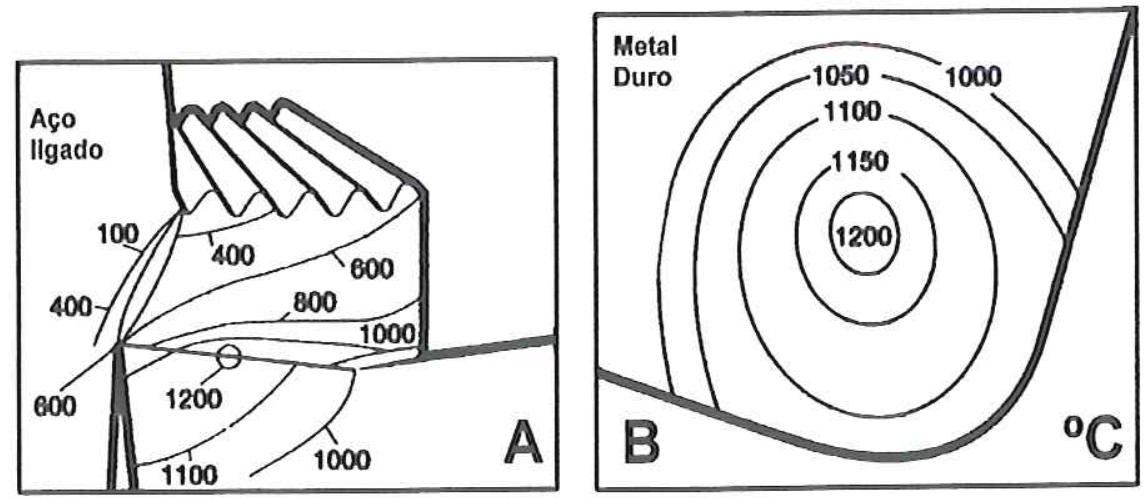

Figura 3 - Distribuição de temperatura na ponta de uma ferramenta de metal duro (DINIZ et al., 1999) 
Segundo FERRARESI (1977), o calor produzido se distribui de forma irregular, conforme observa-se na Figura 3; grande parte do calor é recebida pelo cavaco, menor parte pela peça e ainda menor pela ferramenta; a geração de calor aumenta com o aumento da velocidade de corte, avanço e profundidade de corte; nos regimes de corte altos, o atrito é a fonte básica de calor; no torneamento maior parte do calor vai para o cavaco e na furação maior parte vai para a peça.

Atualmente para aumentar a produtividade da ferramenta deve-se aumentar a velocidade de corte, o avanço e a profundidade de corte, sendo que estes três fatores aumentam a temperatura. Portanto, há necessidade de se empregar matérias para ferramentas mais resistentes a altas temperaturas e ao desgaste, além de tentar diminuir a temperatura de corte através de fluido de corte, onde for possível (FERRARESI, 1977).

Na Tabela 3 tem-se a temperatura do ponto de amolecimento de alguns materiais para ferramentas (ASM, 1989a).

Tabela 3 - Ponto de amolecimento de alguns materiais para ferramenta

\begin{tabular}{|c|c|}
\hline Material da Ferramenta & Ponto de Amolecimento $\left({ }^{\circ} \mathbf{C}\right)$ \\
\hline Aço Rápido & 600 \\
\hline Metal Duro (WC) & 1100 \\
\hline Óxido de Alumínio & 1400 \\
\hline Nitreto Cúbico de Boro & 1500 \\
\hline Diamante & 1500 \\
\hline
\end{tabular}

\subsection{2 - Mecanismos de desgaste da ferramenta}

O desgaste de uma ferramenta de corte é um dos mais importantes fatores que definem a eficiência, estado das superfícies das peças usinadas, precisão e características de desempenho dos elementos de máquinas (KLIMENKO et al., 1992).

O processo detalhado pelo qual o desgaste de uma ferramenta ocorre durante a usinagem é extremamente complexo e o desgaste observado não pode ser explicado por somente um mecanismo de desgaste (VLEUGELS \& VAN DER BIEST, 1998).

Portanto, o desgaste das ferramentas de corte ocorre devido a determinados mecanismos de desgaste, que se manifestam de formas distintas e dificilmente o desgaste de uma ferramenta é proveniente de apenas um único mecanismo, mas sim de uma combinação 
deles. Segundo MEHROTRA (1998), os mecanismos de desgaste são devidos às altas temperaturas e pressões geradas na aresta de corte.

Para VLEUGELS \& VAN DER BIEST (1998), os mecanismos de desgaste são: abrasão, deformação plástica, delaminação, adesão, instabilidade química, reação química e tribooxidação. Note que deformação plástica é classificada como tipo de avaria no item 2.3.3. Na literatura ocorre muita discordância na classificação dos diversos desgastes, avarias e mecanismos de desgaste.

DINIZ et al. (1999) simplificam os mecanismos de desgaste principais em cinco tipos: aresta postiça de corte; abrasão mecânica; aderência; difusão e oxidação. Mas na realidade o desgaste é uma combinação de processos mecânicos e químicos (dissolução e difusão) (SILVA et al., 1998) (VLEUGELS \& VAN DER BIEST, 1998).

O tipo e contribuição relativa destes diferentes mecanismos no desgaste total da ferramenta de corte esta relacionado com as propriedades mecânicas e químicas da ferramenta e do material da peça, como também da fase ligante da ferramenta, sistema da máquina ferramenta-ferramenta, condições de usinagem e características da formação do cavaco (VLEUGELS \& VAN DER BIEST, 1998). E dentre os parâmetros de condições de usinagem, segundo LIM et al. (1995), o avanço e a velocidade de corte são os mais importantes nos mecanismos de desgaste.

A seguir a descrição dos mecanismos de desgaste:

\section{a) Aresta Postiça de Corte:}

Muitas vezes, na usinagem, forma-se na superfície de contato entre o cavaco e a superfície de saída da ferramenta, sucessivas camadas do material da peça que se soldam devido à alta temperatura e alta pressão, sendo posteriormente endurecidas devido ao encruamento. A dureza da aresta postiça de corte corresponde à do material temperado (TRENT, 1991) (FERRARESI, 1977). Segundo TRENT (1991), é uma estrutura dinâmica e não é observada em metais puros, mas ocorre freqüentemente em condições industriais. Forma-se com cavaco contínuo ou descontínuo, por exemplo na usinagem de aço e ferro fundido (TRENT, 1991). Em baixas velocidades de corte, a parte inferior do cavaco em contato com a ferramenta, sob pressão de corte na zona de aderência, mantém este contato sem movimento relativo o tempo suficiente para se soldar à ferramenta, separa-se de outras porções de cavaco e permanece presa à superfície de saída (DINIZ et al., 1999). Esta camada modifica o comportamento da aresta de corte com relação à força de corte, acabamento superficial da peça e desgaste da ferramenta (DINIZ et al., 1999). A aresta postiça de corte tende a crescer gradualmente até certo ponto quando rompe 
bruscamente, fraturando a ponta ou levando partículas da superficie de folga da ferramenta, parte é carregada com o cavaco e parte é aderida à peça.

Com a aresta postiça de corte ocorre grande desgaste frontal, a superfície de saída da ferramenta é protegida (não ocorre desgaste de cratera) e a força de corte diminui.

A partir de uma velocidade de corte quando a temperatura de corte é maior que a temperatura de recristalização do material, não forma mais a aresta postiça de corte, não ocorre encruamento dos novos grãos de cavaco. Esta velocidade de corte chama-se velocidade crítica. Portanto para diminuir a velocidade crítica é necessário aumentar a temperatura do processo, tal como, aumentar o avanço e a profundidade de corte, diminuir os ângulos de saída e de inclinação, retirar refrigeração, etc. À medida que a ductilidade do material diminui, os cavacos são mais curtos e decresce a formação de aresta postiça de corte (DINIZ et al., 1999) (FERRARESI, 1977).

b) Abrasão Mecânica:

Uma das principais causas de desgaste frontal e de cratera da ferramenta (DINIZ et al., 1999). Tem ação mais proeminente no desgaste frontal, pois a superfície de folga atrita com um elemento rígido (peça), enquanto que a superfície de saída atrita com um elemento flexível (cavaco). A abrasão mecânica ocorre pela presença de partículas duras do material da peça (como carbonetos) e pelo aumento da temperatura de corte, que reduz a dureza da ferramenta; este aumento de temperatura está relacionado ao aumento da velocidade de corte e do avanço. Segundo FERRARESI (1977), este desgaste depende principalmente da relação das durezas da ferramenta e do material em dadas condições de usinagem, da quantidade e da distribuição das microimpurezas duras do material usinado, do seu estado de encruamento e outros. Portanto um material para ferramenta resistente a abrasão mecânica deve ter alta dureza à quente, alto ponto de fusão e alta condutividade térmica.

\section{c) Aderência:}

Forma-se um extrato metálico aderente entre duas superfícies em contato sob cargas moderadas, baixas temperaturas e baixas velocidades de corte. Na separação dessas duas superfícies, devido à alta resistência do extrato, ocorre ruptura em uma das superfícies (DINIZ et al., 1999) (DIXON \& WRIGHT, 1985). Este fenômeno está presente na aresta postiça de corte e é muito importante na formação do desgaste de entalhe, pode também ser acelerado dependendo da afinidade química entre os materiais da peça e da ferramenta. Geralmente, a zona de escorregamento, o corte interrompido, profundidade de corte irregular ou falta de rigidez promovem o fluxo irregular de cavaco, facilitando o mecanismo de desgaste por aderência. Para diminuir este fenômeno deve-se utilizar 
adequadamente um fluido de corte (na função de efeito lubrificante) e recobrimento da ferramenta com material de baixo coeficiente de atrito como o nitreto de titânio (DINIZ et al., 1999).

d) Dissolução:

Tendência química do material da ferramenta decompor-se no material usinado. Este mecanismo de desgaste precede a difusão (JINDAL et al., 1999).

e) Difusão:

A difusão entre ferramenta e cavaco é um fenômeno microscópio e está relacionada à afinidade físico-química entre o material da ferramenta e o material da peça, a alta temperatura, alta pressão e duração de contato. Altas temperaturas de corte possibilitam a difusão de elementos químicos entre a peça e a ferramenta, e mudam as características de ambas. A difusão é responsável principalmente pelo desgaste de cratera em altas velocidades de corte, pois na superfície de saída da ferramenta têm-se as condições necessárias para a difusão (alta temperatura e tempo de contato cavaco-ferramenta). A difusão normalmente não ocorre em ferramentas de aço rápido (devido às baixas velocidades de corte), de material cerâmico (não tem afinidade físico-química com materiais ferrosos) e de metal duro com cobertura de $\mathrm{Al}_{2} \mathrm{O}_{3}$.

Exemplos de difusão: a forma mais comum é a difusão dos elementos de liga ou do carbono da peça para a ferramenta e vice-versa, resultando na formação de cratera na superfície de saída da ferramenta. Por exemplo, a grafitização das ferramentas de diamante, quando submetidas a temperaturas moderadas (em torno de $600{ }^{\circ} \mathrm{C}$ ) na usinagem de materiais que reagem com carbono (DINIZ et al., 1999) (KÖNIG \& NEISES, 1993). Outro exemplo típico é a difusão dos átomos de ferro do aço do cavaco para a ferramenta de metal duro (DINIZ et al., 1999).

\section{f) Oxidação:}

A alta temperatura mais o oxigênio presente no ar e água (dos fluidos de corte) significa oxidação para a maioria dos materiais metálicos usinados. O tungstênio e o cobalto formam um filme de óxido poroso sobre a ferramenta, os quais são frágeis e são arrastados facilmente pelas superficies em atrito, gerando desgaste, porém alguns óxidos como os óxidos de alumínio são muito mais resistentes e duros. $\mathrm{O}$ desgaste normalmente ocorre nas extremidades do contato cavaco-ferramenta devido ao acesso do ar nesta região, sendo uma possível explicação para o desgaste de entalhe (DINIZ et al., 1999). 


\subsection{3 - Tipos de avarias e desgastes da ferramenta}

Desgastes das ferramentas são aqueles que ocorrem na superfície de saída e de folga da ferramenta e avarias das ferramentas ocorrem na aresta de corte durante a usinagem (FERRARESI, 1977).

Existem diversos tipos de avarias e desgastes das ferramentas de corte, os principais são mostrados na Figura 4:

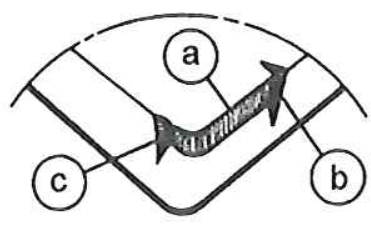

a) Desgaste Frontal

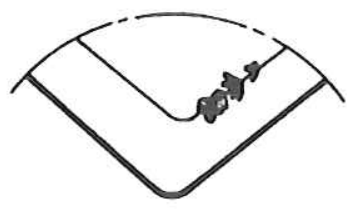

d) Lascamento

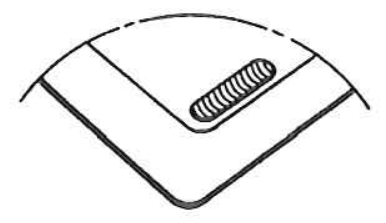

b) Desgaste de Cratera

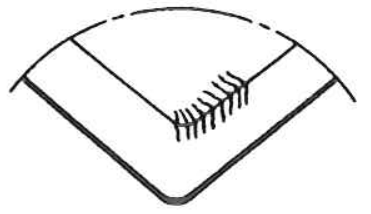

origem térmica

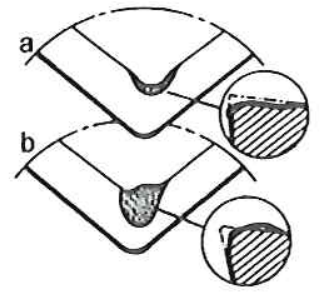

c) Deformação Plástica da Aresta de Corte

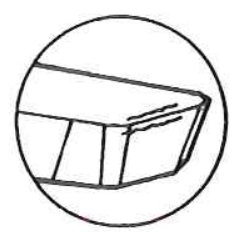

origem mecânica

e) Trincas

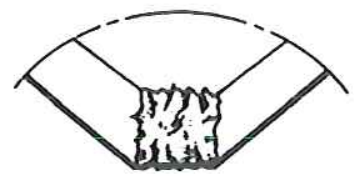

f) Quebra da Ferramenta

Figura 4 - Alguns dos tipos de avarias e desgastes mais comuns (DINIZ et al., 1999)

\section{a) Desgaste Frontal (ou de flanco) (Figura 4a):}

É um desgaste progressivo que ocorre na superfície de folga da ferramenta, por causa do contato ferramenta e a superfície da peça recém usinada. É o tipo de desgaste mais comum, e todo processo de usinagem causa este desgaste (DINIZ et al., 1999). O mecanismo de desgaste predominante é a abrasão mecânica (GRAHAM, 1994). As partículas duras do material da peça, que permanecem sobre a superfície usinada, são pressionadas contra o flanco da ferramenta atuando como um rebolo. Quando o desgaste de flanco é acentuado, pode ocorrer um aumento de temperatura levando ao desgaste químico ou oxidação. $\mathrm{O}$ desgaste indicado pela letra a é o desgaste rápido de flanco que 
causa acabamento superficial de má qualidade ou fora de tolerância. A principal causa para o desgaste de flanco é velocidade de corte muito alta ou resistência ao desgaste insuficiente (MARCONDES, 1990).

b) Desgastes de entalhe (Figura 4a):

São desgastes do tipo entalhe que causam acabamento superficial de má qualidade e risco de quebra da aresta, indicados pelas letras b e c no esquema de desgaste de flanco. Para esse tipo de desgaste as causas são: b/c - oxidação e/ou atrito e $\mathbf{c}$ - oxidação. Geralmente para solucionar estes problemas é necessário reduzir a velocidade de corte, aumentar a resistência ao desgaste da ferramenta e/ou selecionar material para ferramenta com cobertura de $\mathrm{Al}_{2} \mathrm{O}_{3}$. Com relação ao material da ferramenta, para minimizar o desgaste é indicado o PCBN (para matérias ferrosos), o PCD (para materiais não ferrosos) e as cerâmicas reforçadas.

c) Desgaste de Cratera (Figura 4b):

É um desgaste que ocorre na superfície de saída da ferramenta, causada pelo atrito entre a ferramenta e o cavaco. Esta excessiva craterização causa o enfraquecimento da aresta de corte. $\mathrm{O}$ crescimento do desgaste de cratera gera a quebra da ferramenta, quando se encontra com o desgaste frontal (DINIZ et al., 1999). A principal causa é a difusão, devido a temperaturas de corte muito altas na superfície de saída. A cratera também pode ser formada pela ação de partículas endurecidas, de acordo com mecanismo de desgaste por abrasão mecânica. PEYRE \& VINTERHOLLER (1994) dizem que é resultado de pressões elevadas. Excessivo desgaste de cratera muda a geometria da aresta de corte e pode influenciar na formação do cavaco, mudando o ângulo do plano de cisalhamento, a direção das componentes da força de usinagem e também enfraquece a aresta de corte. Não ocorre em todos os processos de usinagem, principalmente quando se utilizam ferramentas de metal duro com cobertura de $\mathrm{Al}_{2} \mathrm{O}_{3}$ ou cerâmica. Para solucionar esse desgaste deve-se selecionar uma ferramenta com cobertura de $\mathrm{Al}_{2} \mathrm{O}_{3}$ ou cerâmica, geometria positiva e reduzir primeiro a velocidade de corte para obter uma temperatura mais baixa, depois reduzir o avanço. Se a cratera localizar-se próxima a aresta, o aumento do avanço afasta a cratera da região da aresta de corte.

d) Deformação Plástica da Aresta de Corte (Figura 4c):

São depressões da aresta (a) ou impressões no flanco (b), sendo resultado da combinação de alta temperatura com alta pressão de corte ou força de avanço sobre a aresta (MARCONDES, 1990). Altas velocidades de corte, avanço elevado e o material da peça endurecido são os maiores responsáveis. A formação de uma saliência sobre a aresta de corte tem efeito sobre a temperatura de corte, a geometria da ferramenta, o fluxo do 
cavaco, o desgaste de flanco e o acabamento superficial da peça, e pode conduzir à quebra da aresta. Esta avaria é evitada quando emprega uma ferramenta com alta dureza a quente e grande resistência à deformação plástica, ou pela mudança das condições de usinagem e/ou geometria da ferramenta, visando a diminuição dos esforços e da temperatura de corte (DINIZ et al., 1999). O PCBN é a melhor opção para materiais ferrosos e o PCD para não ferrosos.

e) Lascamento (Figura 4d):

É um tipo de avaria da ferramenta que se diferencia do desgaste de flanco e de cratera, pois estes retiram continuamente partículas muito pequenas da ferramenta e no lascamento, partículas maiores são retiradas de uma só vez (DINIZ et al., 1999). Pode ocorrer ao longo da aresta principal de corte. Tais lascamentos aparecem mais freqüentemente quando a aresta de corte remove o cavaco intermitentemente. Isto resulta em ciclos de impacto e de carregamento térmico na aresta de corte. Estes dois estados de carregamento cíclico podem iniciar pequenas trincas e então propagar estas trincas ou outras trincas residuais para formar lascas. Ocorrem principalmente em ferramentas com material frágil e/ou quando a aresta de corte é pouco reforçada. Esta avaria prejudica o acabamento superficial da peça, aumenta o desgaste de flanco, e pode provocar a quebra da ferramenta. Para solucionar deve-se selecionar classe de metal duro mais tenaz, escolher aresta de corte mais robusta, aumentar a velocidade de corte ou escolher geometria mais positiva.

f) Trincas Térmicas (Figura 4e):

É um tipo de avaria da ferramenta causada pela variação da temperatura e/ou esforços mecânicos. As trincas de origem térmica ocorrem perpendicularmente à aresta de corte, já as trincas de origem mecânica são paralelas à aresta (DINIZ et al., 1999). Alguns fatores que causam estas trincas são: corte interrompido, acesso irregular do fluido de corte, variação da espessura de corte (típica do fresamento) e solda do inserto no porta ferramenta. O crescimento das trincas pode levar a quebra da ferramenta. Para solucionar deve-se escolher uma ferramenta mais tenaz com melhor resistência aos choques térmicos, utilizar fluido de corte em abundância ou eliminá-lo por completo, diminuir o avanço por dente e posicionar a fresa corretamente em relação à peça.

g) Quebra da Ferramenta (Figura 4f):

Todos os desgastes e avarias ao crescerem podem gerar a quebra da ferramenta. Mas algumas vezes, a quebra pode ocorrer inesperadamente devido a alguns fatores: ferramenta muito dura, carga excessiva, raio de ponta, ângulo de ponta ou ângulo de cunha pequeno, corte interrompido, parada instantânea do movimento de corte, 
entupimento dos canais de expulsão de cavacos ou dos bolsões de armazenamento dos cavacos (fresamento), etc (DINIZ et al., 1999) (FERRARESI, 1977). A quebra da ferramenta é muito prejudicial, pois pode danificar todo o inserto, o porta ferramentas e a própria peça.

Para o desgaste de flanco progressivo, a relação entre o desgaste da ferramenta e o tempo segue um modelo fixo (MILLS \& REDFORD, 1983):

- Desgaste Primário: inicialmente, com uma ferramenta nova, a taxa de desgaste da ferramenta é alta. O tempo de ação desta taxa de desgaste é dependente, entre outros fatores, das condições de corte e do material da peça. O tempo para produzir este desgaste primário reduz com o aumento da velocidade de corte;

- Desgaste Secundário: estágio seguido do desgaste primário, quando a taxa de aumento do desgaste de flanco é praticamente constante. Esta taxa de desgaste é consideravelmente menor que a taxa de desgaste primário numa mesma faixa de velocidade de corte;

- Desgaste Terciário: no fim do estágio de desgaste secundário, quando o desgaste de flanco é considerável e está muito longe do recomendado conno critério para falha da ferramenta, as condições são tais que começa um novo estágio de desgaste, conduzindo rapidamente à quebra da ferramenta.

O desgaste de cratera, normalmente medido em termos da profundidade da cratera, aumenta progressivamente com o tempo até um ponto, quando a cratera enfraquece suficientemente a aresta e, pela ação das forças sobre a mesma, ocorre a quebra (MILLS \& REDFORD, 1983).

\subsection{4 - Medição dos desgastes da ferramenta}

Convencionou-se medir os desgastes no plano ortogonal da ferramenta (DINIZ et al., 1999) (LIM et al., 1995) (KENDALL, 1989). Os desgastes são (Figura 5):

- Superficie de saída: profundidade de cratera (KT), largura da cratera (KB) e distância do centro da cratera à aresta de corte $(\mathrm{KM})$;

- Superficie de folga: largura do desgaste de flanco ( $\mathrm{V}_{\mathrm{B}}$, valor médio), largura máxima do desgaste de flanco $\left(\mathrm{V}_{\mathrm{Bmax}}\right)$ e desgaste de entalhe $\left(\mathrm{VB}_{\mathrm{N}}\right.$ e $\left.\mathrm{VB}_{\mathrm{C}}\right)$. 


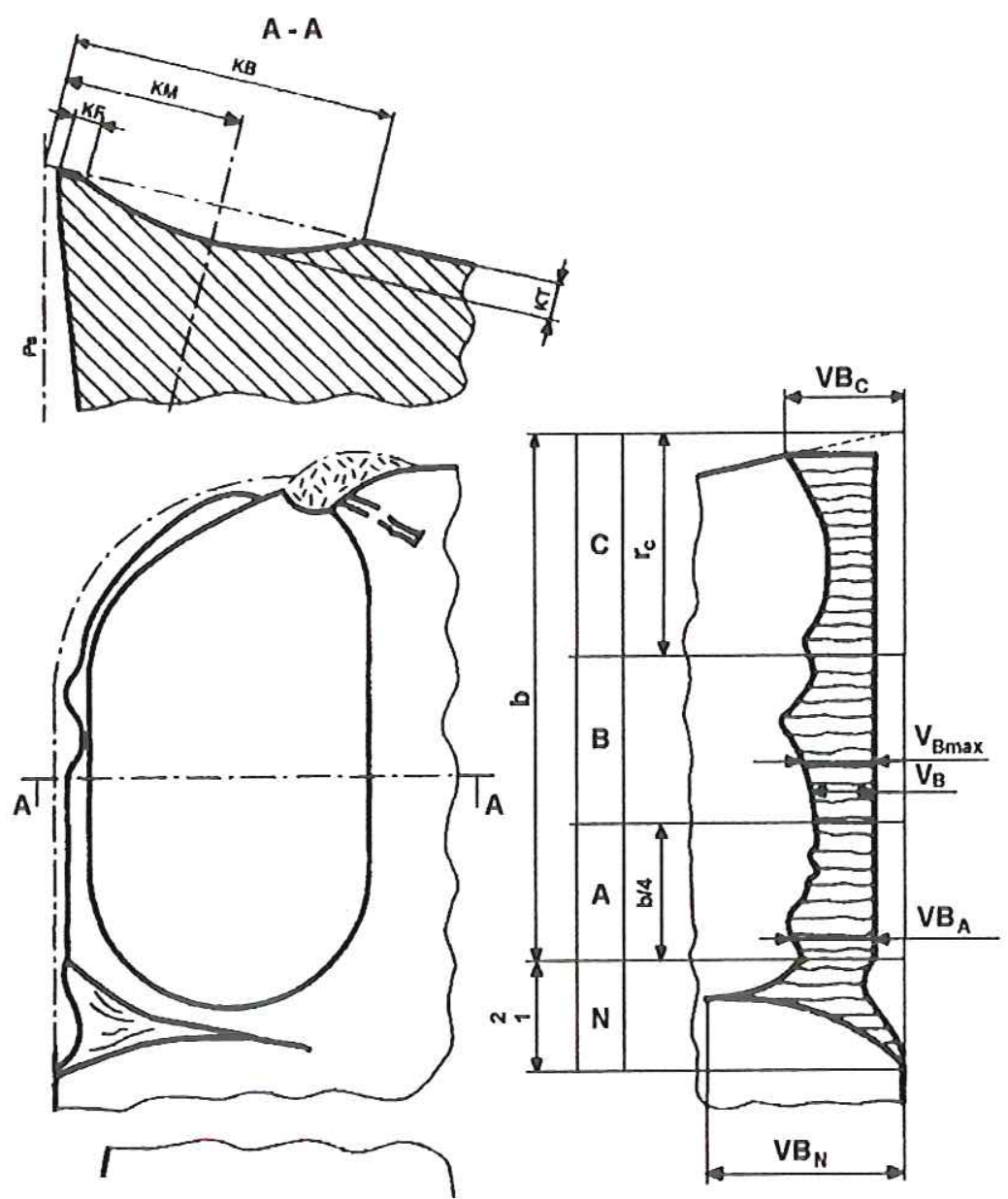

Figura 5 - Medição dos desgastes da ferramenta (DINIZ et al., 1999)

\section{4 - DESGASTE E VIDA DA FERRAMENTA}

Vida da ferramenta é o tempo que a mesma trabalha efetivamente (deduzidos tempos passivos) até perder sua capacidade de corte, dentro de um critério previamente estabelecido (DINIZ et al., 1999) (FERRARESI, 1977).

Normalmente os critérios de fim de vida da ferramenta são: desgastes excessivos na aresta de corte, levando a quebra da ferramenta e/ou aumento da temperatura na aresta de corte da ferramenta; desgaste $V_{B}$ na superfície de folga da ferramenta, dificultando obtenção de tolerâncias apertadas e bons acabamentos superficiais e/ou aumento da força de usinagem (DINIZ et al., 1999) (FERRARESI, 1977).

$\mathrm{Na}$ usinagem com ferramentas de aço rápido, o fim de vida da ferramenta é devido principalmente a diminuição de sua dureza com o aumento da temperatura (DINIZ et al., 1999) (FERRARESI, 1977). 
As ferramentas de metal duro com cobertura apresentam um desgaste de flanco $V_{B}$ lento até valores da ordem de 0,3 a $0,4 \mathrm{~mm}$. A partir deste momento, as camadas de cobertura desgastam-se quase que totalmente, então o corte é realizado pelo substrato da ferramenta que é bem menos resistente ao desgaste. Portanto $V_{B}$ cresce rapidamente (DINIZ et al., 1999).

Nas ferramentas de cerâmica verifica-se geralmente a quebra de pequenos fragmentos da aresta de corte (lascamento) antes dos desgastes $\mathrm{V}_{\mathrm{B}}$ e KT atingirem valores elevados (DINIZ et al., 1999) (FERRARESI, 1977).

Pode-se verificar a dificuldade de detectar o fim de vida das ferramentas na industria, gerando grandes desperdícios destas. Em operações de desbaste, para evitar a quebra da ferramenta, costuma-se trocar a ferramenta antes do fim de vida desta. Já em operações de acabamento, através de um controle de qualidade on line, por exemplo, calibrador passa-não passa, o operador pode controlar a dimensão da peça e corrigir a posição da ferramenta. Não sendo possível controlar a rugosidade superficial, pois usualmente não possui um rugosímetro a disposição (DINIZ et al., 1999). Uma solução é o monitoramento indireto do desgaste da ferramenta através de sensores de vibração, emissão acústica, parâmetros elétricos da máquina ou força de usinagem e/ou treinamento adequado dos operadores (DINIZ et al., 1999).

Dentre os parâmetros das condições de usinagem que mais influenciam o desgaste das ferramentas, tem-se a velocidade de corte, depois o avanço e por último a profundidade de usinagem (DINIZ et al., 1999).

\subsection{1 - Rugosidade Superficial da peça usinada}

Segundo EZUGWU \& LEONG (1996) e EZUGWU \& TANG (1995), o controle do acabamento superficial é essencial para garantir adequadas condições para vida longa da ferramenta, resistência à fadiga, eficiência máxima e intercambiabilidade funcional do componente usinado no mínimo custo.

$\mathrm{O}$ acabamento final produzido numa operação prática de usinagem é a soma de dois efeitos independentes (EZUGWU \& LEONG, 1996) (EZUGWU \& TANG, 1995):

1) Rugosidade Superficial Ideal: é a melhor superficie que se consegue em função do raio de ponta da ferramenta e do avanço empregado quando se elimina aresta postiça de corte, chatter (pequenas vibrações) e imprecisão do movimento da ferramenta;

2) Rugosidade Superficial Natural ou Rugosidade Atual: é sempre maior que a rugosidade superficial ideal, é causado pelas irregularidades na operação de corte. 
Portanto o raio de ponta da ferramenta e o avanço são variáveis de corte que afetam diretamente a qualidade superficial gerada na usinagem (DINIZ et al., 1999) (EZUWU \& LEONG, 1996). Consegue-se melhorar a rugosidade superficial quando aumenta o raio de ponta da ferramenta e diminui o avanço (DINIZ et al., 1999) (EZUWU \& LEONG, 1996) (ASM, 1989b). O aumento do raio de ponta torna a ponta da ferramenta mais resistente (DINIZ et al., 1999), mas aumenta a vibração da ferramenta devido ao aumento do atrito causado pela maior área de contato ferramenta/peça (DINIZ et al., 1999) (EZUWU \& LEONG, 1996). A diminuição do avanço também tende aumentar o tempo de usinagem e conseqüentemente o custo de produção (EZUWU \& LEONG, 1996).

No APÊNDICE II desenvolve-se uma equação para cálculo teórico da rugosidade superficial média Ra Ideal, exclusivamente em função do raio de ponta $r_{\varepsilon}$ e avanço $f$.

Além da contribuição dos desgastes de flanco, desgastes de entalhe, deformações plásticas da aresta de corte e lascamentos; as superficies usinadas ruins são geralmente associadas a um ou mais dos seguintes fatores (EZUGWU \& TANG, 1995):

- Chatter: causado pela vibração periódica da ferramenta e/ou da peça;

- Feed marks: produzidos pela impressão do raio de ponta da ferramenta em cada revolução da peça;

- Microchip: forma-se na superficie de folga da ferramenta, sendo semelhante à aresta postiça de corte que normalmente forma-se na superficie de saída da ferramenta;

- Sponzipfel: aumenta-se pela formação de uma série de chanfros (ou ranhuras, estrias, entalhes) na aresta de corte de uma ferramenta usada.

Os danos na superficie de peças usinadas durante a usinagem são resultados da interação de processos energéticos (mecânico, eletroquímico, termo-químico, etc) e propriedades dos materiais (tensão, ductilidade, dureza, etc) de uma maneira consistente. Energia mecânica é usada para remoção de material nos processos tradicionais de usinagem por uma ação de cisalhamento entre a ferramenta e a peça, gerando calor e deformação plástica. Este calor gerado normalmente altera a microestrutura da liga e induz tensão residual, sendo a tensão residual induzida também pela deformação plástica sem calor. Calor e deformação, sozinho ou em combinação, pode produzir trincas e mudanças microestruturais durante a usinagem (EZUGWU \& TANG, 1995). 


\section{5 - USINAGEM COM ALTA VELOCIDADE}

Atualmente devido à necessidade de redução de custos e ao aumento da produtividade exigida como conseqüência do desenvolvimento da automação, usinagem com grande taxa de remoção de material é comum (LO CASTO et al., 1993) (ASM, 1989a). No final da década de 80, nos Estados Unidos anualmente são gastos mais de 100 bilhões de dólares para remoção de material metálico, sendo $75 \%$ atribuídos a apenas quatro processos convencionais: torneamento, fresamento, furação e retífica (ASM, 1989a). Fica então evidente que custos podem ser significantemente reduzidos apenas determinando maneiras de aumentar as taxas de remoção de material (ASM, 1989a).

Entre os parâmetros de usinagem: avanço, profundidade de usinagem e velocidade de corte; o aumento da velocidade de corte é a técnica preferida. O aumento dos outros parâmetros aumenta as forças de corte e conseqüentemente requerem o emprego de equipamentos mais rígidos. Mas altas velocidades de corte geram altas temperaturas, então requer materiais com boas propriedades mecânicas, estabilidade química em alta temperatura e boa resistência às tensões induzidas termicamente (LO CASTO et al., 1993). Segundo TOMITA (1999), é necessário que os materiais das ferramentas tenham uma resistência térmica extraordinariamente melhorada, pois o ambiente de corte é muito severo.

Segundo ASM (1989a), pode-se definir teoricamente usinagem com alta velocidade (HSM - High Speed Machining ou HSC - High Speed Cutting) para determinado material como a velocidade acima da qual a localização de cisalhamento desenvolve completamente na zona primária de cisalhamento. Mas não é uma boa definição do ponto de vista prático, para isso uma sugestão é quantificar:

- usinagem de alta velocidade: 600 a $1800 \mathrm{~m} / \mathrm{min}$;

- usinagem de altíssima velocidade: 1800 a $18000 \mathrm{~m} / \mathrm{min} \mathrm{e}$

- usinagem de ultra-alta velocidade de corte: acima de $18000 \mathrm{~m} / \mathrm{min}$.

Mas a definição prática acima não considera o material a ser usinado, uma outra sugestão para usinagem com alta velocidade é a utilização de velocidades de corte cinco a dez vezes maiores que as utilizadas na usinagem convencional em função do material a ser usinado.

Segundo DEONISIO et al. (2000), a utilização de velocidades de corte e avanços acima dos valores convencionais é possível por causa da evolução das ferramentas de corte, dos acionamentos, dos controles e da própria concepção de projeto das máquinas-ferramenta associada ao trabalho de pesquisa e desenvolvimento. A Figura 6 mostra as variáveis do processo relacionadas com a tecnologia de corte HSM (SCHULZ, 1997). 


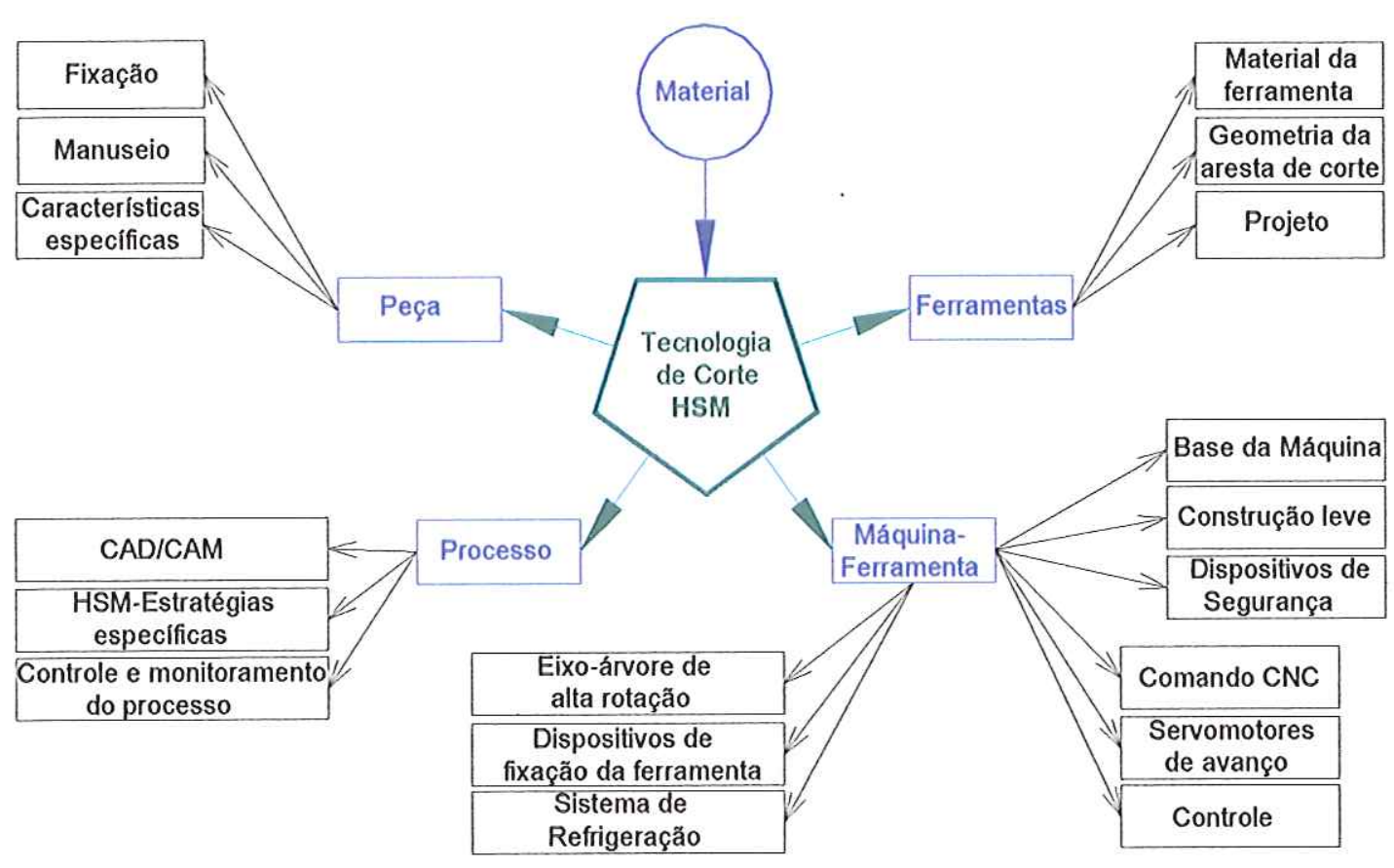

Figura 6 - Variáveis do processo relacionadas com a tecnologia HSM (SCHULZ, 1997)

Geralmente a força de corte tende diminuir com aumento da velocidade de corte (SCHULZ, 1997) (ASM, 1978), mas a partir de certo valor de $v_{c}$ começa aumentar (ASM, 1978). A temperatura de corte aumenta com a velocidade de corte (ASM, 1978).

Com relação ao acabamento superficial, tudo indica que este tende melhorar com aumento da velocidade de corte (SCHULZ, 1997) (ASM, 1989a), mas esse ponto não é conclusivo (ASM, 1989a). Algumas das razões podem ser devido à: ação de polimento devido ao desgaste da ferramenta; menor cavaco e resposta dinâmica da ferramenta de corte (ASM, 1989a).

Segundo ASM (1989a), os dois principais mecanismos de desgaste associados à usinagem com alta velocidade são dissolução e difusão química, sendo o primeiro mais importante para o desgaste. Portanto, a estabilidade química do material da ferramenta é muito importante (VLEUGELS \& VAN DER BIEST, 1998), pois a contribuição relativa do desgaste químico no desgaste total cresce exponencialmente com a velocidade de corte.

A usinagem com alta velocidade também oferece novas possibilidades de flexibilidade e produtividade na tecnologia de manufatura (BUGAUD, 2000).

O metal duro tem desempenho mecânico aceitável até $800^{\circ} \mathrm{C}$, mas em altas temperaturas sua resistência diminui drasticamente. Ao contrário da cerâmica que mantém boa resistência até $1200{ }^{\circ} \mathrm{C}$. Além do mais, em altas velocidades de corte também aumentam o desgaste 
químico. Além disso, dissolução e difusão química são favorecidas em altas temperaturas desenvolvidas na interface entre a peça e a ferramenta (LO CASTO et al., 1993).

As cerâmicas à base de nitreto de silício mantêm sua dureza em altas temperaturas. Portanto são recomendadas na usinagem de alta velocidade, onde a reação química entre o material da ferramenta e o cavaco muito quente é pequena (EKSTRÖM, 1989).

Segundo LO CASTO et al. (1993), as cerâmicas à base de nitreto de silício são boas para usinagem de ferro fundido, superligas a base de níquel e ligas de alumínio-silício em velocidades moderadas, no entanto, em altas velocidades de corte de ligas de ferro, o desempenho não é satisfatório. Mas para EKSTRÖM (1989), em altas velocidades de corte estas cerâmicas têm ótimo desempenho com ferro fundido e ligas aeroespaciais, não acontecendo o mesmo com o a̧̧o.

\section{6 - USINABILIDADE DE FERRO FUNDIDO}

\subsection{1 - Usinabilidade}

Usinabilidade, segundo DINIZ et al. (1999), pode ser definida como uma grandeza tecnológica numérica comparativa com um padrão e expressa um conjunto de propriedades de usinagem de um material, isto é, o grau de dificuldade de usinar um determinado material.

As propriedades de usinagem de um material expressam seu efeito sobre grandezas mensuráveis inerentes ao processo de usinagem, tais como a vida da ferramenta, o acabamento superficial da peça, os esforços de corte, a temperatura de corte, a produtividade e as características do cavaco. Portanto, a usinabilidade relaciona-se diretamente com as propriedades de usinagem, pode ser boa para uma propriedade e não para outra.

A usinabilidade depende das condições: do material: estado metalúrgico da peça, dureza, propriedades mecânicas do material, composição química, operações anteriores efetuadas sobre o material (sejam a frio ou a quente) e eventual encruamento; de usinagem: características da ferramenta, condições de refrigeração, rigidez do sistema máquinadispositivo de fixação-peça-ferramenta e tipos de trabalho executados pela ferramenta (operação empregada, corte contínuo ou intermitente, condições de entrada e saída da ferramenta).

Segundo KOMANDURI \& SAMANTA (1989), dependendo das condições de usinagem algumas propriedades das ferramentas são mais importantes (Figura 7). Resistência mecânica e tenacidade são importantes em cortes interrompidos, altos valores de avanço e alta profundidade de corte, enquanto dureza a quente e resistência à abrasão são mais importantes 
com o aumento da velocidade de corte. Resistência ao choque térmico é desejada quando altas tensões mecânicas, altas velocidades de corte, ou uso de fluidos de corte estão envolvidos. A estabilidade química (quimicamente inerte) é também uma propriedade importante em altas velocidades de corte.

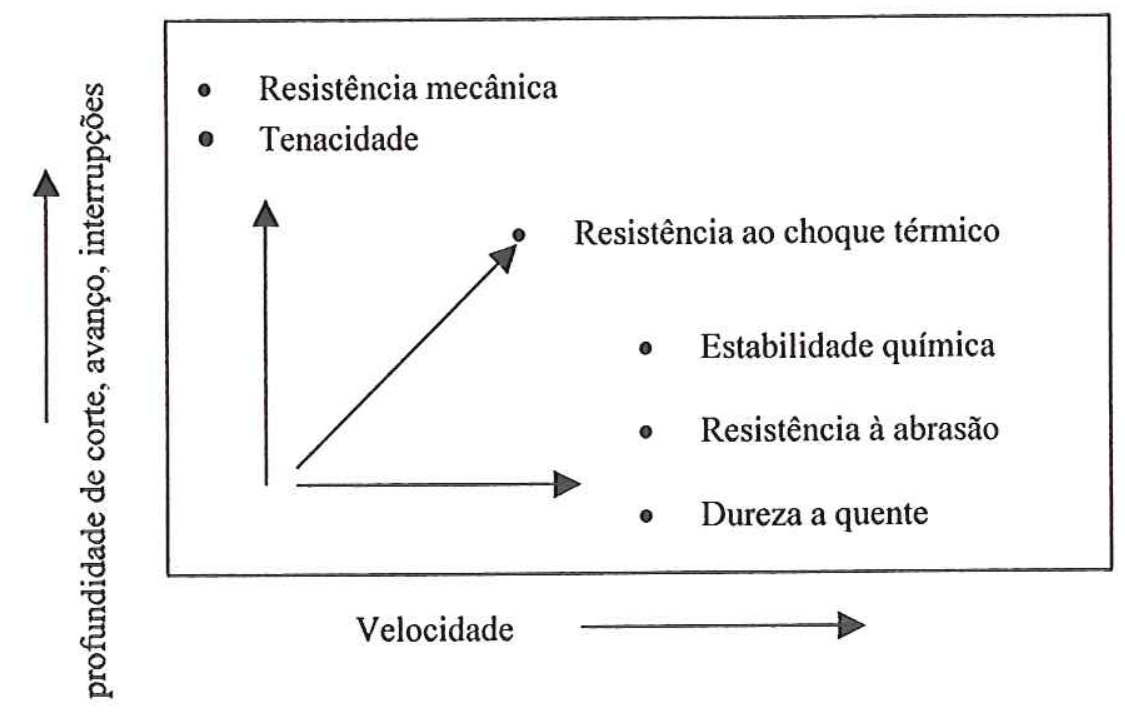

Figura 7 - Principais propriedades das ferramentas versus condições de usinagem (KOMANDURI \& SAMANTA, 1989)

\subsection{2 - Usinabilidade de Ferro Fundido Cinzento}

De acordo com DeBENEDICTIS (1997), geralmente as principais propriedades para usinar ferro fundido são a alta dureza a quente e estabilidade química.

A usinabilidade da maioria dos ferros fundido cinzento é superior que a maioria dos outros ferros fundidos de mesma dureza e na prática de todos os aços (ASM, 1989b).

Segundo YAMANE et al. (1990), a usinabilidade do ferro fundido na usinagem com alta velocidade não é muito boa.

Segundo HEATH (1989), a microestrutura do ferro fundido cinzento é o principal indicador de sua usinabilidade. $\mathrm{O}$ ferro fundido apresenta uma estrutura em que a matriz é ferrítica ou ferrítico-perlítica (EZUGWU et al., 1995) (HEATH, 1989). Uma redução no teor de ferrita livre ou um refinamento do espaçamento da perlita lamelar reduzem a usinabilidade (VOIGT, 1999) (DeBENEDICTIS, 1997) (EZUGWU et al., 1995) (HEATH, 1989). Porém, segundo EZUGWU et al. (1995), pode ser endurecida no estado sólido com algumas inclusões no ferro fundido cinzento, particularmente silício, conduzindo no aumento da dureza de aproximadamente $100 \mathrm{HB}$ para $200 \mathrm{HB}$ quando o teor de silício aumenta de $1 \%$ para $4 \%$. Manganês tem efeito similar, mas menor intensidade. 
A perlita aumenta a resistência do ferro fundido e diminui sua usinabilidade (EZUGWU et al., 1995). Conforme exposto no item 2.1.1, a dureza da perlita depende da velocidade de resfriamento, sendo que o aumento da dureza reduz a usinabilidade do ferro fundido cinzento (EZUGWU et al., 1995).

Cada tipo de material tem fatores diferentes que mais influem na usinabilidade, por exemplo, quando se trata de ferro endurecido o principal indicador é a dureza (HEATH, 1989).

Além da influência da própria matriz ou a porcentagem relativa de ferrita e perlita presentes, os veios de grafita (quantidade, distribuição e tamanho) também são fatores importantes na usinabilidade do material. Segundo BOEHS et al. (2000); EZUGWU et al. (1995); ASM (1989b) e ASM (1978), os veios de grafita introduzem descontinuidades na matriz do metal, agindo como um quebra cavaco. A grafita é um lubrificante natural para a ferramenta de corte (BOEHS et al., 2000) (ASM, 1989b) (ASM, 1978). VOIGT (1999) observa em videoteipes (aumento de 50x) que a grafita forma na interface ferramenta/peça uma fina película sólida que reduz a força e o atrito.

Existem dois tipos de elementos que influenciam a usinabilidade: os prejudiciais formadores de carbonetos (partículas muito duras e abrasivas), tais como cromo, cobalto, manganês, molibdênio e vanádio; e os grafitizantes (silício, níquel, alumínio e cobre) que auxiliam a usinabilidade (DINIZ et al., 1999) (DeBENEDICTIS, 1997). Sendo que o enxofre e o manganês também melhoram a usinabilidade (DINIZ et al., 1999).

Freqüentemente, problemas na usinagem de ferro fundido cinzento podem ser devido a um ou mais dos seguintes fatores de fundição (ASM, 1989b) (ASM, 1978):

- Presença de resfriadores nos cantos e em seções finas;

- Presença de areia aderida na superfície do fundido;

- Defeitos tais como, dilatações, bolhas, bossa em peça fundida; normalmente resultado de moldes moles, brandos, macios ou lisos;

- Desencontro das faces de contato (em caixas de moldagem) e

- Contrações.

EZUGWU et al. (1995) acrescentam que algumas inclusões podem causar problemas na usinagem: fosfeto de ferro eutético (freqüentemente adicionado para aumentar a fundibilidade), carbonetos livres, e óxido-silicatos e nitretos produzidos de fragmentos de materiais ou dos refratários.

Pelo fato do ferro fundido ser frágil e da presença de grafita em sua estrutura, seu cavaco é "pequeno", contendo partículas duras de cementita. Portanto é razoável assumir que gera 
desgaste de cratera, mas no caso do inserto de cerâmica, normalmente chanfrado, os cavacos atritam com a superfície chanfrada e de folga, mas os grãos abrasivos quebram entre a peça e a superfície de folga, gerando $V_{B}$ (KATSUMURA et al., 1993).

Normalmente a usinagem de ferro fundido cinzento não utiliza fluido de corte líquido, este poderia carregar os minúsculos cavacos formados consigo, penetrando nas partes de atrito da máquina-ferramenta, danificando-a. Devido a esta usinagem a seco, a peça aquece bastante (dilata muito), e não permite obtenção de tolerâncias apertadas. Uma opção para operações de usinagem de acabamento é a utilização de ar comprimido como fluido refrigerante (DINIZ et al., 1999). Mas DeBENEDICTIS (1997) recomenda fluido de corte abundante e alta velocidade para evitar aresta postiça de corte e diminuir desgaste de flanco $V_{B}$. A geometria da ferramenta também é importante, recomenda-se ferramenta plana com cobertura de $\mathrm{Al}_{2} \mathrm{O}_{3}$ para prevenir desgaste abrasivo.

Na Figura 8 KOMANDURI \& SAMANTA (1989) exemplificam aplicações de usinagem de ferro fundido (100 a $300 \mathrm{HB}$ ) com profundidade de corte $\mathrm{a}_{\mathrm{p}}=1 \mathrm{~mm}$ com diferentes materiais de ferramenta em função da velocidade de corte $v_{c}$ e avanço $f$.

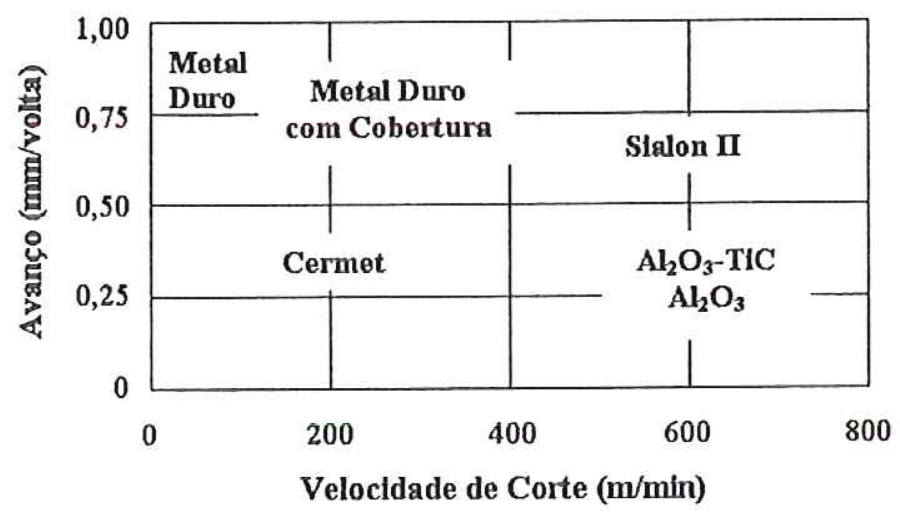

Figura 8 - Aplicações de usinagem de ferro fundido (100 a $300 \mathrm{HB})$. Sialon II é produto da Kennametal Inc. (KOMANDURI \& SAMANTA, 1989)

Segundo DeBENEDICTIS (1997), o raio de ponta da ferramenta é um fator importante na resistência da ferramenta, desgaste da ferramenta e acabamento da peça. Recomenda raio de ponta $1,2 \mathrm{~mm}$ ou maior para torneamento de ferro fundido. Geralmente em operação de acabamento, o avanço não deve ser maior que $1 / 3$ do raio de ponta $r_{\varepsilon}$ para obter boa qualidade e precisão superficial. $\mathrm{O}$ desgaste $\mathrm{V}_{\mathrm{B}}$ é causado principalmente pela abrasão por carbonetos, inclusões de areia e superfícies endurecidas.

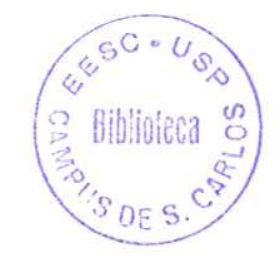




\subsubsection{1 - Metal Duro}

A Figura 9 mostra o efeito da estrutura da matriz do ferro fundido cinzento na velocidade de corte do torneamento deste com ferramentas de metal duro.

\begin{tabular}{|c|c|c|c|c|c|}
\hline \multicolumn{7}{|c|}{ VIDA DA FERRAMENTA } & - \\
\hline & \multicolumn{5}{|c|}{ Porcentagem Relativa } \\
\hline \% Ferrita & 100 & 50 & 0 & 0 & 0 \\
\hline$\%$ Perlita Grosseira & 0 & 50 & 100 & - & - \\
\hline \% Perlita Fina & - & - & - & 100 & 95 \\
\hline \% Cementita & - & - & - & - & 5 \\
\hline Dureza Brinell & 120 & 150 & 195 & 218 & 240 \\
\hline $\mathrm{v}_{\mathrm{c}}$ recomendado & $4,00 \mathrm{v}_{\mathrm{c}}$ & $2,75 \mathrm{v}_{\mathrm{c}}$ & $1,61 \mathrm{v}_{\mathrm{c}}$ & $1,34 \mathrm{v}_{\mathrm{c}}$ & $\mathrm{v}_{\mathrm{c}}$ \\
\hline
\end{tabular}

Torneamento de ferro fundido cinzento com inserto de metal duro

Figura 9 - Efeitos da estrutura em $\mathrm{v}_{\mathrm{c}}$ de torneamento de ferro fundido cinzento (CHIAVERINI, 1984)

\subsubsection{2 - Metal Duro com Cobertura}

Segundo GRAHAM (1994), as coberturas mais bem sucedidas para aplicações gerais em usinagem (usualmente em materiais ferrosos) são o $\mathrm{TiC}$, $\mathrm{TiN}$ e $\mathrm{Al}_{2} \mathrm{O}_{3}$. Atualmente quase todos os metais duros usados em usinagem de ferrosos são com coberturas.

\subsubsection{3 - Cermet}

Segundo ENDLER et al. (1994), a relativa falta de importância em aplicações industriais de cermet sem cobertura na usinagem de ferro fundido é causada pelo progressivo desgaste de flanco, desgaste de cratera e em parte pela formação de aresta postiça de corte.

Para SIGL et al. (1994), cermets de $\mathrm{TiB}_{2}$ austeníticos trabalham bem com ferro fundido e mostram um potencial na usinagem de aços.

Segundo ENDLER et al. (1994), o cermet com cobertura de TiN $\mathrm{x}_{\mathrm{x}}$ pelo processo PECVD causa um aumento substancial na performance de usinagem em torneamento contínuo e descontínuo de aço e ferro fundido. Em torneamento de ferro fundido aumenta a resistência ao desgaste e a vida da ferramenta com o aumento da espessura da camada. 


\subsubsection{4 - Material Cerâmico}

A área de maior aplicação das cerâmicas é a usinagem do ferro fundido em peças da indústria automobilística, onde todas as categorias de cerâmicas podem ser usadas, dependendo de cada aplicação (DINIZ et al., 1999) (ASM, 1989b). Por exemplo, na usinagem de revestimento de embreagem e freio automotivo de ferro fundido utiliza-se cerâmica a base de alumina com velocidade de corte de $600 \mathrm{~m} / \mathrm{min}$ para obter bom acabamento superficial, objetivando eliminar operação subseqüente de retificação (TRENT, 1991).

Ferramentas de cerâmica são ideais para usinagem de ferro fundido. Devido à alta dureza a quente, alta resistência ao desgaste, alta resistência à deformação plástica e estabilidade química; qualidades que permitem altas velocidades de corte, avanço e profundidade de usinagem.

O desgaste abrasivo nas ferramentas de cerâmica é causado principalmente por carbonetos duros ou inclusões de óxidos ou segundas fases na peça. As próprias partículas fraturadas da ferramenta carregadas pelos cavacos causam desgastes abrasivos. Portanto a dureza do material da ferramenta e da peça, inclusões duras/segundas fases, microestrutura do material da ferramenta e da peça e comportamento da micro-fratura do material da ferramenta determinam o mecanismo de desgaste abrasivo das ferramentas de cerâmica (MEHROTRA, 1998).

Segundo TRENT (1991), as cerâmicas de alumina podem usinar aços com velocidades de corte superiores àquelas usadas para ferramentas de metal duro convencional e ligas a base de TiC.

Cerâmicas a base de alumina com ângulo de saída negativo podem usinar ferro fundido $\mathrm{e}$ muitos aços com velocidade de corte de 600 a $750 \mathrm{~m} / \mathrm{min}$ e avanço de $0,25 \mathrm{~mm} /$ volta por longos períodos sem desgaste excessivo. Ferramentas usadas em alta velocidade mostram desgaste de flanco e um tipo de craterização que começa próximo à aresta de corte. $\mathrm{O}$ desgaste nestas condições, onde a alta temperatura na interface é causada pela deformação superficial plástica e fluxo de uma camada muita fina da ferramenta, em lugar da difusão para o material da peça (TRENT, 1991).

As cerâmicas puras são recomendadas na usinagem de fundidos de boa qualidade (sem impurezas ou poros) e pré-usinados (sem casca de fundição e sem excentricidade), não exigindo grande tenacidade e resistência ao choque térmico, pois nestes casos a possibilidade 
de choques (causados pelas impurezas ou pelos poros) ou variação térmica (causada pela variação da profundidade de usinagem de peças excêntricas) é menor (DINIZ et al., 1999).

No torneamento contínuo a seco de ferro fundido cinzento, dentre as classes das cerâmicas, segundo D'ERRICO et al. (1997), as cerâmicas puras têm o melhor desempenho; sendo que para BHATTACHARYYA et al. (1989), as cerâmicas mistas têm melhor desempenho que cerâmicas puras e a base de nitreto de silício.

As cerâmicas mistas (principalmente os com TiN) e aquelas a base de $\mathrm{Si}_{3} \mathrm{~N}_{4}$ são melhores que as cerâmicas brancas quando existe a variação térmica, exigindo material mais resistente a trinca térmica, sendo os a base de $\mathrm{Si}_{3} \mathrm{~N}_{4}$ a primeira escolha (DINIZ et al., 1999).

KATSUMURA et al. (1989) estudam o desempenho de corte de ferramentas de cerâmica $\mathrm{Al}_{2} \mathrm{O}_{3}$-TiC (25\% - hot-pressing) no torneamento de ferro fundido cinzento em função do tamanho do grão de $\mathrm{Al}_{2} \mathrm{O}_{3}$ e verificam que grãos finos têm maiores desgastes de flanco.

Mas segundo KATSUMURA et al. (1993), as cerâmicas mistas $\left(\mathrm{Al}_{2} \mathrm{O}_{3}\right.$-TiC, hotpressing) contendo maiores teores e tamanho de grãos mais finos de $\mathrm{TiC}$ mostram maiores desgastes de flanco $\left(V_{B}\right)$ no torneamento de ferro fundido cinzento, sendo que o tamanho de grão de $\mathrm{Al}_{2} \mathrm{O}_{3}$ não afeta $\mathrm{V}_{\mathrm{B}}$, portanto, observa-se que o aumento de dureza diminui a resistência ao desgaste. Já no caso de torneamento de ferro fundido nodular, $V_{B}$ diminui com o aumento do teor de TiC, mas o tamanho de grão não afeta $V_{B}$. TAKAHASHI (1998) encontra a mesma relação no torneamento de ferro fundido cinzento com cerâmica branca $\mathrm{Al}_{2} \mathrm{O}_{3}$-TiC.

EZUGWU \& TANG (1995) analisam o desgaste de ferramentas de cerâmica mista $\mathrm{Al}_{2} \mathrm{O}_{3}$-TiC no torneamento de ferro fundido G-17 com $\mathrm{v}_{\mathrm{c}}>500 \mathrm{~m} / \mathrm{min}$. Concluem a geração de alta temperatura e tensões (compressão e tração) durante usinagem, deste modo aumenta o desgaste de flanco. Um aumento do desgaste de flanco conduz a um aumento do comprimento de contato ferramenta-cavaco, que aumenta a temperatura e tensão/pressão de compressão. Uma zona de intenso cisalhamento desenvolve-se na superfície de folga da ferramenta. Este desenvolvimento conduz para remoção de partículas da ponta da ferramenta. Estas partículas removidas tendem soldar na superfície recém usinada, e resultam em ruim acabamento superficial. Contrariando o pensamento de que ferramentas de cerâmica não se soldam ou aderem facilmente em materiais ferrosos como fazem outros materiais de ferramenta, como aço rápido e metal duro, já que é não-metálico. Estudos posteriores em ferramentas de cerâmica mostram que cerâmica de alumina também pode ter tendência para soldagem entre a ferramenta e o material da peça.

Segundo EZUGWU \& TANG (1995), no torneamento a seco de ferro fundido G17 com ferramentas de inserto redondo e romboidal de cerâmica mista $\left(\mathrm{Al}_{2} \mathrm{O}_{3}\right.$-TiC) geralmente 
produz superfícies de acabamento melhores que cerâmicas de óxido puro $\left(\mathrm{Al}_{2} \mathrm{O}_{3}-\mathrm{ZrO}_{2}\right)$ por causa de sua maior dureza a quente, tenacidade à fratura e resistência ao desgaste.

EZUGWU \& TANG (1995) também observam que para a cerâmica de óxido puro $\left(\mathrm{Al}_{2} \mathrm{O}_{3}-\mathrm{ZrO}_{2}\right)$ com velocidade de corte de $300 \mathrm{~m} / \mathrm{min}$ :

- Os insertos redondos conseguem obter melhores superficies de acabamento e menores danos que insertos romboidais, devido ao seu grande raio de ponta que minimiza o efeito dente de serra na superficie usinada, não observa o efeito da vibração, que segundo DINIZ et al. (1999), normalmente com o aumento do raio de ponta aumenta a vibração da ferramenta devido ao aumento do atrito causado pela maior área de contato ferramenta-peça, prejudicando o acabamento. Atualmente devido à rigidez do sistema máquina-ferrameta-dispositivo de fixação peça em alguns casos o efeito da vibração não se manifesta.

- Notam-se altos valores de rugosidade (especialmente com insertos romboidais), deve-se à baixa dureza a quente e à baixa tenacidade à fratura desta classe de cerâmica. Isto fornece uma fraca resistência na aresta de corte durante a usinagem, resulta em perda (lascamento - chipping) de partículas da ferramenta. A suscetibilidade desta cerâmica ao chipping tende alterar a geometria da aresta de corte, assim também aumenta a área de contato ferramenta-peça. Isto reduz o ângulo de folga e ao mesmo tempo aumenta o atrito da superficie de folga da ferramenta com a superficie recém formada.

YAMANE et al. (1990) verificam que no torneamento de ferro fundido cinzento FC25 com ferramenta de nitreto de silício $\left(\mathrm{f}=0,21 \mathrm{~mm} /\right.$ volta $\left.\mathrm{e} \mathrm{a}_{\mathrm{p}}=1 \mathrm{~mm}\right)$ com o aumento da velocidade de corte diminui o desgaste da ferramenta, especialmente desgaste de cratera, devido à formação de uma camada protetora que age como uma barreira para a difusão, que supostamente pode ser de dois tipos: inclusões de óxido do material da peça depositado na superficie da ferramenta ou ainda a própria oxidação da superficie da ferramenta. Embora esta última afirmação feita no trabalho seja pouco provável devido à estabilidade química dos materiais cerâmicos.

DINIZ et al. (1999) e MEHROTRA (1998) concluem que as cerâmicas a base de nitreto de silício são mais adequadas para torneamento em desbaste e operações com corte interrompido ou variação térmica, e as cerâmicas a base de óxido são mais adequadas para a usinagem em acabamento e semi-acabamento de fundidos de boa qualidade sob condições de usinagem estáveis.

Quando usina ferro fundido G-17 com ferramentas de cerâmica, ocorre transformação de fase ou mudanças metalúrgicas associadas com a região sub-superficial, conseqüência das 
altas temperaturas geradas e aderência entre a região da ponta da ferramenta e a peça durante a usinagem (EZUGWU \& LEONG, 1996).

Com relação à estabilidade química, a alumina $\left(\mathrm{Al}_{2} \mathrm{O}_{3}\right)$ é a cerâmica mais quimicamente inerte, enquanto o nitreto de silício $\left(\mathrm{Si}_{3} \mathrm{~N}_{4}\right)$ e o carboneto de silício ( $\mathrm{SiC}$ ) são mais reativos com o cobalto e o ferro. A reatividade do $\mathrm{SiC}$ com materiais ferrosos parece ser a razão pela qual a alumina reforçada com "wiskers" é limitada para aplicações com peças de super ligas à base de níquel (KOMANDURI \& SAMANTA, 1989).

SILVA et al. (1998) observam que as ferramentas de nitreto de silício apresentam a mais alta resistência ao desgaste pela dissolução quando usina ferro fundido cinzento, ao contrário da usinagem de aços, onde o desgaste químico pela afinidade por dissolução no metal é o limitador de usinagens de alta velocidade.

Segundo D'ERRICO et al. (1997), as cerâmicas à base de nitreto de silício têm o melhor desempenho no torneamento de ferro fundido cinzento com fluido de corte, já as cerâmicas à base de alumina têm baixo desempenho com fluido de corte, provavelmente devido à limitada capacidade ao choque térmico, conseqüência dos altos coeficientes de expansão térmica.

Em um comparativo, no torneamento de ferro fundido cinzcints, as cerâmicas a base de nitreto de silício podem usinar com velocidade de corte $200 \%$ maior que ferramentas de metal duro com cobertura de cerâmica (MEHROTRA, 1998).

GNESIN \& YAROSHENKO (1994) estudam o comportamento de duas classes de cerâmica à base de nitreto de silício:

- As cerâmicas à base de Sialon-TiN podem tornear tanto ferro fundido como aço, tendo desgaste $V_{B}$ próximos. Mas em contato com aço, a geometria de corte da ferramenta muda facilmente, forma-se ao mesmo tempo desgaste de flanco e desgaste de cratera na superfície de saída. Já no torneamento de ferro fundido forma-se rapidamente uma aresta de corte arredondada o qual apesar disso, prossegue-se trabalhando;

- As cerâmicas à base de $\mathrm{Si}_{3} \mathrm{~N}_{4}-\mathrm{Y}_{2} \mathrm{O}_{3}-\mathrm{Al}_{2} \mathrm{O}_{3}$ tem desgaste catastrófico no torneamento de aço e ferro fundido devido à interação cerâmica-metal.

OGASAWARA et al. (1999) analisam os depósitos nas superficies de folga e saída de ferramentas de nitreto de silício no torneamento de ferro fundido cinzento. O desgaste na superficie de folga e de saída diminui com o aumento da velocidade de corte na faixa de 100 a $300 \mathrm{~m} / \mathrm{min}$ no torneamento de ferro fundido cinzento. Análises na superficie de saída e de folga com $v_{c} 300 \mathrm{~m} / \mathrm{min}$ detectam depósitos de Mn, S, Al e O. Na superfície de saída os principais depósitos são $\mathrm{Al}_{2} \mathrm{O}_{3}$ e óxidos de silício $\left(\mathrm{SiO}_{2}\right.$ e $\left.\mathrm{SiO}_{\mathrm{x}}\right)$ em camadas de 1 a $2 \mu \mathrm{m}$ de 
espessura, sendo que estas camadas depositadas previnem contato direto entre a ferramenta e a peça. Ao contrario com $\mathrm{v}_{\mathrm{c}} 100 \mathrm{~m} / \mathrm{min}$, pequena quantidade de $\mathrm{Al}$ e $\mathrm{O}$ é encontrada.

\subsubsection{5 - Nitreto Cúbico de Boro Policristalino (PCBN)}

Infelizmente, as especificações para componentes críticos da industria automotiva, tais como, freio de disco, normalmente requerem ferro fundido cinzento com um teor mínimo de ferrita e um espaçamento relativamente fino de perlita. Portanto a usinabilidade pode ser um problema, e altos custos de usinagem e perdas na produção devido às freqüentes trocas de ferramenta podem ser significantes. Neste caso, ferramentas de PCBN trabalham bem com velocidade de corte $\mathrm{v}_{\mathrm{c}}>500 \mathrm{~m} / \mathrm{min}(\mathrm{HEATH}, 1989)$.

A ferrita freqüentemente associada com veios de grafita é uma fase altamente reativa e produz desgaste rápido nas ferramentas de PCBN (HEATH, 1989).

A escolha da velocidade de corte $v_{c}$ na usinagem de ferro fundido cinzento com ferramenta de PCBN é muito importante. Na Figura 10, por exemplo, com PCBN de desbaste (Amborite - PCBN sólido) verifica-se que a vida da ferramenta aumenta com o aumento da velocidade de corte, ao contrário da cerâmica mista e Sialon (HEATH, 1989).

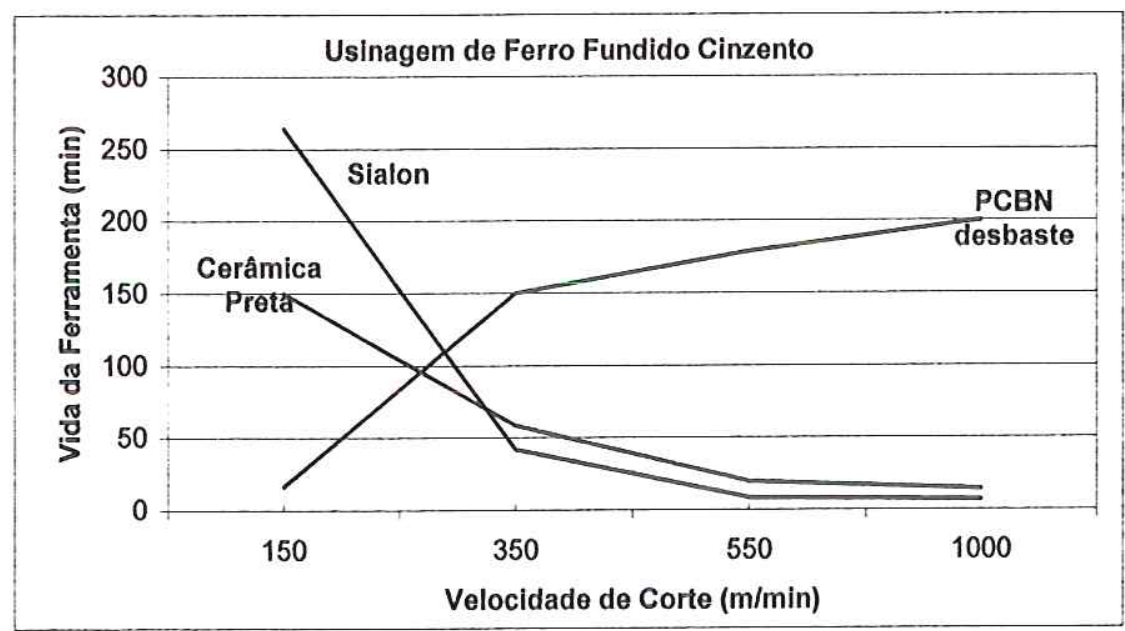

Figura 10 - Efeito de $\mathrm{v}_{\mathrm{c}}$ na vida da ferramenta para $\mathrm{V}_{\mathrm{B}}=0,2 \mathrm{~mm}$ (ferro fundido cinzento). Condições: $\mathrm{f}=0,1 \mathrm{~mm} /$ volta e $\mathrm{a}_{\mathrm{p}}=1,0 \mathrm{~mm}$ (HEATH, 1989)

Neste caso para $v_{c}>1000 \mathrm{~m} / \mathrm{min}$, HEATH (1989) diz que o PCBN tem comportamento semelhante às ferramentas de materiais convencionais, isto é, aumentando $\mathrm{v}_{\mathrm{c}}$, a vida da ferramenta diminui. 
Exemplo de aplicação de PCBN em comparação com cerâmica (DINIZ et al., 1999):

- Torneamento de disco de freio:

- material: ferro fundido cinzento (200 HB)

- desbaste: $v_{c}=300$ a $480 \mathrm{~m} / \mathrm{min} ; \mathrm{f}=1,27 \mathrm{~mm} /$ volta; $a_{p}=1,4 \mathrm{~mm}$

- refrigeração: a seco

- resultados: PCBN (3000 peças por aresta) e $\mathrm{Si}_{3} \mathrm{Ni}_{4}$ (100 a 200 peças por aresta de corte).

\section{7 - FLUIDOS DE CORTE}

O norte-americano F. W. Taylor é o primeiro pesquisador a estudar a influência de fluidos de corte durante os processos de usinagem em 1894. No seu experimento joga-se grande quantidade de água na região formada pela peça-ferramenta-cavaco, consegue-se aumentar em $33 \%$ a velocidade de corte, sem prejuízo para a vida útil da ferramenta (RUFFINO, 1977). Mas a água tem duas desvantagens: favorece oxidação e tem baixo poder lubrificante (DINIZ et al., 1999).

Na procura de maior produtividade, a utilização de novos materiais para as ferramentas de corte permite atingir velocidades de corte cada vez maiores. Mas quanto maior a velocidade de corte, maior o atrito peça-ferramenta-cavaco, libera-se mais calor e prejudica a qualidade do trabalho (diminui a vida útil da ferramenta).

Como visto no item 2.3.1- Temperatura de Corte, durante o corte desenvolve-se uma grande quantidade de calor. O fluido de corte tem a função de reduzir e/ou extrair o calor da ferramenta e da peça, com a finalidade de minimizar o desgaste da ferramenta, a dilatação térmica da peça e o dano térmico à estrutura superficial da peça, em conseqüência os esforços e a potência também minimizam (DINIZ et al., 1999).

Segundo RUFFINO (1977), a função do fluido de corte é introduzir uma melhoria funcional e econômica no processo de usinagem dos metais.

As funções desejadas de um fluido de corte, em relação à melhoria funcional, são (RUFFINO, 1977):

- lubrificar e/ou refrigerar o corte;

- prevenir contra a soldagem cavaco-ferramenta;

- retirar o cavaco da região de corte;

- reduzir a dilatação (distorção) térmica da peça;

- melhorar acabamento superficial da peça usinada e 
- evitar danos à estrutura superficial e o crescimento exagerado de tensões residuais na superficie da peça usinada (principalmente em processos de retificação).

As funções desejadas de um fluido de corte, em relação à melhoria econômica, são (RUFFINO, 1977):

- reduzir o consumo de energia de corte;

- reduzir o custo da ferramenta na operação e

- impedir a corrosão da peça em usinagem.

As características principais que um fluido de corte deve ter são (DINIZ et al., 1999):

- refrigerante: possuir baixa viscosidade; capacidade de "molhar" bem o metal para estabelecer um bom contato térmico e alto calor específico e alta condutividade térmica;

- lubrificante: resistir a pressões e temperaturas elevadas sem vaporizar; boas propriedades anti-fricção e anti-soldantes e viscosidade adequada (baixa para fácil circulação e alta para boa aderência);

- ausência de odores desagradáveis;

- não corroer (proteção contra corrosão);

- isenção da tendência a originar precipitados sólidos que depositam nas guias da máquina e/ou entopem os tubos de circulação do fluido de corte;

- não causar dano à pele humana e nenhum outro risco à saúde.

Em altas velocidades de usinagem, a refrigeração é a função mais importante dos fluidos de corte. Em moderadas velocidades de usinagem, a lubrificação e a refrigeração são importantes, mas em baixas velocidades, a lubrificação torna-se a função dominante do fluido de corte (NACHTMAN, 1989).

No caso de alguns materiais de ferramentas, por exemplo, as cerâmicas a base de óxido de alumínio suportam altas temperaturas, mas não suportam variação de temperatura, pois trincam ou quebram. Portanto evita-se a utilização de fluido de corte, a não ser que consiga um fluxo com vazão e direção constante para manter a temperatura de corte constante. Caso não utilize fluido de corte, deve-se tomar cuidados para que a peça não se danifique com o calor excessivo (DINIZ et al., 1999).

A função da lubrificação é reduzir o coeficiente de atrito entre o cavaco e ferramenta e ferramenta e peça, através do fenômeno de capilaridade (ajudado pela vibração entre ferramenta, peça e cavaco), facilita o fluxo de cavaco e reduz a força, a potência de corte e a temperatura (DINIZ et al., 1999). 
Segundo RUFFINO (1977), os diversos fluidos de corte podem ser classificados em três tipos: sólidos, líquidos e gasosos. No ANEXO B, encontram-se as principais características desses fluidos de corte.

\subsection{1 - Efeitos biológicos e outras desvantagens dos fluidos de corte líquidos}

Um correto procedimento de usinagem é o contato reduzido com os fluidos de corte, pois estes têm alguns componentes tóxicos, tais como: bactericidas, aditivos EP, antioxidantes, inibidores de corrosão e corantes (NACHTMAN, 1989). Portanto, o fluido de corte não pode entrar em contato com o ser humano, e as formas possíveis de sua assimilação pelo homem são: pelo estômago - sistema digestivo (assimilação oral); pelos órgãos respiratórios; e pela pele e membranas mucosas (HEISEL et al., 1998).

Os efeitos nos seres humanos têm sido testados em animais, mas existe uma grande incerteza entre a relação destes resultados e a saúde humana (NACHTMAN, 1989).

Os fluidos de corte provocam doenças de pele (BURGES, 1997) (SAHM \& SCHNEIDER, 1996) (NACHTMAN, 1989) (RUFFINO, 1977); irritações oculares (SAHM \& SCHNEIDER, 1996); doenças respiratórias geradas pela inspiração dos seus vapores (SAHM \& SCHNEIDER, 1996), tais como bronquite, asma e diminuição nas funções pulmonares (BURGES, 1997); câncer na laringe e no aparelho digestivo (BURGES, 1997); além de outros distúrbios. A associação entre o contato da pele com os fluidos de corte à base de óleo mineral e o carcinoma de células escamosas é descrita no século passado no Reino Unido (BURGES, 1997).

Os efeitos mais comuns dos fluidos de corte são doenças de pele, devido ao contato prolongado (BURGES, 1997) (NACHTMAN, 1989):

- dermatite de contato (inflamação da derme): primeiramente causado pela remoção de óleos naturais da pele devido à presença de água, solventes, emulsificadores e/ou sabões nos fluidos de corte. Um fluido de corte com pH acima de 9,0 pode também acelerar a ocorrência de dermatite (NACHTMAN, 1989). BURGES (1997) classifica três tipos principais de fluido de corte em ordem decrescente de potencial: sintéticos, emulsões e óleo mineral;

- foliculite (infecção da pele que atinge os folículos pilosos, caracteriza-se por inflamação e pus em torno do pêlo) e acne (enfermidade cutânea que se caracteriza pela inflamação dos folículos pilosos, com retenção da secreção das glândulas sebáceas): exposição prolongada com fluidos de corte à base de óleo pode obstruir os poros e folículos 
capilares da pele formando pontos pretos (NACHTMAN, 1989) (RUFFINO, 1977). O óleo natural segregado pela pele e a bactéria normalmente nela existente se acumulam sob esses pontos pretos, desenvolvem irritação, que pode se transformar em erupções postulares ou espinhas (RUFFINO, 1977). Apesar do cuidado para manter a pele limpa, bactérias podem contribuir para formação de foliculite e furúnculos (NACHTMAN, 198);

- mudanças na cor da pele e engrossamento: podem ser também associados com a formação de foliculite (NACHTMAN, 1989);

- rachaduras na pele: todos os óleos à base de petróleo têm a propriedade de retirar a gordura natural da pele, ressecando-a, com a tendência para rachar. Estas rupturas da pele podem ser o começo de uma infeç̧ão. A presença de aditivos no óleo, tais como enxofre, cloro, gorduras e sabões vegetais ou animais pode irritar mais agudamente a pele do operário (RUFFINO, 1977);

- tumor benigno e maligno: óleos à base de petróleo refinados, a partir de óleo cru, contêm concentração variada de hidrocarbonetos aromáticos policíclicos. Estes compostos policíclicos parecem estar correlacionados com a formação de crescimento exagerado de pele escamosa e tumores benignos e malignos. Apropriado hidro-teste ou purificação dos solventes removem a maioria dos compostos indesejados (NACHTMAN, 1989). BURGES (1997) classifica três tipos principais de fluido de corte em ordem decrescente de potencial: óleo mineral, emulsões e sintéticos.

Os possíveis micróbios existentes nos fluidos de corte são freqüentemente sub classificados em bactérias e fungos (bolores ou mofos e germes) e podem crescer em fluidos de corte à base de água em taxas extremamente altas, depende das condições e do tipo de micróbio. Em geral, a população dobra a cada 15 ou 30 minutos. Mesmo em fluidos à base de óleo, contaminação em água pode causar indesejável infestação microbial (NACHTMAN, 1989).

Bactérias são comumente associadas com emulsões, e bolores são comumente associados com soluções aquosas (sintéticas). Em geral, existe um antagonismo natural entre bactéria e fungos. No controle de crescimento de bactérias, os fungos podem freqüentemente sair fora de controle e crescer. Então, no uso de biocidas, é importante usar aqueles que anulam o crescimento, ambos de bactérias e fungos (NACHTMAN, 1989).

Os três principais tipos de micróbios presentes nos fluidos de corte são: bactéria aeróbica, bactéria anaeróbica e fungos. Cândida (tipo de fungo, semelhante às leveduras) é também predominante em fluidos de corte contaminados com fungos (NACHTMAN, 1989). 
As bactérias aeróbicas causam queda do $\mathrm{pH}$ do fluido de corte e as bactérias anaeróbicas, incluindo as que provocam a redução de sulfatos, produzem sulfetos como o ácido sulfídrico, fermento e fungos (BURGES, 1997).

Segundo RUFFINO (1977), constata-se que a verdadeira causa das infecções não é a bactéria normalmente encontrada nos óleos graxos ou óleos solúveis e sim a bactéria existente na pele do operário. Portanto pode-se controlar algumas infecções melhorando a higiene pessoal do operador.

Com relação às dimensões das partículas na névoa gerada nos processos de corte, as partículas grandes (maiores que $8 \mu \mathrm{m}$ ) originam-se da pulverização e respingo de fluidos de corte, e névoas finas $(0,1$ a $1,0 \mu \mathrm{m})$ são produzidas no ponto de corte devido às forças de corte e alta temperatura (BURGES, 1997). Em um estudo, notou-se que há bactérias presentes em partículas maiores que $2 \mu \mathrm{m}$, enquanto que bactérias não são percebidas em partículas menores que $1 \mu \mathrm{m}$ (BURGES, 1997).

Além dos efeitos biológicos, a utilização dos fluidos de corte traz diversas desvantagens, tais como:

- $17 \%$ dos custos de produção são decorrentes da utilização de fluidos de corte (NOVASKI \& DÖRR, 1999) (SAHM \& SCHNEIDER, 1996). Segundo NARUTAKI et al. (1997), no final da década de 90, nos EUA o custo de usinagem é estimado em $\$ 300$ bilhões/ano e o custo associado com o uso de fluidos de corte é estimado aproximadamente $16 \%$ do custo de usinagem;

- HUSTON et al. (1998) presumem que dentro de algum tempo os custos associados à aquisição, à manutenção e à eliminação dos fluidos de corte excederão os beneficios do seu uso;

- Riscos ambientais de armazenamento e eliminação dos fluidos (NOVASKI \& DÖRR, 1999) (HEISEL et al., 1998);

- Adequação as leis ambientais;

- Saúde dos trabalhadores e qualidade do meio ambiente são objetivos claros das empresas (SAHM \& SCHNEIDER, 1996);

- Necessidade de separação dos cavacos dos fluidos de corte antes da refundição (NOVASKI \& DÖRR, 1999).

A industria de fluidos de corte está reformulando novas composições que são menos agressivas ao meio ambiente, por exemplo, sem chumbo, enxofre ou cloro que é muito usado no passado para melhorar a ação de lubrificação. É possivel que futuramente os fluidos de corte sejam mais seletos, escasso ou sem uso (NARUTAKI et al., 1997). 
Segundo NARUTAKI et al. (1997), o consumo de fluidos de corte tem sido reduzido drasticamente pelo uso de lubrificação por névoa. Entretanto a usinagem a seco ou com mínima quantidade de lubrificante tem sérios efeitos respiratórios no operador, conseqüentemente normas estão sendo fixadas para minimizar estes efeitos. Por exemplo, problemas provocados pelas poeiras produzidas (SAHM \& SCHNEIDER, 1996) ou por vapores inspirados.

\subsection{2 - Outros sistemas de refrigeração/lubrificação}

\subsubsection{1 - Usinagem a seco}

Segundo NARUTAKI et al. (1997), as vantagens da usinagem a seco são:

- custo menor;

- meio ambiente fabril mais saudável;

- melhor segurança do trabalhador;

- proteção contra efeitos químicos;

- isenção de sistema de bombeamento;

- isenção de sistema de coleta e filtração;

- não necessita armazenamento e disposição;

- talvez isenção de sistema de recirculação;

- isenção de efeitos fisiológicos no operador: irritação de pele (dermatite) ou efeitos de cultura de bactérias.

As opções disponiveis para obter as características desejáveis para usinagem a seco são (NARUTAKI et al., 1997):

1) Uso de ângulo de saída muito alto $\left(+30^{\circ}\right)$ em ferramentas de metal duro com cobertura reduz significantemente a energia global de corte;

2) Uso de ferramentas que são mais refratárias e conseqüentemente podem resistir às altas temperaturas geradas no corte;

3) Desenvolvimento de cobertura nas ferramentas de corte que podem resistir as altas temperaturas e/ou prover uma camada lubrificante para reduzir o atrito;

4) Reduzir a velocidade de corte significantemente para obter a desejada vida da ferramenta. 
Apesar das desvantagens da utilização dos fluidos de corte líquidos (mais utilizado industrialmente) (item 2.7.1) e vantagens da usinagem a seco, vários estudos da usinagem a seco mostram que, em algumas aplicações, a usinagem total a seco ainda não é possível (NOVASKI \& DÖRR, 1999) (HEISEL et al., 1998) (SAHM \& SCHNEIDER,1996). Por exemplo, na usinagem de alumínio e aços dúcteis, a não utilização da refrigeração provoca desgaste adesivo inaceitável; na usinagem de materiais altamente temperados, o aumento da temperatura é um fator limitante (NOVASKI \& DÖRR, 1999).

Nestes casos têm-se aplicado a usinagem quase a seco, através do sistema de mínima quantidade de lubrificante (MQL) (HEISEL et al., 1998) (SAHM \& SCHNEIDER, 1996).

\subsubsection{2 - Minimal Quantity of Lubricant (MQL)}

Pode ser chamada também de mínima quantidade de lubrificante, micropulverização (CETIM, 1999), lubrificação por névoa e lubrificação semi-seca. É um elo de ligação entre a usinagem a seco e a refrigeração convencional (HEISEL et al., 1998).

A lubrificação com quantidades mínimas (ou usinagem semi-seca) procura usar, no lugar de uma grande quantidade de fluido de corte, a menor quantidade possível de um óleo de alta eficiência que venha a produzir o mesmo efeito de lubrificação e refrigeração, mas este método semi-seco não produz refrigeração suficiente, não sendo adequado nas usinagens com grande geração de calor (NAKAGAWA, 2000). Portanto a técnica MQL age com base no princípio de utilização total, sem resíduos (SAHM \& SCHNEIDER, 1996)

Segundo CETIM (1999), normalmente o fluido, cujo volume é regulado com precisão por uma micro-bomba dosadora, é pulverizado por sopro através de um bico especial. E no decorrer da usinagem, é consumido sem deixar resíduos. A quantidade mínima de fluido, normalmente é menor que $100 \mathrm{ml} / \mathrm{h}$ e aplicada na maioria dos casos por um jato de ar (NOVASKI \& DÖRR, 1999).

Segundo HEISEL et al. (1998), nesta tecnologia a função de:

- lubrificação é assegurada pelo óleo;

- refrigeração é gerada pela convecção do jato de ar/óleo ou pela entalpia de evaporação. Esta ultima deve ser evitada, porque os produtos que podem eventualmente surgir da combustão são no mínimo suspeitos de serem prejudiciais à saúde;

- transporte de cavacos não é efetivo.

Existem dois tipos básicos de injeção do sistema MQL: externa (por meio de jatos) e interna (através de orifícios na ferramenta) (NOVASKI \& DÖRR, 1999) (Figura 11). 


\section{SISTEMA MQL - APLICAÇÃO DO FLUIDO}

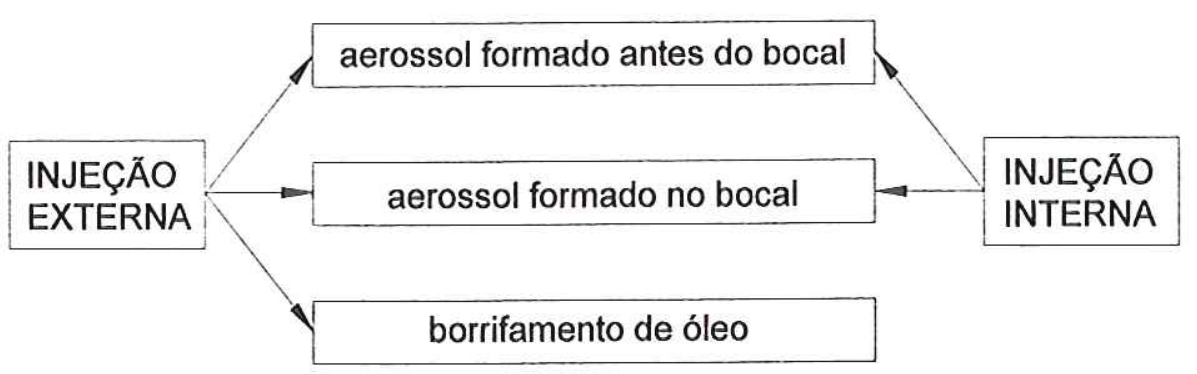

Figura 11 - Aplicações de fluido no sistema MQL

$\mathrm{Na}$ injeção externa, tem três maneiras de aplicação do fluido (NOVASKI \& DÖRR, 1999) (HEISEL et al., 1998):

1) O aerossol óleo/ar pode ser transportado por tubos formando um spray na ferramenta (NOVASKI \& DÖRR, 1999). Este é um sistema de pulverização de baixa pressão, onde o óleo é aspirado por uma corrente de ar e levado à superfície ativa como uma mistura (HEISEL et al., 1998). A vazão de óleo é aproximadamente 0,5 a $10 \mathrm{ml} / \mathrm{h}$, sendo principalmente emulsões, produzem uma atomização notável e somente podem ser dosados grosseiramente (HEISEL, et al., 1998);

2) Pode-se transportar óleo e ar separadamente até o bocal, onde ocorre a mistura pelo princípio de Venturi (NOVASKI \& DÖRR, 1999), de forma que as quantidades de ar e óleo podem ser ajustadas independentemente (HEISEL et al., 1998) (Figura 12). Segundo HEISEL et al. (1998), é um sistema de pressão e a mistura co-axial de óleo e ar no bocal previne enormemente a nebulosidade. O consumo de óleo é aproximadamente 10 a $100 \mathrm{ml} / \mathrm{h}$ e é o sistema mais utilizado (HEISEL et al., 1998) e

3) Um equipamento externo borrifa pequenas quantidades de óleo na ferramenta, em intervalos definidos (NOVASKI \& DÖRR, 1999) (HEISEL et al., 1998), normalmente através de bombas dosadoras com alimentação pulsatória de uma quantidade definida de lubrificante para a superfície ativa, sem ar (HEISEL et al., 1998). As taxas de fluxo são ajustáveis numa faixa entre 0,1 a $1 \mathrm{ml}$ por ciclo, com até 260 ciclos por minuto, sendo utilizados principalmente em processos intermitentes (HEISEL et al., 1998). 


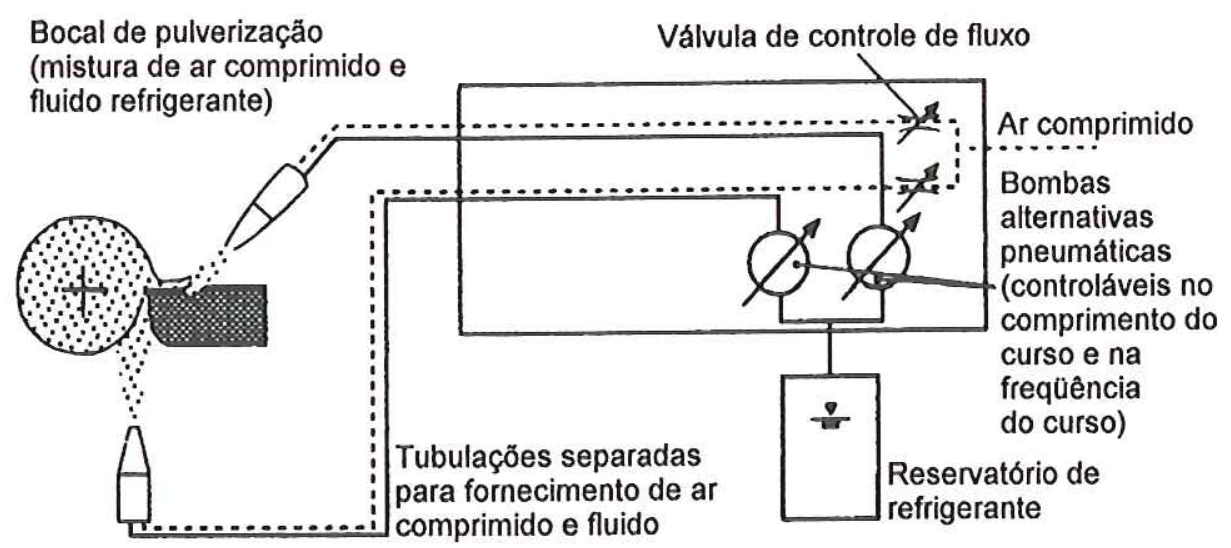

Figura 12 - Diagrama esquemático de um sistema MQL (HEISEL et al., 1998)

Nota-se que este último sistema de aplicação visa especialmente a lubrificação. Estes sistemas externos têm a vantagem de permitir a utilização de máquinas convencionais, com baixo custo e esforço. A desvantagem é a adaptação do posicionamento do bocal após troca automática da ferramenta (NOVASKI \& DÖRR, 1999).

A injeção interna é solução ideal e mais econômica nos casos de furação profunda. As vantagens são (NOVASKI \& DÖRR, 1999):

- o meio refrigerante irá chegar consistentemente até o local de corte;

- permite-se uma refrigeração adequada das arestas, mesmo em caso de furação com grandes profundidades $\mathrm{e}$

- o jato de ar ejetado auxilia a saída dos cavacos e também em menor eficiência, auxilia a dissipação de calor por conveç̧ão.

Os fluidos de corte normalmente utilizados são ésteres vegetais (ácidos graxos) derivados da cultura de oleaginosas para a industria. Estes óleos vegetais apresentam propriedades interessantes: fluidez, capacidade de reduzir os atritos e desgastes, ponto de fulgor elevado, boa resistência ao cisalhamento, inexistência de toxidade, biodegradabilidade e não contêm polinucleares aromáticos (não são tóxicos). O ponto fraco é seu baixo desempenho relativo à oxidação e à hidrólise, mas esta falta de estabilidade não é muito prejudicial, pois o produto não é reciclado (CETIM, 1999). Dificilmente utilizam-se óleos minerais e não é recomendável o uso de fluidos projetados para sistemas de refrigeração convencionais, porque pode haver forte atomização e vaporização, o que é prejudicial à saúde dos operários (HEISEL et al., 1998).

No caso do sistema MQL, os efeitos nos seres humanos devido ao contato com fluidos de corte são similares aos do item 2.7.1, deve-se ter importância o aspecto de assimilação 
pelos órgãos respiratórios. É necessário informações sobre o tamanho e o tipo de partículas do vapor, névoa e fumaça de óleo (HEISEL et al., 1998).

A formação de névoa de óleo é causada principalmente pela função dos sistemas MQL. O vapor de óleo é quase que somente desenvolvido por motivos térmicos, porque normalmente os óleos usados têm baixa vaporização. Como as temperaturas de corte desenvolvidas são elevadas (item 2.3.1), parte do óleo é queimada, evidente pelos cavacos fumegantes e pelo aparecimento de fumaça na ferramenta (HEISEL, et al., 1998).

Segundo HEISEL et al. (1998), os danos ao organismo humano somente podem ser causados pelas partículas que são capazes de entrar e permanecer nos pulmões ("partículas respiráveis"), cujo diâmetro varia entre 0,5 e $5 \mu \mathrm{m}$ (Figura 13). As partículas maiores não passam pelo nariz que age como um filtro, e a maioria das que têm diâmetro menor que 0,5 $\mu \mathrm{m}$ é expelida em grande quantidade, juntamente com o ar anteriormente inalado. Portanto somente partes da névoa e da fumaça de óleo pertencem ao grupo de partículas respiráveis. Não existem registros e estudos sobre os reais danos ao sistema respiratório.

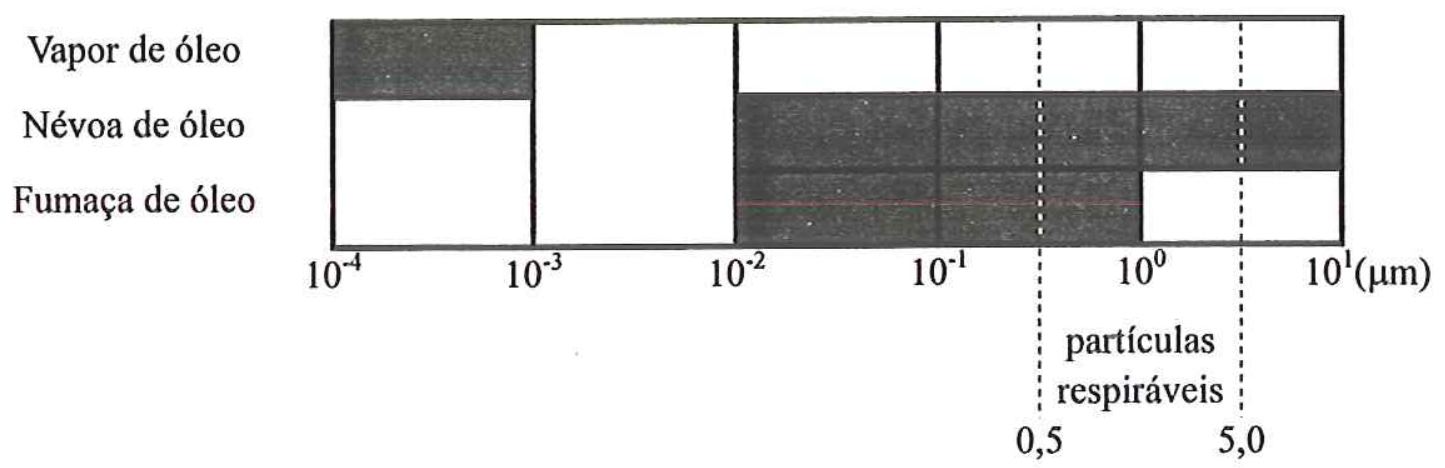

Figura 13 - Tamanho das partículas geradas no sistema MQL (HEISEL et al., 1998)

Devido ao potencial de riscos à saúde do operador ser grande, o aerossol formado devese restringir no ponto de aplicação, sem se propagar no ambiente. Segundo HEISEL et al. (1998), já existem várias possibilidades para reduzir o impacto ambiental:

- utilizar sistemas de sucção especiais tanto diretamente na área de processamento quanto na filtragem de todo o ar ambiente;

- utilizar bocais especiais que envolvem o jato pulverizado com um fluxo de ar;

- utilizar fluidos com vaporização e atomização mais baixos ou adicionar ao óleo básico aditivos anti-névoa. Com o objetivo de gerar gotas de óleo, durante a atomização, com diâmetros tão grandes quanto possível. 
Os benefícios da utilização do sistema MQL são:

- nenhuma necessidade de instalações técnicas para abastecimento, armazenamento, filtração e transporte dos fluidos de corte;

- custo reduzido de fluido de corte;

- cavaco quase livre de óleo, o óleo residual nos cavacos representa menos que $0,3 \%$ da massa do cavaco, permitindo sua fundição sem necessidade de limpeza, isto é, reciclagem (NOVASKI \& DÖRR, 1999) (SAHM \& SCHNEIDER, 1996);

- eficiência máxima das ferramentas de corte pela redução de atrito e aumento do desempenho de corte;

- um leve filme de óleo é mantido sobre a peça, protegendo-a contra corrosão (NOVASKI \& DÖRR, 1999);

- não aparecem as tensões causadas por grandes gradientes de temperatura, como no caso do fresamento com refrigeração convencional. Isto é especialmente importante no caso de materiais de corte frágeis (HEISEL et al., 1998);

- redução de tempo ocioso de máquina operatriz devido ao reduzido tempo de manutenção;

- diminuição do desgaste da ferramenta de corte;

- nenhum controle ou reprocessamento do fluido de corte usado;

- nenhum desperdício de fluido de corte;

- lugar de trabalho a seco e limpo;

- decomposição biológica;

- não tóxico, normalmente os fluidos utilizados são livres de resinas de "epoxy", cloro, nitritos, enxofre, fenol, metais pesados, silicones e biocidas;

- custo inferior em relação aos sistemas convencionais de aplicação de fluidos de corte. Por exemplo, num centro de usinagem os custos de investimentos, fixos e proporcionais são no total aproximadamente $20 \%$ menor (NOVASKI \& DÖRR, 1999).

Segundo NOVASKI \& DÖRR (1999), dentro de 5 a 10 anos, cerca de 20 a $50 \%$ da usinagem serão realizadas a seco ou quase seco.

\subsection{3 - Torneamento de ferro fundido}

No torneamento, devido ao contato contínuo entre e ferramenta e a peça, o acesso à área de corte é restrito. Portanto o fluido de corte deve ter baixo peso molecular. Geralmente os 
fluidos de corte mais recomendados são as emulsões (NACHTMAN, 1989). Os fluidos de corte líquidos e gasosos são aplicados diretamente sobre a região de corte, de tal maneira que o jato envolva as partes ativas da ferramenta e parte da peça em usinagem, conforme Figura 14 (RUFFINO, 1977). NACHTMAN (1989) recomenda vazão de fluido de corte de $20 \mathrm{l} / \mathrm{min}$ no torneamento de ferro fundido.

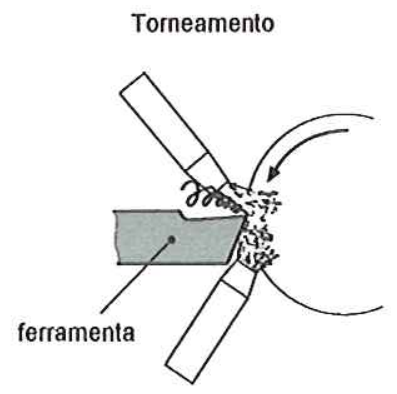

Figura 14 - Aplicação de fluido de corte no torneamento

Segundo RUFFINO (1977) (ver ANEXO B), através de apenas duas vias o fluido de corte líquido e gasoso pode atingir a região onde é necessário: superfície de saída (meio mais empregado) e de folga (meio que tem apresentado melhores resultados em ensaios comparativos) da ferramenta de corte.

Com relação à refrigeração do fluido de corte no torneamento de ferro fundido, TRENT (1991) realiza um experimento com velocidade de corte $\mathrm{v}_{\mathrm{c}}=183 \mathrm{~m} / \mathrm{min}$ e ferramenta de aço rápido com diferentes aplicações de fluido de corte (Figura 15 e Figura 16):

a) ar sobre a superfície de saída da ferramenta;

b) emulsão de óleo em água sobre a superfície de saída da ferramenta e

c) emulsão de óleo em água sobre a superfície de folga da ferramenta.

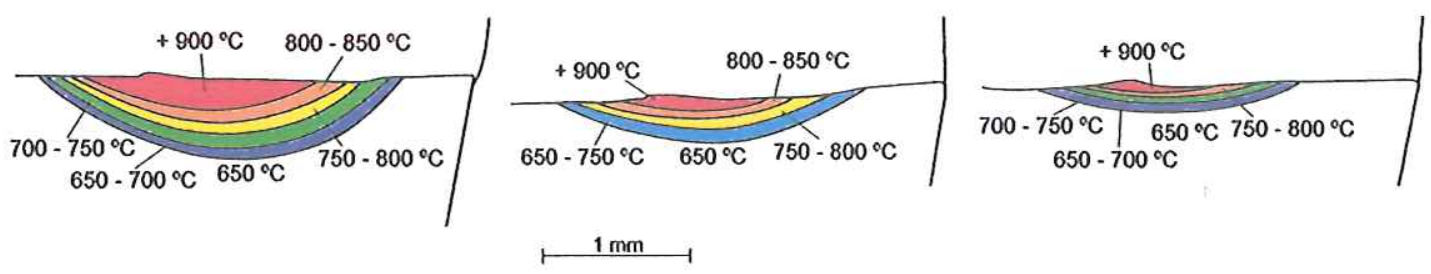

(a)

(b)

(c)

Figura 15 - Distribuição de temperatura da seção de uma ferramenta de aço rápido após usinagem de ferro fundido com $\mathrm{v}_{\mathrm{c}}=183 \mathrm{~m} / \mathrm{min}$ com diferentes aplicações de fluido de corte (TRENT, 1991) 


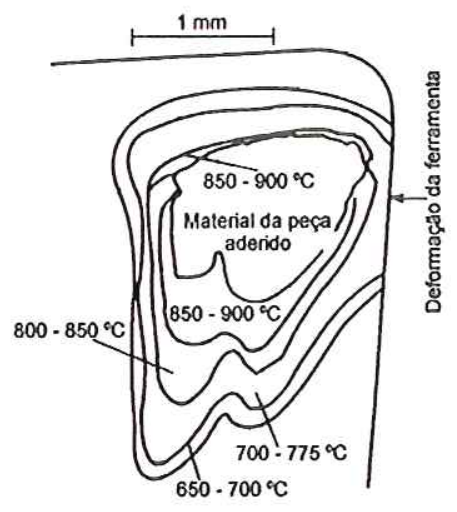

(a)
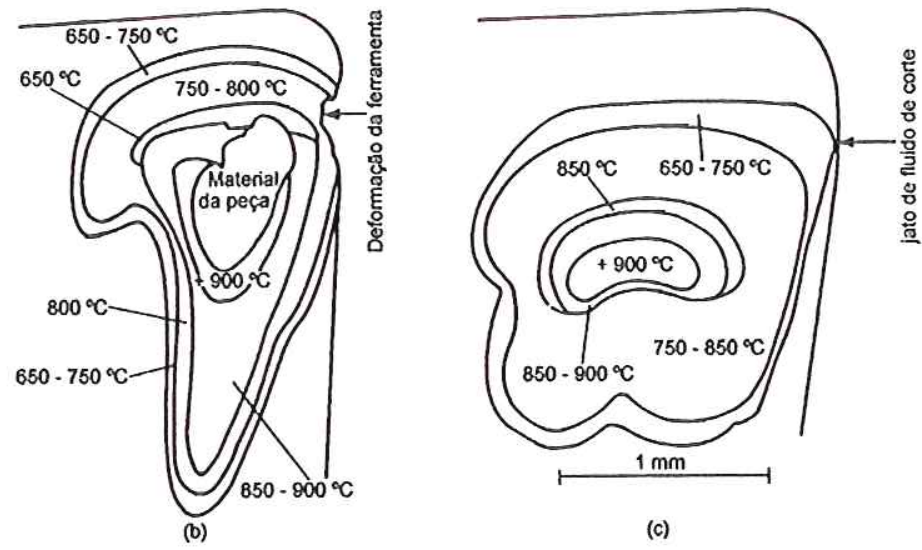

(c)

Figura 16 - Distribuição de temperatura na superfície de saída da Figura 15 (TRENT, 1991)

Segundo RUFFINO (1977), no torneamento de ferro fundido, os fluidos de corte recomendados são os óleos emulsionáveis. NACHTMAN (1989) especifica as emulsões de óleos de extrema pressão concentrados e óleos minerais concentrados com cloro. Mas segundo DINIZ et al. (1999) e BHATTACHARYYA et al. (1989), o ferro fundido cinzento deve ser usinado a seco ou com ar (às vezes com aspiração do cavaco), para evitar dano à máquina-ferramenta. Pois, segundo BHATTACHARYYA et al. (1989), fluidos de corte convencionais formam uma pasta fluida com cavacos. Uma solução é o uso de emulsões com detergentes (BHATTACHARYYA et al., 1989).

De acordo com SAHM \& SCHNEIDER (1996), as industrias alemãs utilizam a usinagem a seco por mais de trinta anos. Por exemplo: no início dos anos 60, o torneamento de discos de freio de ferro fundido cinzento é realizado a seco com ferramentas de nitreto de silício em velocidades de corte entre 600 e $1200 \mathrm{~m} / \mathrm{min}$.

O ferro pode ter duas reações com fluidos de corte que não ocorrem na usinagem de aço. Os veios de grafita no ferro fundido cinzento têm afinidade com óleo e podem extrair óleo das emulsões, portanto, deve-se controlar a concentração de óleo nas emulsões. Alguns ferros fundidos cinzentos contêm pequenas quantidades de metais alcalinos, tais como, cálcio, magnésio e cério. Os carbonetos destes elementos podem reagir com água dos fluidos de corte e formar quantidade infinitesimal de gás acetileno, que se pode sentir pelo odor. $\mathrm{O}$ mesmo ocorre na usinagem a seco, pela umidade relativa do ar (ASM, 1989b).

BHATTACHARYYA et al. (1989) afirmam que fluidos de corte podem resultar em trincas térmicas nas ferramentas de corte, especialmente em ferramentas de cerâmicas.

Pode-se direcionar fluido de corte somente na peça usinada quando esta não pode sofrer grandes temperaturas (BHATTACHARYYA et al., 1989). 


\section{8 - TÓPICOS PRINCIPAIS DA REVISÃO BIBLIOGRÁFICA}

Atualmente existem muitas linhas de pesquisa para aumentar a produtividade sem agredir o meio ambiente. Para realizar a revisão bibliográfica, encontram-se muitos trabalhos a respeito da usinagem a seco e com mínima quantidade de lubrificante (MQL), mas são trabalhos com poucos dados práticos. Precisa-se dominar mais a tecnologia MQL para diversos tipos de materiais usinados e materiais para ferramentas.

Atualmente, apesar da introdução de novos materiais e ligas na industria, o ferro fundido cinzento é muito utilizado, mas existem poucos trabalhos relacionados com alta velocidade de corte e lubrificação MQL. Existem algumas linhas de pesquisa no Japão, mas infelizmente os trabalhos freqüentemente estão na língua japonesa. 


\section{3 - TRABALHO EXPERIMENTAL}

Este capítulo descreve o comportamento de insertos de metal duro com cobertura e cerâmicos na operação de faceamento de acabamento com alta velocidade de corte em ferro fundido cinzento GG25. Realiza operações a seco e com aplicação de mínima quantidade de lubrificante (MQL).

Utiliza técnicas de Delineamento de Experimentos (planejamento do experimento e análise de dados) (CARPINETTI, 2000).

Adota as terminologias da Associação Brasileira de Normas Técnicas (ABNT), para descrever os movimentos e relações geométricas na usinagem dos metais (ABNT, 1989) e geometria da cunha de corte (ABNT, 1990).

\section{1 - MATERIAL USINADO}

Utiliza-se como corpo de prova nos ensaios um volante empregado em motor de 1000 centímetros cúbicos fabricado pela empresa Auto Pira S/A Ind. e Comércio de Peças. Utiliza volantes já usinados em desbaste, sendo refugos com porosidade em regiões diferentes daquelas usinadas em acabamento nos experimentos aqui descritos e analisados.

O material do volante é GG25, ferro fundido cinzento, que segundo KLEIN (1961), é chamado de ferro fundido de alta qualidade. Geralmente a estrutura típica de sua matriz é ferrítica-perlítica.

Na Figura 17, observam-se os veios (flocos) de grafita do material usinado sem ataque químico. Segundo CHIAVERINI (1984) e COLPAERT (1974), de acordo com as normas ASTM e AFS, o aspecto e a forma de apresentação da grafita são do tipo A, isto é, irregular desorientada. O comprimento médio dos veios de grafita é $n^{\circ} 4$ (COLPAERT, 1974). 


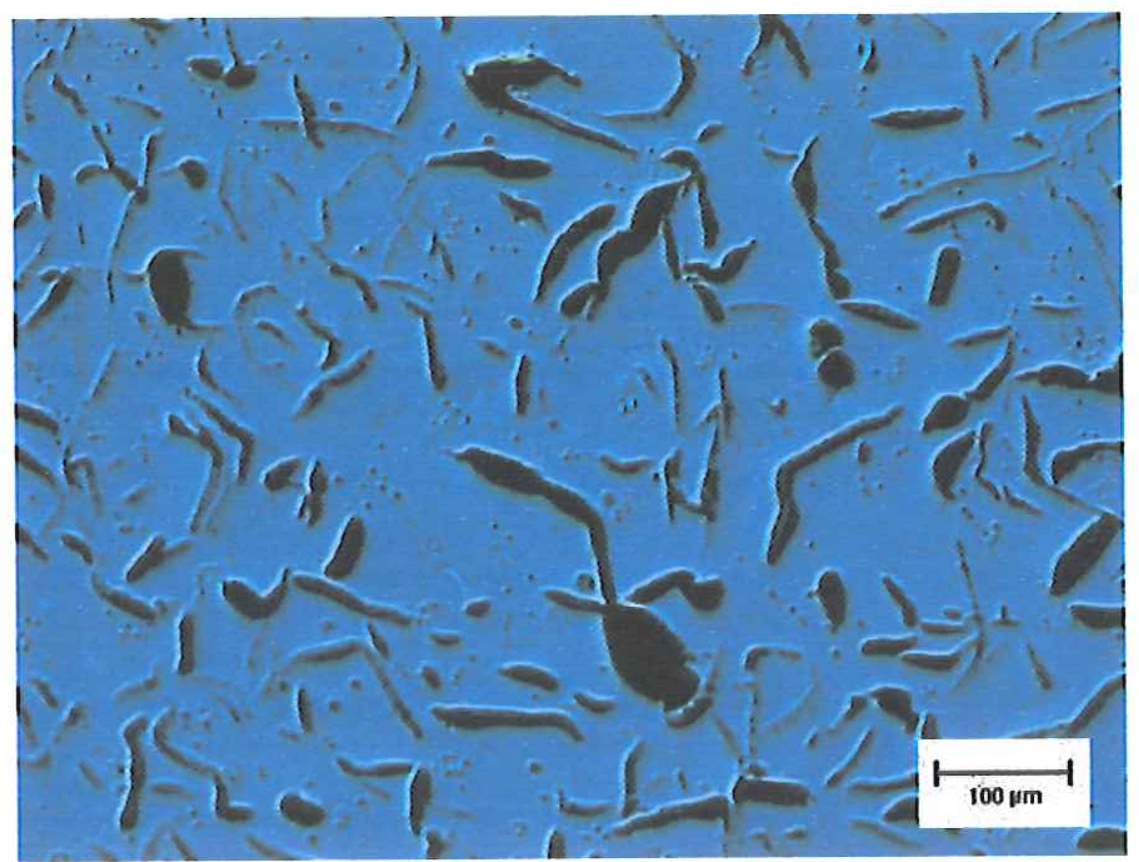

Figura 17 - Microestrutura do ferro fundido cinzento GG25, mostrando veios de grafita do tipo $\mathrm{A}$ (sem ataque, aumento $100 \mathrm{x}$ ). Exemplo de veios de tamanho $\mathrm{n}^{\circ} 4$.

Na Figura 18, tem-se a amostra atacada com nital $2 \%$. Pode-se observar que a matriz é predominantemente perlítica, tendo pouquíssima ferrita. Alguns aspectos de cementita e steadita são observados. 


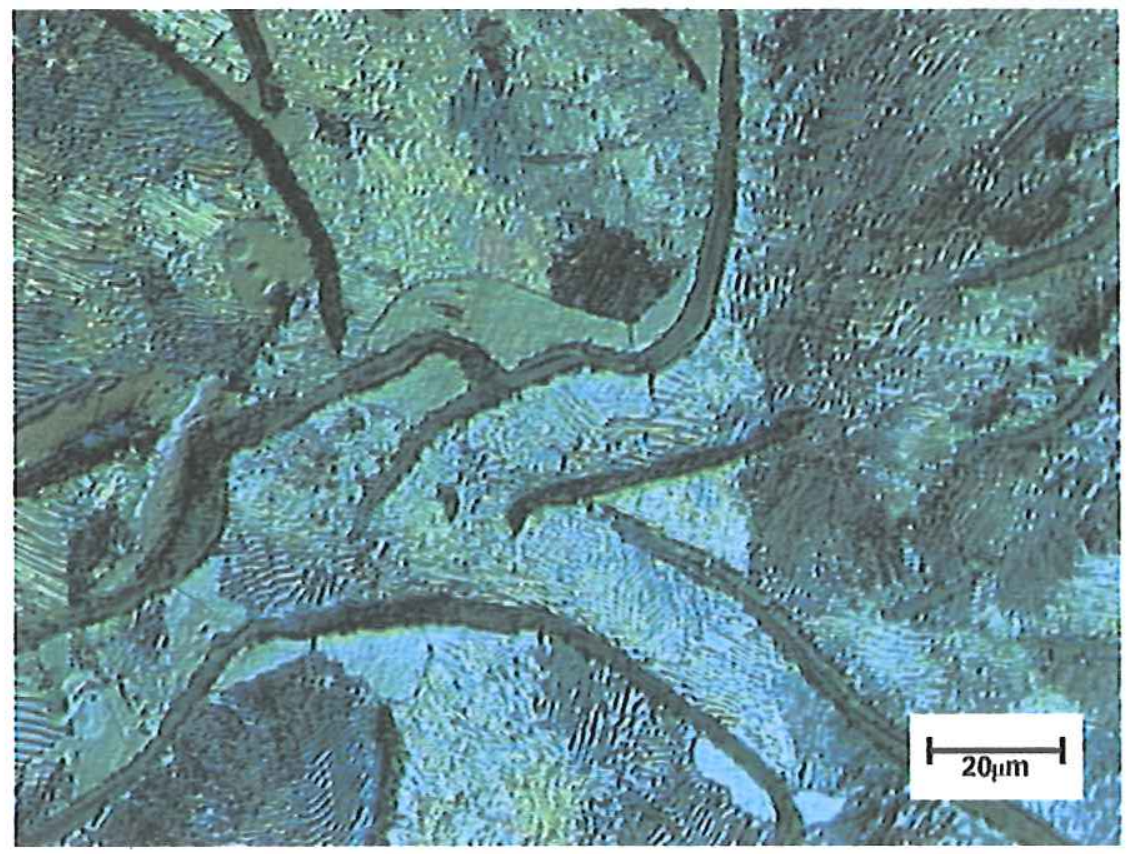

(a) Aumento $500 \mathrm{x}$

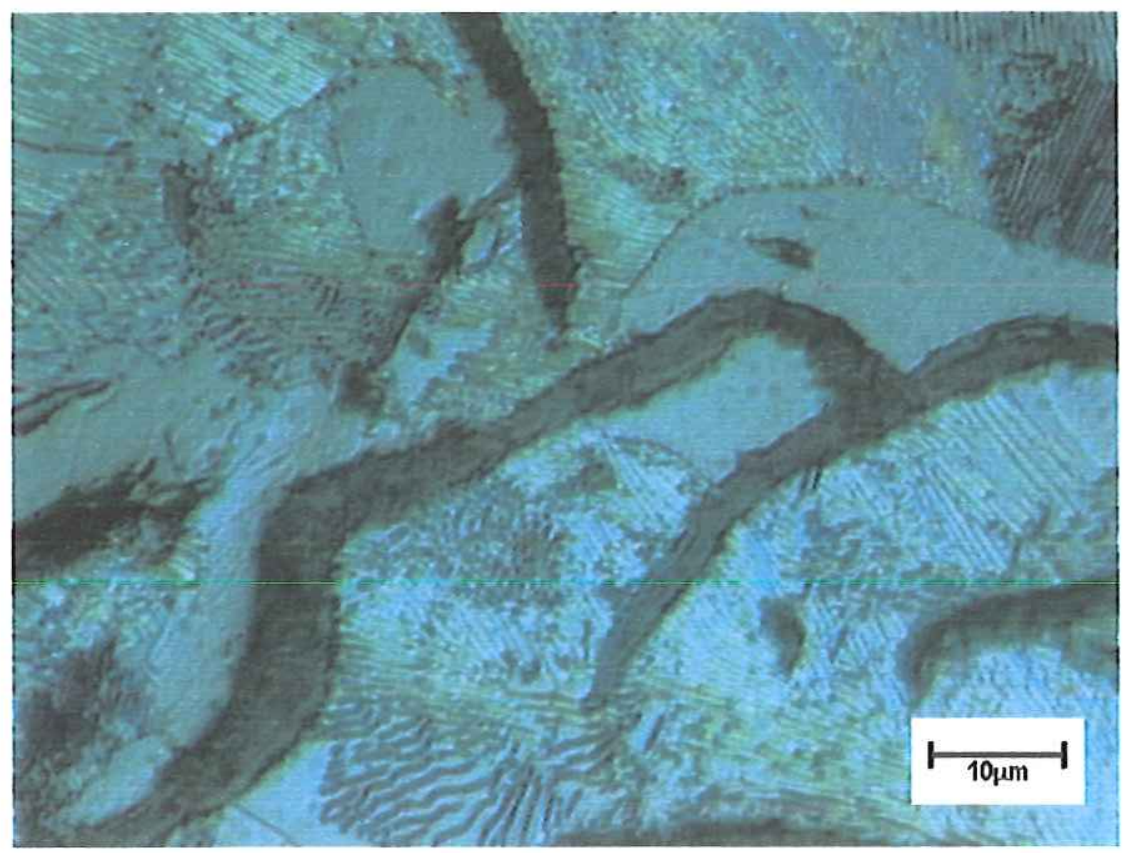

(b) Aumento $1000 \mathrm{x}$

Figura 18 - Microestrutura de uma matriz perlítica do ferro fundido cinzento GG25, mostrando os constituintes perlita e veios de grafita. Ataque: nital $2 \%$

As propriedades mecânicas do ferro fundido cinzento GG25 são mostradas na Tabela 4 (CHIAVERINI, 1984). 
Tabela 4 - Propriedades mecânicas do ferro fundido cinzento GG25 (DIN 1691)

\begin{tabular}{|c|c|}
\cline { 2 - 2 } \multicolumn{1}{c|}{} & GG25 \\
\hline Limite de Resistência à Tração $\left(\mathrm{kgf} / \mathrm{mm}^{2}\right)$ & 25 \\
\hline Limite de Resistência à Flexão $\left(\mathrm{kgf} / \mathrm{mm}^{2}\right)$ & $35 / 44$ \\
\hline Resistência à Compressão $\left(\mathrm{kgf} / \mathrm{mm}^{2}\right)$ & $70 / 100$ \\
\hline Dureza Brinell $(\mathrm{HB})$ & $200 / 260$ \\
\hline Módulo de Elasticidade $\left(\mathrm{kgf} / \mathrm{mm}^{2}\right)$ & $10,5 / 12$ \\
\hline Limite de Fadiga $\left(\mathrm{kgf} / \mathrm{mm}^{2}\right)$ & 0,35 a 0,50 do limite de resistência à tração \\
\hline
\end{tabular}

Realiza medições de dureza Brinell nos volantes: $(226 \pm 14) \mathrm{HB}$. De acordo com ASM (1989b), em função desta dureza, a matriz é de perlita grosseira.

As principais dimensões do volante estão mostradas no APÊNDICE III, onde os parâmetros utilizados para o ensaio são o diâmetro máximo $206 \mathrm{~mm}$ e o diâmetro mínimo $122 \mathrm{~mm}$. Na face onde realiza os ensaios, são medidos os valores de rugosidade antes dos ensaios em três regiões distintas: diâmetro menor (Ø 122 a 150 mm), médio (Ø 150 a 178 mm) e maior (Ø 178 a $206 \mathrm{~mm}$ ) (Tabela 5).

Tabela 5 - Valores da rugosidade superficial Ra do corpo de prova antes do ensaio

\begin{tabular}{|c|c|}
\cline { 2 - 2 } \multicolumn{1}{c|}{} & Rugosidade Média Ra $(\mu \mathbf{m})$ \\
\hline$\varnothing$ menor & $1,84 \pm 0,02$ \\
\hline$\varnothing$ médio & $1,79 \pm 0,02$ \\
\hline$\varnothing$ maior & $1,83 \pm 0,02$ \\
\hline
\end{tabular}

\section{$3.2-$ EQUIPAMENTOS}

A operação de torneamento realiza-se em um torno automático horizontal CNC Index, modelo GU 600. A rotação máxima da árvore é $5.000 \mathrm{rpm}$, a potência do motor em regime contínuo é $22 \mathrm{~kW}$ e em regime intermitente é $27,5 \mathrm{~kW}$. O diâmetro máximo de placa é 250 $\mathrm{mm}$, o comprimento nominal torneável é $600 \mathrm{~mm}$, sendo o diâmetro máximo de torneamento nominal igual a $210 \mathrm{~mm}$.

Elabora-se um programa de CNC para o torneamento dos volantes; o qual mostra-se no APÊNDICE IV.

Para realização dos ensaios com lubrificação MQL utiliza-se: 
- um compressor de ar Wetzel, modelo WT-10/200: pressão máxima 8,3 bar (120 psi ou $\left.8,5 \mathrm{kgf} / \mathrm{cm}^{2}\right)$;

- rotâmetro Digiflow, modelo K-12-V: pressão máxima 8 bar, fluido $\operatorname{ar}\left(21^{\circ} \mathrm{C}\right.$ e densidade 1298);

- aplicador pneumático Accu-Lube ${ }^{\circledast}$ de Micro-Lubrificação com dois bocais aplicadores (Figura 19): segundo fabricante, normalmente o sistema consome aproximadamente 40 $\mathrm{ml}$ de fluido por bocal a cada 8 horas em condições normais de trabalho. Funciona semelhante o esquema da Figura 12, isto é, a mistura óleo/ar ocorre no bocal. $\mathrm{O}$ deslocamento do fluido de corte é por gravidade até a bomba pneumática (item 5). O gerador de freqüência (item 4) regula a freqüência com que a bomba pneumática realiza seu percurso, sendo este percurso regulado pelo item 6 . No item 5, não aparece descrito, mas existe o ajuste individual de fluxo de ar.

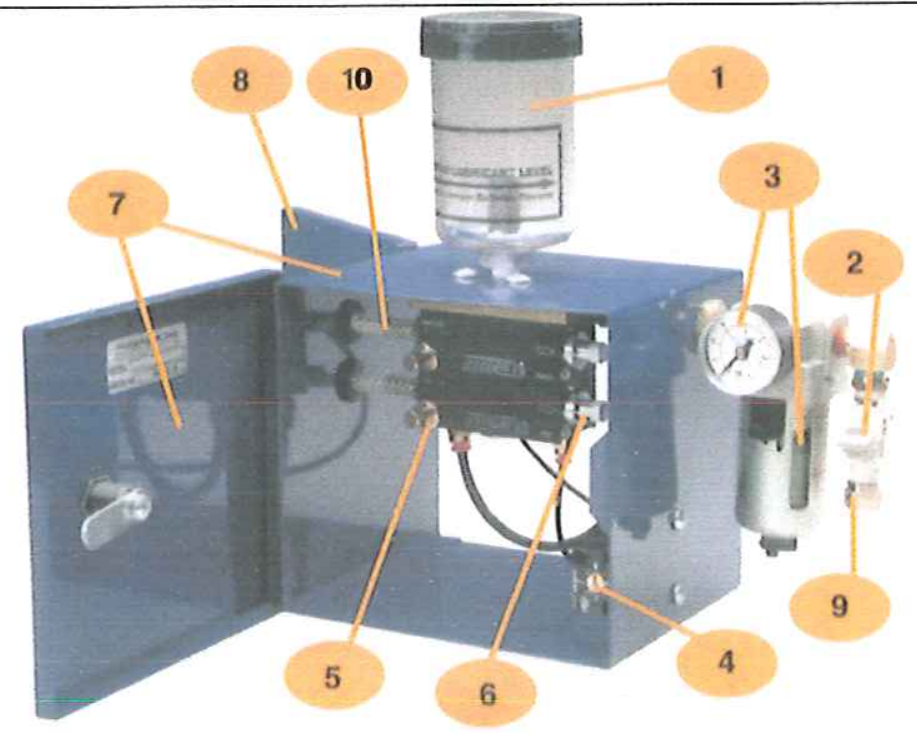

1. Reservatório $300 \mathrm{ml}$;

2. Registro de acionamento;

3. Manômetro e filtro de ar (deve atuar entre 80 e 150 psi ou 5,6 e 10,5 kgf/ $\mathrm{cm}^{2}$ );

4. Gerador de freqüência (sentido horário aumenta freqüência);

5. Bomba pneumática de ajuste individual;

6. Ajuste do fluxo de lubrificante;

7. Caixa metálica;

8. Furos de montagem ou bases magnéticas para fixação rápida;

9. Entrada de ar (mínimo 80 psi ou $5,6 \mathrm{kgf} / \mathrm{cm}^{2}$ );

10. Saída para o bocal aplicador.

Figura 19 - Aplicador Accu-Lube $e^{\circledast}$ de Micro-Lubrificação 
O desgaste dos insertos mede-se em um microscópio E. Leitz Wetzlar, com sistema de medição na lente ocular do microscópio, com resolução de $0,278 \mu \mathrm{m}$.

Para medição da rugosidade superficial dos volantes usinados utiliza-se um rugosímetro portátil Taylor-Hobson com apalpador, modelo Surtronic 3P.

Para realização das fotografias de microscopia eletrônica, para identificação dos mecanismos e tipos de desgaste, utilizou-se um microscópio eletrônico de varredura (SEM) Zeiss, modelo DSM 960.

As micrografias do material da peça são realizadas em um microscópio ótico, modelo Axiotech da marca Zeiss.

\section{3 - LUBRIFICANTE}

No sistema de lubrificação MQL utiliza-se o lubrificante natural Accu-Lube ${ }^{\circledast}$ LB-1000. Suas principais características são: óleo natural de alta performance, com aditivos Extrema Pressão, para operações severas; excelente lubricidade; não recomendado para uso em titânio e deve ser removido antes de tratamento térmico.

\section{4 - FERRAMENTAS}

Utilizam-se ferramentas de metal duro com cobertura (maior tenacidade) e de cerâmica (maior resistência ao desgaste) do fabricante Sandvik.

Primeiro escolhem-se os insertos de cerâmica, que é o material para ferramenta mais comum para torneamento de ferro fundido, e depois os insertos de metal duro.

Segundo o fabricante, as principais características do inserto para torneamento de acabamento de ferro fundido cinzento são: ângulo de folga nulo e sem quebra-cavacos.

A recomendação de primeira escolha de inserto para o torneamento de acabamento de ferro fundido são as cerâmicas $\mathrm{CC} 650$ (cerâmica mista à base de $\mathrm{Al}_{2} \mathrm{O}_{3}$ com TiC) e CC 620 (cerâmica pura à base de $\mathrm{Al}_{2} \mathrm{O}_{3}$ com pequena adição de $\mathrm{ZrO}_{2}$ ).

Escolhe-se a forma de inserto quadrado com raio de ponta $0,8 \mathrm{~mm}$ (não existe nenhuma restrição quanto à forma do inserto no torneamento de acabamento).

A escolha do inserto de metal duro com cobertura baseia-se nas mesmas condições geométricas do inserto de cerâmica (para efeito de comparação do desempenho de corte). 
As ferramentas são escolhidas para trabalharem em condições extremas, isto é, em velocidades de corte superiores das recomendadas, sendo que a ferramenta utilizada de metal duro com cobertura não é a primeira opção de escolha, conforme o fabricante.

Na Tabela 6 estão as condições de usinagem para torneamento de acabamento, segundo o fabricante dos insertos.

Tabela 6 - Condições de usinagem para torneamento de acabamento

\begin{tabular}{|c|c|c|}
\cline { 2 - 3 } \multicolumn{1}{c|}{} & $\mathbf{f}(\mathbf{m m} /$ volta) & $\mathbf{a}_{\mathbf{p}}(\mathbf{m m})$ \\
\hline Acabamento Fino & $0,05-0,15$ & $0,25-2,0$ \\
\hline Acabamento & $0,1-0,3$ & $0,5-2,0$ \\
\hline
\end{tabular}

\subsection{1 - Insertos de Cerâmica}

A ferramenta escolhida de cerâmica é o inserto CC 650 código SNGA 120408T01020, cujas dimensões estão no APÊNDICE V.

Esta classe de inserto de cerâmica $\mathrm{CC} 650$ é uma cerâmica mista à base de alumina $\left(\mathrm{Al}_{2} \mathrm{O}_{3}\right)$ com carboneto de titânio (TiC), que segundo KATSUMURA et al. (1993), é ideal para usinagem de ferro fundido cinzento e tem poucas aplicações com outros materiais.

Segundo o fabricante, na Tabela 7 são mostradas as condições de usinagem recomendadas no torneamento de ferro fundido cinzento segundo catálogo do fabricante.

Tabela 7 - Condições de usinagem recomendados pelo fabricante do inserto de cerâmica CC650

\begin{tabular}{|c|c|c|c|}
\hline $\mathbf{v}_{\mathbf{c}}(\mathrm{m} / \mathbf{m i n})$ & 700 & 600 & 500 \\
\hline $\mathbf{f}(\mathbf{m m} /$ volta $)$ & 0,10 & 0,25 & 0,40 \\
\hline
\end{tabular}

No caso de torneamento de acabamento o fabricante recomenda para este inserto as seguintes condições de usinagem: $r_{\varepsilon}=1,2 \mathrm{~mm} ; a_{p}=1,5 \mathrm{~mm} ; f=0,3 \mathrm{~mm} /$ volta e $v_{c}=550 \mathrm{~mm} / \mathrm{min}$.

Portanto utiliza-se um inserto recomendado, mas em suas condições extremas de utilização, isto é, com velocidade de corte até $143 \%$ superior que o máximo recomendado. 


\subsection{2 - Insertos de Metal Duro}

Para as condições de corte desejadas, isto é, torneamento de ferro fundido, a classe de metal duro recomendada é o grupo ISO K. A ferramenta escolhida é o inserto GC 3015 código SNMA 120408-KR (fabricante Sandvik) (sem quebra-cavacos), cujas dimensões estão no APÊNDICE V.

Embora a geometria sem quebra-cavacos escolhida seja indicada somente para desbaste, optou-se por essa para possibilitar maior robustez, já que a velocidade de corte dos experimentos é muito acima da recomendada em catálogo do fabricante.

Esta classe de inserto de metal duro com cobertura GC 3015 é constituída de três camadas de cobertura aplicadas pelo processo CVD:

- a primeira camada é o carbonitreto de titânio (TiCN) - camada mais espessa;

- a segunda camada é o óxido de alumínio $\left(\mathrm{Al}_{2} \mathrm{O}_{3}\right)$ - camada de espessura média;

- a terceira camada é o nitreto de titânio (TiN) - camada externa fina (cor amarelodourada).

A espessura total das camadas é de $10 \mu \mathrm{m}$.

Segundo o fabricante, este tipo de inserto é ideal ( $1^{\mathrm{a}}$ escolha) para torneamento de desbaste de ferro fundido cinzento (alta resistência à tensão). Na Tabela 8 são mostradas as condições de usinagem recomendadas para o torneamento de ferro fundido cinzento segundo o catálogo do fabricante.

Tabela 8 - Condições de usinagem recomendadas pelo fabricante do inserto de metal duro GC 3015

\begin{tabular}{|c|c|c|c|}
\hline $\mathbf{v}_{\mathbf{c}}(\mathbf{m} / \mathbf{m i n})$ & 305 & 240 & 185 \\
\hline $\mathbf{f}(\mathbf{m m} /$ volta $)$ & 0,1 & 0,3 & 0,6 \\
\hline
\end{tabular}

Para o fabricante não existe classe de metal duro com cobertura ideal para o torneamento de acabamento de ferro fundido cinzento. O inserto mais indicado é GC $3005 \mathrm{KF}$ tipo G (com quebra-cavacos): $r_{\varepsilon}=0,8 \mathrm{~mm} ; a_{p}=0,5 \mathrm{~mm} ; f=0,2 \mathrm{~mm} /$ volta e $v_{c}=250 \mathrm{~mm} / \mathrm{min}$. A forma quadrada do inserto também não é recomendada no acabamento, as formas recomendadas são: rômbica $\left(55^{\circ} \mathrm{e} 80^{\circ}\right)$, triangular $60^{\circ}$ e trigonal $80^{\circ}$.

Portanto utiliza-se um inserto em suas condições extremas de utilização, isto é, não recomendado e com velocidade de corte até 457 \% superior que o máximo recomendado. 


\section{5 - PORTA FERRAMENTAS}

O porta ferramentas utilizado é o mesmo para os dois tipos de insertos, seu código segundo o fabricante Sandvik é CSSNL-2525M-12IC, cujas dimensões estão no APÊNDICE V. Suas principais características são: sistema de fixação por grampo de topo e pelo furo; tipo de suporte $45^{\circ}$; ângulo de folga do inserto $0^{\circ}$; sentido da ferramenta L (esquerda) e comprimento da aresta de corte $12 \mathrm{~mm}$.

\section{6 - PLANEJAMENTO e PROCEDIMENTO EXPERIMENTAL}

\subsection{1 - Preparação do corpo de prova}

No APÊNDICE III tem-se a geometria do volante, como no torno CNC utilizado não é possível utilizar castanha invertida para fixação do volante na placa, desenvolveu-se uma fixação especial (Figura 20). Este dispositivo é fabricado com três furos passantes roscados, distribuídos em uma circunferência a $120^{\circ}$ um do outro. Os parafusos utilizados são com cabeça com sextavado interno.

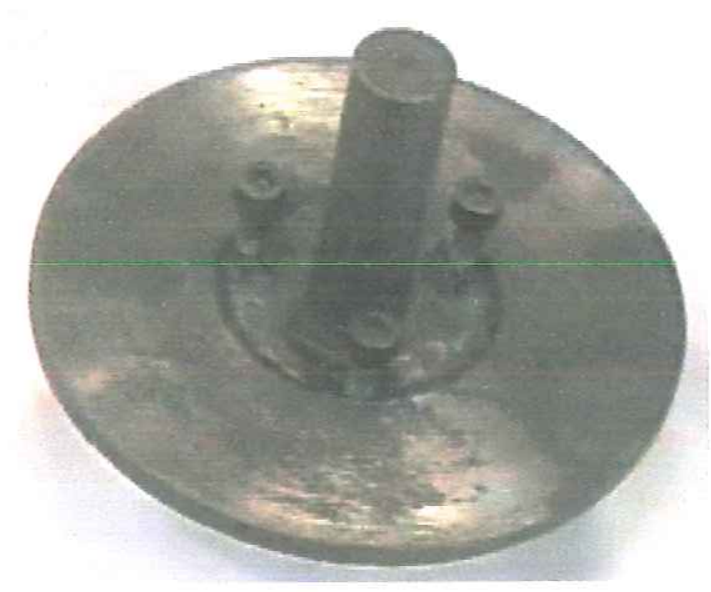

(a) Lado para fixação do volante

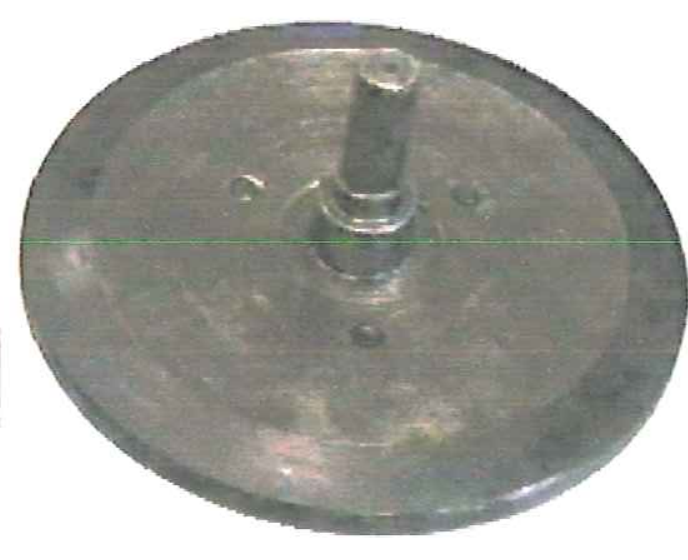

(b) Lado para fixação na placa do torno

Figura 20 - Dispositivo para fixação do volante na placa do torno

Para realizar a operação de furação no volante há necessidade de utilizar um acessório para obter boa tolerância de concentricidade, coaxilidade e localização dos três furos em relação ao furo central do volante. Utiliza-se um cone para centralizar o volante na base da furadeira. 


\subsection{2 - Matriz de experimentos}

Todo experimento é um teste. Variações propositais são realizadas nas variáveis de entrada ou de controle de um processo ou sistema, para observar e identificar as razões de variação de resposta ou variável de saída, mas variáveis não controláveis estão no processo. Portanto o correto planejamento do experimento visa minimizar as variáveis não controláveis (CARPINETTI, 2000), para eliminar os erros sistemáticos e acidentais (aleatórios) (PIMENTEL, 1987).

Nesta etapa através de procedimentos corretos, existe a possibilidade de minimização das variáveis não controláveis, sendo principalmente neste experimento: operador e material do volante. Portanto é sempre o mesmo operador para as mesmas funções, tais como, fixação do volante na placa, medição do desgaste do inserto e medição de rugosidade. No caso do material do volante, o ideal é realizar aleatoriamente os ensaios, isto é, cada combinação de condições aleatoriamente, mas devido à complexidade, executa-se a operação de torneamento em cada volante no mínimo por dois insertos diferentes.

Então, o planejamento de experimento é organizado e conduzido, incluindo a definição das variáveis dependentes e independentes, número de testes e condições para a realização dos testes.

São realizados ensaios de pré-teste para estabelecer as condições de usinagem. O torneamento é realizado com velocidade de corte constante. Portanto para o diâmetro mínimo Ø $122 \mathrm{~mm}$ do volante e rotação máxima do torno CNC $5000 \mathrm{rpm}$, a máxima velocidade de corte possível é $\mathrm{v}_{\mathrm{c} \max }=1916,37 \mathrm{~m} / \mathrm{min}$. Adotou como velocidade de corte máxima de ensaio $1700 \mathrm{~m} / \mathrm{min}$.

No ensaio de pré-teste utilizou-se avanço variando entre 0,08 a $0,1 \mathrm{~mm} /$ volta e profundidade de usinagem constante de $0,5 \mathrm{~mm}$, baseado na Tabela 6 .

A Tabela 9 mostra as condições de usinagem adotadas nos ensaios.

Tabela 9 - Condições de usinagem adotadas

\begin{tabular}{|c|c|c|}
\hline Velocidade de Corte (m/min) & Avanço (mm/volta) & Profundidade de Usinagem (mm) \\
\cline { 1 - 1 } 1000 & 0,08 & \multirow{2}{*}{0,5} \\
\cline { 1 - 1 } 1350 & & \\
\cline { 1 - 1 } 1700 & 0,10 & \\
\hline
\end{tabular}


Com as condições de usinagem definidas, monta-se a matriz de experimentos (Tabela 10).

Tabela 10 - Matriz de Experimentos

\begin{tabular}{|c|c|c|c|c|c|}
\hline \multirow{2}{*}{$\begin{array}{l}\text { Material da } \\
\text { Ferramenta }\end{array}$} & \multirow{2}{*}{$\begin{array}{l}\text { Velocidade } \\
\text { de Corte } \\
(\mathrm{m} / \mathrm{min})\end{array}$} & \multirow{2}{*}{$\begin{array}{c}\text { Avanço } \\
\text { (mm/volta) }\end{array}$} & \multirow{2}{*}{$\begin{array}{c}\text { Profundidade } \\
\text { de Usinagem } \\
\text { (mm) }\end{array}$} & \multicolumn{2}{|c|}{ Lubrificação } \\
\hline & & & & $\begin{array}{l}\text { Vazão Óleo } \\
(\mathrm{ml} / \mathrm{h})\end{array}$ & $\begin{array}{l}\text { Vazão Ar } \\
\left(\mathrm{m}^{3} / \mathrm{h}\right)\end{array}$ \\
\hline Metal Duro & 1000 & 0,08 & 0,5 & \multicolumn{2}{|c|}{ SECO } \\
\hline Metal Duro & 1350 & 0,08 & 0,5 & \multicolumn{2}{|c|}{ SECO } \\
\hline Metal Duro & 1700 & 0,08 & 0,5 & \multicolumn{2}{|c|}{ SECO } \\
\hline Metal Duro & 1350 & 0,08 & 0,5 & 12 & 18 \\
\hline Metal Duro & 1700 & 0,08 & 0,5 & 12 & 18 \\
\hline Cerâmica & 1700 & 0,08 & 0,5 & \multicolumn{2}{|c|}{ SECO } \\
\hline Cerâmica & 1700 & 0,10 & 0,5 & \multicolumn{2}{|c|}{ SECO } \\
\hline Cerâmica & 1700 & 0,10 & 0,5 & 10 & 9 \\
\hline Cerâmica & 1700 & 0,10 & 0,5 & 10 & 18 \\
\hline Cerâmica & 1700 & 0,10 & 0,5 & 20 & 9 \\
\hline Cerâmica & 1700 & 0,10 & 0,5 & 20 & 18 \\
\hline
\end{tabular}

\subsection{3 - Montagem da Banca de Ensaios}

A partir das dimensões do volante, do sistema de fixação e das condições de usinagem efetua-se a programação CNC (APÊNDICE IV).

O ensaio consiste basicamente de duas etapas: torneamento a seco e com MQL.

\subsubsection{1 - Montagem do equipamento de MQL}

Primeiramente testa-se o compressor para verificar a pressão máxima e a pressão mínima de trabalho: $P_{\text {máxima }}=8,5 \mathrm{kgf} / \mathrm{cm}^{2}$ e $P_{\text {mínima }}=7,5 \mathrm{kgf} / \mathrm{cm}^{2}$, para satisfazer condições de aplicação do Aplicador Accu-Lube ${ }^{\circledast}$ de Micro-Lubrificação (Figura 19). A vazão máxima de ar medida com rotâmetro é $18 \mathrm{~m}^{3} / \mathrm{h}$.

Fixa-se o Aplicador Accu-Lube ${ }^{\circledast}$ de Micro-Lubrificação magneticamente à base do torno $\mathrm{CNC}$ e conecta ao compressor através de mangueira flexível. Existem dois ajustes para a 
vazão de óleo desejada (um para cada bocal). No ensaio utiliza-se somente um bocal. As condições de trabalho do Aplicador Accu-Lube ${ }^{\circledR}$ de Micro-Lubrificação são:

- vazão de óleo: 10,12 e $20 \mathrm{ml} / \mathrm{h}$

- vazão de entrada de ar: 9 e $18 \mathrm{~m}^{3} / \mathrm{h}$

- pressão no manômetro de entrada de ar: varia entre 5,8 a $6,0 \mathrm{kgf} / \mathrm{cm}^{2}$

A vazão de óleo é medida com o auxilio de uma proveta (graduada em $\mathrm{ml}$ ).

O bocal flexível é fixado magneticamente sobre o cabeçote porta-ferramenta do torno $\mathrm{CNC}$, direcionado para a superfície de saída do inserto (Figura 21).

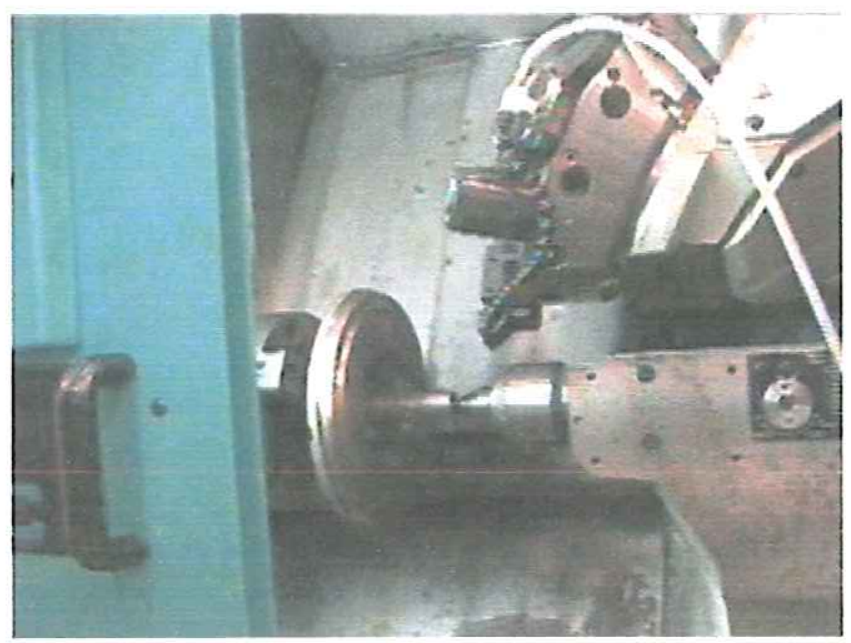

(a) montagem

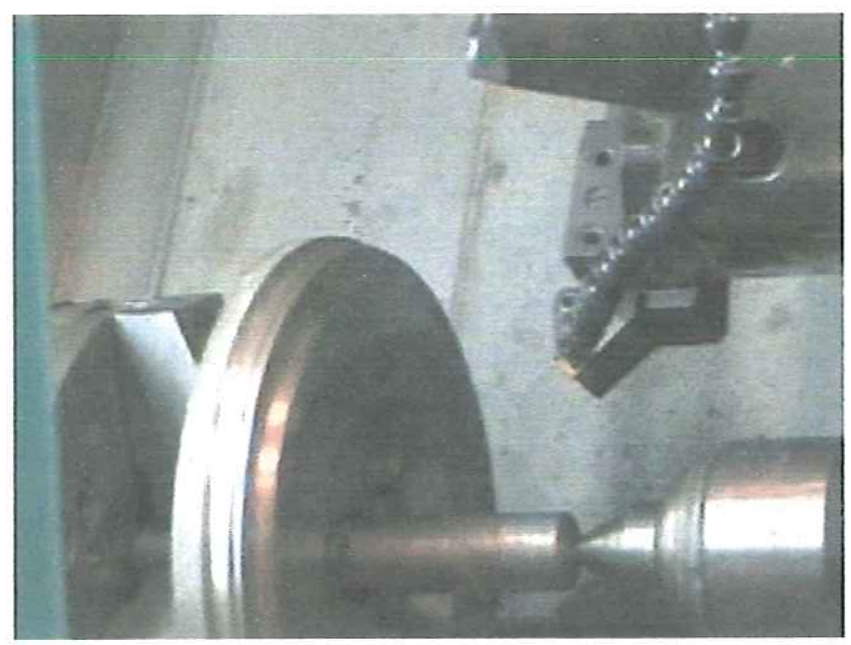

(b) detalhe

Figura 21 - Montagem do ensaio experimental com MQL (1 bocal) 


\subsection{4 - Medição do desgaste de flanco dos insertos}

Devido ao ângulo de folga do inserto ser nulo, para efetuar a medição do desgaste máximo de flanco $V_{B \max }$ conforme o item 2.3.3, simplesmente coloca-se o inserto verticalmente sobre a base do microscópio.

Para medir o desgaste de flanco em milímetros, há necessidade de calibrar o sistema de referência. Com a escala milimétrica de um paquímetro calibram-se os dois anéis graduados do microscópio usando a lente de 65 vezes de aumento. Em meio milímetro contam-se 18 voltas e 100 divisões na escala do medidor tipo durômetro Vickers. Sendo assim, cada divisão corresponde a $0,278 \mu \mathrm{m}$.

\subsection{5 - Medição da rugosidade superficial}

Para medição da rugosidade superficial dos volantes usinados utiliza-se um rugosímetro portátil com apalpador. A rugosidade medida é em $\mathrm{Ra}(\mu \mathrm{m})$ na direção radial do volante, pois a orientação dos sulcos é concêntrica (faceamento).

Utiliza-se valor de cut-off de $0,8 \mathrm{~mm}$, mantido o mesmo para todas as medições.

Para obter-se um valor médio de rugosidade que representa toda a superfície usinada, mediu-se em três regiões distintas (item 3.1): diâmetro menor (Ø 122 a 150 mm), médio (Ø 150 a $178 \mathrm{~mm}$ ) e maior (Ø 178 a $206 \mathrm{~mm}$ ) (Figura 22). Em cada região realizam-se medições em três pontos eqüidistantes $120^{\circ}$, sendo que em cada ponto fazem-se três medições. 


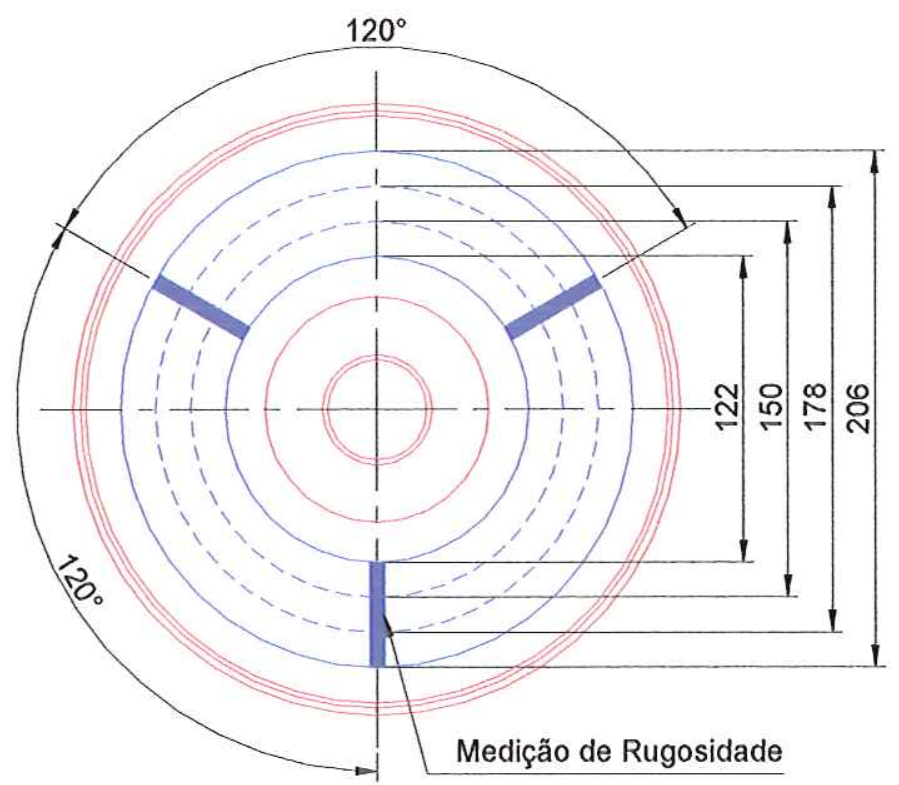

Figura 22 - Medição de rugosidade no volante usinado

Coloca-se o rugosímetro sobre uma base de madeira paralela ao volante. A face do suporte é perpendicular ao eixo de simetria do volante-suporte, que garante o paralelismo.

Nos primeiros ensaios, a cada passe de faceamento são realizadas medições de rugosidade assim como o desgaste do inserto, mas posteriormente verificou-se a não necessidade de realizar tais medições a cada passe, pois em certas situações a variação do desgaste é mínima.

Os seguintes cuidados são providenciados: freqüente ajuste vertical do apalpador do rugosímetro (espessura do volante diminui); e sempre o mesmo operador realiza as medições, para evitar erros acidentais ou aleatórios (PIMENTEL et al., 1987).

No APÊNDICE II, tem-se duas equações para cálculo teórico da rugosidade superfícial média Ra ideal em função do raio de ponta da ferramenta $r_{\varepsilon}$ e avanço f: uma exata e outra simplificada (para cálculos práticos). Existe também um gráfico de Ra em função de $f$ e $r_{\varepsilon}$ (Figura 48).

Os valores de rugosidade superficial ideal Ra em função do raio de ponta do inserto e avanço estão na Tabela 11. Calculam-se pelas duas equações (exata e simplificada) do APÊNDICE II e pela tabela de conversão de AGOSTINHO et al. (1977). 
Tabela 11 - Valores de Ra ideal em função do raio de ponta do inserto e avanço

\begin{tabular}{|c|c|c|c|}
\hline \multicolumn{4}{|c|}{ raio de ponta $\mathbf{r}_{\mathbf{\varepsilon}} \mathbf{0 , 8} \mathbf{~ m m}$} \\
\hline \multirow{2}{*}{$\begin{array}{c}\text { avanço f } \\
(\mathbf{m m} / \text { volta })\end{array}$} & Exata & Simplificad $(\mu \mathbf{m})$ \\
\cline { 2 - 4 } & 0,257 & 0,257 & $\begin{array}{c}\text { AGOSTINHO et al. } \\
(1977)\end{array}$ \\
\hline 0,08 & 0,401 & 0,401 & 0,316 \\
\hline 0,10 & & & 0,490 \\
\hline
\end{tabular}

\subsection{6 - Preparação dos insertos para análise no microscópio eletrônico de varredura (SEM)}

Os insertos são colados em suportes de alumínio, para serem fixadas à base do microscópio eletrônico de varredura (SEM) (Figura 23). Uma tinta a base de prata é aplicada em pequenas regiões entre o inserto e o suporte de alumínio para estabelecer um contato elétrico mais eficiente. Depois ocorre a deposição de um filme de ouro sobre o conjunto inserto/suporte, necessário para aumentar a condutividade elétrica.

As fotografias são feitas das arestas desgastadas dos insertos no intuito de se estudar os mecanismos de desgastes predominantes. As ampliações são ajustadas para melhor visualização.

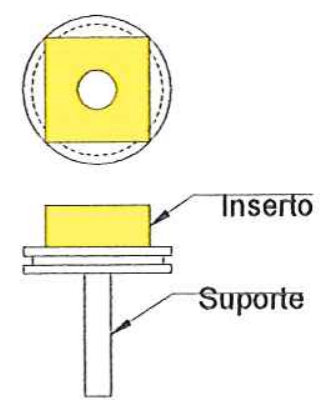

Figura 23 - Inserto colado em suporte de alumínio para fixação no microscópio eletrônico de varredura 


\subsection{7 - Preparação das amostras para análise de microestrutura do material usinado}

Para preparação do ensaio micrográfico realizam-se as seguintes etapas:

a) Retiram-se três amostras de três volantes;

b) Faz-se o embutimento em resina de poliéster, e depois chanfram os vértices da resina;

c) Poli-se manualmente as amostras, utilizam-se lixas d’água com granulometria 80, 150, $220,320,400,600,1200,2000$, respectivamente; apoiadas sobre um vidro. A cada troca de lixa, lava-se a amostra com álcool e seca imediatamente com auxílio de um secador de jato de ar quente;

d) Poli-se as amostras em máquinas politriz com disco de pano especial, primeiramente com alumina $0,3 \mu \mathrm{m}$ e depois com alumina $0,05 \mu \mathrm{m}$. Novamente, lava-se com álcool e depois seca com jato de ar quente;

e) A primeira análise das amostras é sem ataque químico para melhor observar as formas da grafita existente;

f) Atacam-se as amostras com Nital $2 \%$ (solução de álcool etílico com $2 \%$ de ácido nítrico), lavam-se imediatamente com álcool e depois secam com jato de ar quente.

A finalidade do ataque químico é possibilitar melhor observação da matriz do ferro fundido cinzento. O Nital não ataca a ferrita nem a cementita, mas delineia os seus contornos e colore de escuro a perlita (COLPAERT, 1974).

As amostras são analisadas em um microscópio ótico, modelo Axiotech da marca Zeiss. 


\section{4 - RESULTADOS E DISCUSSÕES}

\section{1 - RESUltados DE DESGASTE DOS INSERTOS E RUGOSIDADE SUPERFICIAL DO MATERIAL USINADO}

Neste item apresenta-se uma comparação entre o desempenho das ferramentas de corte (com relação ao desgaste de flanco e à rugosidade superficial $\mathrm{Ra}$ ) variando-se o material da ferramenta e as condições de usinagem, conforme Tabela 10.

Os critérios de fim da ferramenta utilizados são:

a) Largura média do desgaste de flanco $V_{B}>0,20 \mathrm{~mm}$ ou

b) Largura máxima do desgaste de flanco $V_{B \max }>0,30 \mathrm{~mm}$ ou

c) $\mathrm{Ra}>4 \mu \mathrm{m}$ ou

d) Quebra da ferramenta ou

e) O tempo de ensaio, caso o desgaste se estabilize.

Mas em alguns casos para melhores análises dos dados após atingir um desses critérios, prolonga-se um tanto mais o ensaio.

Para fazer os gráficos de desgaste de flanco e rugosidade superficial têm-se várias alternativas para abscissa, tais como percurso de corte $\mathrm{L} c$, percurso de avanço $L f$, tempo de usinagem e números de faceamento. Optou-se utilizar o percurso de avanço $L f$, por ser mais comumente usado na industria. Portanto fazem-se os gráficos em função do percurso de avanço $\mathrm{L} f \mathrm{em} \mathrm{mm}$. Em torneamento externo $\mathrm{L} f=\mathrm{f}$.n.T, onde $\mathrm{n}$ é a rotação da peça em rpm, $\mathrm{f}$ é o avanço em mm/volta e T é o tempo em minutos (DINIZ et al., 1999) (FERRARESI, 1977). Mas no caso de torneamento de faceamento, a cada passe o percurso de avanço é a diferença entre o raio maior e o raio menor da peça. No experimento a cada faceamento o percurso de avanço L $f$ é $42 \mathrm{~mm}$. No APÊNDICE VI tem-se a formulação detalhada do percurso de corte $L c$ para o movimento espiral, uma equação de conversão de $L f$ para $L c$ e uma tabela de conversão. 
Nos gráficos de desgaste de flanco, com auxílio do programa Microsoft@ Excel, traçamse linhas de tendência do tipo polinomial com o intuito de ajudar a compreensão dos dados e verificar alguma relação entre eles, mas sem a preocupação de ajuste matemático em relação aos pontos (linha de tendência ou regressão).

Os gráficos de Rugosidade Superficial são feitos em gráficos de barras com a dispersão $\pm S / \sqrt{n}$, onde $\mathrm{S}$ é o desvio padrão da amostra e $\mathrm{n}$ é o número de dados coletados (PIMENTEL et al., 1987).

Têm-se várias análises de dados. Primeiramente para o avanço $\mathrm{f}=0,08 \mathrm{~mm} /$ volta $\mathrm{e}$ depois para $\mathrm{f}=0,10 \mathrm{~mm} /$ volta que se realiza somente com o inserto de cerâmica.

\subsection{1 - Investigação do efeito da velocidade de corte usando-se insertos de metal duro}

Nesta primeira análise de dados, apresentam-se gráficos de desgaste de flanco $V_{B}$ e de $\mathrm{Ra}$, variando-se a velocidade de corte e o sistema de refrigeração, a seco e com MQL. As condições de usinagem são: $a_{p} 0,5 \mathrm{~mm}$ e $\mathrm{f} 0,08 \mathrm{~mm} /$ volta. Na lubrificação MQL a vazão de óleo é $12 \mathrm{ml} / \mathrm{h}$ e a vazão de ar $18 \mathrm{~m}^{3} / \mathrm{h}$.

\subsubsection{1 - Análise do Desgaste de Flanco $V_{B}$}

A Figura 24 mostra a evolução do desgaste de flanco $V_{B}$ em função do percurso de avanço $L f$ no torneamento com inserto de metal duro a seco, usando-se três velocidades de corte:

- $v_{c} \mathbf{1 0 0 0} \mathrm{m} / \mathrm{min}: V_{B}$ varia pouco, permanece quase estável. Portanto interrompe-se o ensaio no $4^{\circ}$ passe de faceamento. Este ensaio utiliza o mesmo volante;

- $v_{c} 1350 \mathrm{~m} / \mathrm{min}: \mathrm{V}_{\mathrm{B}}$ aumenta até aproximadamente $\mathrm{L} f 168 \mathrm{~mm}$, permanece quase constante até $\mathrm{L} f 294 \mathrm{~mm}$, quando ocorre aumento acentuado do desgaste, ultrapassando o limite de fim de vida do inserto $V_{B}>0,20 \mathrm{~mm}$, interrompe-se o ensaio no $9^{\circ}$ passe. Neste ensaio no fim do $7^{\circ}$ passe ocorre troca de volante ( $\left.\mathrm{L} f 294 \mathrm{~mm}\right)$;

- $\quad \mathbf{v}_{\mathbf{c}} \mathbf{1 7 0 0} \mathrm{m} / \mathrm{min}$ : ocorre quebra do inserto no $5^{\circ}$ passe ( $f 210 \mathrm{~mm}$ ) (mede-se $\mathrm{V}_{\mathrm{B}} 1,625$ $\mathrm{mm})$. A partir do $3^{\circ}$ passe ( $\left.\mathrm{L} f 126 \mathrm{~mm}\right)$, realiza-se o ensaio com outro volante.

Na curva $V_{c} 1350 \mathrm{~m} / \mathrm{min}$, após um intervalo de estabilidade de $V_{B}$, ocorre aumento rápido do mesmo e chega-se ao fim da vida do inserto. Para $\mathrm{v}_{\mathrm{c}} 1700 \mathrm{~m} / \mathrm{min}$ não existe este 
intervalo de estabilidade de $V_{B}$, uma vez que esta velocidade de corte é extremamente alta para tal condição de usinagem. No torneamento com $\mathrm{v}_{\mathrm{c}} 1000 \mathrm{~m} / \mathrm{min}$ mostra-se somente $\mathrm{o}$ intervalo de estabilidade de $V_{B}$, onde provavelmente este intervalo é mais prolongado que na condição $\mathrm{v}_{\mathrm{c}} 1350 \mathrm{~m} / \mathrm{min}$.

Uma pequena variação na velocidade de corte tem uma influência bem mais significativa no desgaste de flanco $V_{B}$. Por exemplo, no caso de inserto de metal duro, no percurso de avanço $\mathrm{L} f 168 \mathrm{~mm}$, um aumento de $\mathrm{v}_{\mathrm{c}}$ de $26 \%$ (1350 para $1700 \mathrm{~m} / \mathrm{min}$ ) gera-se um aumento de $V_{B}$ de $60 \%$, e para um aumento de $v_{c}$ de apenas $35 \%(1000$ para $1350 \mathrm{~m} / \mathrm{min}), V_{B}$ aumenta $117 \%$.

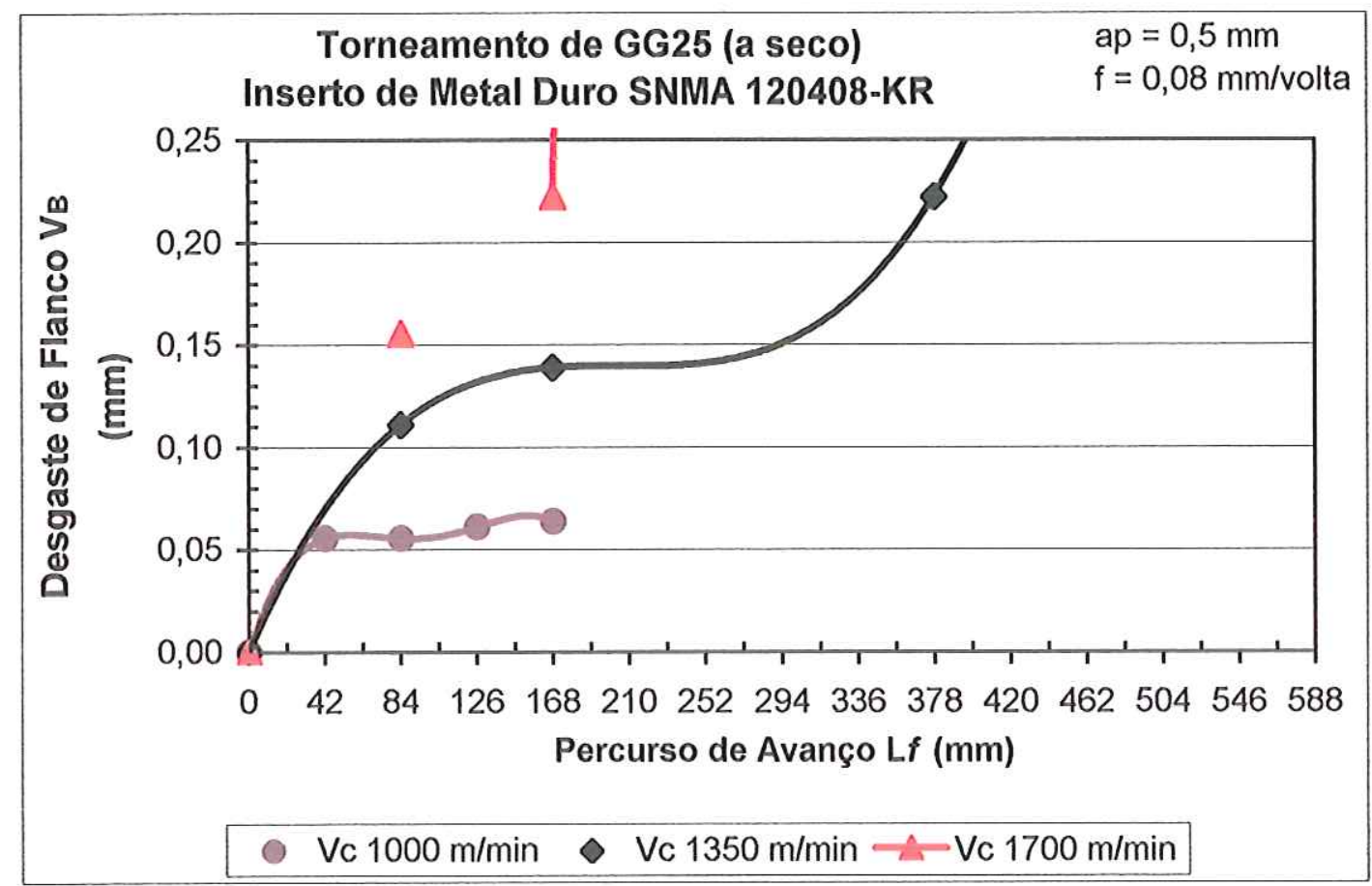

Figura 24 - Gráfico do Desgaste de Flanco $V_{B}$ no torneamento a seco de GG25 com inserto de metal duro

Após esses primeiros ensaios, realizados a seco, as condições de corte mais severas são escolhidas para o teste usando-se MQL (vazão de óleo $12 \mathrm{ml} / \mathrm{h}$ e vazão de ar $18 \mathrm{~m}^{3} / \mathrm{h}$ ).

A Figura 25 mostra a evolução do desgaste de flanco $V_{B}$ em função do percurso de avanço $\mathrm{L} f$ usando-se inserto de metal duro com MQL. Os dois maiores valores de velocidade são empregados:

- $\quad v_{c} 1350 \mathrm{~m} / \mathrm{min}$ : há um achatamento da curva em relação à curva a seco. Nos últimos cinco passes $V_{B}$ permanece constante aproximadamente em 0,125 mm. Comparando-se com a operação a seco, para o mesmo percurso de $357 \mathrm{~mm},\left(V_{B}=0,20 \mathrm{~mm}\right.$ a seco, 
Figura 24) o desgaste de flanco é aproximadamente $40 \%$ menor com MQL. Ocorre troca de volante no $6^{\circ}$ para o $7^{\circ}$ passe $(\mathrm{L} f 294 \mathrm{~mm})$;

- $\quad v_{c} 1700 \mathrm{~m} / \mathrm{min}$ : verifica-se a estabilidade de $V_{B}$ em torno de $0,205 \mathrm{~mm}$ a partir do $4^{\circ}$ passe (Lf $168 \mathrm{~mm}$ ). Como o valor de $\mathrm{V}_{\mathrm{B}}$ no $4^{\circ}$ passe é $0,203 \mathrm{~mm}$ e esta curva está próxima daquela a seco, prolonga-se o ensaio para melhores análises e verifica-se a estabilidade de $V_{B}$. Este ensaio utiliza o mesmo volante.

Prolonga-se a vida do inserto, no mínimo, $56 \%$ em relação ao torneamento a seco. Nestas curvas não aparece o estágio de aumento rápido de $\mathrm{V}_{\mathrm{B}}$ e prolonga-se a estabilidade do mesmo. Nota-se a semelhança das duas curvas, sendo que com o aumento da velocidade de corte ocorre aumento do desgaste de flanco $V_{B}$, para um aumento de $\mathrm{v}_{\mathrm{c}}$ de $26 \%$ (1350 para $1700 \mathrm{~m} / \mathrm{min}$ ), o aumento de $\mathrm{V}_{B}$ é bem mais significativo (no mínimo $74 \%$ ). Mas com o aumento do percurso de avanço $L f$, a diferença de $V_{B}$ entre $v_{c} 1700 \mathrm{~m} / \mathrm{min}$ e $v_{c} 1350 \mathrm{~m} / \mathrm{min}$ tende a diminuir no intervalo de ensaio.

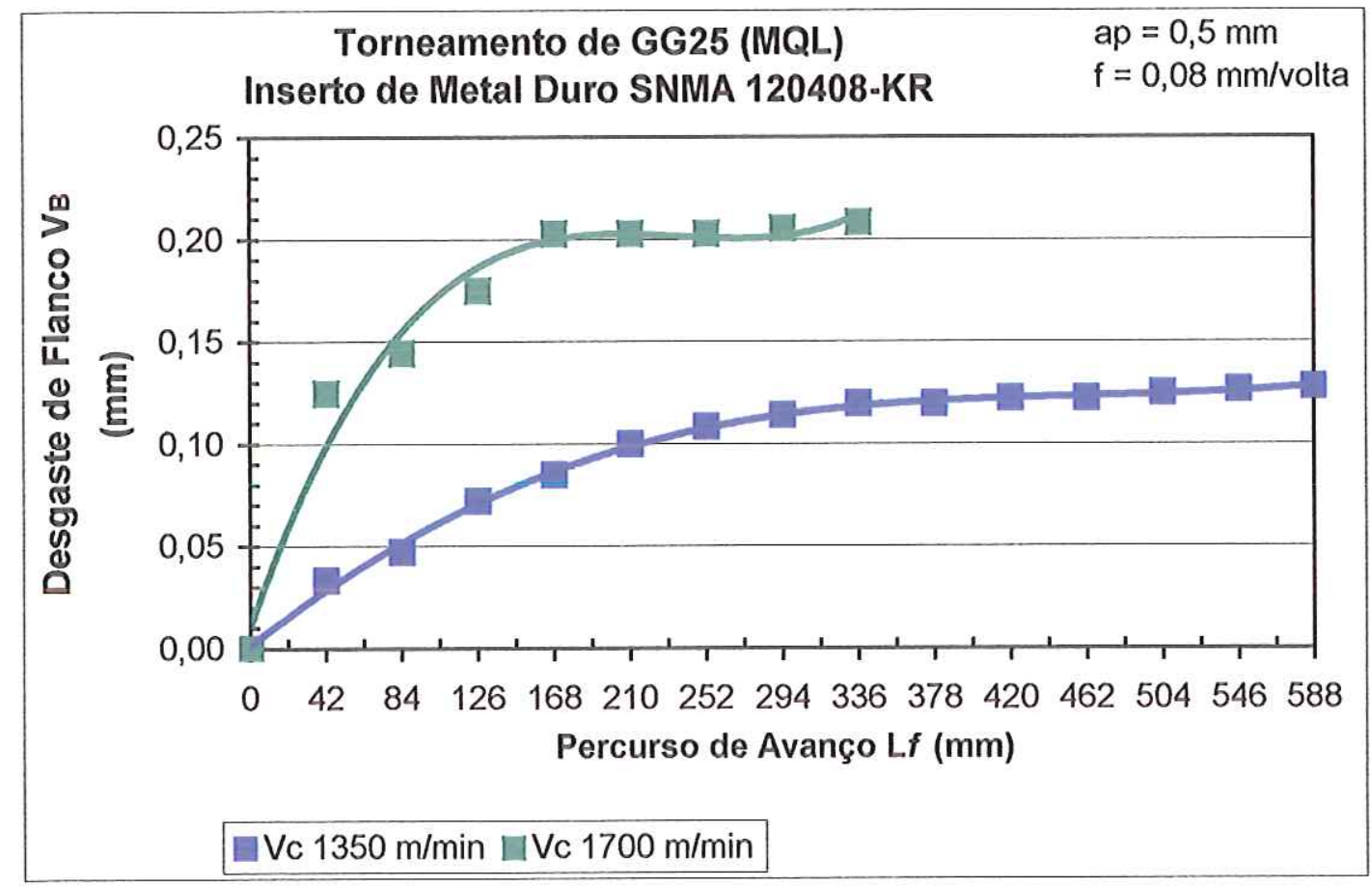

Figura 25 - Gráfico do Desgaste de Flanco $V_{B}$ no torneamento com MQL (vazão de óleo 12 $\mathrm{ml} / \mathrm{h}$ e vazão de ar $18 \mathrm{~m}^{3} / \mathrm{h}$ ) de GG25 com inserto de metal duro

Para comparação direta entre os resultados de desgaste obtidos com operação a seco e com MQL, no gráfico da Figura 26 tem-se a razão entre $V_{B}$ do torneamento a seco e com MQL para $v_{c} 1700 \mathrm{~m} / \mathrm{min}$. Observa-se que a proporção entre o desgaste de flanco $V_{B}$ para 
operação a seco e com MQL permanece constante até Lf $168 \mathrm{~mm}$, a partir de então cresce rapidamente devido ao rápido aumento do desgaste $\mathrm{V}_{\mathrm{B}}$ a seco.

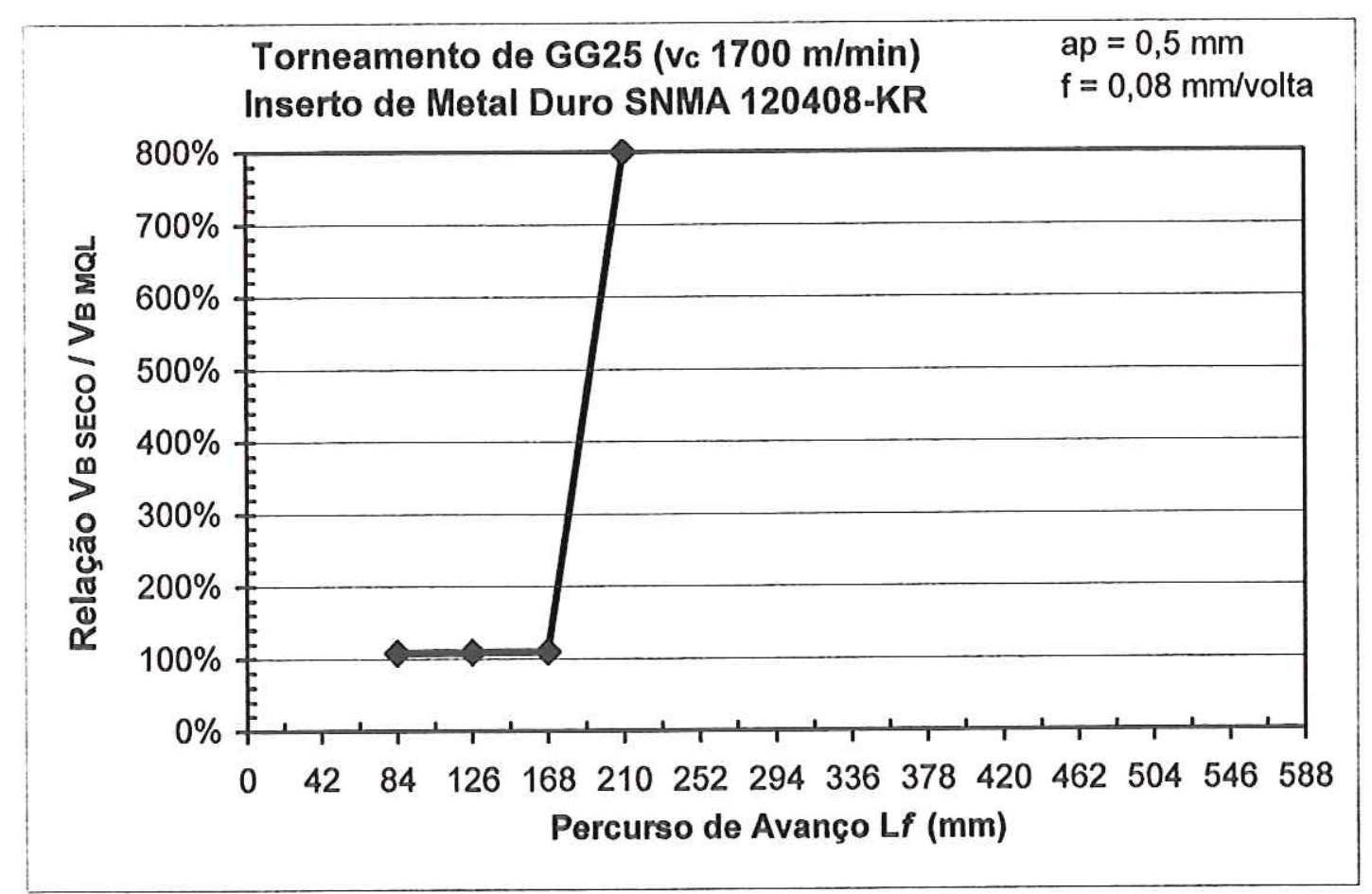

Figura 26 - Razão entre $\mathrm{V}_{\mathrm{B}}$ do torneamento a seco e com MQL (vazão de óleo $12 \mathrm{ml} / \mathrm{h}$ e vazão de $\operatorname{ar} 18 \mathrm{~m}^{3} / \mathrm{h}$ ) para $\mathrm{v}_{\mathrm{c}} 1700 \mathrm{~m} / \mathrm{min}$ em função do percurso de avanço $\mathrm{L} f$

Na Figura 27 mostram-se todas as curvas já discutidas, reunidas em um só gráfico para uma visualização geral de todos os ensaios realizados para estudo da influência da velocidade de corte no desgaste. Observa-se que há, uma estabilidade de $V_{B}$ no ensaio a seco com $\mathrm{v}_{\mathrm{c}} 1000 \mathrm{~m} / \mathrm{min}$ e em todos aqueles se usando MQL. 


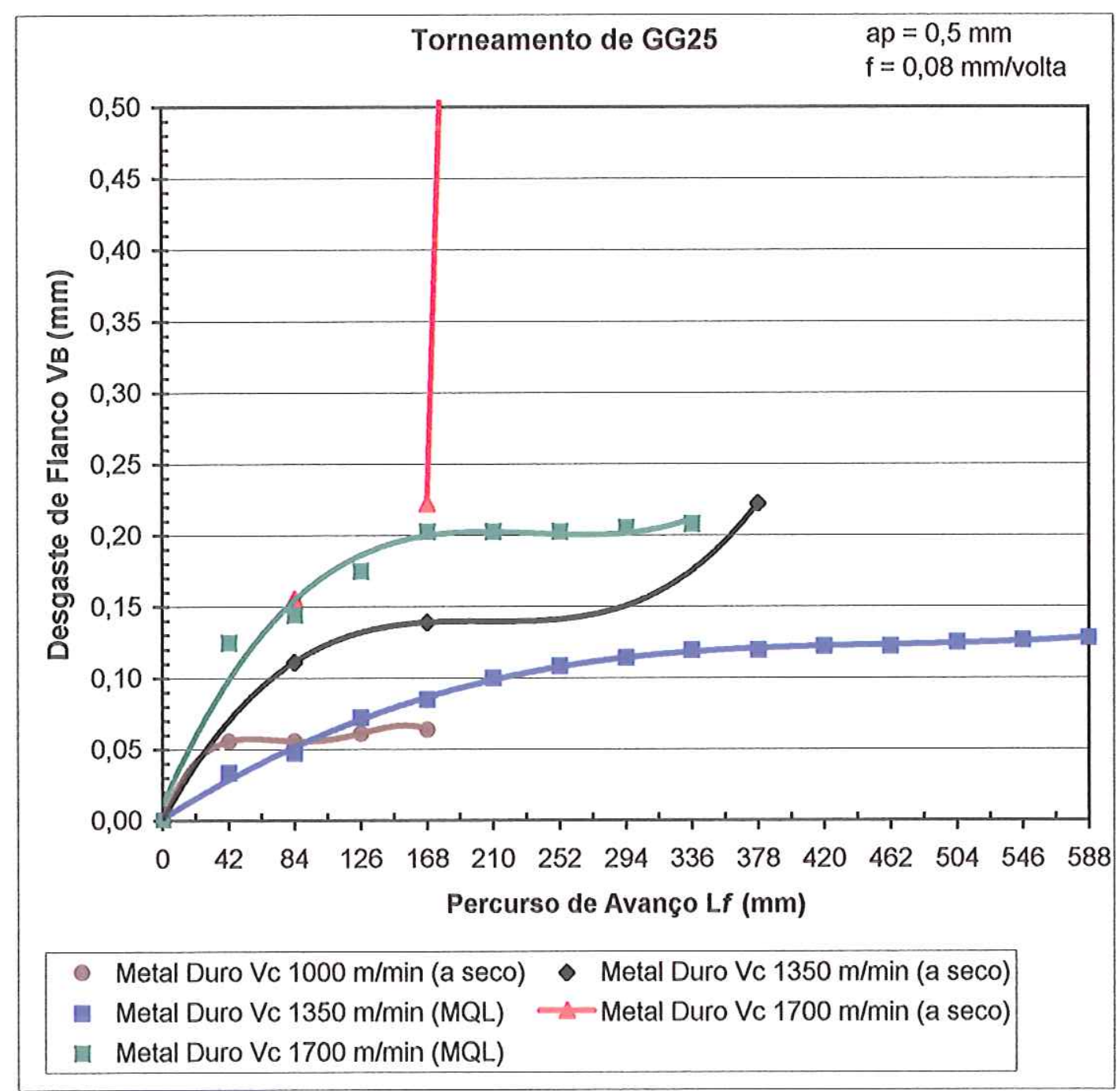

Figura 27 - Gráfico do Desgaste de Flanco $V_{B}$ no torneamento a seco e com MQL (vazão de óleo $12 \mathrm{ml} / \mathrm{h}$ e vazão de ar $18 \mathrm{~m}^{3} / \mathrm{h}$ ) de GG25 com inserto de metal duro

\subsubsection{2 - Relação entre Desgaste de Flanco Médio $V_{B}$ e Desgaste de Flanco Máximo $V_{\text {Bmáx }}$}

Neste item analisa-se a relação entre o desgaste de flanco médio $V_{B}$ e o desgaste de flanco máximo $\mathrm{V}_{\mathrm{Bmax}} \mathrm{em}$ função do percurso de avanço $\mathrm{L} f$. Os gráficos das Figura 28, Figura 29 e Figura 30 trazem os valores de $V_{B}$ médio já mostrados anteriormente acrescidos dos dados de $V_{B \max }$ para fins de comparação.

Nos gráficos de torneamento a seco com metal duro, $v_{c} 1000 \mathrm{~m} / \mathrm{min}$ (Figura 28) e $\mathrm{v}_{\mathrm{c}}$ $1350 \mathrm{~m} / \mathrm{min}$ (Figura 29) observa-se uma tendência de aumento relativo entre $V_{B \max }$ e $V_{B}$ conforme aumenta o percurso de avanço $\mathrm{L} f$. 


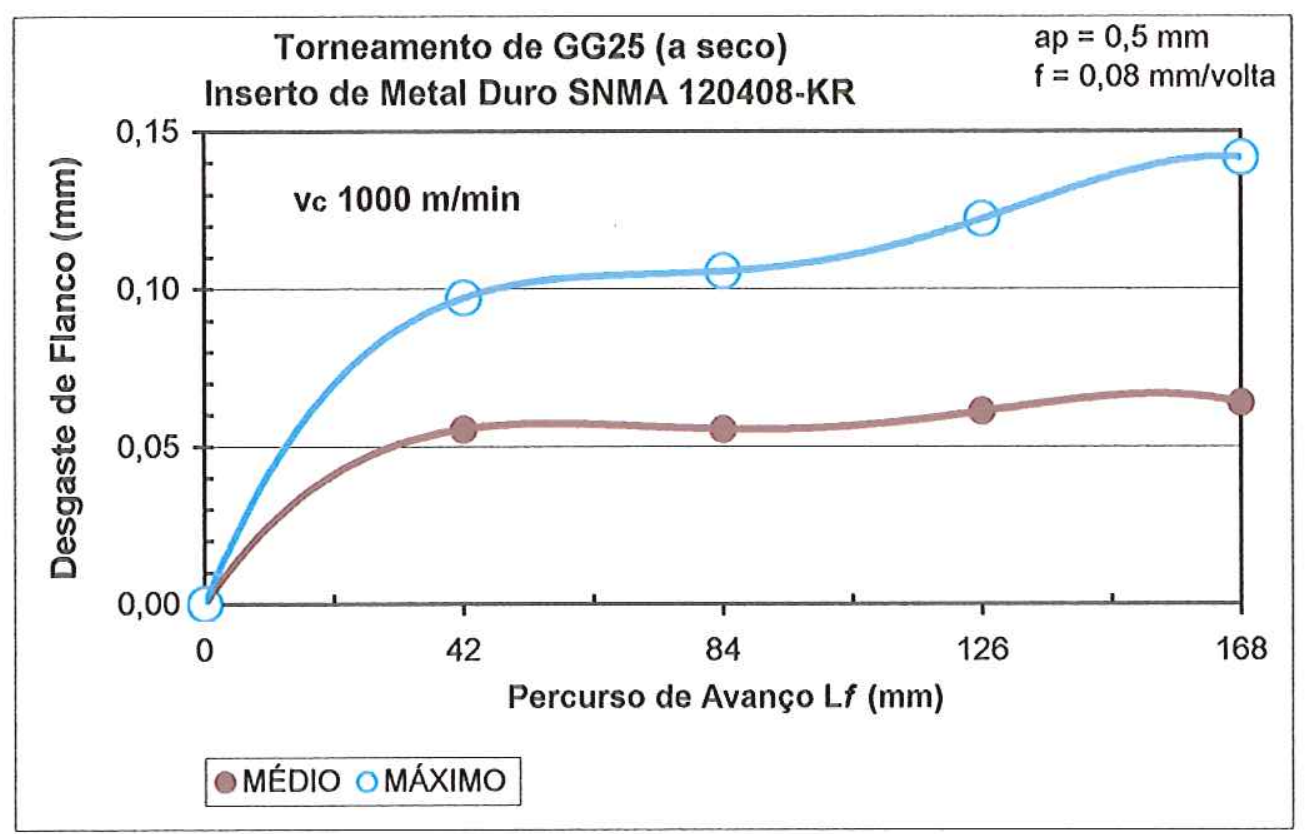

Figura 28 - Gráfico comparativo do Desgaste de Flanco $V_{B}$ e $V_{B \max }$ no torneamento de GG25 com inserto de metal duro com $\mathrm{v}_{\mathrm{c}} 1000 \mathrm{~m} / \mathrm{min}$ (a seco)

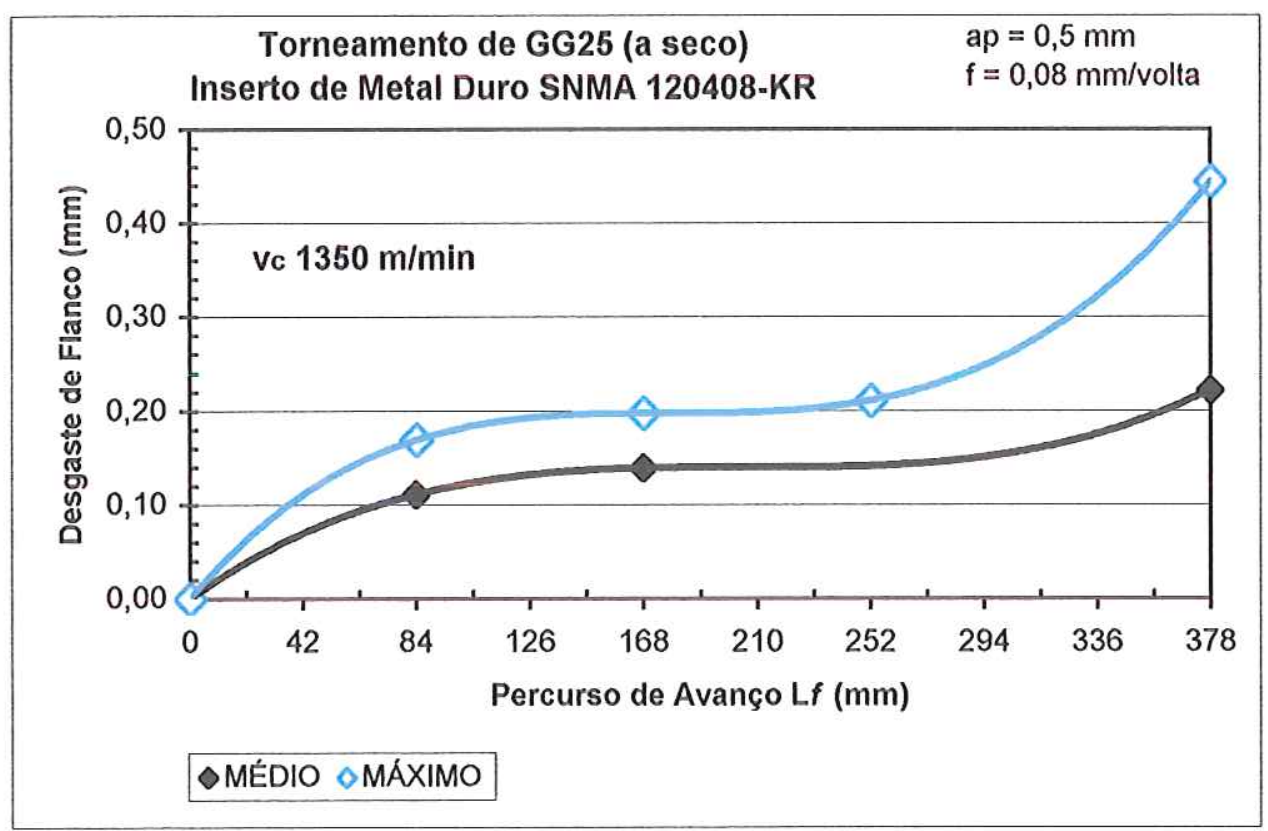

Figura 29 - Gráfico comparativo do Desgaste de Flanco $V_{B}$ e $V_{B \max }$ no torneamento de GG25 com inserto de metal duro com $\mathrm{v}_{\mathrm{c}} 1350 \mathrm{~m} / \mathrm{min}$ (a seco)

Já no gráfico do torneamento com MQL usando-se metal duro com $\mathrm{v}_{\mathrm{c}} 1700 \mathrm{~m} / \mathrm{min}$ da Figura 30 não se observa a tendência anterior e a relação entre o desgaste de flanco $V_{B \max } e$ 
$\mathrm{V}_{\mathrm{B}}$ tende diminuir até $\mathrm{L} f 168 \mathrm{~mm}$, sendo que a partir deste momento permanece uma relação constante (aproximadamente 28\%) ao longo dos ensaios.

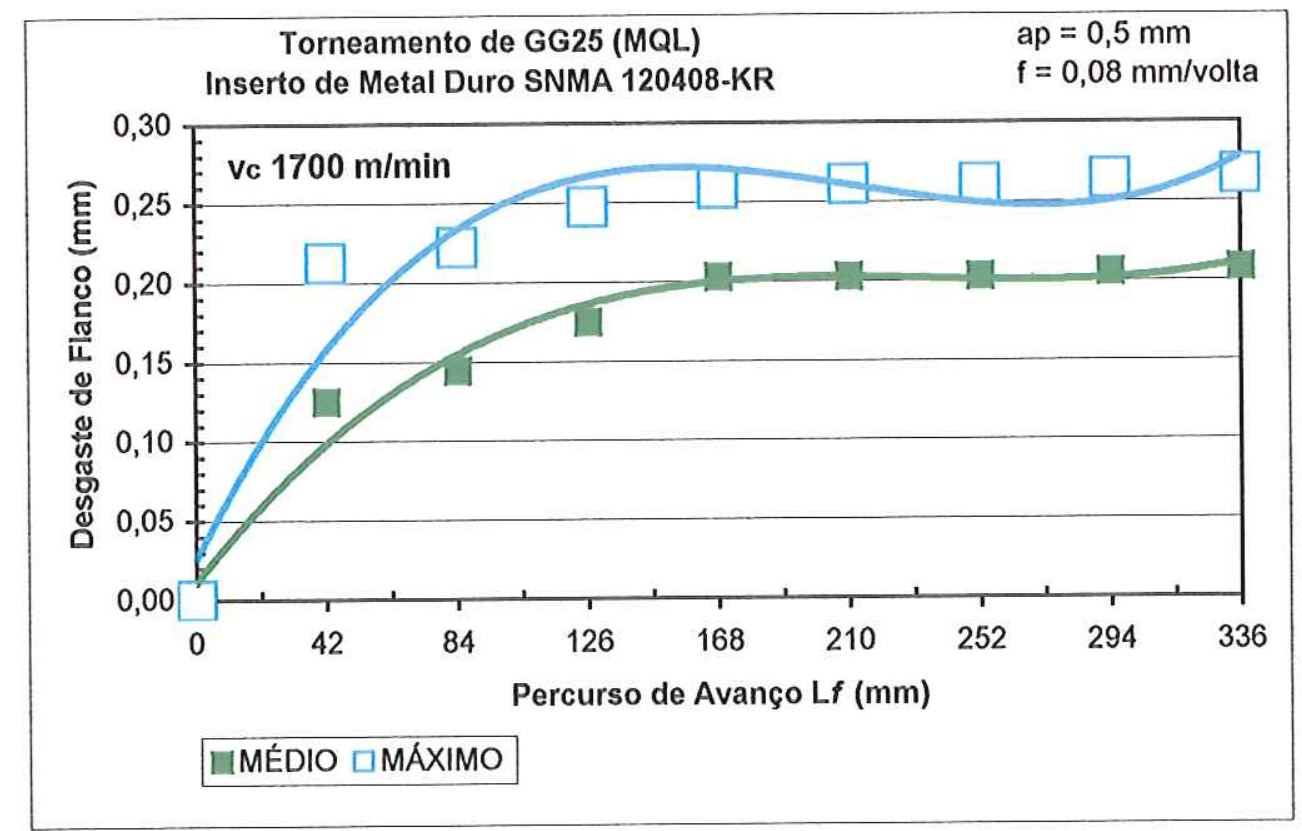

Figura 30 - Gráfico comparativo do Desgaste de Flanco $V_{B}$ e $V_{B \max }$ no torneamento de GG25 com inserto de metal duro com $v_{\mathrm{c}} 1700 \mathrm{~m} / \mathrm{min}$ (com MQL: vazão de óleo $12 \mathrm{ml} / \mathrm{h} \mathrm{e}$ vazão de ar $18 \mathrm{~m}^{3} / \mathrm{h}$ )

Nas condições de torneamento com metal duro $\left(v_{c} 1350 \mathrm{~m} / \mathrm{min}\right.$ - MQL e $v_{c} 1700 \mathrm{~m} / \mathrm{min}$ - a seco) as diferenças entre o desgaste de flanco $V_{B \max }$ e $V_{B}$ são pequenas.

\subsubsection{3 - Análise da Rugosidade Superficial Ra}

A Figura 31 mostra a evolução da rugosidade superficial Ra em função do percurso de avanço $\mathrm{L} f$ com metal duro a seco usando-se três valores de velocidade:

- $\quad \mathbf{v}_{\mathbf{c}} \mathbf{1 0 0 0} \mathrm{m} / \mathbf{m i n}$ : a rugosidade superficial permanece quase constante com o aumento do percurso de avanço. Os valores medidos da rugosidade superficial variam no intervalo $1,03 \leq \mathrm{Ra} \leq 1,36 \mu \mathrm{m}$

- $v_{c} 1350 \mathrm{~m} / \mathbf{m i n}$ : na condição de fim de vida do inserto verifica-se que os valores de rugosidade aumentam do diâmetro maior para o menor, provavelmente porque o desgaste se acentua nesse último passe. Os valores medidos da rugosidade superficial variam no intervalo $1,07 \leq \mathrm{Ra} \leq 1,98 \mu \mathrm{m}$; 
- $\quad v_{c} 1700 \mathrm{~m} / \mathrm{min}$ : verifica-se que é exatamente no último passe $\left(5^{\circ}\right)$ onde ocorre a quebra da ferramenta, mais precisamente no final do faceamento, onde se mede $\mathrm{Ra}=3,66 \mu \mathrm{m}$. Nota-se aumento da rugosidade superficial com o aumento do desgaste de flanco em função de $\mathrm{L} f$. Esta velocidade de corte é extremamente alta para estas condições, onde a menor rugosidade superficial Ra medida é $1,60 \mu \mathrm{m}$.

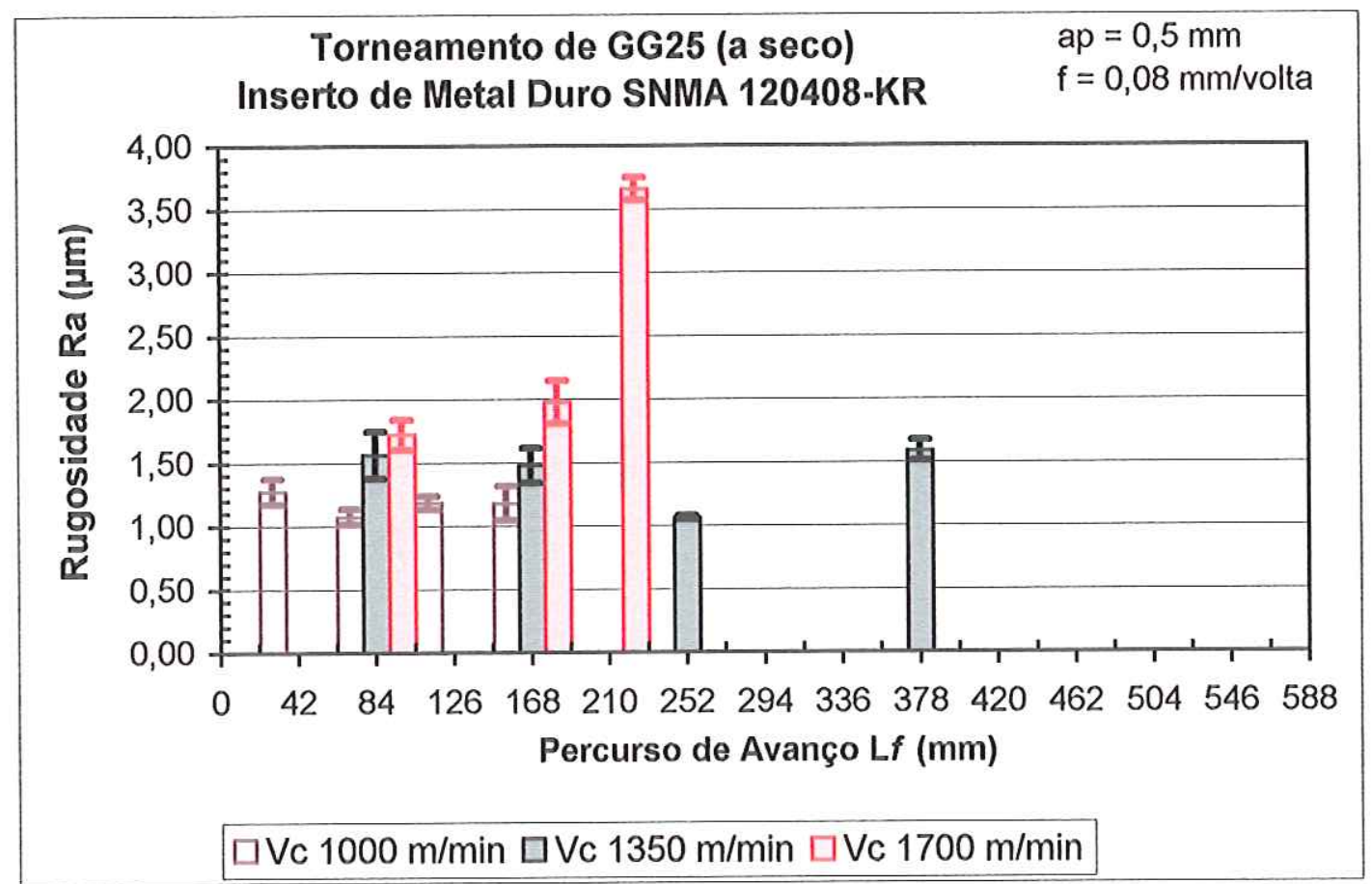

Figura 31 - Gráfico da Rugosidade Superfícial Ra no torneamento a seco de GG25 com inserto de metal duro

A Figura 32 mostra a evolução da rugosidade superficial Ra em função do percurso de avanço $\mathrm{L} f$ com inserto de metal duro e MQL usando-se as duas maiores velocidades:

- $\quad v_{c} 1350$ m/min: a dispersão dos valores de Ra é elevada. Os valores medidos da rugosidade superficial variam no intervalo $0,86 \leq \mathrm{Ra} \leq 1,46 \mu \mathrm{m}$;

- $\quad \mathbf{v}_{\mathbf{c}} \mathbf{1 7 0 0} \mathrm{m} / \mathrm{min}$ : aparentemente nota-se relação da rugosidade superficial com o desgaste de flanco em função de $\mathrm{L} f$. Os valores medidos da rugosidade superficial variam no intervalo $1,04 \leq \mathrm{Ra} \leq 1,69 \mu \mathrm{m}$. 


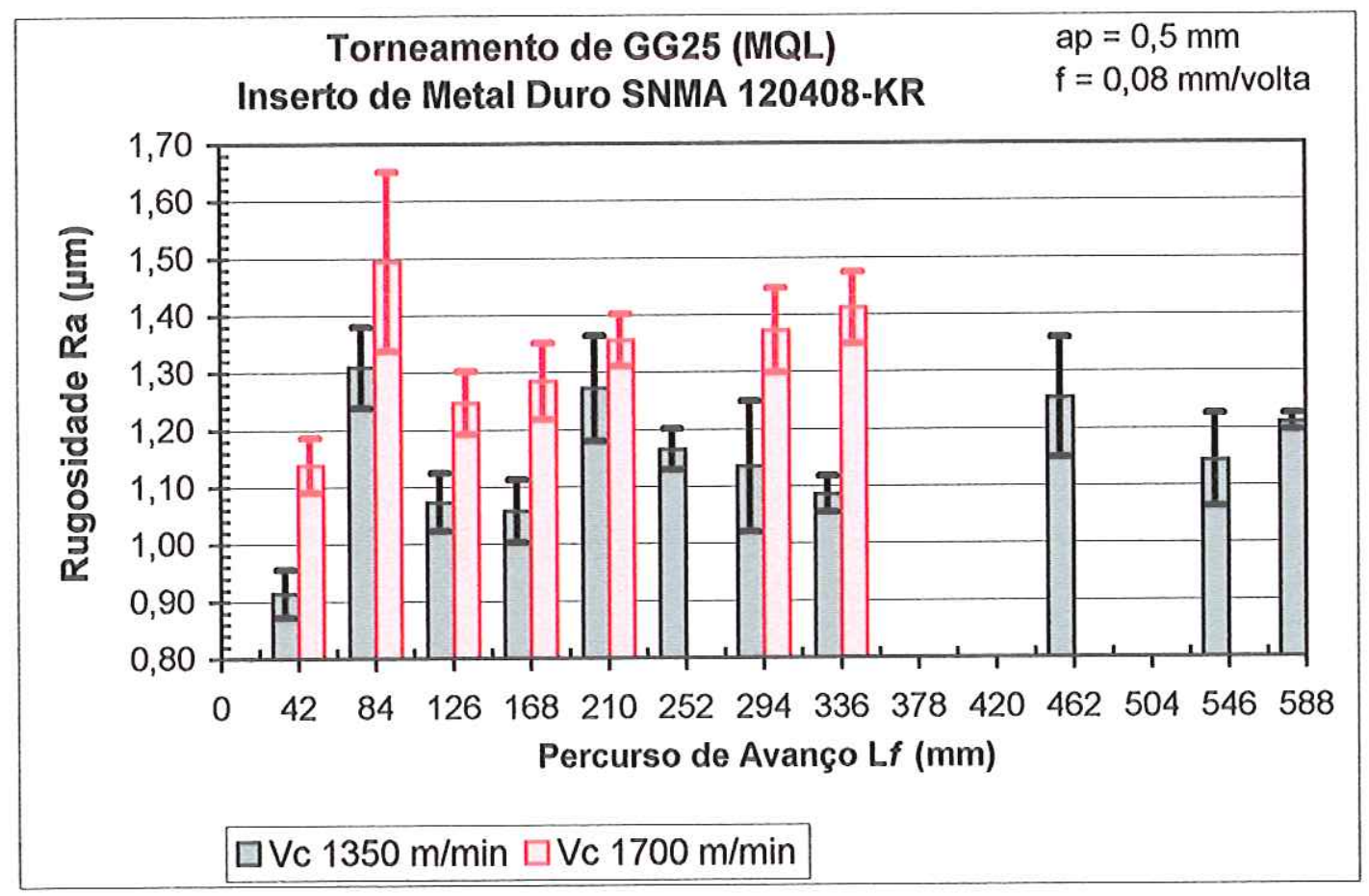

Figura 32 - Gráfico da Rugosidade Superficial Ra no torneamento com MQL (vazão de óleo $12 \mathrm{ml} / \mathrm{h}$ e vazão de ar $18 \mathrm{~m}^{3} / \mathrm{h}$ ) de GG25 com inserto de metal duro

\subsubsection{4 - Curva de Desgaste do inserto de metal duro em função da velocidade de corte}

Há poucos valores de velocidade de corte testados, devido ao tempo de ensaios e disponibilidade de ferramentas, portanto, as curvas de vida são mostradas para a condição $L f$ $168 \mathrm{~mm}$. Na Figura 33 verifica-se o crescimento do desgaste de flanco $V_{B}$ ambas as condições de refrigeração. No torneamento com MQL o desgaste de flanco $\mathrm{V}_{\mathrm{B}}$ é sempre inferior àquela do torneamento a seco. Para a velocidade de corte de $1700 \mathrm{~m} / \mathrm{min}$ tem-se quase o mesmo valor de $V_{B}$ para ambas condições de refrigeração, mas conforme observa-se na curva da Figura 27, o desgaste de flanco para o torneamento com MQL permanece constante até $\mathrm{L} f 336 \mathrm{~mm}$. E, no torneamento a seco, no próximo passe ocorre quebra do inserto de metal duro. Portanto deve-se analisar cuidadosamente as curvas de desgaste. 


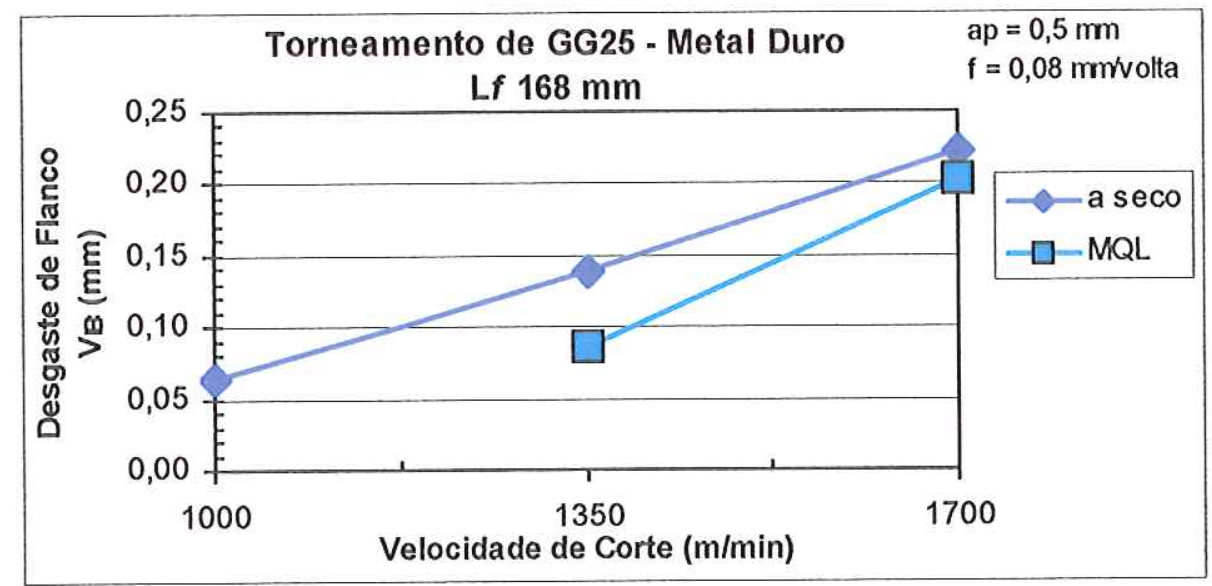

Figura 33 - Curva de vida do inserto de metal duro em função do desgaste de flanco $V_{B}$ para L $f 168 \mathrm{~mm}$ (MQL: vazão de óleo $12 \mathrm{ml} / \mathrm{h}$ e vazão de ar $18 \mathrm{~m}^{3} / \mathrm{h}$ )

A Figura 34 mostra a variação da rugosidade superficial Ra em função da velocidade de corte. Observa-se um aumento de Ra com $v_{c}$ para o torneamento a seco e com MQL, mas nesse último os valores são cerca de 70 a $80 \%$ menores.

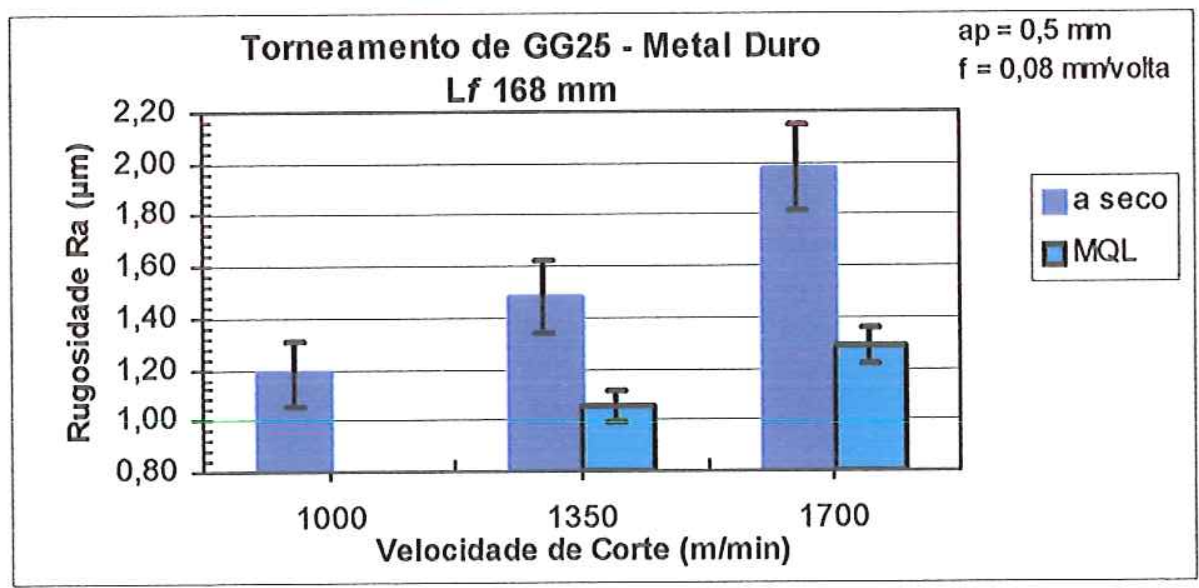

Figura 34 - Curva de vida do inserto de metal duro em função da rugosidade superficial Ra para L $f 168 \mathrm{~mm}$ (MQL: vazão de óleo $12 \mathrm{ml} / \mathrm{h}$ e vazão de ar $18 \mathrm{~m}^{3} / \mathrm{h}$ )

\subsection{2 - Investigação do efeito do avanço f no desgaste de insertos de cerâmica}




\subsubsection{1 - Análise do Desgaste de Flanco $V_{B}$}

Com a experiência adquirida nos ensaios com metal duro, decide-se realizar ensaios com a máxima velocidade de corte usando-se insertos de cerâmica para verificar a influência do avanço. Nesta análise, tem-se o torneamento de GG25 com velocidade de corte $1700 \mathrm{~m} / \mathrm{min}$, com avanços de 0,08 e $0,10 \mathrm{~mm} /$ volta e corte a seco. Na Figura 35 verifica-se que para um avanço menor, o desgaste de flanco é maior. Provavelmente deve-se ao maior tempo de contato do inserto com a peça que recebe o calor gerado no processo de corte (ver Tabela 15 - Tabela de conversão L $f$ para L $c$ no APÊNDICE VI). As duas curvas, no final dos ensaios, mostram uma tendência de aumento rápido de desgaste de flanco. O último dado da curva com avanço $0,10 \mathrm{~mm} /$ volta é $\mathrm{V}_{\mathrm{B}}=0,278 \mathrm{~mm}$ para $\mathrm{L} f=1428 \mathrm{~mm}$.

Para a curva com avanço $0,08 \mathrm{~mm} /$ volta, pode-se observar que com $\mathrm{L} f$ aproximado de $525 \mathrm{~mm}$, o inserto chega ao fim de vida $\left(\mathrm{V}_{\mathrm{B}}>0,20 \mathrm{~mm}\right)$. Pode-se generalizar que no torneamento de ferro fundido cinzento a seco existe uma curva de tendência semelhante para alguns tipos de materiais para inserto.

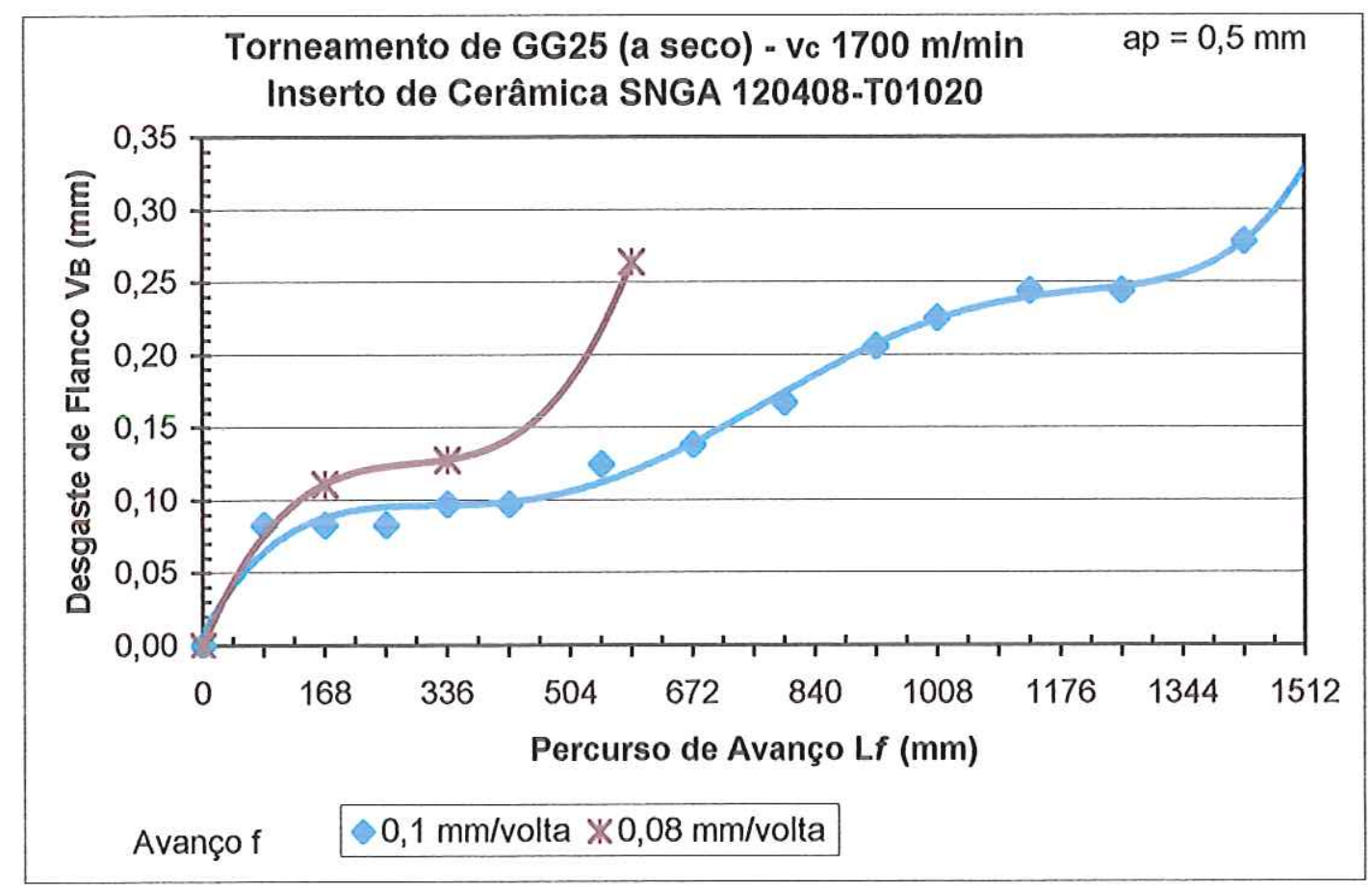

Figura 35 - Gráfico do Desgaste de Flanco $V_{B}$ no torneamento de GG25 com inserto de cerâmica com velocidade de corte $1700 \mathrm{~m} / \mathrm{min}$ para diferentes avanços (a seco) 


\subsubsection{2 - Análise da Rugosidade Superficial Ra}

Na Figura 36, tem-se a rugosidade Ra para os dois valores de avanço. Verifica-se que, apesar do desgaste $V_{B}$ ser maior para $\mathrm{f} 0,08 \mathrm{~mm} /$ volta, na última medição Ra é bem inferior.

Os valores medidos da rugosidade superficial variam no intervalo:

- $0,08 \mathrm{~mm} /$ volta: $1,74 \leq \mathrm{Ra} \leq 2,57 \mu \mathrm{m}$;

- $0,10 \mathrm{~mm} /$ volta: $0,95 \leq \mathrm{Ra} \leq 3,90 \mu \mathrm{m}$.

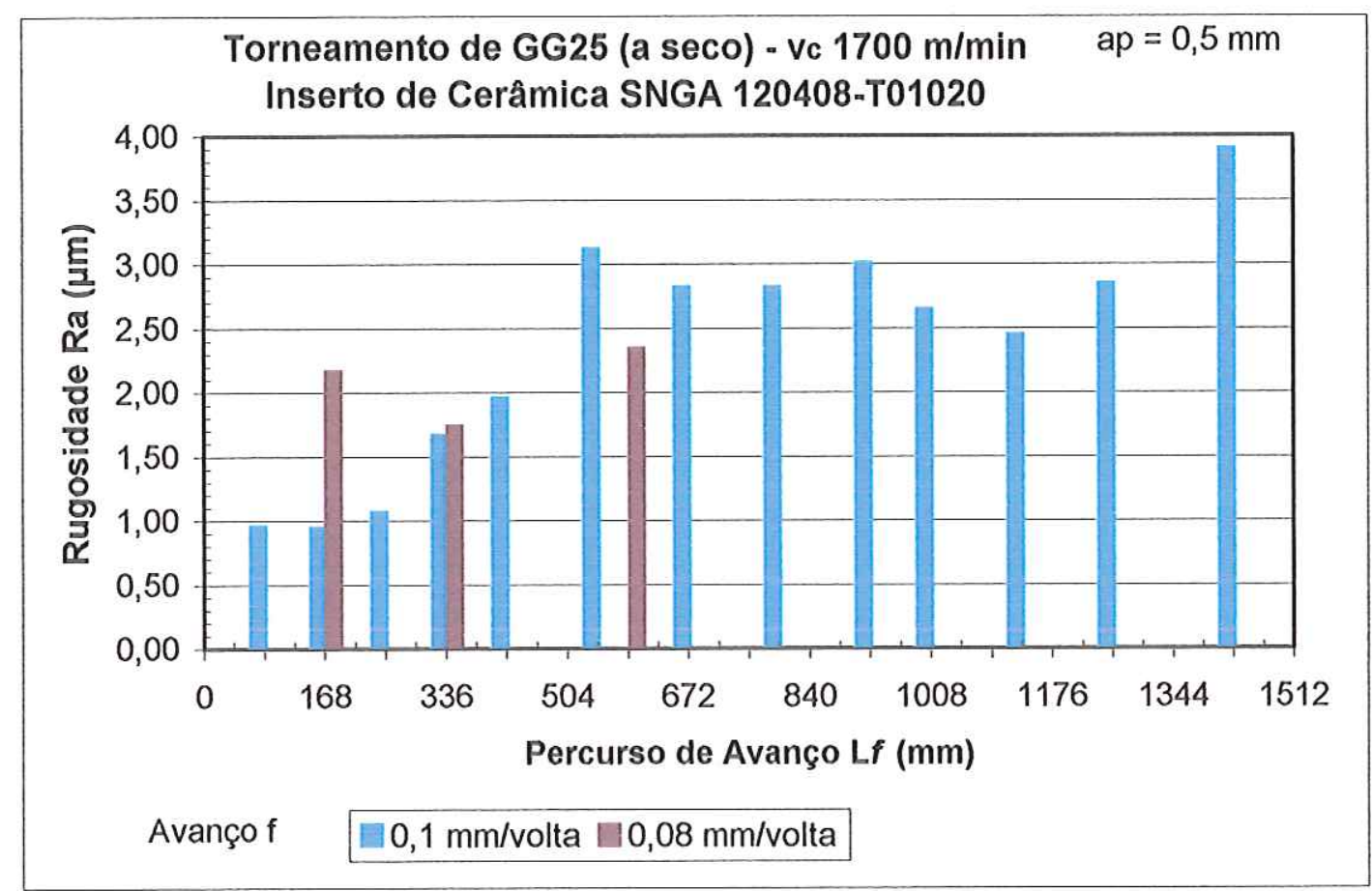

Figura 36 - Gráfico da Rugosidade Superficial Ra no torneamento de GG25 com inserto de cerâmica com velocidade de corte $1700 \mathrm{~m} / \mathrm{min}$ para diferentes avanços (a seco)

\subsection{3 - Investigação do efeito da vazão de óleo e de ar na lubrificação MQL}

Como os ensaios com MQL demonstram um melhor desempenho das ferramentas usando-se MQL, decide-se também investigar se há uma melhoria ainda maior variando-se as vazões de ar e óleo no sistema. Nesta série de ensaios, o torneamento realiza-se com inserto de cerâmica variando-se a vazão de ar entre 9 e $18 \mathrm{~m}^{3} / \mathrm{h}$ e a vazão de óleo lubrificante entre 10 e $20 \mathrm{ml} / \mathrm{h}$. As condições de usinagem são: $a_{p}=0,5 \mathrm{~mm}$ e $\mathrm{f}=0,10 \mathrm{~mm} / \mathrm{volta}$. 


\subsubsection{1 - Análise do Desgaste de Flanco $V_{B}$}

Na Figura 37 mostra-se o gráfico de desgaste em função do percurso de avanço.

Para uma vazão de óleo baixa, de $10 \mathrm{ml} / \mathrm{h}$, mesmo dobrando-se a vazão de ar não há grande diminuição no desgaste $\mathrm{V}_{\mathrm{B}}$. Isso pode ser constatado examinando-se as curvas 10/9 e 10/18 (vazão de óleo/vazão de ar) na Figura 37. Comparando-se essas curvas com a Figura 35 , onde mostra-se a curva para as mesmas condições de corte, porém a seco, nota-se que o desgaste é da mesma ordem.

Para uma vazão de óleo maior, de $20 \mathrm{ml} / \mathrm{h}$, há uma diminuição no desgaste $\mathrm{V}_{\mathrm{B}}$. Isso pode ser constatado examinando-se as curvas 20/9 e 20/18 (vazão de óleo/vazão de ar) na Figura 37. Quando há a combinação das duas maiores vazões encontra-se a melhor condição de desgaste de flanco. Como as temperaturas envolvidas na operação são aparentemente altas, acredita-se que o efeito de refrigeração seja acentuado quando se utilizam as maiores vazões de ambos os fluidos. Maiores valores de vazão de ar não são possíveis, devido a limitações no compressor utilizado. Maiores valores de vazão de óleo não são utilizados por perder-se o efeito de névoa.

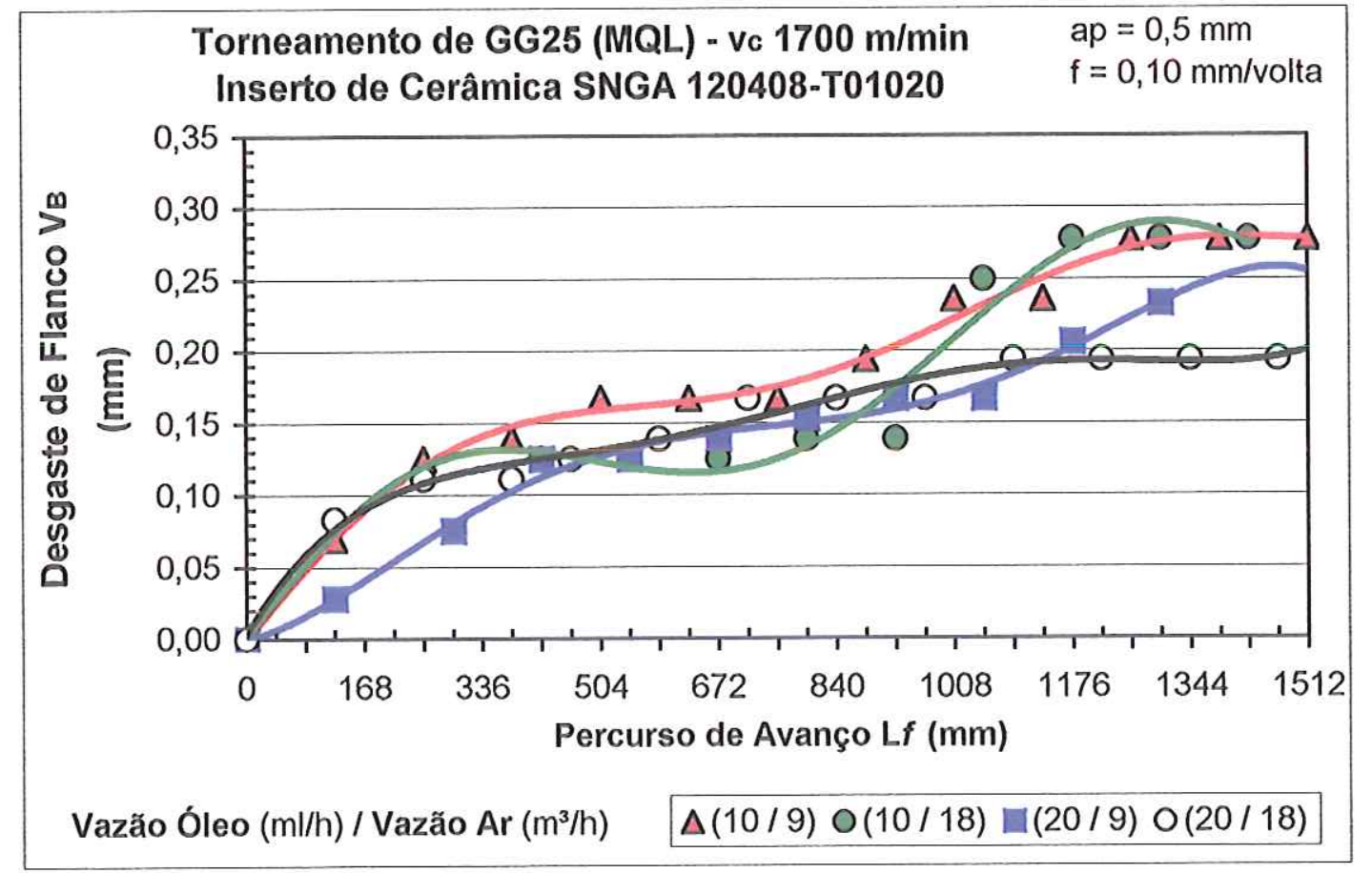

Figura 37 - Gráfico da influência da vazão de óleo e de ar no Desgaste de Flanco $V_{B}$ no torneamento com MQL de GG25 com inserto de cerâmica

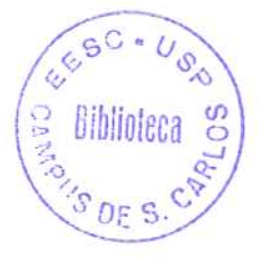




\subsubsection{2 - Análise da Rugosidade Superficial Ra}

Na Figura 38 mostra-se o gráfico de Ra para as condições do sistema MQL. Verifica-se que a lubrificação MQL melhora a qualidade superficial da peça usinada. Sendo que a superficie usinada com as maiores vazões, em geral, mantém os menores valores de rugosidade superficial Ra ao longo da vida.

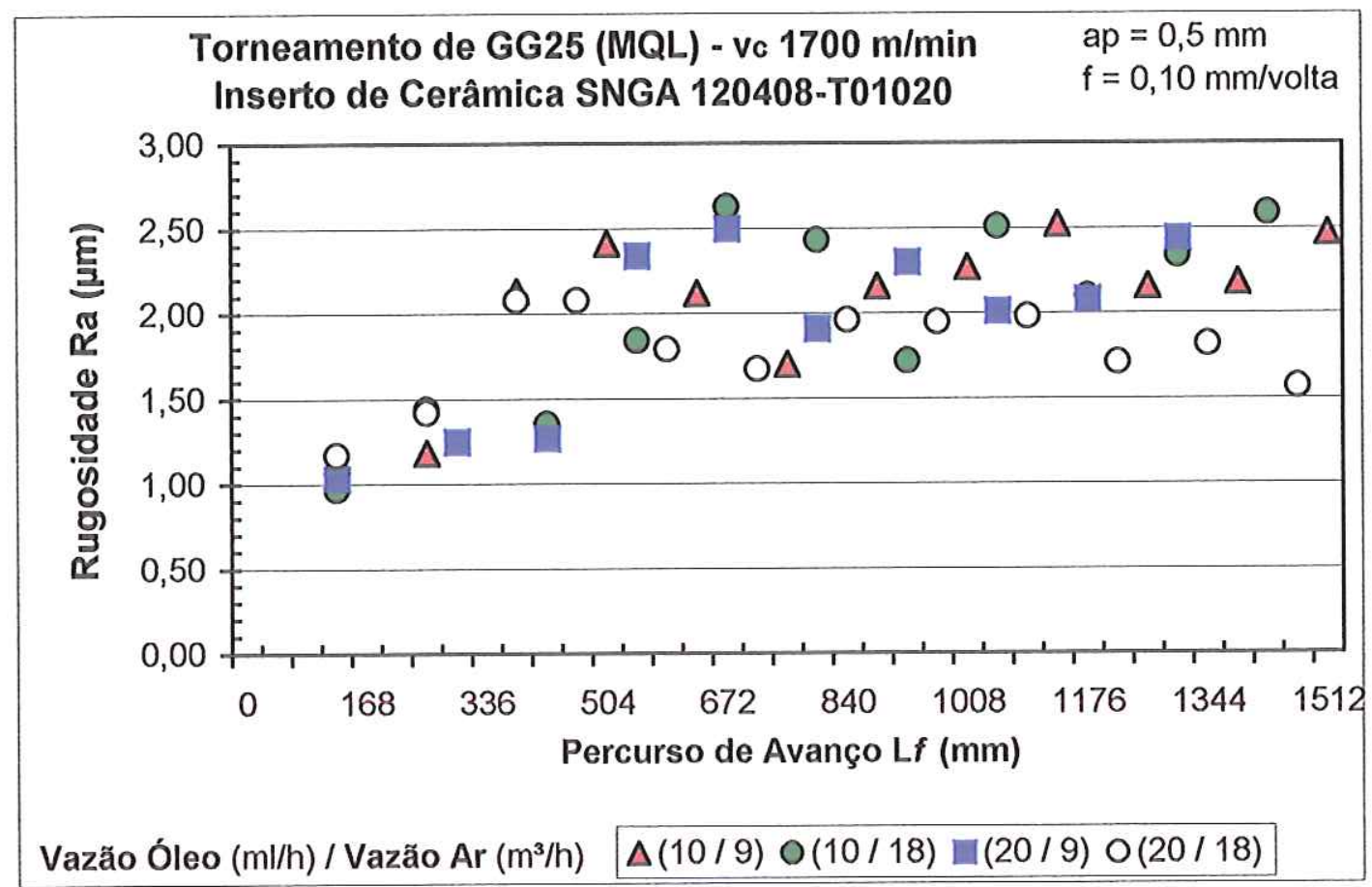

Figura 38 - Gráfico da influência da vazão de óleo e de ar na Rugosidade Superficial no torneamento com MQL de GG25 com inserto de cerâmica

\subsection{4 - Resumo dos resultados de desgaste de flanco}

As curvas de torneamento a seco caracterizam pelo rápido crescimento de desgaste de flanco $V_{B}$ após um período de estabilidade do mesmo.

Para o torneamento com inserto de metal duro usando-se MQL (vazão de óleo $12 \mathrm{ml} / \mathrm{h} \mathrm{e}$ vazão de ar $18 \mathrm{~m}^{3} / \mathrm{h}$ ), verifica-se que o desgaste de flanco diminui sensivelmente.

No torneamento com metal duro usando-se MQL nota-se que com o aumento da velocidade de corte ocorre aumento do desgaste de flanco $V_{B}$. Para um aumento de $v_{c}$ de $26 \%$ (1350 para $1700 \mathrm{~m} / \mathrm{min}$ ) na velocidade, há o aumento de $\mathrm{V}_{B}$ de $74 \%$.

No caso do torneamento com cerâmica, verifica-se uma diminuição do desgaste aumentando-se os valores de vazão de óleo e ar. 
Um aumento do avanço, de 0,08 para $0,10 \mathrm{~mm} /$ volta, possibilita diminuição do desgaste.

Em geral, a cerâmica tem desempenho superior ao metal duro com cobertura em relação ao desgaste de flanco.

Através dos dados, verifica-se que o torneamento com alta velocidade de ferro fundido cinzento é mais vantajoso com lubrificação MQL tanto para metal duro quanto para cerâmicas.

\subsection{5 - Resumo dos resultados de rugosidade superficial Ra}

Nos gráficos de Ra em função de $\mathrm{L} f$, nota-se muita dispersão dos valores o que pode ser também devido à presença de grafita na estrutura da matriz do ferro fundido cinzento, ou vibração durante os ensaios.

Verifica-se que Ra aumenta com o aumento da velocidade de corte. Não se verifica uma relação direta de Ra com o avanço f, embora somente dois valores tenham sido testados.

No torneamento com inserto de metal duro e MQL verifica-se que este reduz os valores de rugosidade superficial Ra.

No caso do inserto de cerâmica, a rugosidade superficial seınpre diminui com MQL, independentemente da relação óleo/ar.

Usando-se MQL, a maior vazão de óleo sempre melhora a rugosidade superficial, mas dependendo da relação óleo/ar, pode melhorar ainda mais a qualidade superficial.

\section{2 - ANÁLISE DE DESGASTE DOS INSERTOS}

Conforme item 4.1, pode-se notar graficamente que o desgaste dos insertos são fortemente influenciados pela velocidade de corte. A identificação dos mecanismos e tipos de desgaste que atuam sobre os insertos é efetuada com base em fotografias feitas em um microscópio eletrônico de varredura, revelando detalhes dos insertos desgastados.

A apresentação das fotografias realiza-se de acordo com a velocidade de corte.

\subsection{1 - Metal Duro (velocidade de corte $1000 \mathrm{~m} / \mathrm{min}$ e avanço 0,08 $\mathrm{mm} /$ volta)}

A Figura 39 mostra uma visão geral da aresta de corte desgastada do inserto de metal duro com cobertura no torneamento a seco de ferro fundido cinzento GG25 com velocidade 
de corte $1000 \mathrm{~m} / \mathrm{min}$. Observa-se pouco desgaste de flanco ao longo da aresta de corte do inserto (evidenciado no gráfico da Figura 24). Nota-se desgaste de entalhe e não há indícios de desgaste de cratera sobre a superfície de saída.

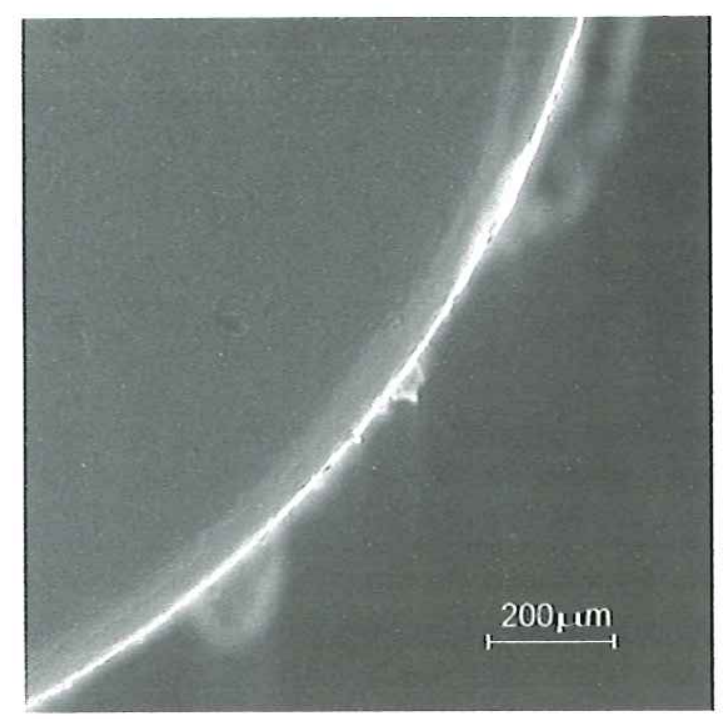

Figura 39 - Inserto de metal duro 3015 desgastado no torneamento a seco de ferro fundido cinzento GG25 ( $\left.v_{c} 1000 \mathrm{~m} / \mathrm{min}\right)$

\subsection{2 - Metal Duro (velocidade de corte $1350 \mathrm{~m} / \mathrm{min}$ e avanço 0,08 $\mathrm{mm} /$ volta)}

Na Figura 40(a) tem-se uma visão geral da aresta de corte desgastada do inserto de metal duro com cobertura no torneamento a seco de ferro fundido cinzento GG25 com velocidade de corte $1350 \mathrm{~m} / \mathrm{min}$. Observa-se grande desgaste de flanco ao longo da aresta de corte do inserto, devido principalmente a alta velocidade de corte. Na Figura 40(b) observa-se o detalhe, aparentemente, de camada delaminada (VLEUGELS \& VAN DER BIEST, 1998), devido às altas temperaturas da região de corte conseqüência da alta velocidade de corte. Nestas fotografias não há indícios de abrasão mecânica, adesão de material usinado e desgaste de cratera sobre a superfície de saída. 


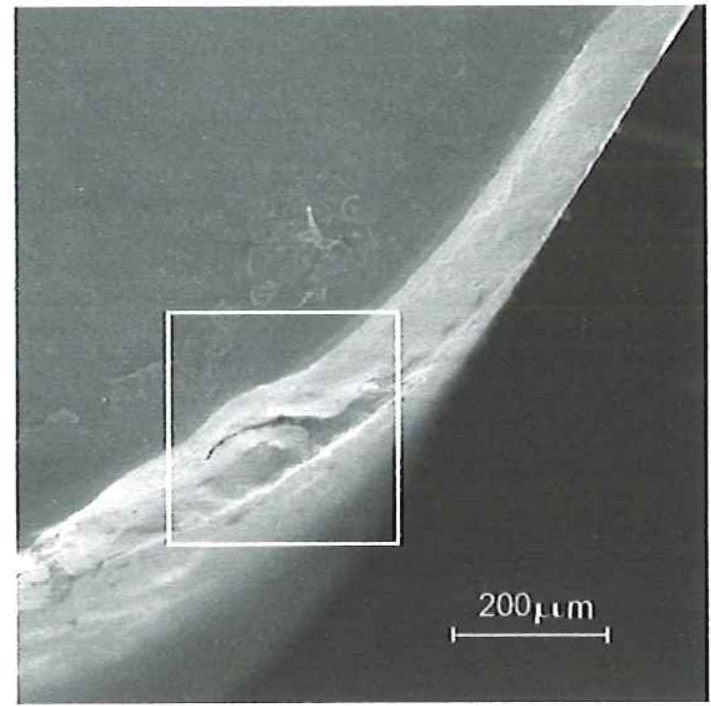

(a) Visão Geral

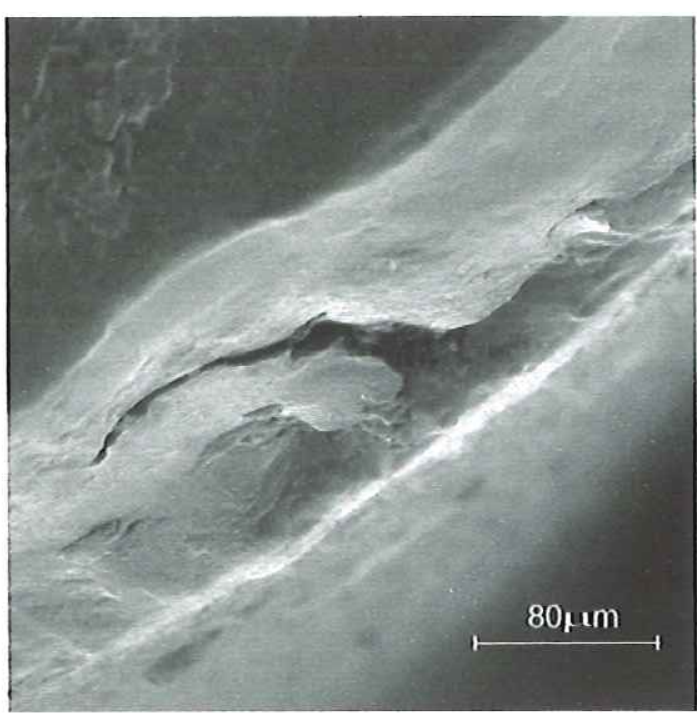

(b) Detalhe de delaminação

Figura 40 - Inserto de metal duro 3015 desgastado no torneamento a seco de ferro fundido cinzento GG25 ( $\left.v_{c} 1350 \mathrm{~m} / \mathrm{min}\right)$

Na Figura 41 tem-se uma visão geral da aresta de corte desgastada do inserto de metal duro com cobertura no torneamento com lubrificação MQL (vazão de óleo $12 \mathrm{ml} / \mathrm{h}$ e vazão de $\operatorname{ar} 18 \mathrm{~m}^{3} / \mathrm{h}$ ) de ferro fundido cinzento GG25 com velocidade de corte $1350 \mathrm{~m} / \mathrm{min}$. Observa-se desgaste de flanco bem menor que no torneamento a seco. Podem notar desgastes do tipo entalhe na aresta primária e secundária de corte. Não se observa camada delaminada, provavelmente devido à eficiente lubrificação MQL que minimiza a temperatura da região de corte. Também não se nota desgaste de cratera sobre a superfície de saída.

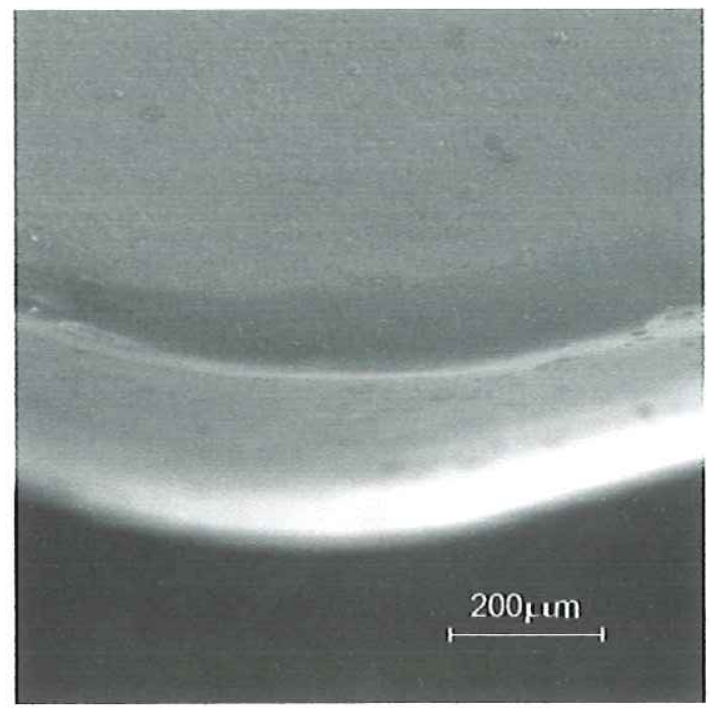

Figura 41 - Inserto de metal duro 3015 desgastado no torneamento com MQL (vazão de óleo $12 \mathrm{ml} / \mathrm{h}$ e vazão de ar $\left.18 \mathrm{~m}^{3} / \mathrm{h}\right)$ de ferro fundido cinzento GG25 $\left(\mathrm{v}_{\mathrm{c}} 1350 \mathrm{~m} / \mathrm{min}\right)$ 


\subsection{3 - Metal Duro e Cerâmica (velocidade de corte $1700 \mathrm{~m} / \mathrm{min}$ e avanço $0,08 \mathrm{~mm} /$ volta)}

Na Figura 42(a) tem-se uma visão geral da aresta de corte desgastada do inserto de metal duro com cobertura no torneamento a seco de ferro fundido cinzento GG25 com velocidade de corte $1700 \mathrm{~m} / \mathrm{min}$. Observa-se enorme desgaste de flanco e a quebra do inserto. Nota-se uma grande delaminação. Não se nota desgaste de cratera sobre a superfície de saída.

A Figura 42(b) mostra indícios de abrasão mecânica, primeiro, provavelmente devido às altas temperaturas de corte e depois devido às partículas duras, tais como carbonetos, presentes no material da peça. Notam-se também pequenos sinais de adesão de material usinado.

No detalhe da Figura 42(c) observa-se aparentemente um forte indício de adesão de material da peça. Ao redor da adesão tem sinais de abrasão mecânica. 


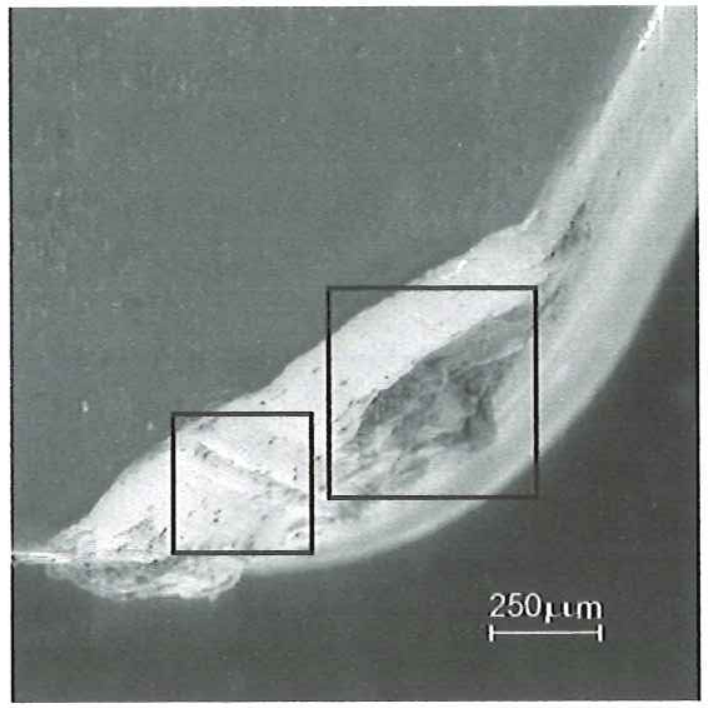

(a) Visão Geral

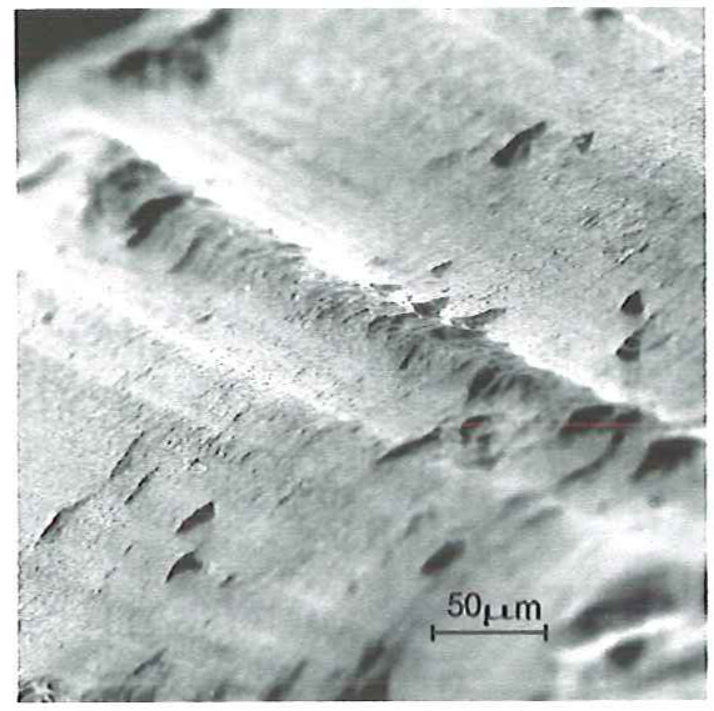

(b) Detalhe de abrasão

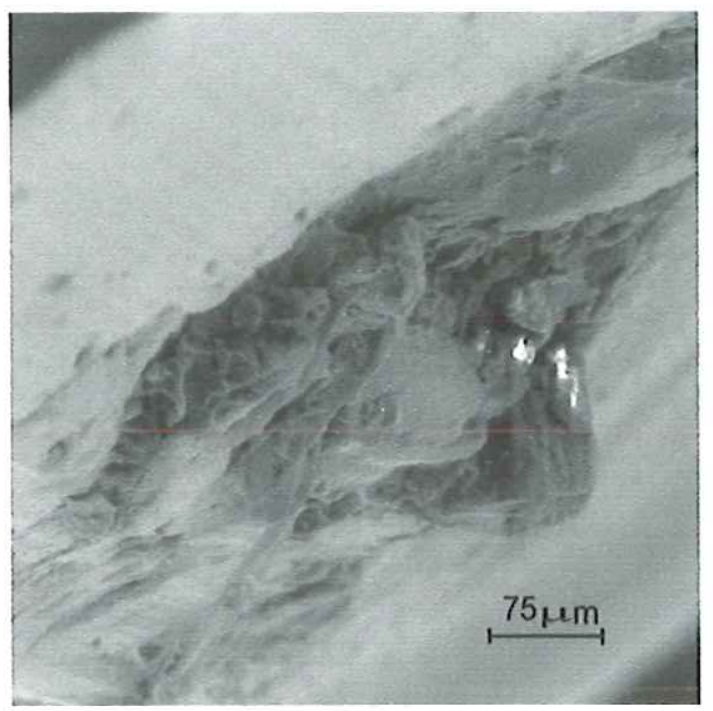

(c) Detalhe de adesão

Figura 42 - Inserto de metal duro 3015 desgastado no torneamento a seco de ferro fundido cinzento GG25 ( $\left.v_{c} 1700 \mathrm{~m} / \mathrm{min}\right)$

Na Figura 43(a) tem-se uma visão geral da aresta de corte desgastada do inserto de metal duro com cobertura no torneamento com lubrificação MQL (vazão de óleo $12 \mathrm{ml} / \mathrm{h}$ e vazão de ar $18 \mathrm{~m}^{3} / \mathrm{h}$ ) de ferro fundido cinzento GG25 com velocidade de corte $1700 \mathrm{~m} / \mathrm{min}$. Observa-se desgaste de flanco bem menor que no torneamento a seco e não ocorre quebra do inserto. O processo de delaminação não se manifesta, provavelmente devido à lubrificação $\mathrm{e}$ refrigeração. Não se nota desgaste de cratera sobre a superfície de saída. No detalhe da Figura 43(b) tem fortes indícios de adesão de material usinado. 


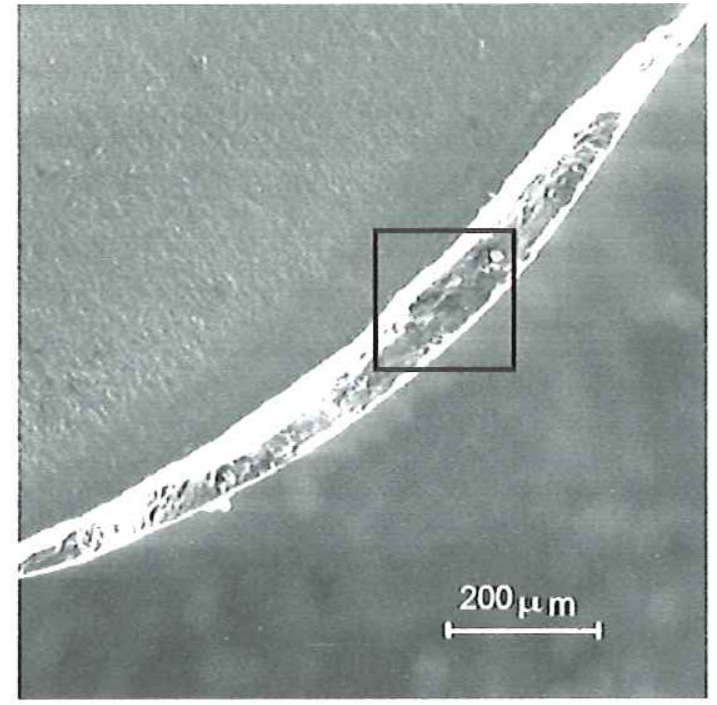

(a) Visão Geral

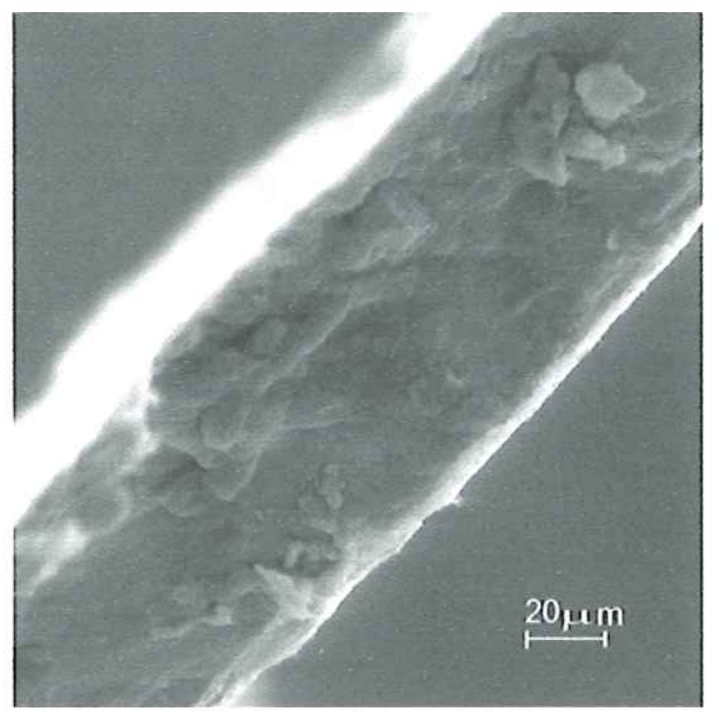

(b) Detalhe de adesão

Figura 43 - Inserto de metal duro 3015 desgastado no torneamento com MQL (vazão de óleo $12 \mathrm{ml} / \mathrm{h}$ e vazão de ar $\left.18 \mathrm{~m}^{3} / \mathrm{h}\right)$ de ferro fundido cinzento GG25 $\left(\mathrm{v}_{\mathrm{c}} 1700 \mathrm{~m} / \mathrm{min}\right)$

Na Figura 44(a) tem-se uma visão geral da aresta de corte desgastada do inserto de cerâmica no torneamento a seco de ferro fundido cinzento GG25 com velocidade de corte $1700 \mathrm{~m} / \mathrm{min}$. Observa-se nitidamente o desgaste de flanco, não ocorre a quebra do inserto. Não se nota desgaste de cratera sobre a superfície de saída.

No detalhe da Figura 44(b) nota-se que o processo de delaminação se manifesta mais próximo à superfície de folga. Próximo da superfície de saída nota-se indícios de abrasão mecânica. Observam-se poucos indícios de adesão de material usinado.

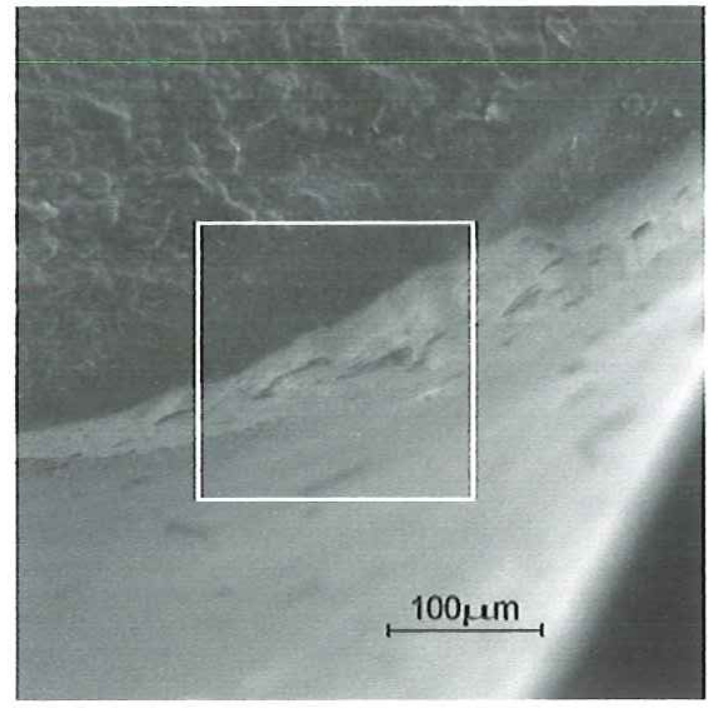

(a) Visão Geral

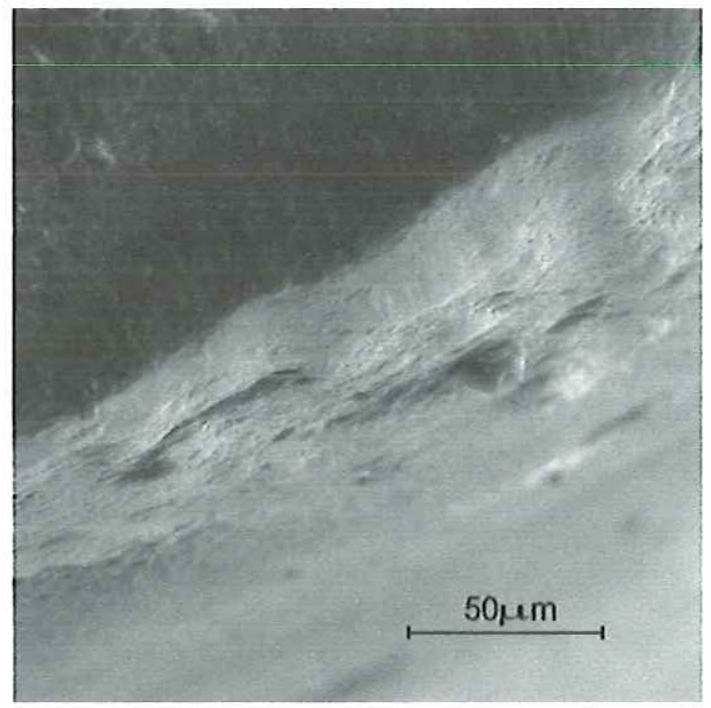

(b) Detalhe de delaminação e abrasão

Figura 44 - Inserto de cerâmica CC650 desgastado no torneamento a seco de ferro fundido cinzento GG25 ( $\left.\mathrm{v}_{\mathrm{c}} 1700 \mathrm{~m} / \mathrm{min}\right)$ 


\subsection{4 - Cerâmica (velocidade de corte $1700 \mathrm{~m} / \mathrm{min}$ e avanço 0,10 $\mathrm{mm} /$ volta)}

Na Figura 45(a) tem-se uma visão geral da aresta de corte desgastada do inserto de cerâmica no torneamento a seco de ferro fundido cinzento GG25 com velocidade de corte $1700 \mathrm{~m} / \mathrm{min}$. Observa-se menor desgaste de flanco que para avanço $0,08 \mathrm{~mm} /$ volta (Figura 44), não ocorre a quebra do inserto. Não se nota desgaste de cratera sobre a superfície de saída. Pode-se notar desgaste do tipo entalhe na aresta de corte.

No detalhe da Figura 45(b) verifica-se indícios de abrasão mecânica e delaminação (mais próximo da superficie de folga). No detalhe da Figura 45(c) nota-se desgaste do tipo entalhe.

Não se observa adesão de material usinado. 


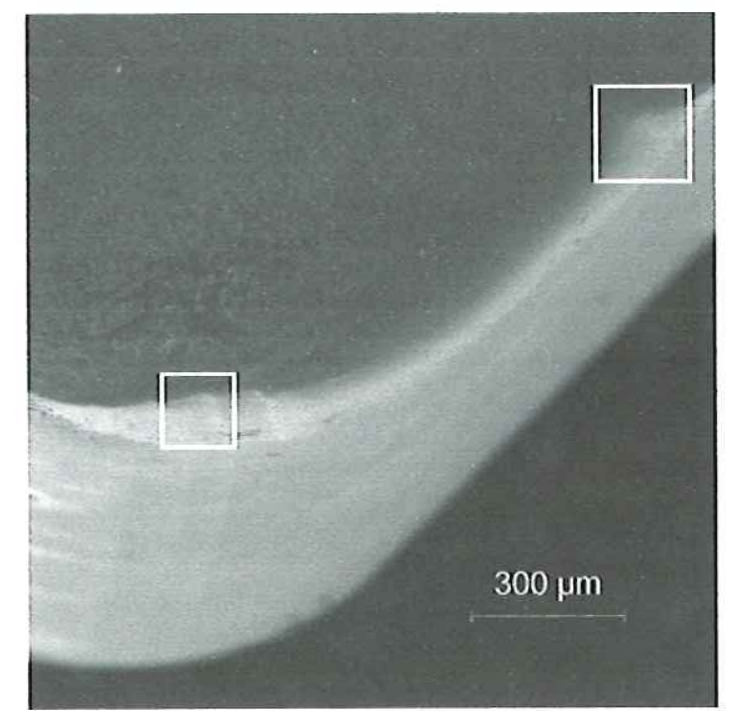

(a) Visão Geral

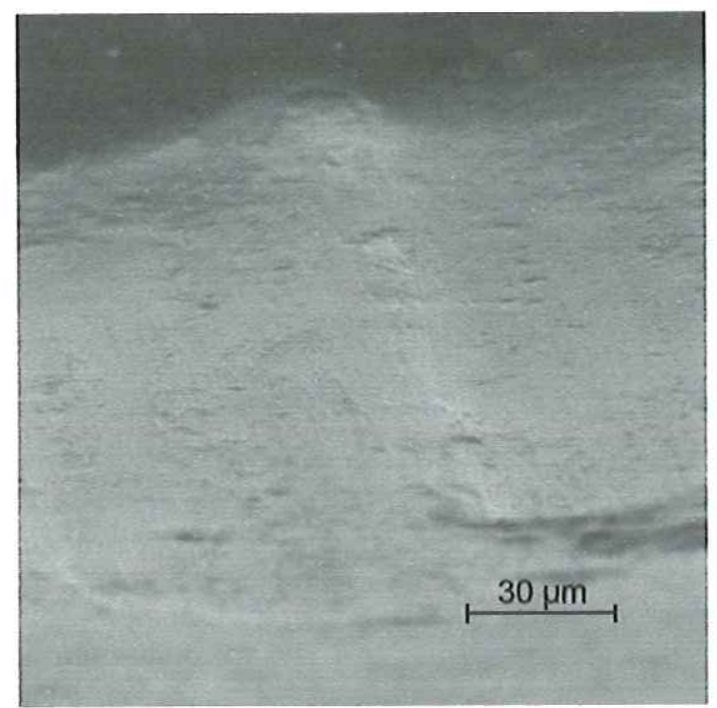

(b) Detalhe de abrasão

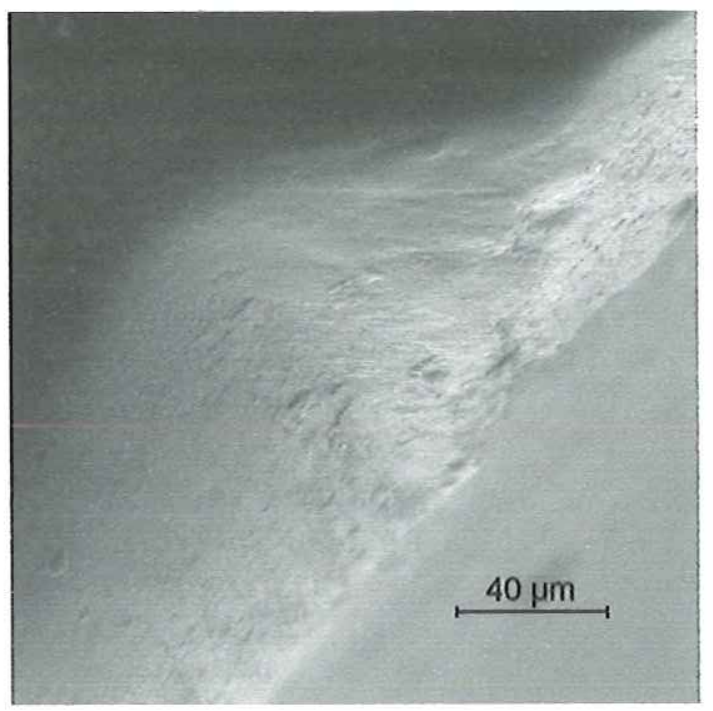

(c) Detalhe de entalhe

Figura 45 - Inserto de cerâmica CC650 desgastado no torneamento a seco de ferro fundido cinzento GG25 ( $v_{c} 1700 \mathrm{~m} / \mathrm{min}$ e avanço $0,10 \mathrm{~mm} /$ volta $)$

Na Figura 46(a) tem-se uma visão geral da aresta de corte desgastada do inserto de cerâmica no torneamento de ferro fundido cinzento GG25 com lubrificação MQL (vazão de óleo $10 \mathrm{ml} / \mathrm{h}$ e vazão de ar $9 \mathrm{~m}^{3} / \mathrm{h}$ ) com velocidade de corte $1700 \mathrm{~m} / \mathrm{min}$. Observa-se menor desgaste de flanco que no torneamento a seco (Figura 45), mas observam-se desgastes do tipo entalhe na aresta primária e secundária de corte mais destacados. Não se nota desgaste de cratera sobre a superfície de saída.

O detalhe da Figura 46(b) mostra desgaste do tipo entalhe e poucos indícios de delaminação. Não se observa adesão de material usinado. 


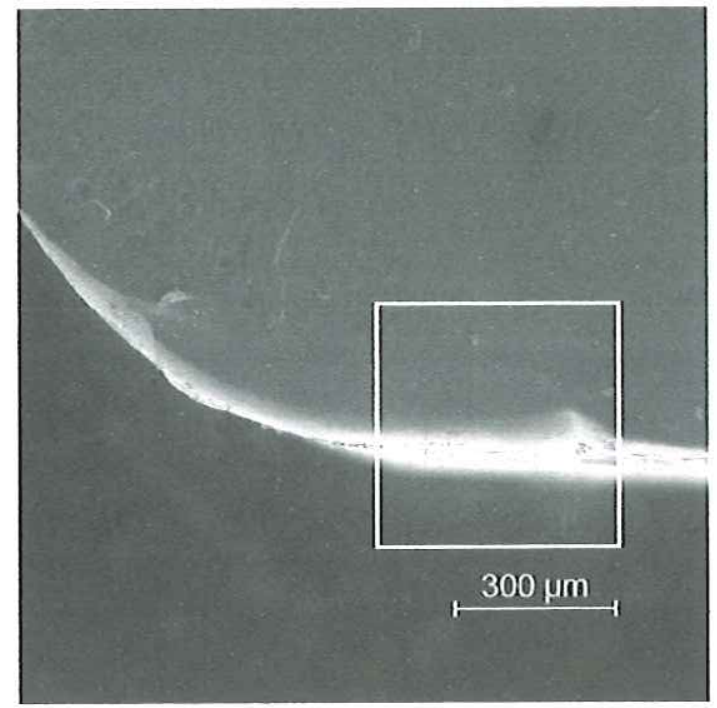

(a) Visão Geral

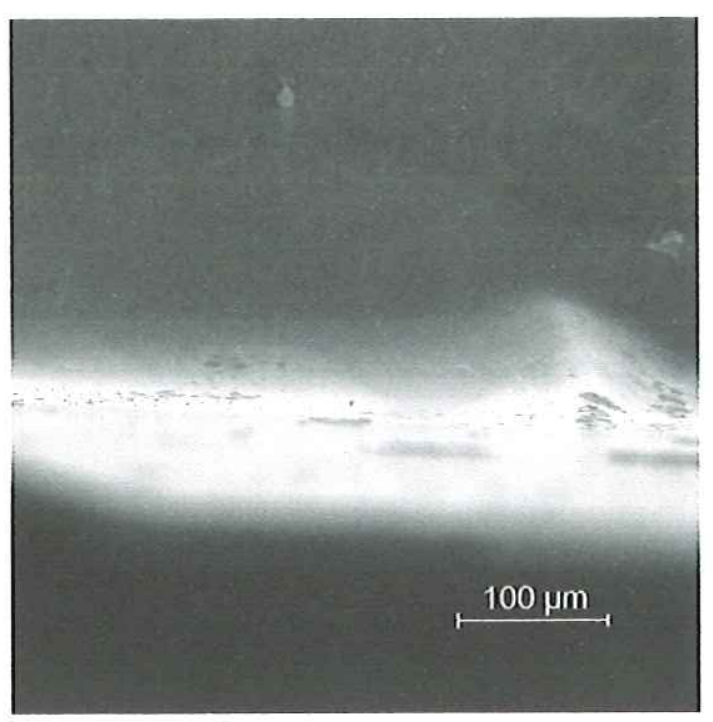

(b) Detalhe de entalhe

Figura 46 - Inserto de cerâmica CC650 desgastado no torneamento de ferro fundido cinzento GG25 (lubrificação MQL: vazão de óleo $10 \mathrm{ml} / \mathrm{h}$ e vazão de $\left.\operatorname{ar} 9 \mathrm{~m}^{3} / \mathrm{h}\right)\left(\mathrm{v}_{\mathrm{c}} 1700 \mathrm{~m} / \mathrm{min}\right.$ e avanço $0,10 \mathrm{~mm} /$ volta)

Na Figura 47(a) tem-se uma visão geral da aresta de corte desgastada do inserto de cerâmica no torneamento de ferro fundido cinzento GG25 com lubrificação MQL (vazão de óleo $20 \mathrm{ml} / \mathrm{h}$ e vazão de ar $9 \mathrm{~m}^{3} / \mathrm{h}$ ) com velocidade de corte $1700 \mathrm{~m} / \mathrm{min}$. Observa-se desgaste de flanco e indícios de abrasão mecânica, não se observam desgastes do tipo entalhe como no caso anterior (Figura 46). Notam-se poucos indícios de delaminação e não se observa adesão de material usinado.

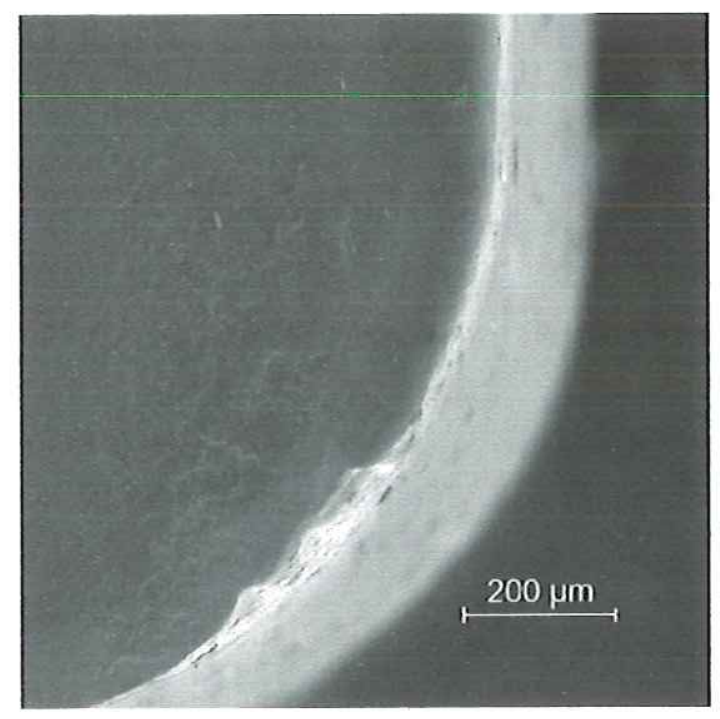

Figura 47 - Inserto de cerâmica CC650 desgastado no torneamento de ferro fundido cinzento GG25 (lubrificação MQL: vazão de óleo $20 \mathrm{ml} / \mathrm{h}$ e vazão de $\left.\operatorname{ar} 9 \mathrm{~m}^{3} / \mathrm{h}\right)\left(\mathrm{v}_{\mathrm{c}} 1700 \mathrm{~m} / \mathrm{min} \mathrm{e}\right.$ avanço $0,10 \mathrm{~mm} /$ volta) 


\subsection{5 - Resumo sobre a análise de desgaste}

$\mathrm{O}$ desgaste ocorre de forma diferenciada para algumas condições de usinagem. $\mathrm{O}$ desgaste de flanco é dominante em todas as condições de usinagem, independente da velocidade de corte, lubrificação e material do inserto. Confirma-se que todo processo de usinagem causa este tipo de desgaste (DINIZ et al., 1999).

Observa-se que não existe mecanismo de desgaste único, o desgaste é proveniente de uma combinação de mecanismos (VLEUGELS \& VAN DER BIEST, 1998).

Os desgastes de flanco são mais acentuados quanto maiores as velocidades de corte. Com relação à lubrificação, o sistema MQL é muito eficiente na redução do desgaste de flanco, provavelmente pela diminuição da temperatura de corte através da refrigeração.

Notam-se mecanismos de delaminação, principalmente em altas velocidades de corte $\mathrm{e}$ torneamento a seco, provavelmente devido às altas temperaturas de corte na aresta durante a usinagem, tanto para metal duro com cobertura como para cerâmica. Nos ensaios com lubrificação $\mathrm{MQL}$, verifica-se menor delaminação, o que comprova a eficiência da lubrificação MQL com relação ao efeito de refrigeração.

Em altas velocidades de corte $(1700 \mathrm{~m} / \mathrm{min})$ no torneamento a seco, notam-se indícios de abrasão mecânica, devido principalmente às altas temperaturas de corte, que reduzem a dureza do material do inserto e em segundo lugar devido à presença de partículas duras, tais como carbonetos existentes na matriz de ferro fundido cinzento. No torneamento a seco com velocidades de corte menores não se observam fortes indícios de abrasão mecânica.

Indícios de adesão são mais evidentes em velocidade de corte maiores e avanço menores ( $0,08 \mathrm{~mm} /$ volta), independente da lubrificação (Figura 42, Figura 43 e Figura 44).

Não se observam desgaste de cratera, lascamento ou trincas.

Portanto os mecanismos de desgastes dominantes no torneamento de ferro fundido cinzento são delaminação, abrasão mecânica e aderência.

Com relação ao material do inserto verifica-se que devido a menor dureza do metal duro, este tem maiores indícios de abrasão mecânica. Como a cerâmica é à base de alumina, esta possui maior resistência ao desgaste, conseqüentemente tem menor desgaste de flanco.

Resumindo, com o aumento da velocidade de corte aumenta-se o processo de delaminação, abrasão mecânica e adesão de material da peça. A lubrificação $\mathrm{MQL}$ reduz o processo de delaminação e abrasão mecânica, ambos dependentes da temperatura na região de corte. 


\section{3 - DISCUSSÃO FINAL}

Nos ensaios, os insertos de cerâmica apresentam um melhor desempenho, tanto em relação ao desgaste de flanco como em relação à rugosidade superficial. A classe de cerâmica utilizada (mista $\mathrm{Al}_{2} \mathrm{O}_{3}+\mathrm{TiC}$ ), em relação às outras cerâmicas, é a ideal para usinagem de ferro fundido (KATSUMURA et al., 1993).

Devido à pequena taxa de avanço (operação de acabamento), os cavacos são minúsculos, sendo esta massa de cavaco insuficiente para retirar quantidade razoável de calor do processo de corte, portanto, atinge-se altas temperaturas de corte, e as estabilidades química e térmica são imprescindíveis.

As condições de usinagem encontradas com bom desempenho nos ensaios são:

- Metal Duro: $v_{c} 1350 \mathrm{~m} / \mathrm{min}$ com lubrificação MQL;

- Cerâmica: $\mathrm{v}_{\mathrm{c}} 1700 \mathrm{~m} / \mathrm{min}$ com lubrificação MQL.

Nota-se que a máxima velocidade de corte recomendada pelo fabricante para o inserto de metal duro é $305 \mathrm{~m} / \mathrm{min}$, isto é, $\mathrm{v}_{\mathrm{c}}$ do ensaio é $343 \%$ maior que a recomendada. No caso do inserto de cerâmica, a máxima velocidade de corte recomendada é $700 \mathrm{~m} / \mathrm{min}$ e no ensaio utiliza-se $\mathrm{v}_{\mathrm{c}}$ somente $143 \%$ maior. Pode-se dizer que os dados dos fabricantes são genéricos e com alteração das condições de usinagem pode-se obter melhores resultados.

O inserto de metal duro possui uma camada externa de TiN, que reduz o coeficiente de atrito entre a ferramenta e o cavaco (TEETER, 1994), sendo que na aresta de corte esta camada é rapidamente desgastada nos primeiros faceamentos, por este fato, nos gráficos de desgaste de flanco existe um desgaste primário significante (MILLS \& REDFORD, 1983).

Todos os gráficos de desgaste de flanco versus percurso de avanço mostram as definições de MILLS \& REDFORD (1983): desgaste primário alto, desgaste secundário constante e desgaste terciário alto. Tanto para ensaios a seco como com lubrificação MQL, independentemente da velocidade de corte e do material do inserto. Sendo que a lubrificação MQL prolonga cada etapa de desgaste.

Com relação aos valores de rugosidade superficial Ra obtidos, notam-se elevadas diferenças em relação aos valores de Ra ideal (Tabela 11). Para possibilitar uma melhor comparação, realiza-se o polimento de três amostras do material GG25 e encontram-se valores na ordem de Ra 0,11 $\mu \mathrm{m}$. Provavelmente os elevados valores de Ra devem-se as pequenas vibrações causadas pelo sistema de fixação do volante na placa do torno $\mathrm{CNC}$ (item 3.6.1). Este sistema é como uma viga em balanço com uma carga com grande inércia na extremidade. 
A grande dispersão dos valores de Ra, provavelmente deve-se à estrutura superficial do GG25, isto é, elevada quantidade de grafita e alguns aspectos de cementita.

O valor Ra, no caso do ferro fundido cinzento, não é um bom indicador de critério de fím de vida da ferramenta, por causa de sua grande variação e nenhuma relação com o desgaste da ferramenta. Somente é um indicador quando existe limite do valor de rugosidade.

Conforme observa-se no APÊNDICE VII, as condições de usinagem da Empresa Auto Pira, fabricante dos volantes, são diferentes das utilizadas nos ensaios experimentais. Devese ao fato que o trabalho experimental refere-se a uma operação de acabamento e utiliza-se outro fabricante de inserto, portanto, adota-se um avanço menor para obter uma menor rugosidade superficial (APÊNDICE II) e com relação ao raio de ponta, devido à alta rotação empregada, adota-se um raio de ponta menor, visando menor vibração. Na Tabela 12, tem-se a comparação entre os insertos. A velocidade de corte do inserto utilizado pela empresa, suporta velocidade até $71 \%$ maior que o inserto de cerâmica utilizado nos ensaios.

Tabela 12 - Comparações entre os insertos utilizados e do fabricante dos volantes

\begin{tabular}{|c|c|c|c|}
\cline { 2 - 4 } \multicolumn{1}{c|}{} & Ensaio & Ensaio & Auto Pira \\
\hline Código ISO & SNMA 120408 & SNGA 120408 & CNGA 120416 \\
\hline Material & $\begin{array}{c}\text { Metal Duro } \\
\text { TiCN/ } \mathrm{Al}_{2} \mathrm{O}_{3} / \mathrm{TiN}\end{array}$ & $\begin{array}{c}\text { Cerâmica } \\
\mathrm{Al}_{2} \mathrm{O}_{3}+\mathrm{TiC}\end{array}$ & $\begin{array}{c}\text { Cerâmica } \\
\mathrm{Al}_{2} \mathrm{O}_{3}(70 \%)+\mathrm{TiC}(30 \%)\end{array}$ \\
\hline Forma do Inserto & quadrada & quadrada & rômbica (80 $)$ \\
\hline Raio de Ponta (mm) & 0,8 & 0,8 & 1,6 \\
\hline Arestas & 8 & 8 & 4 \\
\hline $\mathrm{v}_{\mathrm{c}}$ máxima $(\mathrm{m} / \mathrm{min})$ & 305 & 700 & 1200 \\
\hline
\end{tabular}

Por causa destas diferenças, não há possibilidade de comparações reais com as condições de usinagem do fabricante dos volantes. 


\section{5 - CONCLUSÕES}

A partir da análise dos resultados obtidos nos ensaios experimentais de torneamento com alta velocidade de ferro fundido cinzento e, com base na literatura técnica revisada, pode-se concluir que:

- O sistema de lubrificação MQL diminui o desgaste dos insertos testados. No caso de insertos de cerâmica maiores valores de vazão de óleo/ar proporcionam menor desgaste de flanco;

- Cerâmica mista $\left(\mathrm{Al}_{2} \mathrm{O}_{3}-\mathrm{TiC}\right)$ tem desgaste de flanco inferior que metal duro com cobertura ( $\mathrm{TiCN} / \mathrm{Al}_{2} \mathrm{O}_{3} / \mathrm{TiN}$ ) quando testadas nas condições utilizadas nesse trabalho;

- O tipo de desgaste predominante é o desgaste de flanco;

- Os mecanismos de desgaste predominantes são a abrasão mecânica e a delaminação;

- Com o aumento da velocidade de corte aumenta-se o processo de delaminação, abrasão mecânica e adesão de material da peça;

- A lubrificação MQL reduz o processo de delaminação e abrasão mecânica, ambos dependentes da temperatura na região de corte;

- O aumento da velocidade de corte aumenta o desgaste de flanco;

- Não se encontra uma relação clara entre desgaste de flanco e rugosidade superficial da peça usinada;

- O aumento do avanço diminui o desgaste de flanco, nas condições testadas;

- A rugosidade superficial Ra varia muito ao longo da vida do inserto e há uma grande dispersão nos valores medidos;

- O parâmetro Ra não mostra ser um bom indicador para detectar o início de fim de vida do inserto. 


\section{6 - SUGESTÕES PARA TRABALHOS FUTUROS}

Baseando-se no trabalho experimental realizado, pode-se fazer algumas sugestões para trabalhos futuros, no intuito de obter maiores conhecimentos do torneamento de alta velocidade de ferro fundido cinzento GG25 a seco e com MQL:

- Realizar ensaios com mais tipos de materiais para ferramentas, tais como, metal duro com diferentes coberturas, cermets, cerâmica mista, sialon e PCBN;

- Utilizar uma maior variação de velocidade de corte, avanço e profundidade de corte;

- Utilizar somente ar comprimido, para verificar a real eficácia do MQL;

- Utilizar fluido de corte líquido;

- Realizar uma análise econômica da real vantagem ou desvantagem da lubrificação MQL. 


\section{ANEXO A - Principais características dos ferros fundidos}

\section{1 - Ferro Fundido Branco (coquilhado)}

- Denominação devido à fratura de coloração clara;

- Apresenta como elementos fundamentais de liga o carbono e o silício;

- Devido às condições de fabricação (velocidade de resfriamento rápido) e menor teor de silício, a estrutura apresenta o carbono quase inteiramente na forma combinada cementita $\left(\mathrm{Fe}_{3} \mathrm{C}\right)$, portanto, não ocorre a formação de grafita;

- A estrutura da matriz é perlítica;

- Elementos de liga: níquel, cromo e molibdênio, isolados ou em combinação, aumentam a resistência ao desgaste; vanádio é um poderoso estabilizador de carboneto (CHIAVERINI, 1984);

- Propriedades: elevada dureza em altas temperaturas; fragilidade; elevada resistência ao desgaste, à compressão e à abrasão; e ductilidade praticamente nula;

- Usinabilidade prejudicada devido as suas propriedades;

- Aplicações são geralmente devidas à excelente resistência ao desgaste e à abrasão (ASM, 1978): equipamento de manuseio de terra, mineração, moagem, rodas de vagões, cilindros coquilhados, revestimento de moinhos, etc.

\section{2 - Ferro Fundido Mesclado}

Denominação devido à fratura de coloração mista entre branca e cinzenta. Apresenta igualmente uma mescla de proporção variável de ferro fundido branco e cinzento.

\section{3 - Ferro Fundido Maleável}

- Obtido a partir do ferro fundido branco, mediante um tratamento térmico especial (maleabilização), que resulta numa transformação de praticamente todo o ferro combinado em grafita na forma de nódulos (em vez de veios ou lamelas);

- A microestrutura final é um agregado de ferrita e grafita (BRESCIANI FILHO, 1988);

- Liga intermediária entre o aço e o ferro fundido cinzento;

- Propriedades: ductilidade, tenacidade, resistência à tração, dureza, resistência à fadiga, resistência ao desgaste, resistência à corrosão (devido à camada superficial de ferrita 
ligada com silício na faixa de 0,80 a $1,7 \%$ ), resistência ao choque, resistência às deformações, boa usinabilidade - melhor entre as ligas ferrosas de idêntica resistência mecânica - (CHIAVERINI, 1984) e alta fluidez no estado líquido, que permite a produção de peças complexas e finas; pode ser galvanizado;

- Dependendo do processo de maleabilização pode apresentar núcleo preto ou branco;

- Ferro fundido maleável de núcleo preto (ou americano) passa por um tratamento térmico em atmosfera neutra, em que a cementita se decompõe em ferro e carbono e, no qual, o carbono forma uma grafita compacta, diferente da forma laminada dos ferros fundidos cinzentos. Ele é usado para a fabricação de suportes de molas, caixas de direção, cubos de rodas, bielas, conexões para tubulações hidráulicas e industriais;

- Ferro fundido maleável de núcleo branco passa por um tratamento térmico em atmosfera oxidante, no qual o carbono é removido por descarbonetação, não há formação de grafita. Por causa disso, ele adquire características semelhantes às de um aço de baixo carbono e pode ser soldado. É um material indicado para a fabricação de barra de torção, corpo de mancal e flanges para tubos de escapamento.

\section{4 - Ferro Fundido Nodular (dúctil)}

- Realiza-se um tratamento ainda no estado líquido, chamado de nodulização (BRESCIANI FILHO, 1988), adição precisa de uma pequena quantidade de magnésio ou cério (ASM, 1978), e forma-se carbono livre na forma de grafita esferoidal, que confere características de boa ductilidade. Segundo BRESCIANI FILHO (1988), por isso também é denominado de ferro fundido de grafita esferoidal;

- Antes, durante e após a nodulização existe o processo de inoculação, que determina o tamanho e a distribuição das partículas esferoidizadas (BRESCIANI FILHO, 1988);

- A estrutura típica da matriz é perlítica, contudo os nódulos de grafita encontram-se envolvidos por ferrita; sendo que algumas vezes, a cementita livre pode estar presente (BRESCIANI FILHO, 1988);

- Propriedades segundo ASM (1978): ductilidade, tenacidade, resistência mecânica (elevado limite de escoamento), grande módulo de elasticidade, resistência ao choque, resistência à fadiga, resistência ao desgaste (devido a tratamento térmico); sendo a fluidez, a usinabilidade e a resistência à corrosão comparável ao ferro fundido cinzento, exceto que o ferro fundido nodular tem melhor resistência à oxidação em temperaturas elevadas que ferro fundido cinzento; 
- Por causa dessas características (principalmente resistência mecânica e ductilidade) e do menor custo de processamento, está substituindo alguns tipos de aços e os ferros fundidos maleáveis na maioria de suas aplicações;

- Aplicações: mancais, virabrequins, cubos de roda, caixas de diferencial, peças de sistema de transmissão de automóveis, caminhões e tratores. 


\section{ANEXO B - Principais características dos fluidos de corte}

\section{1 - Fluidos de corte sólidos}

Os sólidos utilizados visam apenas a lubrificação no processo de usinagem e são de duas formas distintas (RUFFINO, 1977):

a) lubrificante sólido: aplicação de um pó (fina camada de grafite ou bissulfeto de molibdênio, com graxa ou óleo viscoso) diretamente na superficie de saída da ferramenta, antes da operação de usinagem. Sua função é redução do coeficiente de atrito do escorregamento do cavaco;

b) aditivo metalúrgico: elementos adicionados durante a fabricação do metal a ser usinado, com a finalidade de melhorar sua usinabilidade (ação de lubrificante interno, ação de redução das pressões e soldagens locais na interface ferramenta-cavaco) (item 2.2).

\section{2 - Fluidos de corte líquidos}

É o maior grupo de fluidos de corte e o mais empregado. Os líquidos utilizados visam principalmente a lubrificação e a refrigeração no processo de usinagem. Através de apenas duas vias o líquido pode atingir a região onde é necessário (RUFFINO, 1977):

- superfície de saída: o meio mais empregado;

- superfície de folga: o meio que tem apresentado melhores resultados em ensaios comparativos.

Os fluidos de corte líquidos podem ser divididos nos seguintes grupos:

- tipo aquoso: água e emulsões;

- óleos: minerais, graxos e compostos;

- químicos e

- mercúrio.

2.1) FLUIDO DE CORTE TIPO AQUOSO: os fluidos de corte tipo aquoso são os de maior poder de refrigeração:

a) Água:

É o primeiro fluido de corte utilizado, sendo exclusivamente para refrigeração (um dos meios mais efetivos), mas atualmente quase não é utilizado em produção. Suas 
vantagens são: abundância, baixo preço, não é inflamável e baixa viscosidade. Suas desvantagens são: provoca corrosão de materiais ferrosos e baixo poder umectante nos metais (DINIZ et al., 1999).

b) Emulsões:

As desvantagens da água podem ser removidas através de aditivos - agentes antiferruginosos e lubrificantes (RUFFINO, 1977). Os emulsificadores são substâncias que reduzem a tensão superficial da água, facilitam a dispersão do óleo na água e mantém finamente disperso como uma emulsão estável (DINIZ et al., 1999). Esta emulsão estável recebe o nome de óleo solúvel ou óleo emulsionável (RUFFINO, 1977) ou simplesmente emulsão (DINIZ et al., 1999). Normalmente a porcentagem de óleo na emulsão varia de 1 a $20 \%$, portanto, a emulsão possui um poder refrigerante incomparável (DINIZ et al., 1999). As emulsões mais fracas são indicadas para operações de corte leves ( $\mathrm{f} \mathrm{e} \mathrm{a}_{\mathrm{p}}$ baixas e médias, e $\mathrm{v}_{\mathrm{c}}$ média e alta), onde a necessidade de refrigeração é dominante, por outro lado, as emulsões mais ricas apresentam melhores propriedades lubrificantes e anti-oxidantes (RUFFINO, 1977). Em operações com baixas velocidades de corte (tendência de formação de aresta postiça de corte) e altos avanços e profundidades de usinagem (geração de calor alta) a lubrificação é necessária, portanto, o óleo puro é preferível (DINIZ et al., 1999). Os tipos de emulsão de óleo em água são (RUFFINO, 1977):

- emulsão de óleos minerais: mais largamente usado, baixo custo, boa capacidade anti-oxidante e suficiente lubrificação;

- emulsão de óleos supergraxos: operações de usinagem mais severas;

- emulsão de óleos de extrema pressão EP: poder lubrificante, usinagem severa (onde os anteriores não satisfazem) e redução do problema de fumaça e vapores na região de corte nos cortes pesados. Contém aditivos de extrema pressão: enxofre, cloro, fósforo e também gorduras; que facilitam a formação de uma película sobre a peça usinada e reduz o atrito ferramenta/peça (NACHTMAN, 1989).

2.2) ÓLEOS: os óleos têm maior poder de lubrificação e quanto menor a viscosidade, maior o seu poder de refrigeração. São óleos que não são misturados com água, podem ser classificados em ativos ou inativos, segundo sua atividade química ou habilidade em reagir com a superfície metálica (nos pontos de alta temperatura para protege-la e melhorar a usinagem) (RUFFINO, 1977).

Nos óleos ativos são acrescentados aditivos, tais como enxofre e cloro (DINIZ et al., 1999) (RUFFINO, 1977): 
- enxofre (normalmente livre ou combinado): devido às altas temperaturas de corte, parte do enxofre reage quimicamente com a superfície nascente do cavaco (RUFFINO, 1977). Segundo DINIZ et al. (1999), o enxofre reage quimicamente com os materiais envolvidos, para suportar extremas pressões e fixar-se às superfícies em contato, formando um composto que apresenta uma resistência ao corte muito inferior àquela do metal em trabalho, evitando a soldagem e a formação da aresta postiça de corte. Estes óleos ativos são geralmente usados na usinagem dos aços, podem ser escuros (mais enxofre) ou transparentes, sulfurados puros ou sulfoclorados, minerais ou mistos com óleos graxos. Os óleos escuros são mais indicados para usinagens mais severas (RUFFINO, 1977), mas não podem usinar cobre e suas ligas, pois estes são corroídos pelo enxofre (DINIZ et al., 1999);

- cloro: forma uma película metálica clorada na interface ferramenta-cavaco. Os compostos clorados quando quimicamente ativos tem atuação similar à dos compostos sulfurados, porém a temperaturas mais baixas.

Os aditivos enxofre e cloro conferem ao óleo de corte as propriedades de óleo de extrema pressão (EP) e anti-soldante (RUFFINO, 1977).

Os óleos EP suportam elevadas pressões sem vaporizar, condições estas presentes em operações com altas velocidades e profundidades de usinagem de materiais que geram elevadas forças de corte (DINIZ et al., 1999).

\section{a) Óleos minerais:}

- óleos minerais puros (inativo): devido a sua baixa viscosidade, tem a capacidade de molhar e infiltrar mais rapidamente nas regiões necessárias, portanto, são indicados para usinagem leve de metais não-ferrosos (alumínio, bronze, magnésio,latão e ligas leves) e aços de fácil corte (baixo carbono) (RUFFINO, 1977). São mais baratos e menos sujeitos à oxidação que os óleos graxos e óleos compostos, sendo que os mais finos podem ser usados em operações de retificação (DINIZ et al., 1999);

- óleos minerais sulfurados (ativo): tem enxofre como aditivo, conferindo melhores propriedades anti-soldantes, melhor poder lubrificante e alta atividade química. Recomendado para usinagem geral e severa de metais tenazes e altamente dúcteis (aços de baixo carbono, aços comuns, etc). Não é indicado para usinagem de cobre e suas ligas, pois esta ação química gera mancha superficial (RUFFINO, 1977);

- óleos minerais clorados-sulfurados (ativo): contém até 3\% de enxofre e até $1 \%$ de cloro, confere superior qualidade anti-soldante em relação ao anterior. $\mathrm{O}$ aditivo 
cloro estende os beneficios anti-soldante e extrema pressão para temperaturas mais baixas. Recomendado para uso em usinagem de aços resistentes de baixo carbono e também ligas de cromo-níquel (RUFFINO, 1977).

b) Óleos Graxos (inativo):

Muito usado no passado, mas seu emprego é restrito devido ao alto custo (RUFFINO, 1977) e pelo fato de se tornarem viscosos e se deteriorarem com o tempo, tem sido largamente substituídos pelos óleos compostos ou pelos óleos EP (DINIZ et al., 1999). São óleos de origem vegetal e animal (DINIZ et al., 1999). Os óleos graxos mais usados são: óleo de toicinho e de baleia (RUFFINO, 1977). Suas propriedades são: boa capacidade de molhar o material da peça e ferramenta, média capacidade de refrigeração, boa capacidade lubrificante, facilitam a obtenção de peças com bom acabamento, mas suas propriedades anti-soldantes são fracas (DINIZ et al., 1999). Usados nas operações severas de usinagem de ligas não-ferrosas tenazes, onde o uso de óleos sulfurados produz manchas indesejadas (RUFFINO, 1977).

c) Óleos Compostos (vantagens dos óleos graxos e maior estabilidade química - não se deterioram ou se tornam mais viscoso com o tempo (DINIZ et al., 1999)):

- compostos de óleo mineral e óleo graxo (inativo): cưiuinação de um ou mais óleos graxos (usualmente óleo de toicinho) com óleos minerais puros. As gorduras conferem ao óleo mineral melhor molhabilidade e melhor penetrabilidade, resulta em melhor acabamento superficial da peça usinada. Recomendado para usinagens não muitos severas em máquinas operatrizes automáticas (bom acabamento superficial e precisão), usinagens do cobre e suas ligas (não corrosivo tanto para materiais ferrosos e não-ferrosos) e substitui os óleos sulfurados ou sulfuradosclorados nos casos de usinagem de peças que devem ser submetidas à têmpera subseqüente (pois o enxofre prejudica a têmpera) (RUFFINO, 1977);

- compostos de óleos minerais e óleos graxos sulfurados: são inativos, mas acima de $370{ }^{\circ} \mathrm{C}$ e sob as condições de pressão na interface ferramenta-cavaco tornam ativos. Recomendado na usinagem de metais não-ferrosos (especialmente onde deseja bom acabamento superficial), usinagens onde as pressões de corte são altas e onde a vibração da ferramenta tende a se tornar excessiva (devido às características anti-soldantes e alto poder lubrificante), usados em máquinas que usinam ora metais ferrosos ora não-ferrosos e em algumas máquinas especiais com tripla função (fluido de corte, lubrificante e fluido hidráulico) (RUFFINO, 1977); 
- compostos de óleos minerais e óleos graxos sulfurados-clorados: o aditivo cloro confere qualidade de extrema pressão ao óleo, melhora o desempenho anti-soldante em temperaturas e pressões mais baixas (RUFFINO, 1977);

- compostos de óleos graxos sulfurados ou clorados-sulfurados (ativo): devido à presença de gorduras, contem mais enxofre do que os outros compostos e são muito mais ativos a temperaturas mais baixas do que os óleos do tipo inativo. É o fluido de corte mais efetivo para uma variedade muito grande de operações de usinagens (particularmente em condições severas) devido a sua alta oleosidade e alta capacidade de extrema pressão (RUFFINO, 1977).

2.3) FLUIDOS DE CORTE QUÍMICOS (fluidos sintéticos): têm a estrutura molecular controlada (NACHTMAN, 1989) e apresentam-se sob a forma de soluções verdadeiras ou soluções coloidais extremamente finas. Possui características de fluido refrigerante e alguns apresentam poder lubrificante, não contém óleo mineral em sua composição e são constituídos de agentes químicos em água (RUFFINO, 1977):

- aminas e nitritos: para impedir a corrosão;

- nitratos: para a estabilização dos nitritos;

- fosfatos e boratos: para baixar a dureza da água;

- sabões e agentes de molhabilidade: para lubrificação e diminuição da tensão superficial;

- compostos de enxofre, cloro e fósforo: para lubrificação química;

- glicóis: para agente aglomerante e umidificante e

- germicidas: para controlar a proliferação de bactérias.

2.4) MERCÚRIO: meio lubrificante a baixas velocidades de corte, reage com a superfície nascente do cavaco e produz um amálgama, de baixa tensão de cisalhamento, impede o contato ferramenta-cavaco, tendo eficiência notável para impedir a formação da aresta postiça de corte (RUFFINO, 1977).

\section{3 - Fluidos de corte gasosos}

Os gases utilizados visam principalmente a refrigeração (ação física) no processo de usinagem, mas apresentam ainda as ações químicas e mecânicas:

- ação física: refrigera a ferramenta, peça ou as partes ligadas ao processo de usinagem, sendo esta refrigeração não tão efetiva quanto à dos líquidos, devido à baixa capacidade 
calorifica dos gases. Compensa-se utilizando altas pressões, altas velocidades e baixas temperaturas (RUFFINO, 1977);

- ação química: quando os elementos contidos nos gases e na superfície nascente do cavaco reagem produzindo um composto que se interpõe ao cavaco e superfície de saída da ferramenta (RUFFINO, 1977).

Por exemplo (RUFFINO, 1977): o oxigênio reage com a superfície nascente do cavaco de materiais ferrosos e produz instantaneamente um óxido de ferro depositado em fina camada sobre a superfície de saída da ferramenta. Distinguem duas formações, que dependem das concentrações de oxigênio no fluido:

- $\mathrm{Fe}_{3} \mathrm{O}_{4}$ (óxido preto): comporta como bom lubrificante sólido e

- $\mathrm{Fe}_{2} \mathrm{O}_{3}$ (óxido vermelho): comporta mais como abrasivo do que como lubrificante.

Portanto segundo RUFFINO (1977), as mais baixas concentrações de oxigênio dariam, como resultado, menor atrito no processo.

- ação mecânica: expulsa o cavaco da região de corte.

A penetração dos gases se faz da mesma forma que a dos líquidos, porém mais facilmente. O jato é dirigido na região da interface com alta pressão (RUFFINO, 1977).

Consideram-se fluidos de corte gasosos todos os fluidos que ao saírem do duto de aplicação para a região do corte estão em fase gasosa (RUFFINO, 1977). Pode-se destacar os seguintes fluidos de corte gasosos:

a) $\mathrm{Ar}$

Apresenta pequena capacidade de refrigeração em comparação com fluidos de corte líquidos (DINIZ te al., 1999) (RUFFINO, 1977). Entretanto segundo RUFFINO (1977), aplicando sob pressão e temperatura abaixo de $0{ }^{\circ} \mathrm{C}$, a vida da ferramenta aumenta consideravelmente. Para DINIZ et al. (1999) é muito empregado na usinagem a seco do ferro fundido cinzento, pois quando utiliza fluido de corte líquido, os minúsculos cavacos formados são conduzidos pelo líquido às partes de atrito da máquina-ferramenta, danificando-as.

Uma técnica que está sendo usada, é a refrigeração com ar resfriado $\left(-30^{\circ} \mathrm{C}\right)$. Sendo que esta refrigeração em todas as velocidades de corte e métodos de usinagem, não apresenta grande efeito sobre a vida útil das ferramentas. Esse efeito aparece somente sob condições em que o desenvolvimento de calor causado pela remoção de cavacos é evitado durante um tempo determinado (NAKAGAWA, 2000).

Segundo NAKAGAWA (2000), os mais recentes resultados mostram que a remoção de cavacos com ar resfriado ainda não têm uma fundamentação firme. 
Para NAKAGAWA (2000) existe uma grande quantidade de obstáculos que devem ser vencidos até a efetivação comercial desta técnica, tais como, custo/eficiência (custo de energia do compressor e do refrigerador, por exemplo).

b) Dióxido de carbono $\left(\mathrm{CO}_{2}\right)$

Até a temperatura de $-78^{\circ} \mathrm{C}$ (ponto de sublimação), o $\mathrm{CO}_{2}$ apresenta-se como um refrigerante de ação rápida, capaz de extrair grande parte do calor gerado no processo de usinagem, consegue-se aumento da vida da ferramenta (RUFFINO, 1977). A direção do jato é bastante importante, deve ser dirigido à ponta da ferramenta e algumas vezes à peça em usinagem, mas nunca sobre o cavaco (RUFFINO, 1977). Porém o custo de $\mathrm{CO}_{2}$ é muito alto, portanto, seu emprego só é justificado economicamente em operações que requerem altas velocidades de corte e grande remoção de material (RUFFINO, 1977).

c) Outros gases

- Nitrogênio: resultados positivos em operações de torneamento e outras operações realizadas com ferramentas de corte. Porém em operações com ferramentas abrasivas ocorre aumento das forças de corte, devido à falta de oxigênio, não formando óxido de ferro sobre a ferramenta (RUFFINO, 1977);

- Trifluorobromometana: é um fluorocarboneto gasoso que apresenta uma ação efetiva em uma larga faixa de velocidade de corte. A aplicação através de um jato sobre a superfície de incidência da ferramenta demonstra uma melhora sensível na vida da ferramenta (RUFFINO, 1977). 


\section{BIBLIIOGRAFIA}

AGOSTINHO, O.L.; RODRIGUES, A.C.S.; LIRANI, J. (1977). Tolerâncias, ajustes, desvios e análise de dimensões. São Paulo, Edgard Blücher.

AMERICAN SOCIETY FOR METALS (1978). Metals Handbook. 9.ed. Metals Park, Ohio. $1 \mathrm{v}$, p.11-32.

AMERICAN SOCIETY FOR METALS (1989a). Metals Handbook. 9.ed. Metals Park, Ohio. 16v, p.597-609.

AMERICAN SOCIETY FOR METALS (1989b). Metals Handbook. 9.ed. Metals Park, Ohio. 16v, p.648-665.

ANGUS, H.T. (1976). Cast Iron: Physical and Engineering Properties. 2.ed. London, Butterworths.

ASSOCIAÇÃO BRASILEIRA DE NORMAS TÉCNICAS (1984). NBR 8404 - Indicação do estado de superficies em desenhos técnicos. Rio de Janeiro.

ASSOCIAÇÃO BRASILEIRA DE NORMAS TÉCNICAS (1989). NBR 6162 - Movimentos e relações geométricas na usinagem dos metais. Rio de Janeiro.

ASSOCIAÇÃO BRASILEIRA DE NORMAS TÉCNICAS (1990). NBR 6163 - Geometria da cunha de corte. Rio de Janeiro.

BAUMGARTEN, J.F. (1988). Aplicação e desenvolvimento da cerâmica avançada. Máquinas e Metais, n.265, p.51-56, jan.-fev.

BHATTACHARYYA, S.K.; EZUGWU, E.O.; JAWAID, A. (1989). Performance of ceramic tool materials for the machining of cast iron. Wear, v.135, n.1, p.147-159, Dec.

BOEHS, L.; AGUIAR, C.G.; FERREIRA, J.C. (2000). A usinagem do ferro fundido nodular de fundição contínua. Máquinas e Metais, n.414, p.58-72, jul. 
BRESCIANI FILHO, E. (1988). Seleção de materiais metálicos. 2.ed. Campinas, Editora da UNICAMP.

BRESCIANI FILHO, E.; ZAVAGLIA, C.A.C.; NERY, F.A.C.; BOTTON, S.T. (1986). Conformação Plástica dos Metais Volume I. 3.ed. Campinas, Editora da UNICAMP.

BUGAUD, J.P. (2000). Integração de centros de usinagem. Máquinas e Metais, n.414, p.3440, jul.

BURGES, W.A. (1997). Identificação de possiveis riscos à saúde do trabalhador. Editora Ergo.

BYRNE, G.; HEINZL, J.; BARRY, J.; EITZENBERGER, H. (1997). Chip root tests using PCD and MCD cutting tools. Industrial Diamond Review, n.3, p.96-101.

CARPINETTI, L.C.R. (2000). Planejamento e análise de experimentos. São Carlos, EESC, jan.

CENTRE TECHNIQUE DES INDUSTRIES MECANIQUES (1999). A micropulverização posta à prova. Máquinas e Metais, n.405, p.64-69, out.

CHIAVERINI, V. (1984). Aços e Ferros Fundidos. 5.ed. São Paulo, Associação Brasileira de Metais.

COLPAERT, H. (1974). Metalografia dos produtos siderúrgicos comuns. 3.ed. São Paulo, Edgard Blücher.

D'ERRICO, G.E.; CALZAVARINI, R.; CHIARA, R.; MORRELL, R.; LAY, L.A. (1997). Performance of ceramic cutting tools in turning operations. Industrial Ceramics, v.17, n.2, p.80-83, May-Aug.

DeBENEDICTIS, K. (1997). A Short course in cast-iron turning. Manufacturing Engineering, v.119, n.3, p.48-54, Sep. 
DEONISIO, C.C.C.; NEVES, D.; KRABBE, D.F.M.; OTTA, R.M. (2000). Usinagem de ferro fundido na faixa de transição e em HSC. Máquinas e Metais, n.416, p.56-71, set.

DINIZ, A.E.; MARCONDES, F.C.; COPPINI, N.L. (1999). Tecnologia da usinagem dos materiais. São Paulo, MM Editora.

DIXON, G.; WRIGHT, R.N. (1985). Processes involved in the wear of cemented carbide tools. Wear, v.104, p.157-171.

EKSTRÖM, T. (1989). Effect of composition, phase content and microstructure on the performance of yttrium Si-Al-O-N ceramics. Materials Science and Engineering A: Structural Materials: Properties, Microstructure and Processing, v.A109, n.1-2, p.341349, Mar.

ENDLER, I.; WOLF, E.; LEONHARDT, A.; BEGER, A.; RICHTER, R. (1994). Preparation, characterization and wear behavior of $\mathrm{TiN}_{\mathrm{x}}$ - coated cermets obtained by plasma-enhanced chemical vapour deposition. Journal of Materials Science, v.29, n.23, p.6097-6103, Dec.

EZUGWU, E.O.; ARTHUR, S.J.; HINES, E.L. (1995). Tool-wear prediction using artificial neural networks. Journal of Materials Processing Technology, v.49, n.3-4, p.255-264, Feb.

EZUGWU, E.O.; LEONG, V.K. (1996). Surface abuse associated with finish turning of gray cast iron with ceramic tools. Tribology Transactions, v.39, n.2, p.362-367.

EZUGWU, E.O.; TANG, S.H. (1995). Surface abuse when machining cast iron (G-17) and nickel-base superalloy (Inconel 718) with ceramic tolls. Journal of Materials Processing Technology, v.55, n.2, p.63-69, Nov.

FERRARESI, D. (1977). Fundamentos da usinagem dos metais. São Paulo, Edgard Blücher.

FIELD, M.; KAHLES, J.F.; KOSTER, W.P. (1989). Surface finish and surface integrity. In: AMERICAN SOCIETY FOR METALS. Metals Handbook. 9.ed. Metals Park, Ohio. v. 16, p. 19-36. 
GARIBOV, V.R.; RYNSKOV, E.V. (1990). Experience and problems with the use of tools made of superhard materials and ceramics in the auto industry. Soviet Engineering Research, v.10, n.10, p.85-87.

GERDES, T.; WILLERT-PORADA, M.; RODIGER, R. (1996). Microwave sintering of tungsten carbide cobalt hardmetals. Microwave Processing of Materials V Materials Research Society Symposium Proceedings. v.430, p.45-50.

GNESIN, G.G.; YAROSHENKO, V.P. (1994). Structure and characteristics of $\mathrm{Si}_{3} \mathrm{~N}_{4}$ - based ceramic cutting tools. Key Engineering materials, v.89-91, p.737-742.

GRAHAM, D.E. (1994). Revestimentos de $\mathrm{Al}_{2} \mathrm{O}_{3}$ para ferramentas de carbeto cementado. Máquinas e Metais, n.345, p.22-35, out.

GRUSS, W.W. (1989). Cermets. In: AMERICAN SOCIETY FOR METALS. Metals Handbook. 9.ed. Metals Park, Ohio. v.16, p.90-104.

HEATH, P.J. (1989). Ultrahard tool materials. In: AMERICAN SOCIETY FOR METALS. Metals Handbook. 9.ed. Metals Park, Ohio. v.16, p.105-117.

HEISEL, U.; LUTZ, M.; SPATH, D.; WASMER, R.; WALTER, U. (1998). A técnica da quantidade mínima de fluidos e sua aplicação nos processos de corte. Máquinas $e$ Metais, n.385, p.22-38, fev.

HUSTON, M.F.; KNOBELOCH, G.W.; HYATT, G.L. (1998). Global trends in technology and markets. http://www.kennametal.com/library/technicalArticles/gtitm.html. (02 May 2000).

JINDAL, P.C.; SANTHANAM, A.T.; SCHLEINKOFER, U.; SHUSTER, A.F.; MARSH, B.K. (1999). PVD coatings for turning. http://www.kennametal.com/library/ technicalArticles/PVDcoatings.html. (02 May 2000).

KATBI, K. (1996). Um guia básico, para facilitar o processo de seleção de pastilhas de usinagem. Máquinas e Metais, n.362, p.42-50, mar. 
KATSUMURA, Y.; FUKATSU, T.; KOBAYASHI, M. (1993). Effects of TiC content and grain size on cutting performance of $\mathrm{Al}_{2} \mathrm{O}_{3}$-TiC ceramic tools. Tribology Transactions, v.36, n.1, p.43-48, Jan.

KATSUMURA, Y.; SOBATA, K.; UEHARA, Y.; SUZUKI, H. (1989). Effects of grain size on cutting performance of $\mathrm{Al}_{2} \mathrm{O}_{3}$-TiC ceramics tool. Journal of the Japan Society of Powder and Powder Metallurgy, v.36, n.8, p.903-907, Dec. / Resumo em Compendex Plus, 1990, Ref.05328799/

KENDALL, L.A. (1989). Tool wear and tool life. In: AMERICAN SOCIETY FOR METALS. Metals Handbook. 9.ed. Metals Park, Ohio. v.16, p.37-48.

KLEIN, M. (1961). Introduccion em las normas DIN. Berlin, Editorial Balzola-Bilbao.

KLIMENKO, S.A.; MUKOVOZ, Y.A.; LYASHKO, V.A.; VASHCHENKO, A.N.; OGORODNIK, V.V. (1992). On the wear mechanism of cubic boron nitride base cutting tools. Wear, v.157, n.1, p.1-7, Aug.

KOELSCH, J.R. (2000). Ferramentas de carbeto... o estado-da-arte. Máquinas e Metais, n.415, p.186-201, ago.

KOMANDURI, R.; SAMANTA, S.K. (1989). Ceramics. In: AMERICAN SOCIETY FOR METALS. Metals Handbook. 9.ed. Metals Park, Ohio. v.16, p.98-104.

KÖNIG, W.; NEISES, A. (1993). Wear mechanisms of ultrahard, non-metallic cutting materials. Wear, v.162-164, p.12-21.

KONYASHIN, I.Y. (1996). Chemical vapor deposition of thin coatings onto $\mathrm{Al}_{2} \mathrm{O}_{3}$ indexable cutting inserts. Surface and Coatings Technology, v.85, n.3, p.131-137, Nov.

LIM, S.C.; LIM, C.Y.H.; LEE, K.S. (1995). The effects of machining conditions on the flank wear of TiN-coated high speed steel tool inserts. Wear, v.181-183, n.2, p.901-912, Mar.

LO CASTO, S.; LO VALVO, E.; RUISI, V.F.; LUCCHINI, E.; MASCHIO, S. (1993). Wear mechanism of ceramics tools. Wear, v.160, n.2, p.227-235. Feb. 
MACHADO, Á.R. (1988). A evolução dos materiais para ferramentas de corte. Máquinas $e$ Metais, n.265, p.92-97, jan.-fev.

MARCONDES, F.M. (1990). A história do metal duro. SANDVIK Coromant, mar.

MEHROTRA, P.K. (1998). Applications of ceramic cutting tools. Key Engineering Materials, v.138-140, p.1-24.

MILLS, B.; REDFORD, A.H. (1983). Machinability of engineering materials. Applied Science Publishers, England, p.13-21.

NACHTMAN, E.S. (1989). Metal cutting and grinding fluids. In: AMERICAN SOCIETY FOR METALS. Metals Handbook. 9.ed. Metals Park, Ohio. v.16, p.121-132.

NAKAGAWA, H. (2000). Mínima quantidade de lubrificação não agride o meio ambiente. Máquinas e Metais, n.415, p.40-49, ago.

NARUTAKI, N.; YAMANE, Y.; TASHIMA S.; KUROKI, H. (1997). A new advanced ceramic for dry machining. CIRP Annals Manufacturing Technology, v.46, n. 1, p.43-46.

NOVASKI, O.; DÖRR, J. (1999). Usinagem quase a seco. Máquinas e Metais, n.406, p.3441 , nov.

OGASAWARA, T.; OTANI, K.; SHICHI, Y.; YAMANAKA, J. (1999). Surface analysis of silicon nitride cutting tool after turning gray cast iron. Journal of the Ceramic Society of Japan, v.107, n.1246, p.497-501 /Resumo em EI Compendex, 1999, Ref.09145400/

OLIVEIRA, J.F.G. (1998). Tópicos avançados sobre o processo de retificação. São Carlos, EESC, set.

PEYRE, J.P.; DUCHATEAU, D. (1995). As perspectivas são de uma grande evolução dos revestimentos PVD e CVD. Máquinas e Metais, n.351, p.42-50, abr.

PEYRE, J.P.; VINTERHOLLER, O. (1994). Revestimento por CVD ou PVD, as ferramentas têm vida melhor. Máquinas e Metais, n.344, p.68-79, set. 
PIMENTEL, C.A.F.; RABINOVICH, S.V.; YAMAMURA, P. (1987). Elementos da teoria de erros. São Paulo, Instituto de Física da USP.

RICHTER, V.; BEGER, A.; DROBNIEWSKI, J.; ENDLER, I.; WOLF, E. (1996). Characterisation and wear behaviour of TiN and $\mathrm{TiC}_{\mathrm{x}} \mathrm{N}_{1-\mathrm{x}}-$ coated cermets. Materials Science and Engineering, v.209, n.1-2, p.353-357, May.

ROTBERG, J.; SHOVAL, S.; BER, A. (1997). Tool wear monitoring in high speed machining with silicon-nitride tool. Manufacturing System, v.26, n.4, p.221-227.

RUFFINO, R.T. (1977). Fluidos de corte. In: Fundamentos da usinagem dos metais, São Paulo, Edgard Blücher, p.512-565.

SAHM, D.; SCHNEIDER, T. (1996). A produção sem refrigerante é interessante e deve ser mais conhecida. Máquinas e Metais, n.367, p.38-55, ago.

SAMOILOV, V.S. (1990). Use of cutting tools equipped with cutting ceramic during turning. Soviet Engineering Research, v.10, n.10, p.88-90.

SANTHANAM, A.T.; TIERNEY, P. (1989). Cemented carbides. In: AMERICAN SOCIETY FOR METALS. Metals Handbook. 9.ed. Metals Park, Ohio. v.16, p. 71-89.

SCHULZ, H. (1997). Start of art and trends of high speed machining. $2^{\circ}$ Seminário Internacional de Alta Tecnologia - Usinagem com Altíssima Velocidade de Corte e Alta Precisão. UNIMEP. July.

SCHULZ, H.; EMRICH, A.K.; FINZER, T.; DÖRR, J. (2000). Quais são e para que servem os revestimentos. Máquinas e Metais, n.416, p.38-45, set.

SIGL, L.S.; SCHWETZ, K.A.; DWORAK, U. (1994). Continuous turning with $\mathrm{TiB}_{2}$ cermets: preliminary cutting tests. International Journal of Refractory Metals and Hard Materials, v.12, n.2, p.95-99. 
SILVA, R.F.; OLIVEIRA, F.J.; CASTRO, F.P.; VIEIRA, J.M. (1998). Modeling of chemical wear in ferrous alloys/silicon nitride contacts during high speed cutting. Acta Materialia, v.46, n.7, p.2501-2507, Apr.

TAKAHASHI, T. (1998). Development of fine and high strength $\mathrm{Al}_{2} \mathrm{O}_{3}$ based ceramics. Journal of the Japan Society of Powder and Powder Metallurgy, v.45, n.6, p.499-506, Jun. / Resumo em EI Compendex, 1998, Ref.05328799/

TAKATSU, S. (1990). Recent developments in hard cutting tool materials. High Temperature Materials and Process, v.9, n.2-4, p.175-193.

TEETER, F.J. (1994). As ferramentas revestidas com TiN trazem muitos beneficios. Máquinas e Metais, n.342, p.16-24, jul.

THOMPSON, D.C.; CHRISLOCK, J.L.; NEWTON, L.E. (1982). Development of an inexpensive, high-accuracy diamond turning machine. Precision Engineering, v.4, n.2, p.73-77, Apr.

TOMITA, K. (1999). O atual estágio da HSM e dos materiais de ferramentas de corte. Máquinas e Metais, n.405, p.20-39, out.

TÖNSHOFF, H.K.; WOBKER, H.G. (1991). Influence of surface integrity on the wear of ceramics cutting tools. Lubrication Engineering, v.47, n.7, p.579-583, Jul.

TRENT, E.M. (1991). Metal Cutting. 3.ed. England, Butterworth Heinemann.

VASILASH, G.S. (1996). Superhard coatings: more than meets the eye. http://www.kennametal.com/library/technicalArticles/prod_1.htm. (02 May 2000).

VLEUGELS, J.; VAN DER BIEST, O. (1998). Chemical interaction between sialon ceramics and iron-based alloys. Key Engineering Materials, v.138-140, p.127-176.

VOIGT, R.C. (1999). Cast iron graphite shape, fine structure, keys to cheaper, faster machining. http://www.engr.psu.edu/publications/News/1999\%20Press\%20Releases/ May/voight.html. (08 Mar. 2000). 
YAMANE, Y.; USUKI, H.; YAN, B.; NARUTAKI, N. (1990). The formation of a protective oxide layer in machining resulphurized free-cutting steels and cast irons. Wear, v.139, n.2, p.195-208, Aug.

ZHOU, L.Y.; YANG, G.Y.; YU, Q.X. (1988). Turning of heat treated steels with CVD coated carbide tools. Werkstatt Betr., v.121, n.2, p.147-148, Feb. / Resumo em Compendex Plus, 1988, Ref.00432792/

ZLENKO, N.I.; SEMENTSOV, V.I.; KNYAZEV, P.V. (1990). Performance of inserts made of tomal-10 during machining of cast iron. Soviet Engineering Research, v.10, n.10, p.98-99. 


\section{BIBBLIOGRAFIA COMPLEMENTAR}

BEARD, T. Are you turning fast enough? http://www.mmsonline.com/articles/099802.html. (14 Feb. 2000).

GRAHAM, D. Incremental improvements in coated carbide cutting tools add up to important gains in consistency and reliability. http://www.mfginfo.com/htm/carbide.htm. (09 Mar. 2000).

HUDDLE, D. Extending the range of PCBN. http://www.mmsonline.com/articles/ 019902.html. (14 Feb. 2000).

KÖNIG, W.; NEISES, A. (1993). Wear mechanism of ultrahard, non-metallic cutting materials. Wear, v.162-164, p.12-21.

NISHIKAWA, T.; KAWAKITA, T. (1986). Reactions which take place at the boundary between molten cast-iron and diamond. Bulletin of the Japan Society of Precision Engineering, v.20, n.2, p.125-126, Jun.

QI, H.S.; MILLS, B. (1996). On the formation mechanism of adherent layers on a cutting tool. Wear, v.198, n.1-2, p.192-196, Oct.

QUINTO, D.T. (1996). Cutting tools. http://www.kennametal.com/library/technicalArticles/ tp_1.htm. (02 May 2000).

SANDVIK COROMANT (2000). Ferramentas para torneamento. /Catálogo/ 


\section{APÊNDICE I - Vantagens e desvantagens dos processos CVD e PVD}

Tabela 13 - Vantagens e desvantagens do processo CVD (PEYRE \& VINTERHOLLER, 1994)

\begin{tabular}{|c|c|}
\hline \multicolumn{2}{|c|}{ PROCESSO CVD } \\
\hline VANTAGENS & DESVANTAGENS \\
\hline $\begin{array}{l}\text { - Deposição de numerosos componentes } \\
\text { (TiC, TiN, TiCN); } \\
\text { - Possibilidade de realizar multicamadas } \\
\text { (TiC + TiN; TiC + TiCN + TiN); } \\
\text { - Bom poder de penetração, possibilidade } \\
\text { de revestir ferramentas de formas } \\
\text { complexas; } \\
\text { - Espessura uniforme do depósito; } \\
\text { - Depósitos aderentes e densos; } \\
\text { - Controle da espessura do depósito. }\end{array}$ & $\begin{array}{l}\text { - Dificilmente aplicável às ferramentas de } \\
\text { aço rápido; } \\
\text { - Obrigatório abrandar as arestas para } \\
\text { diminuir sua fragilidade; } \\
\text { - Tratamento que necessita de novas } \\
\text { têmperas sob vácuo (aço rápido); } \\
\text { - Diminuição da tenacidade das } \\
\text { ferramentas; } \\
\text { - Tensões residuais podendo ser de tração. }\end{array}$ \\
\hline
\end{tabular}

Tabela 14 - Vantagens e desvantagens do processo PVD (PEYRE \& VINTERHOLLER, 1994)

\begin{tabular}{|c|c|}
\hline \multicolumn{2}{|c|}{ PROCESSO PVD } \\
\hline VANTAGENS & DESVANTAGENS \\
\hline $\begin{array}{l}\text { - Tratamento em baixa temperatura; } \\
\text { - Possibilidade de recorrer a numerosos } \\
\text { componentes (TiC, TiN, TiCN, TiAlN, } \\
\text { CrN); } \\
\text { - Elevada velocidade de deposição; } \\
\text { - Boa condição da superfície dos } \\
\text { depósitos; } \\
\text { - Não há diminuição da tenacidade do } \\
\text { substrato; } \\
\text { - Conservação das arestas vivas; } \\
\text { - Tensões residuais do depósito em } \\
\text { compressão. }\end{array}$ & $\begin{array}{l}\text { - Aderência mais fraca do depósito, em } \\
\text { comparação com CVD; } \\
\text { - Pequena espessura dos depósitos (cerca } \\
\text { de } 3 \mu \mathrm{m} \text { ); } \\
\text { - Custo elevado; } \\
\text { - Obrigatório revestir por famílias de peças } \\
\text { de dimensões parecidas. }\end{array}$ \\
\hline
\end{tabular}




\section{APÊNIDICE III - Cálculo teórico da rugosidade Ra ideal}

\section{CÁLCULO TEÓRICO DO MENOR VALOR DE RUGOSIDADE SUPERFICIAL MÉDIA Ra IDEAL POSSÍVEL EM TORNEAMENTO}

Na bibliografia básica encontra-se uma fórmula simplificada da Rugosidade Total Rt $\left(\mathrm{Rt}=\mathrm{f}^{2} / 8 \mathrm{r}_{\varepsilon}\right)$, mas esta rugosidade é pouca usada fora da Alemanha. O parâmetro de rugosidade mais utilizado é a Rugosidade Média Aritmética Ra.

De forma semelhante como se define Rt, neste apêndice apresenta-se uma equação para a rugosidade $\mathrm{Ra}$ ideal, definida através da geometria dos parâmetros $\mathrm{f}$ e $\mathrm{r}_{\varepsilon}$. Esta equação é de grande contribuição para comparações entre a rugosidade ideal e atual.

Segundo AGOSTINHO et al. (1977), a rugosidade média aritmética Ra pode ser expressa matematicamente como:

$$
\mathrm{Ra}=\frac{\mathrm{A}}{\mathrm{L}}
$$

onde:

A: área total dos picos e vales dentro de um comprimento $\mathrm{L}$

L: comprimento de amostragem

Através de relações geométricas, dos valores de raio de ponta da ferramenta $\left(r_{\varepsilon}\right)$ e avanço (f), desenvolve-se a equação exata de Ra em função de $\mathrm{r}_{\varepsilon}$ e $\mathrm{f}$, válida para $\mathrm{f} \leq 2 \mathrm{r}_{\varepsilon}$ :

$$
\mathrm{Ra}_{\text {ideal }}=\frac{2}{1000 \cdot \mathrm{f}} \cdot\left\{\mathrm{r}_{\varepsilon}{ }^{2} \cdot \arccos \left(\frac{\mathrm{r}_{\varepsilon}-\mathrm{y}}{\mathrm{r}_{\varepsilon}}\right)-\mathrm{r}_{\varepsilon} \cdot \operatorname{sen}\left[\arccos \left(\frac{\mathrm{r}_{\varepsilon}-\mathrm{y}}{\mathrm{r}_{\varepsilon}}\right)\right] \cdot\left(\mathrm{r}_{\varepsilon}-\mathrm{y}\right)\right\}(\mu \mathrm{m})
$$

Onde:

$r_{\varepsilon}:$ raio de ponta da ferramenta $(\mathrm{mm})$

$f:$ avanço (mm/volta)

$$
y=r_{\varepsilon}-\frac{1}{2} \cdot \sqrt{\left(r_{\varepsilon}{ }^{2}-\frac{f^{2}}{4}\right)}-\frac{r_{\varepsilon}^{2}}{f} \cdot \operatorname{arcsen}\left(\frac{f}{2 r_{\varepsilon}}\right)
$$


Devido à complexidade da equação exata anterior, encontra-se uma relação simplificada através de regressões de $2^{\circ}$ grau, válida mais precisamente para $\mathrm{Ra} \leq 5 \mu \mathrm{m}$ e para $0,4 \leq \mathrm{r}_{\varepsilon} \leq$ $2,0 \mathrm{~mm}$ :

$\left.\mathrm{Ra}_{\text {ideal }}\right|_{\text {simplificada }}=\frac{32,6016 \cdot \mathrm{f}^{2}-0,0928 . \mathrm{f}+0,0041}{\mathrm{r}_{\varepsilon}}(\mu \mathrm{m})$

$\mathrm{Na}$ Figura 48, tem-se um gráfico para encontrar o valor de Ra.

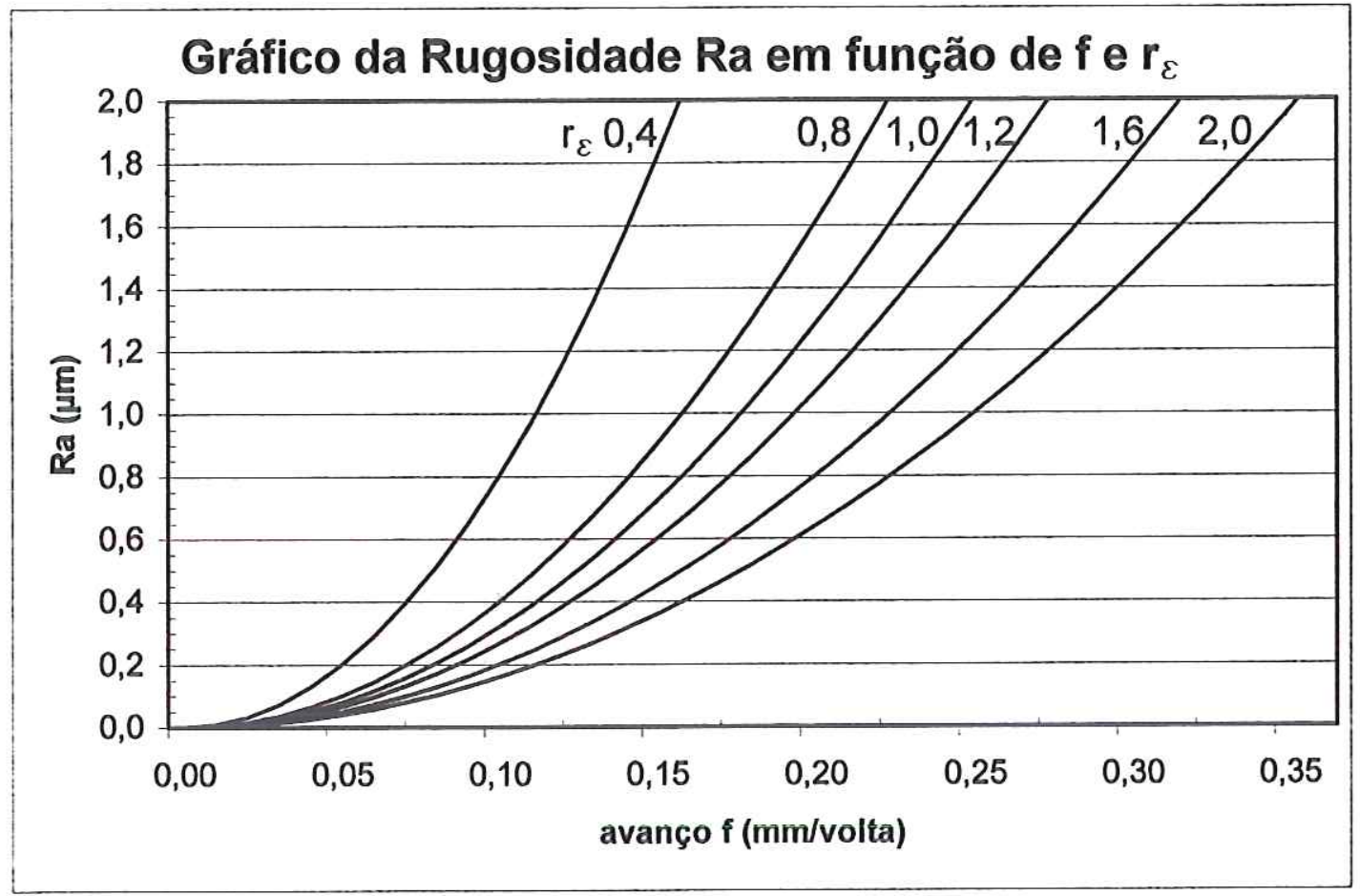

Figura 48 - Gráfico de Ra em função do avanço (f) e raio de ponta da ferramenta $\left(r_{\varepsilon}\right)$

AGOSTINHO et al. (1977) afirma que:

$2,00 \leq \frac{\mathrm{Rt}}{\mathrm{Ra}} \leq 4,00$

Pelas equações desenvolvidas, encontra-se uma relação mais estreita:

$2,285 \leq \frac{\mathrm{Rt}}{\mathrm{Ra}} \leq 3,897$ 

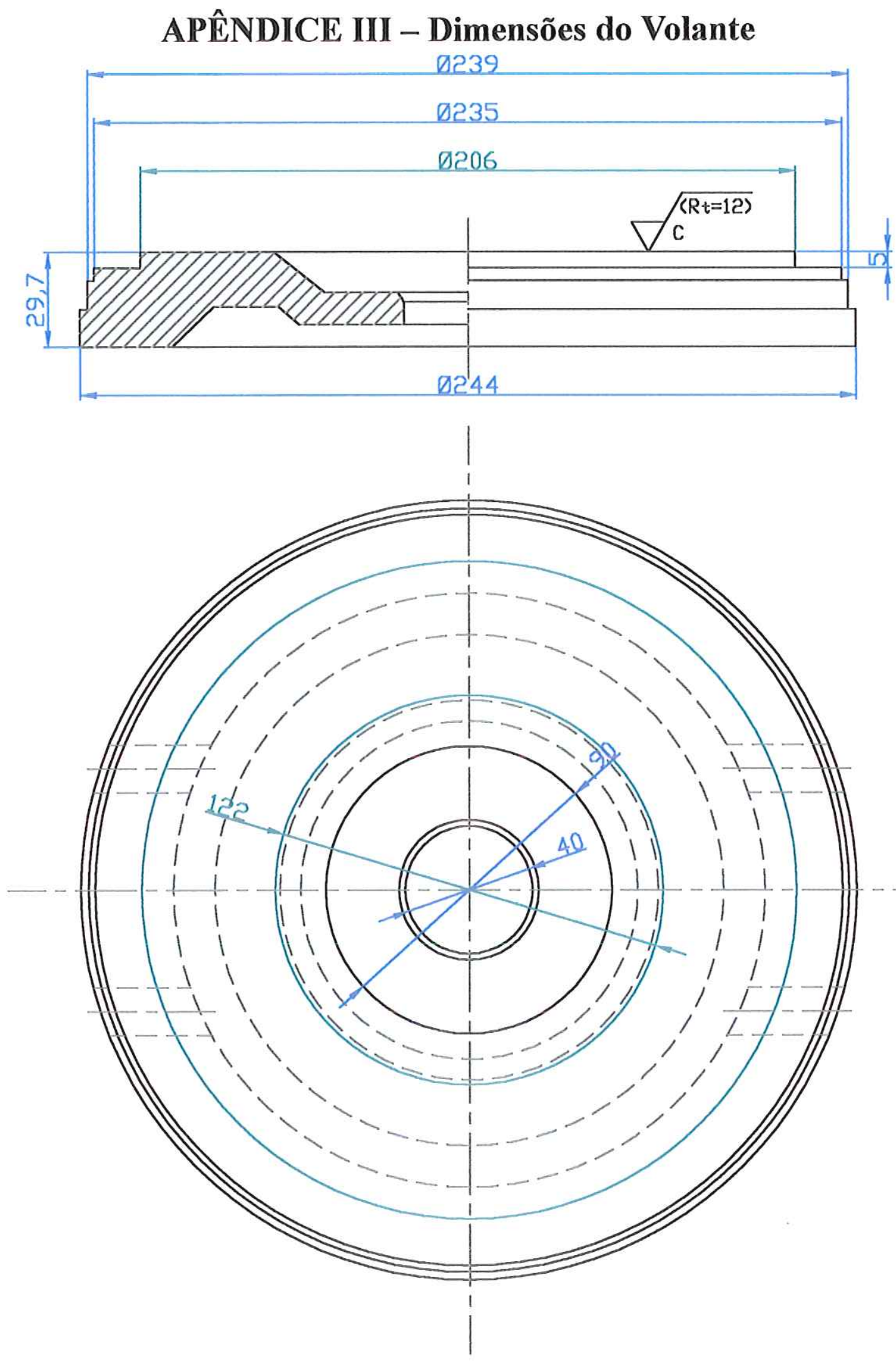

Figura 49 - Detalhes do volante de ferro fundido cinzento GG25 utilizado nos ensaios 


\section{APENDICE IV - Programa CNC}

Programa $\mathrm{CNC}$ de torneamento utilizado nos experimentos.

$\mathrm{n} 10 \mathrm{~g} 53 \mathrm{x} 300 \mathrm{z} 300 \mathrm{f} 1000$

t6 d1 g95

$\mathrm{m} 4 \mathrm{~s} 3000$

g96 s1350

LIMS $=5000$

TRANS z216.9

$\mathrm{g} 01 \mathrm{x} 212 \mathrm{z}=\mathrm{-R} 01 \mathrm{f} 0.5$

$\mathrm{x} 105 \mathrm{f} 0.08$

zl fl

g0 g53 x150 z300

m5

$\mathrm{m} 30$ 


\section{APÊNIDICIE $\mathbb{V}$ - Dimensões dos insertos e porta}

\section{ferramentas}

INSERTOS DE CERÂMICA

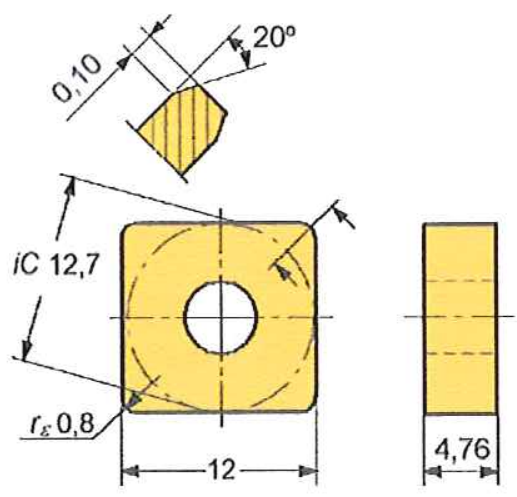

Figura 50 - Dimensões do inserto de Cerâmica CC 650 código SNGA 120408T01020 da Sandvik

\section{INSERTOS DE METAL DURO}

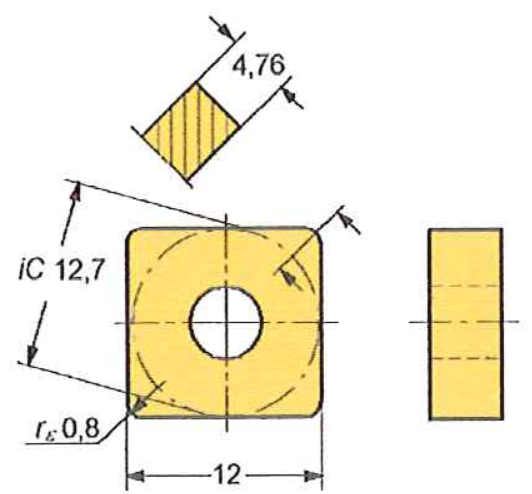

Figura 51 - Dimensões do inserto de Metal Duro GC 3015 código SNMA 120408-KR da Sandvik

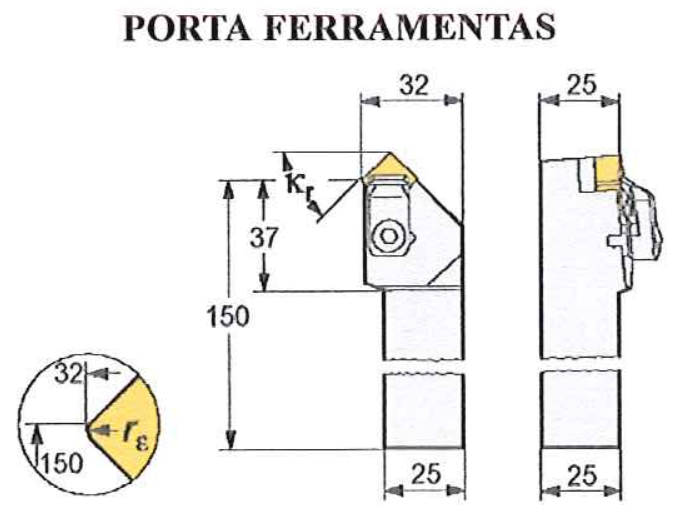

Figura 52 - Dimensões do porta ferramentas CSSNL-2525M-12IC da Sandvik 


\section{APÊNIDICE VII - Conversão de $L f$ para $L c$}

CONVERSÃo DE L $f$ PARA lc PARA SOMENTE UM PASSE DE FACEAMENTO

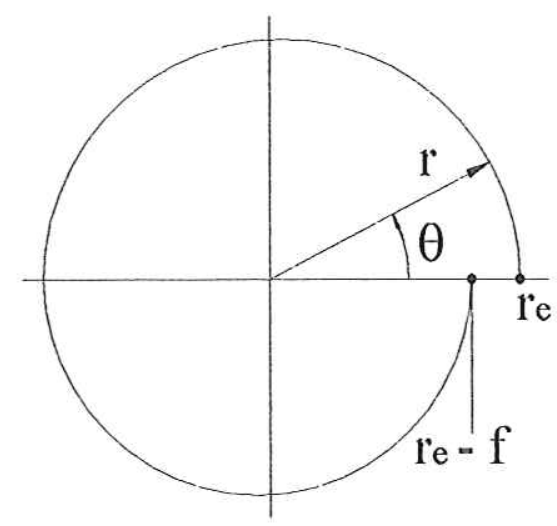

Variáveis:

- $r_{e}$ : raio maior da peça $(\mathrm{mm})$

- $\quad r_{i}$ : raio menor da peça $(\mathrm{mm})$

- $f$ : avanço (mm/volta)

- $\quad \theta$. ângulo (radianos)

- $n$ : rotações

- Lf: percurso de avanço (mm)

- Lc: percurso de corte $(\mathrm{km})$

$r=f(\theta)=r_{e}-\frac{f}{2 \pi} \theta$

$n=\frac{r_{e}-r}{f}$, onde $r_{i} \leq r \leq r_{e}$

$L c=\int_{\theta_{i}}^{\theta_{f}} f(\theta) d \theta=\int_{\theta_{i}}^{\theta_{f}}\left(r_{e}-\frac{f}{2 \pi} \theta\right) d \theta=\left[r_{e} \theta-\frac{f}{4 \pi} \theta^{2}\right]_{0}^{2 \pi\left(\frac{r_{e}-r}{f}\right)}$

$L c=r_{e}\left[2 \pi\left(\frac{r_{e}-r}{f}\right)\right]-\frac{f}{4 \pi}\left[2 \pi\left(\frac{r_{e}-r}{f}\right)\right]^{2}(\mathrm{~mm})$

$L f=r_{e}-r(\mathrm{~mm})$

Simplificando:

$L c=\frac{L f \cdot \pi}{f \cdot 10^{6}}\left(2 r_{e}-L f\right)(\mathrm{km})$ 
Tabela 15 - Tabela de conversão $\mathrm{L} f$ para $\mathrm{L} c$

\begin{tabular}{|c|c|c|c|}
\hline \multirow{2}{*}{ Passe } & \multirow{2}{*}{$\begin{array}{c}\mathbf{L f} \\
(\mathrm{mm})\end{array}$} & f $0,08 \mathrm{~mm} /$ volta & f $0,10 \mathrm{~mm} /$ volta \\
\hline & & $\mathbf{L c}(\mathrm{km})$ & $\mathbf{L c}(\mathrm{km})$ \\
\hline 1 & 42 & 0,270 & 0,216 \\
\hline 2 & 84 & 0,541 & 0,433 \\
\hline 3 & 126 & 0,811 & 0,649 \\
\hline 4 & 168 & 1,082 & 0,866 \\
\hline 5 & 210 & 1,352 & 1,082 \\
\hline 6 & 252 & 1,623 & 1,298 \\
\hline 7 & 294 & 1,893 & 1,515 \\
\hline 8 & 336 & 2,164 & 1,731 \\
\hline 9 & 378 & 2,434 & 1,948 \\
\hline 10 & 420 & 2,705 & 2,164 \\
\hline 11 & 462 & 2,975 & 2,380 \\
\hline 12 & 504 & 3,246 & 2,597 \\
\hline 13 & 546 & 3,516 & 2,813 \\
\hline 14 & 588 & 3,787 & 3,030 \\
\hline 15 & 630 & 4,057 & 3,246 \\
\hline 16 & 672 & 4,328 & 3,462 \\
\hline 17 & 714 & 4,598 & 3,679 \\
\hline 18 & 756 & 4,869 & 3,895 \\
\hline 19 & 798 & 5,139 & 4,111 \\
\hline 20 & 840 & 5,410 & 4,328 \\
\hline 21 & 882 & 5,680 & 4,544 \\
\hline 22 & 924 & 5,951 & 4,761 \\
\hline 23 & 966 & 6,221 & 4,977 \\
\hline 24 & 1008 & 6,492 & 5,193 \\
\hline 25 & 1050 & 6,762 & 5,410 \\
\hline 26 & 1092 & 7,033 & 5,626 \\
\hline 27 & 1134 & 7,303 & 5,843 \\
\hline 28 & 1176 & 7,574 & 6,059 \\
\hline 29 & 1218 & 7,844 & 6,275 \\
\hline 30 & 1260 & 8,115 & 6,492 \\
\hline 31 & 1302 & 8,385 & 6,708 \\
\hline 32 & 1344 & 8,656 & 6,925 \\
\hline 33 & 1386 & 8,926 & 7,141 \\
\hline 34 & 1428 & 9,197 & 7,357 \\
\hline 35 & 1470 & 9,467 & 7,574 \\
\hline 36 & 1512 & 9,738 & 7,790 \\
\hline
\end{tabular}




\section{APÊNDICE VIII - DADOS DO FABRICANTE DOS VOLANTES}

Neste item efetuam-se comparações com os dados industriais utilizados pela empresa fornecedora dos volantes, Auto Pira S/A Ind. e Comércio de Peças. Após desbaste com inserto de nitreto de silício, realiza-se um passe de acabamento, nas seguintes condições:

- Torno Cosmos 30U;

- Ferramenta: CNGA 120416 (cerâmica mista à base de alumina 70\% com carboneto de titânio 30\%, velocidade de corte máxima admissível $1200 \mathrm{~m} / \mathrm{min}$ );

- Velocidade de corte: $900 \mathrm{~m} / \mathrm{min}$ (constante);

- Avanço: 0,20 mm/volta;

- Profundidade de usinagem: $0,3 \mathrm{~mm}$;

- Lubrificação: a seco;

- Rugosidade desejada: Rt $12 \mu \mathrm{m}$;

- Critério de fim de vida das ferramentas: quando Rt atinge $12 \mu \mathrm{m}$;

- Vida aproximada da ferramenta: 80 peças por aresta.

Segundo equações do APÊNDICE II, Rt $12 \mu \mathrm{m}$ equivale a aproximadamente Ra 3,2 $\mu \mathrm{m}$ ou classe de rugosidade N8 (ABNT, 1984), que segundo FIELD et al. (1989), é acabamento semi-fino. As rugosidades ideais são:

- Ra ideal: $0,803 \mu \mathrm{m}$;

- Rt ideal: $3,122 \mu \mathrm{m}$. 